THEÓGENES SILVA DE OLIVEIRA

REFINO DE SILÍCIO POR

SOLIDIFICAÇÃO DIRECIONAL 
THEÓGENES SILVA DE OLIVEIRA

\section{REFINO DE SILÍCIO POR SOLIDIFICAÇÃO DIRECIONAL}

Dissertação apresentada à Escola Politécnica da Universidade de São Paulo para a obtenção do título de Mestre em Engenharia 


\section{REFINO DE SILÍCIO POR SOLIDIFICAÇÃO DIRECIONAL}

Dissertação apresentada à Escola Politécnica da Universidade de São Paulo para a obtenção do título de Mestre em Engenharia

Área de Concentração:

Engenharia Metalúrgica e de Materiais

Orientador:

Prof. Dr. Marcelo de Aquino Martorano - EPUSP

Co-orientador:

Dr. João Batista Ferreira Neto - IPT/SP 


\section{FICHA CATALOGRÁFICA}

Theógenes Silva de Oliveira

Refino de Silício por Solidificação Direcional / Theógenes

Silva de Oliveira - São Paulo, 2008.

$125 \mathrm{p}$.

Dissertação (Mestrado) - Escola Politécnica da Universidade de São Paulo. Departamento de Engenharia Metalúrgica e de Materiais

1. Fenômenos de Transporte. 2. Transformações de Fase. 3. Refino. 4. Silício

I.Universidade de São Paulo. Escola Politécnica. Departamento de Engenharia Metalúrgica e de Materiais II.T. 
Dedico este trabalho a Maria Aurimar da Silva e a Denise Carvalho da Silva por me ensinarem a lição mais importante que um ser humano pode aprender: 0 Verdadeiro Amor. 
Pra que DEUS O PAI viva em mim

E que Sua Vontade se faça em mim É preciso somente buscar Essa fonte que está a jorrar. E clamar cada dia por Seu poder Confiar nEle sem mais temer. Pra viver como Cristo viveu É preciso ser um em DEUS.

"Viver Como Cristo Viveu" Letra e Música: Guilherme Schlichting 


\section{AGRADECIMENTOS}

A DEUS por tudo aquilo que tem feito por mim. Pela forma com que tem me demonstrado seu cuidado e Amor Eterno. Pelas bênçãos a mim oferecidas. Por ter me amado sendo eu ainda um pecador e por ter "amado o mundo de tal maneira que deu Seu Filho Unigênito para que todo aquele que nEle crer não pereça mas tenha Vida Eterna".

À minha avó materna, Maria Aurimar da Silva, por ser um exemplo perfeito de dedicação, cuidado e carinho.

Aos meus pais, por me amarem, ainda que ao seu modo.

À minha irmã Claudia Tatiane, pelo apoio constante, pelo amor, carinho e admiração que sente por mim e por ser a pessoa mais linda que DEUS colocou em minha vida.

Ao Prof. Dr. Marcelo de Aquino Martorano pela orientação, dedicação e esforço. Por me aceitar como orientando e, acima de tudo, pela paciência nas minhas deficiências. Muito Obrigado.

Ao Dr. João Batista Ferreira Neto, meu também orientador, por tudo que me ensinou nesses três anos de excepcional orientação. Pelo prazer em me ensinar e pela capacidade de me criticar sem ferir. Muito Obrigado.

Ao Instituto de Pesquisas Tecnológicas do Estado de São Paulo, pela estrutura sem a qual não seria possível a realização desse trabalho.

À FAPESP, pelo financiamento através do projeto 03/14-118-01.

À Tomoe Oide Tsubaki e Denise Ferreira, por terem realizado uma das partes mais importantes desse trabalho: as análises químicas. Sem vocês esse trabalho não existiria. Muito Obrigado.

A João Pedro Vaals Tosetti, Claudia Regina Serantoni e Daniel Bourdon, por terem me ensinado a operar o forno de solidificação direcional e por terem me socorrido em meio aos muitos problemas operacionais.

A Rogério Melo, pelas muitas preparações metalográficas e por todas as outras importantes contribuições para esse trabalho.

À Nicássia Vieira, Tarita Shiraishi e Adalberto Schiavetti pelo apoio e pela amizade. Sem vocês minha experiência aqui no IPT não teria a mesma graça. 


\section{SUMÁRIO}

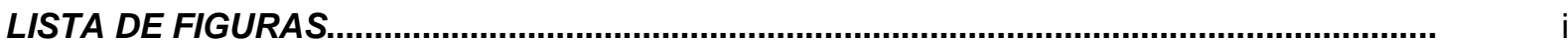

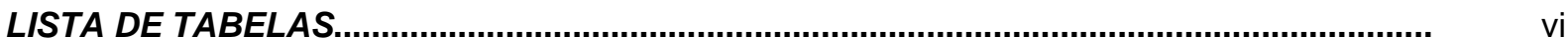

LISTA DE SÍMBOLOS...................................................................................................... v viii

RESUMO

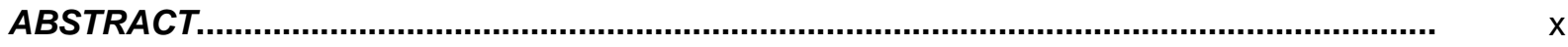

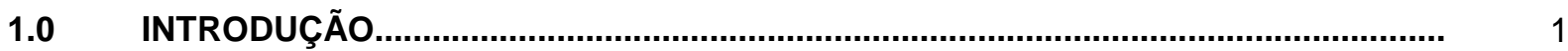

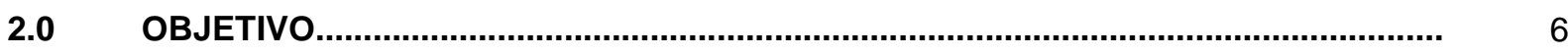

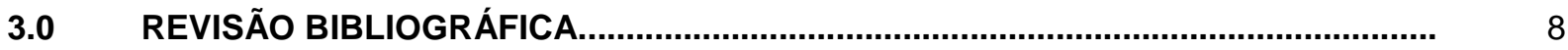

3.1 SILÍCIO GRAU METALÚRGICO E SILÍCIO GRAU SOLAR......................................

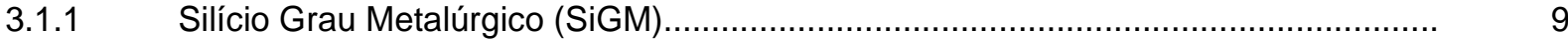

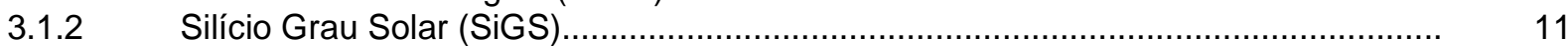

3.2 ROTAS DE OBTENÇÃO DO Si PARA PRODUÇÃO DE CÉLULAS SOLARES................ 13

3.2.1 Rota Tradicional para a Produção do Silício Grau Solar..............................................

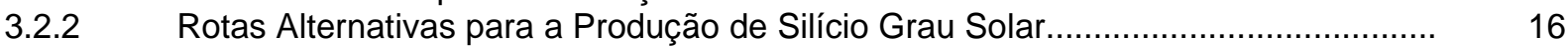

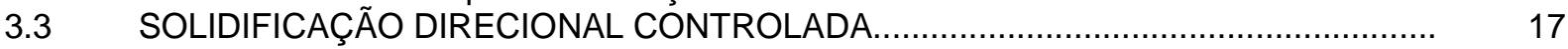

3.3.1 Transporte de Massa na Solidificação Direcional Controlada..................................... 18

3.3.1.1 Estágios da Solidificação Direcional Controlada...................................................... 18

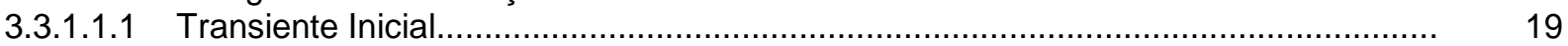

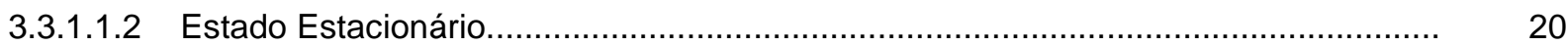

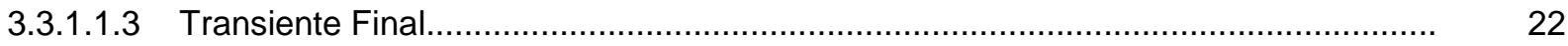

3.3.2 Análise Teórica do Efeito da Convecção no Transporte de Massa............................ 22

3.3.3 Análise Experimental do Transporte de Massa na Solidificação Direcional 27 Controlada

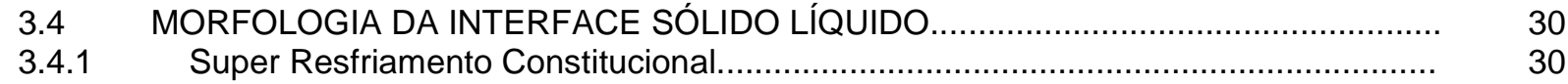

3.4.2 Instabilidade da Interface Devido ao Super Resfriamento Constitucional........................ 31

3.4.3 Ligas Multicomponentes..................................................................................

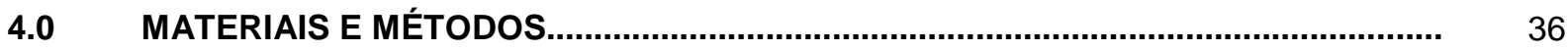

4.1 METODOLOGIA DO ENSAIO DE SOLIDIFICAÇÃO DIRECIONAL CONTROLADA.... 37

4.2 MONTAGEM DO MOLDE PARA SOLIDIFICAÇÃO DIRECIONAL ............................... 39

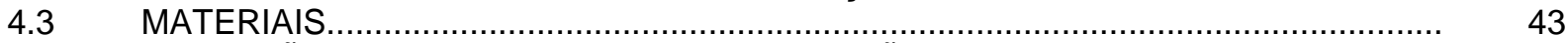

4.4 CONDIÇÕES DOS ENSAIOS DE SOLIDIFICAÇÃO DIRECIONAL .............................

4.5 DETERMINAÇÃO DA MORFOLOGIA DA INTERFACE SÓLIDO/LÍQUIDO ....................... 47

4.6 PREPARAÇÃO DAS AMOSTRAS PARA CARACTERIZAÇÃO.......................................

4.7 CARACTERIZAÇÃO MICRO E MACROESTRUTURAL........................................... 49

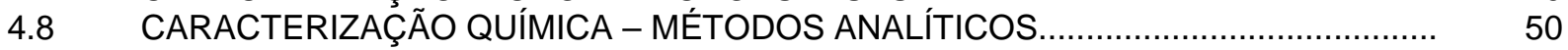

4.8.1 Caracterização Química por ICP-AES $\quad$............................................................... 50

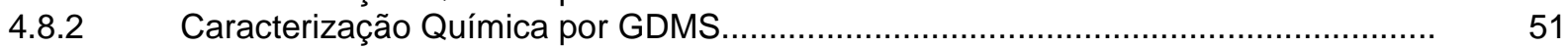

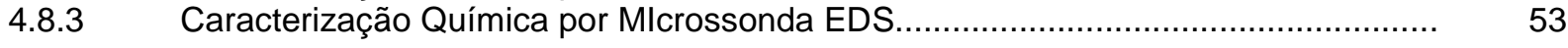

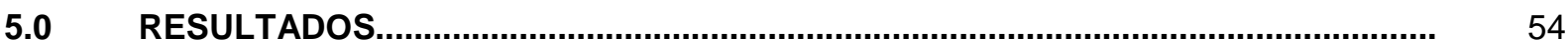

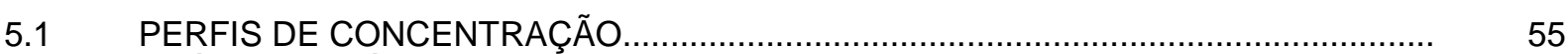

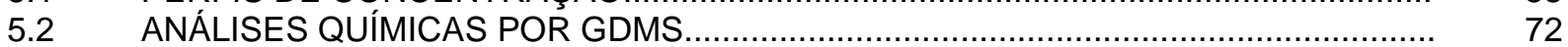

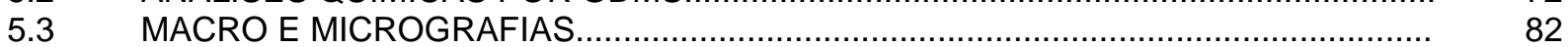

5.4 ANÁLISE POR MICROSSONDA EDS 93

5.5 VARIAÇÃO DE TEMPERATURA NO LÍQUIDO E TAXA DE RESFRIAMENTO............ 94

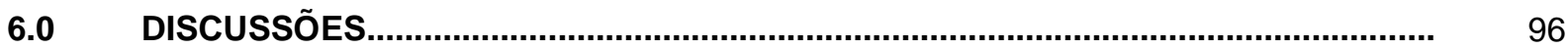

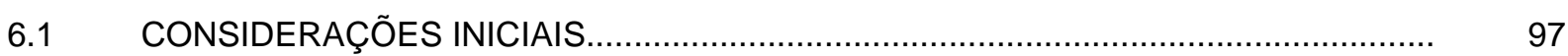

6.1.1 Considerações Preliminares Sobre os Perfis de Concentração de Elementos............ 97 


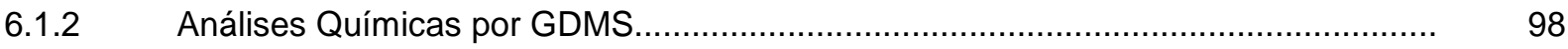

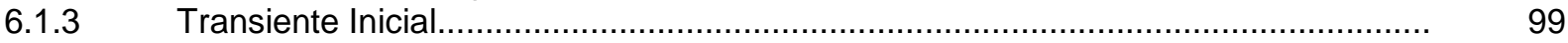

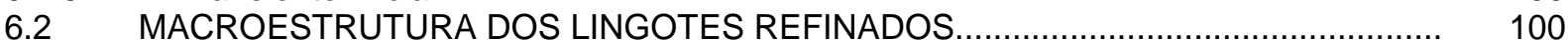

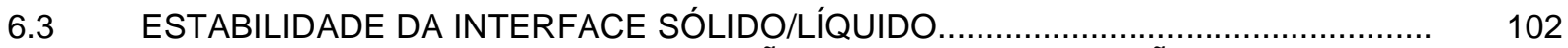

6.4 EFEITO DA VELOCIDADE DE EXTRAÇÃO E DA CONCENTRAÇÃO INICIAL............ 104

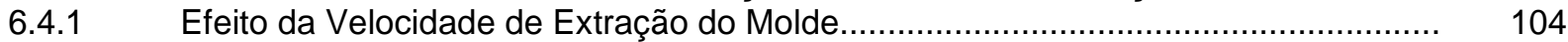

6.4.2 Efeito da Concentração Inicial da Matéria Prima................................................... 115

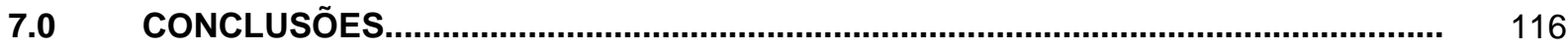

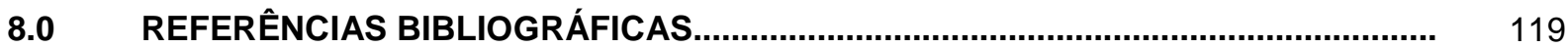

ANEXO Propriedades Físicas e Composições Químicas dos Cadinhos de Grafita e Tubos de 124 Quartzo 


\section{LISTA DE FIGURAS}

Figura 01 Evolução da produção mundial de energia fotovoltaica 12

Figura 02 Rotas de processamento para a produção de silício visando a indústria de 14 circuitos integrados ou a indústria fotovoltaica (silício grau solar)

Figura 03 Transiente inicial em um processo de solidificação

Figura 04 Estado estacionário em um processo de solidificação considerando transporte de soluto por difusão no líquido e sem difusão no sólido

Figura 05 Transiente final em um processo de solidificação

Figura 06 Representação da camada $\delta_{\mathrm{BPS}}$ considerando transporte de soluto por convecção no líquido e sem difusão no sólido

Figura 07 Super-resfriamento à frente de uma interface S/L

Figura 08 Super-resfriamento Constitucional na solidificação de uma liga

Figura 09 Representação de um diagrama de fases ternário e perfis de concentração de soluto no líquido na direção perpendicular á interface sólido-líquido

Figura 10 Forno vertical do tipo Bridgman utilizado nos ensaios de solidificação direcional ascendente

Figura 11 Molde para solidificação direcional dos ensaios preliminares

Figura 12 Montagem experimental utilizada na tentativa de obtenção do gradiente térmico

Figura 13 Microscopia Eletrônica de Varredura do SiGM com 3\%Ge solidificado sem controle

Figura 14 Esquema ilustrativo de um lingote cilíndrico de silício subdividido em várias amostras

Figura 15 Fatia de Si com a região a ser retirada para análise por GDMS demarcada

Figura 16 Representação da amostra levada ao GDMS

Figura 17 Lingote de silício solidificado direcionalmente

Figura 18a Perfis de concentração do Fe ao longo dos lingotes obtidos por solidificação direcional do silício em diferentes concentrações iniciais e diferentes velocidades de extração do molde

Figura 18b Perfis de concentração do Fe (escala logarítmica) ao longo dos lingotes obtidos por solidificação direcional do silício em diferentes concentrações iniciais e diferentes velocidades de extração do molde

Figura 19a Perfis de concentração do $\mathrm{Al}$ ao longo dos lingotes obtidos por solidificação direcional do silício em diferentes concentrações iniciais e diferentes velocidades de extração do molde

Figura 19b Perfis de concentração do Al (escala logarítmica) ao longo dos lingotes obtidos por solidificação direcional do silício em diferentes concentrações iniciais e diferentes velocidades de extração do molde 
Figura 20a Perfis de concentração do $\mathrm{Ca}$ ao longo dos lingotes obtidos por solidificação direcional do silício em diferentes concentrações iniciais e diferentes velocidades de extração do molde

Figura 20b Perfis de concentração do $\mathrm{Ca}$ (escala logarítmica) ao longo dos lingotes obtidos por solidificação direcional do silício em diferentes concentrações iniciais e diferentes velocidades de extração do molde

Figura 21a Perfis de concentração do $\mathrm{Cu}$ ao longo dos lingotes obtidos por solidificação direcional do silício em diferentes concentrações iniciais e diferentes velocidades de extração do molde

Figura 21b Perfis de concentração do $\mathrm{Cu}$ (escala logarítmica) ao longo dos lingotes obtidos por solidificação direcional do silício em diferentes concentrações iniciais e diferentes velocidades de extração do molde

Figura 22a Perfis de concentração do Ti ao longo dos lingotes obtidos por solidificação direcional do silício em diferentes concentrações iniciais e diferentes velocidades de extração do molde

Figura 22b Perfis de concentração do Ti (escala logarítmica) ao longo dos lingotes obtidos por solidificação direcional do silício em diferentes concentrações iniciais e diferentes velocidades de extração do molde

Figura 23a Perfis de concentração do $\mathrm{V}$ ao longo dos lingotes obtidos por solidificação direcional do silício em diferentes concentrações iniciais e diferentes velocidades de extração do molde

Figura 23b Perfis de concentração do V (escala logarítmica) ao longo dos lingotes obtidos por solidificação direcional do silício em diferentes concentrações iniciais e diferentes velocidades de extração do molde

Figura 24a Perfis de concentração do $\mathrm{Zn}$ ao longo dos lingotes obtidos por solidificação direcional do silício em diferentes concentrações iniciais e diferentes velocidades de extração do molde

Figura 24b Perfis de concentração do Zn (escala logarítmica) ao longo dos lingotes obtidos por solidificação direcional do silício em diferentes concentrações iniciais e diferentes velocidades de extração do molde

Figura 25a Perfis de concentração do $\mathrm{Zr}$ ao longo dos lingotes obtidos por solidificação direcional do silício em diferentes concentrações iniciais e diferentes velocidades de extração do molde

Figura 25b Perfis de concentração do Zr (escala logarítmica) ao longo dos lingotes obtidos por solidificação direcional do silício em diferentes concentrações iniciais e diferentes velocidades de extração do molde

Figura 26a Perfis de concentração do $\mathrm{Mn}$ ao longo dos lingotes obtidos por solidificação direcional do silício em diferentes concentrações iniciais e diferentes velocidades de extração do molde

Figura 26b Perfis de concentração do Mn (escala logarítmica) ao longo dos lingotes obtidos por solidificação direcional do silício em diferentes concentrações iniciais e diferentes velocidades de extração do molde

Figura 27a Perfis de concentração do $\mathrm{Cr}$ ao longo dos lingotes obtidos por solidificação direcional do silício em diferentes concentrações iniciais e diferentes velocidades de extração do molde 
Figura 27b Perfis de concentração do $\mathrm{Cr}$ (escala logarítmica) ao longo dos lingotes obtidos por solidificação direcional do silício em diferentes concentrações iniciais e diferentes velocidades de extração do molde

Figura 28a Perfis de concentração do $\mathrm{Ni}$ ao longo dos lingotes obtidos por solidificação direcional do silício em diferentes concentrações iniciais e diferentes velocidades de extração do molde

Figura 28b Perfis de concentração do Ni (escala logarítmica) ao longo dos lingotes obtidos por solidificação direcional do silício em diferentes concentrações iniciais e diferentes velocidades de extração do molde

Figura 29a Perfis de concentração do B ao longo dos lingotes obtidos por solidificação direcional do silício em diferentes concentrações iniciais e diferentes velocidades de extração do molde

Figura 29b Perfis de concentração do B (escala logarítmica) ao longo dos lingotes obtidos por solidificação direcional do silício em diferentes concentrações iniciais e diferentes velocidades de extração do molde

Figura 30a Perfis de concentração do $\mathrm{P}$ ao longo dos lingotes obtidos por solidificação direcional do silício em diferentes concentrações iniciais e diferentes velocidades de extração do molde

Figura 30b Perfis de concentração do $\mathrm{P}$ (escala logarítmica) ao longo dos lingotes obtidos por solidificação direcional do silício em diferentes concentrações iniciais e diferentes velocidades de extração do molde

Figura 31a Perfis de concentração TOTAL ao longo dos lingotes obtidos por solidificação direcional do silício em diferentes concentrações iniciais e diferentes velocidades de extração do molde. Ensaios Definitivos

Figura 31b Perfis de concentração total (escala logarítmica) ao longo dos lingotes obtidos por solidificação direcional do silício em diferentes concentrações iniciais e diferentes velocidades de extração do molde. Ensaios Definitivos

Figura 32a Perfis de concentração total ao longo dos lingotes obtidos por solidificação direcional do silício em diferentes concentrações iniciais e diferentes velocidades de extração do molde. Ensaios Preliminares

Figura 32b Perfis de concentração total (escala logarítmica) ao longo dos lingotes obtidos por solidificação direcional do silício em diferentes concentrações iniciais e diferentes velocidades de extração do molde. Ensaios Preliminares

Figura 33 Macrografia do lingote GM-05

Figura 34 Macrografia do lingote GM-10

Figura 35 Macrografia do lingote GM-20

Figura 36 Macrografia do lingote GM-110

Figura 37 Macrografia do lingote PR-05

Figura 38 Macrografia do lingote PR-10

Figura 39 Macrografia do lingote PR-20

Figura 40 Macrografia do lingote PR-110 
Figura $41 \quad$ Macrografia do lingote EP-08 85

Figura 42 Micrografia obtida em microscópio eletrônico de varredura (MEV) em 86

Figura 43 Micrografia obtida em microscópio eletrônico de varredura (MEV) em contraste de elétrons retroespalhados do topo do lingote GM-05 (SiGM; 5 $\square \mathrm{m} / \mathrm{s}$ )

Figura 44 Micrografia obtida em microscópio eletrônico de varredura (MEV) em contraste de elétrons retroespalhados do topo do lingote PR-05 (SiR; $5 \square \mathrm{m} / \mathrm{s}$ )

Figura 45 Microscopia óptica do lingote GM-05 (SiGM; $5 \mu \mathrm{m} / \mathrm{s}$ )

Figura 46 Microscopia óptica do lingote PR-05 (SiR; $5 \mu \mathrm{m} / \mathrm{s}$ )

Figura 47 Microscopia óptica do centro do lingote GM-110 (SiGM 110 $\mu \mathrm{m} / \mathrm{s}$ )

Figura 48 Microscopia óptica do centro do lingote GM-110 (SiGM 110 $\mathrm{mm} / \mathrm{s})$

Figura 49 Microscopia óptica do centro do lingote GM-110 (SiGM 110 $\mu \mathrm{m} / \mathrm{s}$ )

Figura 50 Microscopia óptica do centro do lingote PR-110 (SiR 110 $\mu \mathrm{m} / \mathrm{s})$

Figura 51 Microscopia óptica do centro do lingote GM-20 (SiGM 20 $\mu \mathrm{m} / \mathrm{s}$ )

Figura 52 Microscopia óptica do centro do lingote PR-20 (SiR 20 $\mu \mathrm{m} / \mathrm{s})$

Figura 53 Micrografia obtida em microscópio eletrônico de varredura (MEV) em contraste de elétrons retroespalhados do centro do lingote Si-3\%Ge (SiGM 5 $\mu \mathrm{m} / \mathrm{s})$ Seção Transversal

Figura 54 Micrografia obtida em microscópio eletrônico de varredura (MEV) em contraste de elétrons retroespalhados do centro do lingote Si-3\%Ge (SiGM 5 $\mu \mathrm{m} / \mathrm{s})$ Seção Transversal

Figura 55 Micrografia obtida em microscópio eletrônico de varredura (MEV) em contraste de elétrons retroespalhados do topo do lingote GM-05 indicando três pontos onde foram realizadas análises por microssonda (EDS)

Figura 56 Espectro obtido por microssonda (EDS) de um intermetálico no topo do lingote GM-05

Figura 57 Espectro obtido por microssonda (EDS) de um intermetálico no topo do lingote GM-05

Figura 58 Espectro obtido por microssonda (EDS) de um intermetálico no topo do lingote GM-05

Figura 59 Variação de temperatura no líquido antes da extração do molde

Figura 60 Microscopia óptica de uma região do centro do lingote PR-110

Figura 61 Microscopia óptica de uma região abaixo do topo do lingote PR-110

Figura 62 Concentração adimensional de Fe vs fração de sólido para os ensaios

Figura 63 Concentração adimensional de Al vs fração de sólido para os ensaios realizados com SiGM nas quatro diferentes velocidades de extração do molde 
Figura 64 Concentração adimensional de $\mathrm{Ti}$ vs fração de sólido para os ensaios realizados com SiGM nas quatro diferentes velocidades de extração do molde

Figura 65 Concentração adimensional de $\mathrm{Cu}$ vs fração de sólido para os ensaios realizados com SiGM nas quatro diferentes velocidades de extração do molde

Figura 66 Concentração adimensional de $\mathrm{Zr}$ vs fração de sólido para os ensaios realizados com SiGM nas quatro diferentes velocidades de extração do molde

Figura 67 Concentração adimensional de $V$ vs fração de sólido para os ensaios realizados com SiGM nas quatro diferentes velocidades de extração do molde

Figura 68 Concentração adimensional de $M n v s$ fração de sólido para os ensaios realizados com SiGM nas quatro diferentes velocidades de extração do molde

Figura 69 Concentração adimensional de $\mathrm{Ni}$ vs fração de sólido para os ensaios realizados com SiGM nas quatro diferentes velocidades de extração do molde

Figura 70 Concentração adimensional de $\mathrm{P}$ vs fração de sólido para os ensaios realizados com SiGM nas quatro diferentes velocidades de extração do molde

Figura 71 Concentração adimensional de Total vs fração de sólido para os ensaios realizados com SiGM nas quatro diferentes velocidades de extração do molde

Figura 72 Perfil de Scheil [1942] para o Fe

Figura 73 Regressão linear $(\log (\mathrm{Cs} / \mathrm{C} 0)$ vs $\log (1-\mathrm{fs}))$ para obtenção do coeficiente efetivo de partição do Fe no ensaio GM-110

Figura 74 Regressão linear $(\log (\mathrm{Cs} / \mathrm{C} 0)$ vs $\log (1-\mathrm{fs}))$ para obtenção do coeficiente efetivo de partição do Cu no ensaio GM-110

Figura 75 Regressão linear $(\log (\mathrm{Cs} / \mathrm{C} 0)$ vs $\log (1-\mathrm{fs}))$ para obtenção do coeficiente efetivo de partição do Al no ensaio GM-20 


\section{LISTA DE TABELAS}

Tabela $01 \quad$ Composição Média do SiGM

Tabela 02 Principais produtores de SiGM e suas respectivas produções em milhares de toneladas

Tabela 03

Preços do kg de SiGM nos últimos dez anos

Tabela 04 Concentrações de impurezas no SiGS

Taxa de Crescimento Anual de várias fontes de energia

Valores de k para diversas impurezas no Si

Composição química (ppm em peso) das matérias primas empregadas na solidificação direcional 
Tabela 29 Esquema demonstrativo da presença de intermetálicos

Tabela 30 Coeficientes de partição efetivos para $\mathrm{Fe}, \mathrm{Al}$, e Cu no silício

Tabela A1 Propriedades físicas dos cadinhos de grafita 124

Tabela A2 Composição química dos cadinhos de grafita 124

Tabela A3 Composição química dos tubos de quartzo 


\section{LISTA DE SÍMBOLOS}

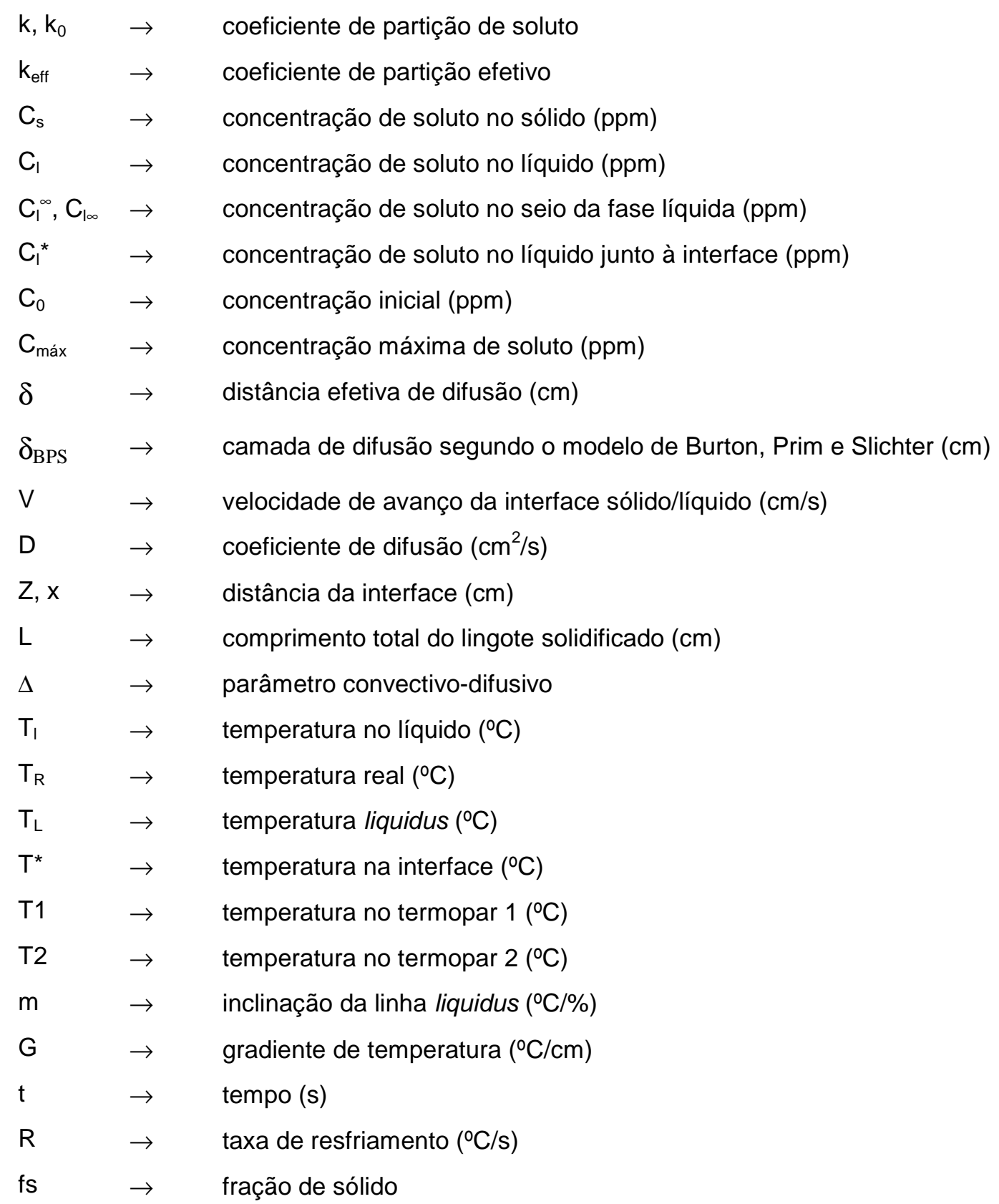




\section{RESUMO}

A demanda do silício de grau solar (SiGS) utilizado na indústria fotovoltaica cresce atualmente em uma média de $35 \%$ ao ano e a projeção para a próxima década é de constante crescimento. Entretanto, a disponibilidade de matéria-prima para a produção do SiGS não tem crescido na mesma taxa, resultando em uma elevação de seu custo. Logo, a obtenção de rotas alternativas menos onerosas para a produção do SiGS torna-se crucial, principalmente sendo o Brasil o $3^{\circ}$ maior produtor mundial de silício de grau metalúrgico. Tendo como objetivo a purificação do silício, o presente trabalho de pesquisa apresenta um estudo detalhado da solidificação direcional do silício, que é uma das etapas utilizadas em todas as rotas alternativas atualmente pesquisadas com o objetivo de purificação. Este estudo foi realizado em um forno do tipo Bridgman vertical, onde o silício líquido contido em um molde foi extraído da região quente do forno, resultando em uma solidificação direcional controlada e ascendente. Dois tipos de silício foram escolhidos como material de entrada para o processo de refino: o silício de grau metalúrgico e o silício de grau metalúrgico pré-refinado por lixiviação. Quatro velocidades de extração do molde entre 5 a $110 \mu \mathrm{m} / \mathrm{s}$ foram empregadas nos ensaios. A macrossegregação de impurezas nos lingotes obtidos foi medida através de análises químicas e a estrutura metalúrgica observada através de macro e micrografias. Os lingotes solidificados com menor velocidade de extração, onde se observa evidências de uma interface sólido-líquido plana, apresentam um grau de refino superior aos de maior velocidade, que mostram evidências de uma interface celular ou dendrítica. As análises químicas mostram que, após a solidificação direcional, os teores de $\mathrm{Fe}, \mathrm{Al}$, $\mathrm{Cr}$ e $\mathrm{Ti}$ medidos nas regiões da base e central dos lingotes atingem níveis especificados para o SiGS por alguns autores. 


\begin{abstract}
The demand for solar grade silicon (SiGS) in the photovoltaic industry has grown $35 \%$ per year and a constant growth rate is predicted for the next decade. The availability of feedstock to produce SiGS, however, has not grown at the same rate, resulting in increasing SiGS cost. Consequently, the development of less expensive alternative processing routes is of paramount importance to the photovoltaic industry in general, and particularly to Brazil, which is the $3^{\text {rd }}$ largest producer of metallurgical grade silicon. The objective of the present work is to study the directional solidification of silicon, which is a step adopted in virtually all alternative processing routes under development to refine silicon. The directional solidification of silicon was carried out in a vertical Bridgman furnace, where liquid silicon was poured into a quartz mold, which was extracted at constant velocity from the hot region of the furnace, resulting in ascending directional solidification. Two types of feedstock silicon were used, namely, a metallurgical grade silicon that was refined by leaching prior to directional solidification and metallurgical grade silicon as-received from the manufacturer. The quartz molds with liquid silicon were extracted at four different velocities in the range from 5 to $110 \mu \mathrm{m} / \mathrm{s}$. In the solidified silicon ingots, the macrosegregation of elements were measured using accurate analytical techniques, whereas the metallurgical structures were observed in macro and micrographs. The ingots solidified at lower extraction velocities, at which evidences of a planar solidliquid interface were observed, showed greater refining effect than those solidified at larger velocities, which showed evidences of a cellular or dendritic solid-liquid interface. The contents of $\mathrm{Fe}, \mathrm{Al}, \mathrm{Cr}$, and $\mathrm{Ti}$ measured at the base and center portions of the solidified ingots comply with the specifications of SiGS proposed by some authors.
\end{abstract}


CAPÍTULO 1

INTRODUÇÃO 


\subsection{INTRODUÇÃO}

O Silício (do latim, silicis = pedra) é o segundo elemento mais abundante na crosta terrestre perfazendo $26 \%$ do seu peso. Pode-se afirmar que praticamente todas as rochas, com exceção das rochas fosfáticas e carbonáceas, contêm silício sob a forma de sílica $\left(\mathrm{SiO}_{2}\right)$, ou sob a forma de um ou mais tipos de silicatos existentes. Consiste em um metalóide (elemento que possui propriedades químicas de um não-metal e propriedades físicas de um metal) que se encontra na natureza em rochas de silicatos $\left(\mathrm{SiO}_{3}{ }^{2-}\right)$ e como sílica $\left(\mathrm{SiO}_{2}\right)$ na areia. Foi identificado por Antoine Lavoisier em 1797 e isolado em 1824 por Jonz Jacob Berzelius (1779 1848) que obteve silício reduzindo termicamente a sílica com magnésio em pó, purificando-o em seguida mediante várias lavagens com ácido clorídrico até obter o elemento puro [Enciclopédia Tecnológica].

O silício é utilizado na produção de ligas metálicas, na indústria cerâmica (na forma de sílica e silicatos) e na obtenção de silicones. Também é um elemento de vital importância na construção civil. O dióxido de silício, areia e argila são importantes constituintes do concreto armado e azulejos, sendo empregados na produção do cimento Portland.

Outras importantes aplicações do silício metálico são a produção de transistores, circuitos integrados e a fabricação de células solares. Tais células são utilizadas na captação de energia solar visando sua conversão em energia elétrica. A energia solar vem ganhando cada vez mais espaço devido ao seu caráter não poluente e à sua abundância natural. Tudo isto associado a uma crescente demanda pelas chamadas "energias limpas" cria um quadro promissor para a pesquisa e utilização deste material.

No início da década de setenta, a crise do petróleo associada à preocupação em buscar novas fontes de energia em substituição aos combustíveis fósseis fez com que pesquisas na área de energias limpas fossem realizadas. Com isto o interesse pela energia solar, e conseqüentemente pelo refino de silício, se tornou cada vez maior [MADEIRA et al. 2003]. 
O silício denominado de grau solar é utilizado em aplicações que empregam a conversão de energia solar em energia fotovoltaica. Por outro lado, o silício chamado de grau eletrônico é utilizado na produção de semicondutores e possui um nível de impurezas menor do que o de grau solar. Enquanto o silício de grau eletrônico é produzido por processos químicos de alto custo, o silício de grau solar era obtido, até pouco tempo, dos descartes da indústria de obtenção do silício de grau eletrônico. No entanto, como a demanda do silício de grau solar cresceu na faixa de 25 a 40\% ao ano nas últimas duas décadas [CISZEK,2001], em decorrência dos programas de substituição de energias baseadas em combustíveis fósseis por energias alternativas, a disponibilidade de sucata de silício de grau eletrônico tornouse insuficiente para a produção de células solares. As alternativas para suprir esta demanda são duas. A primeira visa tentar desenvolver processos derivados do próprio processo de obtenção do SiGE, ou seja, processos químicos adaptados para produzirem um silício de qualidade inferior ao SiGE mas que atenda a exigência de obtenção de células solares. Obviamente, estes processos devem ter custo inferior ao praticado na produção do SiGE. A segunda alternativa é tentar adaptar etapas metalúrgicas de purificação (piro e hidrometalúrgicas) ao silício grau metalúrgico, de forma a tentar obter um silício compatível com as exigências do silício de grau solar.

O Brasil é o $3^{\circ}$ maior produtor mundial do silício grau metalúrgico [United States Geological Survey, 2004], que possui um nível de pureza de cerca de $99 \% \pm$ 0,5. Este silício tem menor valor agregado quando comparado aos silícios de grau solar ou eletrônico. O silício de grau metalúrgico é comercializado a aproximadamente US\$1,5/kg enquanto o Si de grau eletrônico atinge valores de aproximadamente US $\$ 50$ a 60/kg no mercado [MOEHLECKE e ZANESCO, 2007]. Conseqüentemente, há uma clara motivação econômica para a modernização da tecnologia brasileira no sentido de produzir um silício de maior pureza através de processos alternativos de refino do silício nacional. Este tipo de desenvolvimento representaria uma importante contribuição para permitir a exportação de um produto de valor agregado muito superior ao que se exporta no momento.

O silício utilizado tanto na indústria microeletrônica como na fabricação de células solares necessita de um grau de pureza compatível com uma concentração máxima de elementos da ordem de $10^{-5} \%$ em peso no caso das células fotovoltaicas e $10^{-8} \mathrm{ppm}$ em peso no caso da indústria microeletrônica [MORITA, 2003]. O 
processo de obtenção de SiGE e, conseqüentemente de sua sucata empregada na produção de células solares, é um complexo processo químico. Mesmo a adaptação deste processo para obtenção de um silício de menor custo e compatível com a mínima pureza para obtenção de células solares é complexa, já que exige o domínio da tecnologia de obtenção de SiGE. Por outro lado, a adaptação de uma rota de purificação piro e/ou hidrometalúrgica ao silício grau metalúrgico seria mais fácil, já que as operações unitárias que seriam empregadas certamente estão mais próximas da realidade da indústria metalúrgica de produção de silício grau metalúrgico. É justamente neste contexto que se encaixa o estudo apresentado neste trabalho, que visa a obtenção de informações que auxiliem no desenvolvimento destas rotas alternativas, onde uma delas é a solidificação direcional controlada.

Durante as últimas décadas, muitos trabalhos foram realizados tendo como tema a solidificação. Vários trabalhos podem ser citados, cada qual com sua contribuição para o meio acadêmico. Na década de sessenta, Clark et al [1960], Dean et al [1961], Hellawell [1965], dentre vários outros, estudaram a segregação de soluto em processos de solidificação direcional controlada de ligas metálicas. Nestes trabalhos, a teoria do super-resfriamento constitucional, que visa prever a estabilidade da interface sólido/líquido, foi bastante abordada. A estes trabalhos acrescentaram-se os realizados por Flemings et al. na década de setenta, que tentaram expandir o critério do super-resfriamento constitucional para o crescimento de cristais em ligas ternárias e multifásicas [FLEMINGS, 1974].

Bolzan et al. [1984] foram os pioneiros em estudar a solidificação direcional de silício no Brasil. Eles solidificaram direcionalmente em forno tipo Bridgman duas matérias primas: um silício grau metalúrgico e um silício pré-refinado por lixiviação. Alguns perfis de concentração de impurezas foram gerados, mas o efeito do refino não pôde ser completamente visualizado porque grande parte dos teores ficou abaixo dos limites de detecção das técnicas analíticas empregadas à época. Também neste trabalho não foram abordadas questões relativas ao transporte de massa na interface sólido/líquido.

Radojevic et al. [2002] investigaram a influência da velocidade da interface e da concentração inicial de soluto em ligas de Al-Cu solidificadas em um forno Bridgman. O coeficiente de partição efetivo do cobre foi calculado para as várias velocidades utilizadas e a relação entre $\mathrm{K}_{\text {eff }}$ do cobre e a velocidade de avanço da interface foi obtida. 
Revel et al [1987] estudaram o refino de silício por solidificação direcional em cadinhos de carbono utilizando uma técnica de solidificação direcional denominada HEM (Heat Exchange Method). Duas matérias primas foram utilizadas: silício de grau eletrônico e um silício de grau metalúrgico pré-refinado. Alguns perfis de concentração foram obtidos ao longo dos lingotes refinados e com base nos dados de concentração obtidos. foi realizado o cálculo do coeficiente de partição efetivo do boro e do alumínio.

Yuge et al. [1994] purificaram silício através de várias etapas de refino envolvendo solidificação direcional controlada, fusão em forno a vácuo, aplicação de plasma de argônio e injeção de argônio no líquido e uma nova etapa de solidificação direcional. Um estudo da morfologia da interface e uma análise mais profunda sobre o transporte de massa não foram realizados.

Não foram encontrados na literatura trabalhos que apresentassem um estudo mais fundamental abordando a transferência de massa durante a purificação do silício por solidificação direcional. Esta abordagem fundamental deveria envolver o estudo dos perfis de concentração de elementos, a investigação dos modelos de transferência de massa que melhor se ajustam à solidificação do silício, a obtenção de coeficientes de partição efetivo, o efeito da velocidade de avanço da interface sólido-líquido, entre outros.

Este trabalho é uma tentativa de preencher algumas dessas lacunas. 
CAPÍTULO 2

OBJETIVO 


\subsection{OBJETIVO}

Este trabalho tem como objetivo estudar aspectos macro-microestruturais e de transferência de massa no refino do sílicio através do processo de solidificação direcional conduzido em um forno do tipo Bridgman. Especificamente, pretende-se mostrar o efeito da composição química inicial do silício e da velocidade de extração do molde no processo de refino. 
CAPÍTULO 3

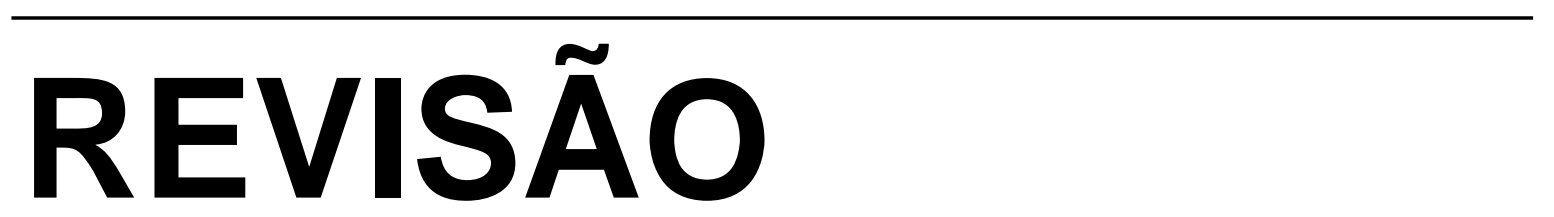
BIBLIOGRÁFICA 


\subsection{REVISÃO DE LITERATURA}

\subsection{Silício Grau Metalúrgico e Silício Grau Solar}

\subsubsection{Silício Grau Metalúrgico (SiGM)}

Silício grau metalúrgico (SiGM) é um termo utilizado para fazer referência ao silício empregado na indústria metalúrgica [TRUNZO, 1996]. É obtido a partir da redução carbotérmica da sílica em fornos de arco elétrico, onde o óxido de silício $\left(\mathrm{SiO}_{2}\right)$ é reduzido com o uso de eletrodos de carbono a temperaturas superiores a $1900^{\circ} \mathrm{C}$ segundo a reação [Schei, 1998]:

$$
\mathrm{SiO}_{2}+2 \mathrm{C} \rightarrow \mathrm{Si}+\mathrm{CO}
$$

No final do processo, o silício líquido acumula-se no fundo do forno, de onde é extraído e posteriormente resfriado. O silício oriundo deste processo é denominado de Silício Grau Metalúrgico (SiGM) e apresenta um teor de impurezas de aproximadamente 1\% $\pm 0,5$ em massa. As impurezas contidas no SiGM devem-se ao processo de redução, ou seja, o grau de pureza está associado à qualidade dos materiais utilizados na redução, a saber, o material de partida (quartzo) e a fonte geradora de carbono (normalmente carvão vegetal). Este silício ainda não é apropriado para aplicação em dispositivos semicondutores e células solares. Para tanto, é necessário que o SiGM seja submetido a determinadas técnicas de purificação.

A composição do SiGM, como já dito anteriormente, varia de acordo com a qualidade e grau de pureza do material de partida utilizado. Alguns autores reportam valores diferentes de composição inicial do SiGM. Porém, embora diferentes, esses valores se encontram dentro de uma mesma ordem de grandeza. A Tabela 1 mostra valores típicos de composição inicial do SiGM. 


\begin{tabular}{|l|l|l|}
\hline \multirow{2}{*}{ Impureza } & \multicolumn{2}{|l|}{ Composição (ppm massa) } \\
\cline { 2 - 3 } & {$[$ BATHEY, 1982] } & {$[$ [PIZZINI, 1979] } \\
\hline $\mathrm{Al}$ & $1000-4000$ & $>5000$ \\
\hline $\mathrm{C}$ & $1000-3000$ & 500 \\
\hline $\mathrm{B}$ & $40-60$ & $10-100$ \\
\hline $\mathrm{Fe}$ & $1500-6000$ & $1000-3000$ \\
\hline $\mathrm{Ti}$ & $120-275$ & $30-400$ \\
\hline $\mathrm{P}$ & $20-45$ & $50-100$ \\
\hline $\mathrm{Cr}$ & $40-220$ & $30-300$ \\
\hline $\mathrm{Cu}$ & $15-40$ & $10-100$ \\
\hline $\mathrm{Mg}$ & - & $10-100$ \\
\hline $\mathrm{Mn}$ & $10-80$ & $30-300$ \\
\hline $\mathrm{Ni}$ & $10-95$ & $10-100$ \\
\hline $\mathrm{V}$ & $15-250$ & $100-1000$ \\
\hline $\mathrm{Ca}$ & $250-620$ & $\mathrm{NA}$ \\
\hline $\mathrm{Zr}$ & $15-25$ & $\mathrm{NA}$ \\
\hline
\end{tabular}

Dados do United States Geological Survey referentes ao ano de 2004, colocam o Brasil como terceiro maior produtor de SiGM do mundo com uma produção de 225.000 toneladas, valor inferior apenas às produções da China (520.000 toneladas) e Estados Unidos (276.000 toneladas). Os outros grandes produtores mundiais de SIGM são, em ordem decrescente: Noruega, Rússia, França e África do Sul [U. S. GEOLOGICAL SURVEY, 2004]. A Tabela 2 mostra a evolução da produção mundial de SiGM nos principais países produtores nos últimos anos.

Tabela 2 - Principais produtores de SiGM e suas respectivas produções em milhares de toneladas.

\begin{tabular}{|c|c|c|c|c|c|}
\hline País & 2000 & 2001 & 2002 & 2003 & 2004 \\
\hline China $^{a *}$ & $x$ & $x$ & 340.000 & 300.000 & 520.000 \\
\hline$E^{\prime} \cup A^{a}$ & 367.000 & 282.000 & 285.000 & 315.000 & 276.000 \\
\hline Brasil $^{b}$ & 166.344 & 112.123 & 133.390 & 180.937 & 219.813 \\
\hline Noruega $^{c}$ & 100.000 & 100.000 & 105.000 & 100.000 & 105.000 \\
\hline França $^{c}$ & 75.000 & 75.000 & 75.000 & 75.000 & 75.000 \\
\hline Rússia $^{c}$ & 40.000 & 40.000 & 45.000 & 45.000 & 45.000 \\
\hline Áf. Sul ${ }^{C}$ & 40.600 & 39.400 & 42.500 & 48.900 & 49.000 \\
\hline Austrália $^{\mathrm{C}}$ & 30.000 & 30.000 & 30.000 & 30.000 & 30.000 \\
\hline
\end{tabular}


Nos últimos dez anos, o preço do SiGM tem oscilado na faixa entre US $\$ 1,00$ e US\$2,00 por kg. A Tabela 3 abaixo mostra a evolução dos preços do silício grau metalúrgico no mercado internacional nos últimos dez anos.

Tabela 3 - Preços do kg de SiGM nos últimos dez anos.

\begin{tabular}{|c|c|}
\hline Ano & Preço (US\$) \\
\hline 1996 & 1,97 \\
\hline 1997 & 1,79 \\
\hline 1998 & 1,55 \\
\hline 1999 & 1,28 \\
\hline 2000 & 1,21 \\
\hline 2001 & 1,11 \\
\hline 2002 & 1,17 \\
\hline 2003 & 1,35 \\
\hline 2004 & 1,80 \\
\hline 2005 & 1,69 \\
\hline
\end{tabular}

Fonte: [U. S. GEOLOGICAL SURVEY]

\subsubsection{Silício Grau Solar (SiGS)}

O termo silício grau solar (SiGS) não se refere a um material com nível de pureza específico, ou seja, não existe um padrão rígido em termos de concentração de impurezas como acontece com o silício grau eletrônico (SiGE). A pureza do SiGS é definida em termos da eficiência de conversão da energia solar em energia elétrica e não em termos de concentração de impurezas. Segundo Pizzini [1982], o silício pode ser considerado grau solar quando o mesmo possibilita a obtenção de células solares com eficiência de conversão maior que 10\%. A classificação do SiGS em termos de limites de concentração de impureza varia de autor para autor. Em decorrência disto, encontram-se na literatura padrões conflitantes de classificação. Yuge [1994] e Jain [1981] classificam como SiGS o material com no máximo 10 ppm (em massa) de impurezas. Para Ikeda [1992], este valor não pode exceder 0,1 ppm em massa. Para Bathey [1982], um material com nível de impureza na faixa entre 10 e 50 ppm em massa pode ser considerado SiGS.

A Tabela 4 mostra os teores aceitáveis para alguns elementos no SiGS. 
Tabela 4 - Concentrações de impurezas no SiGS [SARTI e EINHAUS, 2002].

\begin{tabular}{|c|c|}
\hline Elemento & Concentração $(\mathbf{p p m})$ \\
\hline $\mathrm{B}$ & $<1$ \\
\hline $\mathrm{P}$ & $<5$ \\
\hline $\mathrm{O}$ & $<10$ \\
\hline $\mathrm{C}$ & $<10$ \\
\hline $\mathrm{Fe}$ & $<10$ \\
\hline $\mathrm{Al}$ & $<2$ \\
\hline $\mathrm{Ca}$ & $<2$ \\
\hline $\mathrm{Ti}$ & $<1$ \\
\hline $\mathrm{Cr}$ & $<1$ \\
\hline
\end{tabular}

Os valores acima referem-se aos teores de impurezas antes da solidificação direcional final do processo de obtenção do SiGS.

Outros fatores também estão associados com a eficiência de conversão além da concentração de impurezas; são eles o processo de fabricação da célula e a presença de defeitos estruturais no material [BRAGA, 1997].

O SiGS é aplicado na conversão de energia solar em energia elétrica. Este meio de captação de energia cresce cada vez mais em decorrência da necessidade de se obter fontes de energia livres de ação poluente. Sabe-se que o petróleo, embora acessível em termos de oferta, consiste em uma matriz energética altamente poluidora. Por esse motivo, o consumo de energia oriunda de painéis fotovoltaicos cresceu assustadoramente nas últimas três décadas. A Figura 1 mostra a evolução da produção mundial de energia fotovoltaica desde meados da década de 70 até o ano de 2003.

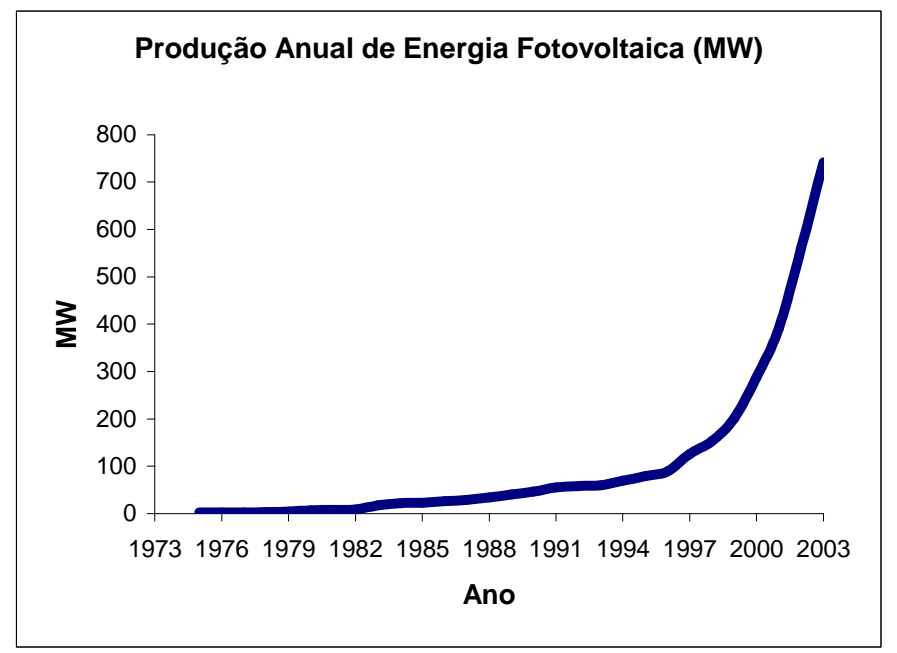

Figura 1 - Evolução da produção mundial de energia fotovoltaica Fonte: http://www.earth-policy.org/ 
Percebe-se um grande salto na produção mundial de energia fotovoltaica. No ano de 1975, apenas 2 MW foram produzidos. Em contrapartida, em 2003 este número saltou para $742 \mathrm{MW}$. Isto corresponde a um crescimento de $32 \%$ em relação aos 560 MW produzidos no ano anterior. A produção acumulada de 1975 a 2003 alcança um valor de $3.145 \mathrm{MW}$, o suficiente para fornecer energia elétrica para mais de um milhão de residências. A indústria de painéis fotovoltaicos espera um aumento de 40 a 50\% por ano nos próximos anos. Já a indústria de células solares cresceu uma média de $27 \%$ ao ano nos últimos 5 anos. Este extraordinário crescimento se deve aos incentivos governamentais e significativos avanços tecnológicos no setor. A Tabela 5 mostra uma comparação entre as taxas de crescimento anual de várias fontes de energia nos últimos 10 anos [Earth Policy Institute, 2006].

Tabela 5 - Taxa de Crescimento Anual de várias fontes de energia.

Fonte: http://www.earth-policy.org/

\begin{tabular}{|c|c|}
\hline Fonte de Energia & $\begin{array}{l}\text { Taxa de Crescimento } \\
\text { Anual (\%) }\end{array}$ \\
\hline Eólica & 28,6 \\
\hline Solar Fotovoltaica & 26,2 \\
\hline Geotérmica & 3,1 \\
\hline Hidroelétrica & 1,2 \\
\hline Petróleo & 1,7 \\
\hline Gás Natural & 2,5 \\
\hline Energia Nuclear & 1,9 \\
\hline Carvão & 2,3 \\
\hline
\end{tabular}

\subsection{Rotas de Obtenção do Silício para Produção de Células Solares}

A Figura 2 apresenta as rotas de processamento para a produção da maior parte dos circuitos integrados e células solares. A etapa inicial na produção dos dois tipos de silício (SiGE e SiGS) é a obtenção do silício de grau metalúrgico (SiGM), contendo um nível total de impurezas de aproximadamente $1,5 \times 10^{4}$ ppmw (98,5\%Si) [MORITA e MIKI, 2003; WOLDITSCH e KOCH, 2002]. Especificamente para a produção do SiGS, existem duas rotas: a rota tradicional (rota 1) e a rota alternativa (rota 2). 


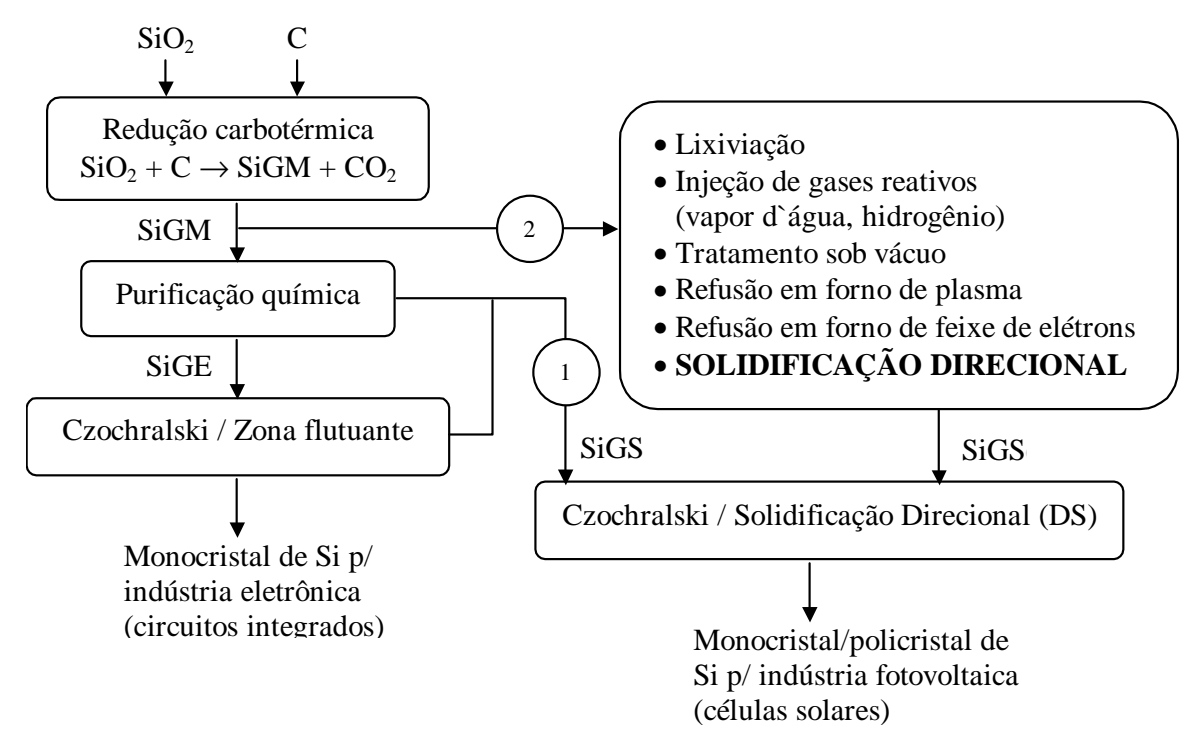

Figura 2 - Rotas de processamento para a produção de silício visando a indústria de circuitos integrados ou a indústria fotovoltaica (silício grau solar). Na produção de silício de grau solar, a rota 1 é tradicionalmente utilizada, enquanto a rota 2 representa o caminho alternativo.

\subsubsection{Rota Tradicional para Produção do Silício Grau Solar}

Na rota tradicional para a produção do SiGS, o SiGM é purificado através de processos químicos dos quais um deles se destaca por ser o principal: o método Siemens [Schei,1998]. Neste processo, o silício grau metalúrgico é submetido à reação com $\mathrm{HCl}$ gasoso à $300 \stackrel{\circ}{ } \mathrm{C}$ gerando triclorosilano e hidrogênio:

$$
\mathrm{Si}+3 \mathrm{HCl}_{(\mathrm{g})} \rightarrow \mathrm{HSiCl}_{3(\mathrm{~g})}+\mathrm{H}_{2}(\mathrm{~g})
$$

O triclorosilano formado é purificado por destilação e submetido a seguinte reação com $\mathrm{H}_{2}$ à $1100^{\circ} \mathrm{C}$ :

$$
4 \mathrm{HSiCl}_{3(\mathrm{~g})}+2 \mathrm{H}_{2}(\mathrm{~g}) \rightarrow 3 \mathrm{Si}+\mathrm{SiCl}_{4}+8 \mathrm{HCl}
$$

Esta reação ocorre na presença de barras de silício ultra-puro previamente inseridas dentro de um reator de CVD (Chemical Vapor Deposition) e submetidas a uma corrente elétrica durante todo o processo. O silício metálico obtido através da reação 3 é lentamente depositado nessas barras e apresenta uma fração de impurezas da ordem de $10^{-9} \mathrm{ppm}$ [MORITA,2003], sendo denominado silício grau eletrônico (SiGE) por ser apropriado para a fabricação de compostos eletrônicos. Ao final desta etapa tem-se o SiGE, que será o material de entrada no processo de 
solidificação direcional para produção de Si monocristalino com a menor quantidade de defeitos cristalinos possíveis visando a indústria de componentes eletrônicos.

Há basicamente dois processos de solidificação direcional para a obtenção do lingote de silício monocristalino e isento de defeitos cristalinos: o crescimento Czochralski (CZ) e o crescimento em zona flutuante (FZ - "Floating Zone"), que é uma evolução do processo de refino zonal [ZULEHNER, 2000]. Estes processos têm como principal objetivo a obtenção de lingotes de Si monocristalino livres de defeitos e homogêneos. Logo, não há considerações detalhadas em relação ao possível refino de composição causado pela segregação de impurezas, pois o material de entrada (SiGE) já apresenta um nível de pureza suficiente. Além disso, quando o transporte de soluto é analisado no processo, o objetivo é sempre obter um lingote homogêneo, sem segregação, ao contrário do que se deseja no processo de refino.

Os lingotes obtidos pela solidificação direcional estão prontos para a produção dos "wafers" para a fabricação de circuitos integrados. O SiGE tem um custo relativamente elevado devido principalmente aos custos do processo de purificação química. Durante as etapas de purificação química e de solidificação direcional para a produção do SiGE são produzidos vários rejeitos ou produtos derivados de silício com um nível de impurezas maior do que aquele permitido na produção do SiGE [WOLDITSCH e $\mathrm{KOCH}$, 2002], porém tolerado na produção do SiGS. Atualmente estes rejeitos são a maior fonte de material ("feedstock") para a produção do SiGS. Para obtenção das células solares, o SiGS é processado através da solidificação direcional, que pode ser de dois tipos: o Czochralski (CZ), onde a velocidade da interface sólido/líquido e gradiente de temperatura são separadamente controlados, ou um processo de solidificação direcional simples, onde o metal solidifica em contato com uma base extratora de calor, possuindo menor custo [National Center for Photovoltaics, 2006]. No primeiro processo, é possível se obter um monocristal, porém no segundo obtém-se um lingote policristalino. Estes lingotes estão prontos para serem utilizados na produção dos "wafers" para as células solares. Novamente, deve-se salientar que nestes dois tipos de processos de solidificação direcional não se tem o objetivo de eliminação de impurezas. 


\subsubsection{Rotas Alternativas para Produção do Silício Grau Solar}

As células solares produzidas pela rota tradicional são obtidas a partir do rejeito do processo de obtenção do SiGE pela redução do tricloro-silano, discutida no item anterior. Porém, atualmente este rejeito não supre completamente a demanda de material para a produção de células solares. Além disso, a produção de silício através da rota tradicional especificamente para ser utilizado na obtenção de células solares não é economicamente viável. Conseqüentemente, rotas alternativas para a produção do SiGS a partir do SiGM vêm sendo estudadas.

Diversas rotas foram propostas para a produção de SiGS, porém ainda não existe um consenso sobre a mais adequada [WOLDITSCH e $\mathrm{KOCH}, 2002$ ]. Com exceção da rota que propõe a produção de SiGS diretamente a partir da redução carbotérmica utilizando carbono e sílica de alta pureza [WOLDITSCH e $\mathrm{KOCH}$, 2002], praticamente todas as rotas alternativas baseiam-se na obtenção de SiGS a partir da purificação do SiGM. Estas rotas empregam uma combinação de diversas etapas de purificação [WOLDITSCH e KOCH, 2002; CISZEK et al., 2001; YUGE et al., 2001; SCHEI, 1986; PIRES et al., 2000]: lixiviação; refusão em forno de feixe de elétrons; tratamentos em forno de aquecimento a plasma; tratamentos sob vácuo; tratamentos por injeção de gases reativos e solidificação direcional (Figura 2).

Cada etapa tem o objetivo de eliminar um certo tipo ou grupo de impurezas. A solidificação direcional é efetiva para a eliminação de um grande número de impurezas, porém é incapaz de reduzir significativamente os teores de P e B. A refusão em forno de feixe de elétrons, por outro lado, permite a eliminação de $P$, enquanto o tratamento em forno a plasma permite a eliminação de B [YUGE et al., 2001]. O tratamento sob vácuo pode eliminar impurezas como $P$ e $O$ através da volatilização do próprio elemento ou de algum composto deste elemento [KHATTAK et al., 2002]. Geralmente uma combinação de diversas destas etapas é utilizada, porém ainda não há um consenso sobre qual a seqüência ou mesmo quais as etapas que devem ser utilizadas para se obter um nível de impurezas compatível com o SiGS. 


\subsection{Solidificação Direcional Controlada}

O processo de solidificação direcional é utilizado como uma etapa de purificação das rotas alternativas, como mostra a Figura 2. De forma geral, durante a solidificação direcional, um aumento do gradiente de temperatura está associado a um aumento de extração de calor e, portanto, a um aumento da velocidade de solidificação. Entretanto, na solidificação direcional controlada, conduzida por exemplo em um forno do tipo Bridgman, o gradiente de temperatura e a velocidade de solidificação são alterados independentemente dentro de uma determinada faixa.

A capacidade de purificação do processo de solidificação pode ser entendida de forma geral examinando-se o coeficiente de partição de soluto das impurezas presentes. Este coeficiente é definido para uma dada impureza como [KURZ e FISHER, 1989]:

$$
k=\frac{C_{s}}{C_{l}}
$$

onde $\mathrm{C}_{\mathrm{s}}$ e $\mathrm{C}_{\mid}$representam a concentração de um dado elemento ou impureza no sólido e no líquido, respectivamente, em equilíbrio a uma dada temperatura e composição. Os valores de $\mathrm{k}$ dependem da impureza, da temperatura e da composição da liga, mas estão na faixa de $10^{-2}$ a $10^{-6}$ para grande parte das impurezas contidas no silício, como mostra a Tabela 6. Logo, durante o processo de solidificação as impurezas são naturalmente segregadas no líquido residual. Especificamente no caso da solidificação direcional controlada, as impurezas podem ser segregadas para um extremo do lingote, que seria descartado, deixando uma porção com um nível de impurezas muito menor do que o material inicial, ou seja, refinando o material inicial.

Como pode ser observado na Tabela 6, elementos como $\mathrm{P}$ e B possuem coeficientes de partição muito maiores do que a maioria dos outros elementos. Conseqüentemente, durante a solidificação direcional existe uma menor tendência à segregação destas impurezas, que devem ser eliminadas por outros processos. 
Tabela 6- Valores de k para diversas impurezas no Si (Schei, 1986; Müller, 1988)

\begin{tabular}{|c|c|c|c|c|c|}
\hline Elemento & $\mathrm{k}$ & Elemento & $\mathrm{k}$ & Elemento & $\mathrm{k}$ \\
\hline $\mathrm{Al}$ & $210^{-3}$ & $\mathrm{Cu}$ & $410^{-4}$ & $\mathrm{~S}$ & $10^{-5}$ \\
\hline As & 0.3 & $\mathrm{Fe}$ & $810^{-6}$ & Sn & $210^{-2}$ \\
\hline $\mathrm{Au}$ & $210^{-5}$ & $\mathrm{Ge}$ & 0.33 & $\mathrm{Ta}$ & $10^{-7}$ \\
\hline B & 0.8 & $\mathrm{Mg}$ & $210^{-3}$ & $\mathrm{Ti}$ & $10^{-5}$ \\
\hline C & $810^{-2}$ & $\mathrm{Mn}$ & $10^{-5}$ & V & $10^{-5}$ \\
\hline $\mathrm{Ca}$ & $1,610^{-3}$ & $\mathrm{Na}$ & $210^{-3}$ & $\mathrm{Zn}$ & $10^{-5}$ \\
\hline Co & $810^{-6}$ & $\mathrm{Ni}$ & $10^{-4}$ & $\mathrm{Zr}$ & $1,510^{-8}$ \\
\hline $\mathrm{Cr}$ & $10^{-5}$ & $\mathrm{P}$ & 0.35 & & \\
\hline
\end{tabular}

Alguns pesquisadores reportaram resultados positivos da utilização da solidificação direcional como uma etapa de purificação para a produção do SiGS [YUGE et al., 2001; YUGE et al., 1997; BOLZAN et al. 1984]. Entretanto, Morita e Miki [2003] mencionaram que o custo da etapa de solidificação direcional em uma possível rota de produção do SiGS é elevado e, desta forma, o número de etapas de solidificação necessárias para reduzir o teor de impurezas deve ser minimizado. Atualmente, existe um processo de crescimento de $\mathrm{Si}$ baseado na solidificação direcional chamado de HEM ("Heat Exchanger Method") [KHATTAK et al., 2002]. Mas este método ainda não é utilizado para refino de silício, apenas para o crescimento direcional dos grãos.

\subsubsection{Transporte de Massa na Solidificação Direcional Controlada}

\subsubsection{Estágios da Solidificação Direcional Controlada}

Em um processo geral de rejeição de soluto devido à movimentação da interface sólido-líquido, com ou sem convecção no líquido em contato, geralmente ocorre transporte de soluto da região da interface para o interior do sólido e para o interior do líquido. O fluxo de massa que origina este transporte está associado a um gradiente de concentração (do elemento transportado) junto à interface, na fase em que o transporte está ocorrendo. Este gradiente pode ser utilizado para se calcular uma distância efetiva de difusão no líquido, junto à interface, $\delta$, como indicado a seguir 


$$
\delta=\frac{C_{l}^{*}-C_{l}^{\infty}}{-\left.\frac{\partial C_{l}}{\partial z}\right|_{z=z_{i}}}
$$

onde $\mathrm{C}_{\mid}^{\infty}$ representa a concentração de soluto no líquido suficientemente distante da interface, $\mathrm{C}_{1}{ }^{*}$ é a concentração no líquido junto à interface

Nestes processos, considerando-se interface plana e ausência de convecção no líquido, observa-se também a existência de três regiões distintas. Cada uma destas regiões consistirá em um diferente estágio na redistribuição do soluto e terá um perfil de concentração específico. Estas regiões são denominadas de Transiente Inicial, Estado Estacionário e Transiente Final.

\subsection{Transiente Inicial}

Durante um processo de solidificação direcional com uma interface sólido/líquido plana em um equipamento do tipo Bridgman, antes que ocorra o estado estacionário, existe uma determinada distância denominada de transiente inicial, como mostra a Figura 3, onde $\mathrm{C}_{0} \mathrm{k}$ é a concentração do primeiro sólido a se formar e $\mathrm{C}_{0} / \mathrm{k}$ é a concentração máxima no líquido a frente da interface.

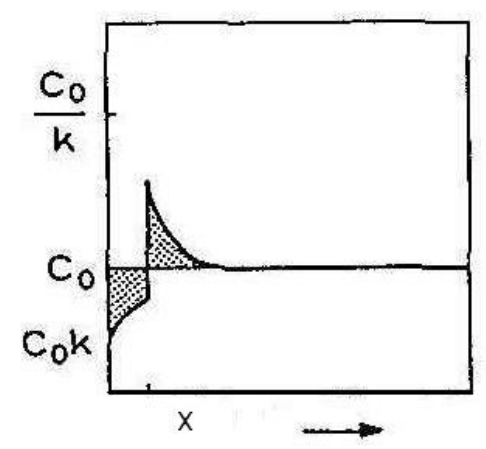

Figura 3 - Transiente inicial em um processo de solidificação. [KURZ, 1989].

Isto ocorre pelo fato de que, no início da solidificação, o soluto é rejeitado do sólido inicial que se forma, mas pelos baixíssimos valores de gradiente de concentração no líquido, esse soluto não é transportado ao seio da fase líquida, ficando acumulado junto à interface e sendo, posteriormente, solidificado. Na medida em que o processo avança, mais soluto vai se acumulando e, com isso, o gradiente 
de concentração aumenta possibilitando um transporte de massa mais intenso de soluto para o seio da fase líquida. Com a continuidade desse processo, atinge-se um valor de gradiente que permite o transporte de massa de todo o soluto que é rejeitado pela fase sólida. Quando isso ocorre o estado estacionário foi então atingido. O perfil de concentração de soluto no sólido durante o transiente inicial pode ser calculado pela equação [TILLER et al,1953]:

$$
C_{S}=C_{0}\left\{(1-k)\left[1-\exp \left(-k \frac{V}{D} z\right)\right]+k\right\}
$$

onde $\mathrm{V}$ é a velocidade de avanço da interface sólido/líquido, D é o coeficiente de difusão de soluto no líquido, z é a distância até a interface sólido/líquido. Esta equação é válida para sistemas sem convecção no líquido e sem difusão no sólido, e com baixos valores de coeficiente de partição.

\subsection{Estado Estacionário}

A Figura 4 mostra a redistribuição de soluto no estado estacionário. Tiller et al. (1953) propuseram um modelo matemático pioneiro para o perfil de concentração de soluto no líquido à frente de uma interface sólido-líquido plana em crescimento. Neste modelo foi assumido: transporte de massa unidirecional na direção perpendicular à interface; velocidade de crescimento constante; estado estacionário para um referencial fixo na interface sólido-líquido; transporte de soluto no líquido apenas por difusão (convecção desprezível); transporte de soluto no sólido inexistente e liga binária. 


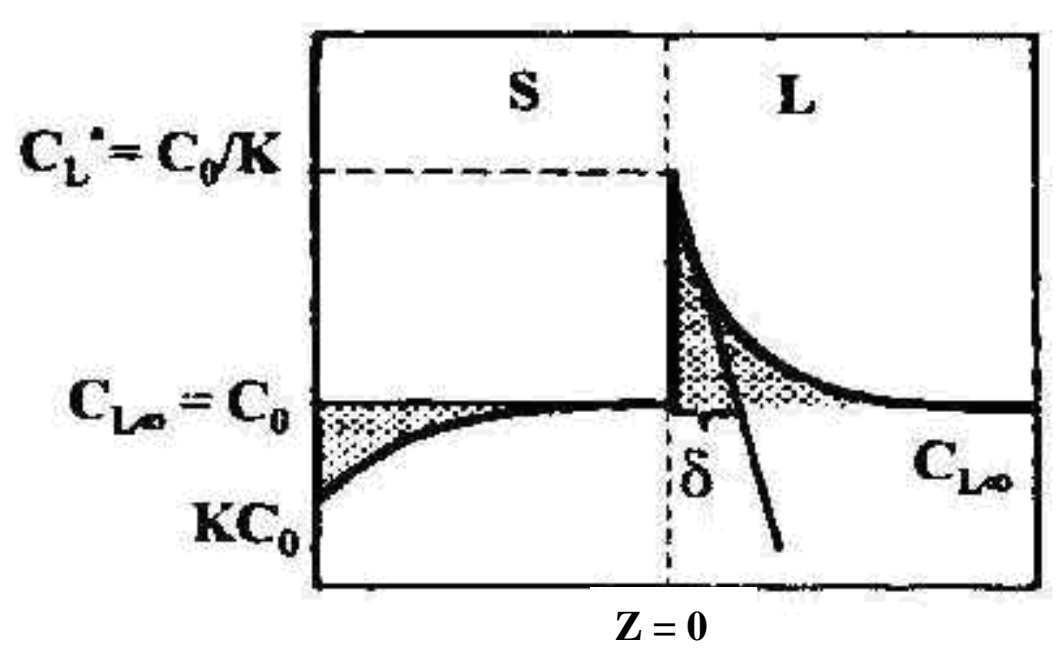

Figura 4 - Estado estacionário em um processo de solidificação considerando transporte de soluto por difusão no líquido e sem difusão no sólido. [KURZ, 1989]

A seguinte equação foi obtida para o perfil de concentrações no líquido:

$$
C_{I}=C_{I}^{\infty}\left[\frac{k+(1-k) \exp \left(-\frac{z V}{D}\right)}{k}\right]
$$

onde z é a coordenada ao longo da direção de crescimento, sendo que $z=0$ é a posição da interface sólido-líquido. Utilizando este perfil, pode-se calcular $\mathrm{dC} / \mathrm{dz}$ na interface e obter-se a distância efetiva de difusão através da equação [5], resultando em

$$
\delta=\frac{D}{V}
$$

A equação [7] fornece o perfil de concentração de soluto no líquido à frente da interface sólido-líquido após o sistema atingir estado-estacionário. Neste caso, a concentração do sólido permanece constante com o tempo, sendo igual à concentração do líquido longe da interface, $\mathrm{C}_{\mid}^{\infty}$, não resultando em macrossegregação ou efeito de refino ao longo do lingote. 


\subsection{Transiente Final}

Uma vez que o estado estacionário tenha sido atingido, ele se manterá enquanto forem satisfeitas as seguintes condições: exista líquido suficiente adiante da interface para que o transporte do soluto para o seio do líquido ocorra sem impedimentos, e $V$ permaneça constante. É evidente que a concentração de sólido eleva-se para um valor maior que $\mathrm{C}_{0}$ de modo a acomodar o excesso de soluto que deve se concentrar na região final.

Para que os princípios de conservação de massa sejam satisfeitos, é necessário que as áreas escuras (I e III na Figura 5) referentes ao transiente inicial e final sejam iguais.

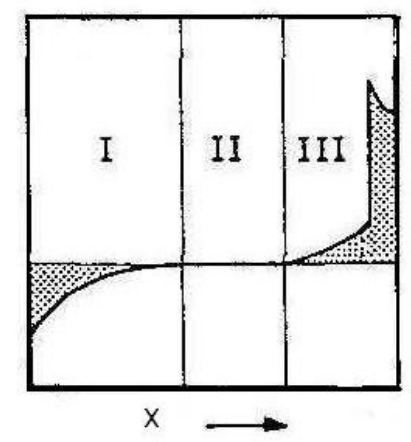

Figura 5 - Transiente final em um processo de solidificação [KURZ, 1989]

\subsubsection{Análise Teórica do Efeito da Convecção no Transporte de Massa}

Um importante processo de solidificação direcional controlada é aquele conduzido em um forno do tipo Bridgman [KURZ e FISHER, 1989]. Neste forno, o gradiente de temperatura e a velocidade de solidificação podem ser controlados separadamente. Este tipo de controle possibilita a imposição de condições experimentais que favorecem certos tipos de morfologia da interface sólido-líquido, como a morfologia plana.

Quando o transporte de soluto no líquido por difusão ou convecção for suficientemente rápido para tornar o gradiente de concentração desprezível e quando não houver transporte de soluto no sólido, o modelo originalmente proposto por Scheil (1942) pode ser utilizado para calcular a concentração do sólido ao longo 
do lingote. Este modelo indica que a concentração de soluto no sólido $\mathrm{C}_{\mathrm{S}}$ em função da distância z ao longo do lingote é dada por [SCHEIL, 1942]

$$
C_{S}=k \cdot C_{0}\left(1-\frac{z}{L}\right)^{(k-1)}
$$

onde $\mathrm{C}_{0}$ é a concentração inicial de soluto e $\mathrm{L}$ é o comprimento total do lingote na direção de crescimento.

Burton, Prim e Slichter (BPS) (1953) propuseram um modelo analítico aproximado para a redistribuição de soluto na presença de convecção no líquido quando este não é totalmente homogêneo. Como principais hipóteses, os autores assumiram que: (a) no interior de uma camada de líquido de espessura $\delta_{\mathrm{BPS}}$ adjacente à interface, o transporte de soluto ocorre apenas por difusão; (b) nesta camada pode-se considerar estado quase-estacionário para um referencial fixo na interface sólido-líquido e (c) fora desta camada a convecção torna o líquido completamente homogêneo. Segundo este modelo, o perfil de concentrações no líquido interno a esta camada é dado por

$$
C_{l}=C_{l}^{\infty}\left[\frac{k+(1-k) \exp \left(-\frac{z V}{D}\right)}{k+(1-k) \exp \left(-\frac{\delta_{B P S} V}{D}\right)}\right]
$$

A Figura 6 abaixo mostra um esquema da camada de difusão segundo o modelo desenvolvido por Burton, Prim e Slichter.

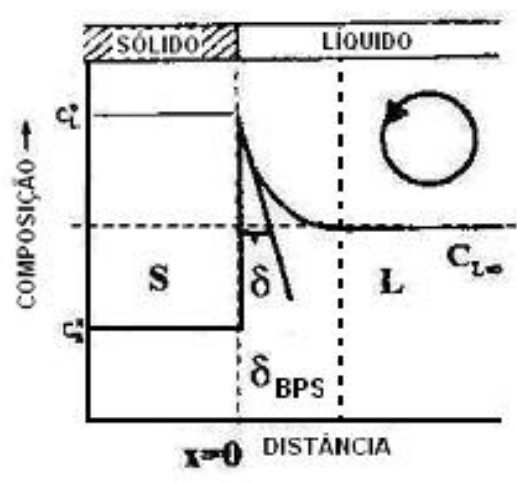

Figura 6 - Representação da camada $\delta_{\mathrm{BPS}}$ considerando transporte de soluto por convecção no líquido e sem difusão no sólido. [MARTORANO, 2005] 
Deve-se notar que, quando $\delta_{\mathrm{BPS}} \rightarrow \infty$ (e não quando $\delta_{\mathrm{BPS}} \rightarrow \delta$ ), a equação [10] tende a equação [7], desenvolvida para o caso onde não há convecção, ou seja, todo o fluido está contido na camada $\delta_{\mathrm{BPS}}$. Utilizando este perfil, também é possível calcular uma distância efetiva de difusão, que será denominada $\delta$, através da equação [5], possibilitando o cálculo do parâmetro convectivo-difusivo como será mostrado em um item subseqüente.

O coeficiente de partição de soluto $k$ foi definido pela equação [4] para uma situação onde o sólido e líquido estão em equilíbrio a uma dada temperatura. No intuito de facilitar o tratamento dos problemas de transporte de massa na presença de convecção, Burton, Prim e Slichter [1953] propuseram um coeficiente de partição efetivo, $k_{\text {eff }}$, definido como

$$
k_{\text {eff }}=\frac{C_{s}^{*}}{C_{l}^{\infty}}
$$

onde $\mathrm{C}_{\mathrm{s}}{ }^{*}$ é a concentração de soluto do sólido junto à interface sólido-líquido e $\mathrm{C}_{\mid}^{\infty}$ é a concentração de soluto no líquido distante da interface.

Nas condições do modelo BPS é possível relacionar $k$ e $k_{\text {eff }}$ calculando-se a concentração no líquido junto á interface, $\mathrm{C}_{\mathrm{s}}{ }^{*}$, e longe da mesma, $\mathrm{C}_{\mid}^{\infty}$, através da equação [9]. Esta relação é dada como [BURTON, PRIM e SLICHTER, 1953]

$$
k_{\text {eff }}=\frac{k}{k+(1-k) \exp \left(-\frac{\delta_{B P S} V}{D}\right)}
$$

Note que quando o líquido é homogêneo devido ao efeito de convecção, $k_{\text {eff }}=k$, porém quando se tem o regime de transporte difusivo, $k_{\text {eff }}=1$. Este caso representa o estado estacionário discutido anteriormente, onde a concentração no sólido junto à interface $\left(\mathrm{C}_{\mathrm{s}}{ }^{*}\right)$ é igual à concentração do líquido distante da mesma $\left(\mathrm{C}_{1}^{\infty}\right)$.

Como o modelo BPS assume que o líquido é homogêneo fora da camada de espessura $\delta_{\mathrm{BPS}}$, a equação [9] (modelo de Scheil) pode ser utilizada para prever o perfil de concentrações no sólido ao longo da direção de crescimento substituindo-se $k$ por $k_{\text {eff. }}$ A nova equação seria 


$$
C_{s}=k_{\text {eff }} \cdot C_{0}\left(1-\frac{z}{L}\right)^{\left(k_{\text {eff }}-1\right)}
$$

Esta equação tem grande utilidade em problemas de engenharia, pois é possível calcular a macrossegregação no lingote conhecendo-se a espessura da camada efetiva de difusão em uma dada situação $(\delta)$ e utilizando-se as equações [12] e [13] já vistas e a equação [16] que será vista posteriormente. As espessuras $\delta$ ou $\delta_{\text {BPs }}$ e conseqüentemente $k_{\text {eff }}$ estão diretamente relacionados com a fluidodinâmica específica de cada processo. Estes parâmetros podem ser medidos ou calculados através de modelos matemáticos específicos.

O transporte de massa durante a solidificação direcional de ligas metálicas em forno Bridgman vem sendo estudado desde os anos 50, com o início da produção de monocristais de Si para a indústria eletrônica. Um dos principais objetivos destes estudos foi a previsão da macrossegregação de soluto. De forma geral, a macrossegregação é gerada através do transporte de soluto no líquido durante a solidificação. A velocidade de crescimento de uma interface sólido-líquido plana está relacionada com o fluxo de soluto rejeitado através da condição de Stefan para o transporte de massa, definida abaixo para o caso unidirecional [CRANK, 1984]

$$
-\left.D \frac{\partial C_{l}}{\partial z}\right|_{z=z_{i}}=V(1-k) C_{l}^{*}
$$

Deve-se enfatizar que esta condição é válida mesmo em situações onde o transporte de soluto no líquido é auxiliado por correntes de convecção, desde que as densidades do líquido e sólido sejam iguais.

Ao combinar as equações [5] e [14], tem-se:

$$
\Delta=\frac{\delta D}{V}=\frac{C_{l}^{*}-C_{I}^{\infty}}{(1-k) C_{I}^{*}}
$$

onde $\Delta$, definido por Burton, Prim e Slichter [1953], é chamado de parâmetro convectivo-difusivo. Como será mostrado adiante, $\Delta$ representa a taxa entre a 
distância efetiva de difusão no sistema (com ou sem convecção no líquido) e a distância efetiva de difusão quando não há convecção no líquido.

Uma outra forma de representar o parâmetro convectivo-difusivo é:

$$
\Delta=\frac{\delta V}{D}=1-\exp \left(-\frac{\delta_{B P S} V}{D}\right)
$$

Consistente com os comentários anteriores, quando $\delta_{\mathrm{BPS}} \rightarrow \infty$, a distância efetiva de difusão $\delta \rightarrow V / D$ e $\Delta \rightarrow 1$. Por outro lado, quando a convecção é extremamente vigorosa e $\delta_{\mathrm{BPS}} \rightarrow 0$, a distância efetiva de difusão $\delta \rightarrow 0$, e $\Delta \rightarrow 0$, ou alternativamente $\Delta<<1$. É interessante notar que $\Delta$ depende não só da espessura da camada de difusão efetiva, mas também da velocidade de crescimento da interface $\mathrm{V}(\Delta=\delta \mathrm{V} / \mathrm{D})$. Desta forma, mantendo as condições de convecção constantes, um aumento da velocidade de crescimento deve diminuir o efeito da convecção no perfil de macrossegregação final [FLEMINGS, 1974], porque $\Delta$ aumentaria. Por outro lado, uma diminuição da velocidade de crescimento deve aproximar o perfil de concentrações daquele fornecido pelo modelo de Scheil [CHALMERS, 1964].

Desta forma, os parâmetros de processo importantes para definir o tipo de transporte de soluto no líquido, definindo o perfil de macrossegregação final no sólido, são as condições convectivas e a velocidade de crescimento (V). É então possível definir dois tipos de regime de transporte de massa [GARANDET et al., 1994]:

- regime difusivo $(\Delta \approx 1)$ : o transporte de soluto ocorre basicamente por difusão no líquido e a convecção é desprezível, resultando em um transiente inicial seguido do estado estacionário;

- regime convectivo $(\Delta<<1)$ : o transporte de soluto ocorre por convecção no líquido, que possui concentração homogênea, resultando em um perfil de concentração no sólido dado pelo modelo de Scheil [1942]. 


\subsubsection{Análise Experimental do Transporte de Massa na Solidificação Controlada}

Existem poucos estudos do transporte de massa na solidificação direcional do tipo Bridgman visando a purificação do silício. No presente item inicialmente serão apresentados alguns resultados em outros sistemas, nos quais foram formuladas conclusões gerais sobre a transferência de massa durante a solidificação direcional controlada. Em seguida serão apresentados os poucos trabalhos realizados com o silício.

Yue e Clark (1960) obtiveram o coeficiente de partição efetivo ( $\left.K_{\text {eff }}\right)$ na solidificação direcional horizontal de ligas binárias de $\mathrm{Mg}-(\mathrm{Cu}, \mathrm{Ni}, \mathrm{Zn})$. Os perfis de concentração de soluto no sólido após a solidificação apresentaram grande semelhança com o perfil dado pelo modelo de Scheil [1942], indicando a presença de mistura completa no líquido devido à convecção natural, geralmente presente no forno horizontal. Ajustando o modelo de Scheil aos perfis experimentais, foi possível medir o coeficiente de partição efetivo $k_{\text {eff. }}$ Observou-se que este coeficiente diminuiu com o decréscimo da velocidade de crescimento, tendendo ao coeficiente de partição k, obtido a partir do diagrama de fases. Estes resultados reforçam as conclusões obtidas a partir da teoria discutida anteriormente: a redução da velocidade de crescimento, mantendo as condições de convecção constante, deve aumentar o efeito de mistura no líquido.

Dean et al. [1961-62] estudaram a redistribuição de soluto na solidificação direcional da liga $\mathrm{Pb}-1 \% \mathrm{Sb}$ em um forno do tipo Bridgman horizontal e obtiveram $\mathrm{k}_{\text {eff }}$ ajustando os perfis de concentração ao modelo de Scheil. Diversos valores de $k_{\text {eff }}$ foram calculados em função da velocidade de crescimento. Quando estas velocidades são relativamente pequenas, nota-se um comportamento semelhante ao observado por Yue e Clark [1960], ou seja, um aumento de $k_{\text {eff }}$ com o aumento da velocidade. Entretanto, acima de um determinado valor de velocidade, $\mathrm{k}_{\mathrm{eff}}$ aumentou bruscamente para 1, permanecendo aproximadamente constante. Os autores mostraram que o brusco aumento de $\mathrm{k}_{\text {eff }}$ estava associado à mudança de morfologia da interface sólido-líquido de plana para uma morfologia celular ou dendrítica. Conseqüentemente, nestas condições a macrossegregação é praticamente inexistente. 
Weinberg [1963] estudou a solidificação direcional de ligas binárias à base de Sn contendo um entre diversos tipos de soluto, a saber, $\mathrm{Ag}$, In ou Bi. Os ensaios foram realizados em fornos do tipo Bridgman horizontal e vertical. Os efeitos da velocidade de crescimento, gradiente de temperatura, diâmetro do cadinho utilizado para a solidificação, direção de solidificação (vertical ou horizontal), entre outras variáveis, foram analisados nos perfis de concentração ao longo das amostras. Os perfis foram medidos em amostras resfriadas bruscamente em diversos instantes durante a solidificação direcional. O objetivo do resfriamento era manter estes perfis de concentração inalterados na região que era líquida antes do resfriamento. Desta forma, foi possível analisar a variação de concentração na porção sólida e líquida das amostras. Na extensa gama de condições experimentais testadas, observou-se que o perfil de concentrações no líquido variou do caso de mistura difusiva ao caso de mistura completa no líquido. Os autores obtiveram o coeficiente de difusão efetivo no líquido e $k_{\text {eff }}$ ajustando o modelo de Smith et al. [1955] aos perfis obtidos experimentalmente. Concluiu-se que um aumento do diâmetro do cadinho que continha o metal e uma diminuição da velocidade de crescimento aumentava o efeito de mistura no líquido.

Schievenbusch e Zimmermann [1995b] e Zimmermann et al. [1996] estudaram a solidificação direcional de ligas Cu-Mn em um forno do tipo Bridgman vertical (solidificação ascendente). Como realizado por Weinberg [1963], as amostras foram resfriadas bruscamente durante a solidificação com o objetivo de preservar o perfil de concentrações no líquido no instante do resfriamento. Os perfis de concentração medidos na região líquida antes do resfriamento foram ajustados a uma curva de variação exponencial com a distância. A partir destes perfis, calcularam-se as distâncias efetivas de difusão $\delta$ em cada situação experimental. Zimmerman et al. [1996] mostraram que os valores de $\delta$ medidos experimentalmente para a liga Cu-38\%Mn ajustavam-se perfeitamente aos valores calculados para 0 caso sem convecção $\left(\delta_{D}\right)$, dados pela equação [8]. No entanto, os valores de $\delta$ experimentais foram sempre menores do que $\delta_{\mathrm{D}}$ para a liga $\mathrm{Cu}-30 \% \mathrm{Mn}$, indicando a presença de convecção no líquido. Estes resultados estão consistentes com o fato de que, na liga Cu-38\%Mn, o líquido junto à interface é mais denso do que o líquido de composição média, não existindo convecção natural movida por gradientes de concentração. Na liga Cu-30\%Mn, entretanto, o líquido é menos denso e existe a 
possibilidade de uma desestabilização causando a presença de correntes de convecção. Esta hipótese foi reforçada por Schievenbusch e Zimmermann [1995b] após ensaios sob a ação de microgravidade, verificando que $\delta$ tendia ao valor do caso difusivo. Assim como mostrado por Yue e Clark [1960] e Dean et al. [1961-62], os autores mostraram que $k_{\text {eff }}$ aumentava com 0 aumento da velocidade de crescimento.

Diversos autores mediram a espessura efetiva de difusão $\delta$ durante a solidificação de várias ligas em algumas situações experimentais [FLEMINGS ,1974]. Nota-se que $\delta$ pode variar de até três ordens de grandeza no processo Bridgman, refletindo a dependência destes valores nos detalhes específicos do processo e nas ligas estudadas. Deve-se enfatizar ainda que não há dados experimentais de distância efetiva de difusão $(\delta)$ ou coeficiente efetivo de partição ( $\left.k_{\text {eff }}\right)$ na solidificação direcional Bridgman visando a purificação de silício.

Existem inúmeros estudos sobre a solidificação direcional para obtenção dos cristais de Si isentos de defeitos e segregação [ZULEHNER, 2000; MÜLLER, 1988], como a solidificação Czochralski. Entretanto há poucos trabalhos que visam especificamente a purificação do silício a partir do SiGM utilizando propositalmente um mecanismo de segregação. Bolzan et al. [1984] examinaram refino de SiGM e SiR (silício refinado por lixiviação ácida) através da solidificação direcional o tipo Bridgman vertical. O teor de impurezas foi analisado ao longo dos lingotes purificados, entretanto, somente os elementos que estavam em teores acima do limite de detecção da técnica de análise química utilizada ( $\mathrm{Al}$, B e $\mathrm{P}$ ) permitiram a construção perfis de concentração ao longo do lingote. Geralmente os elementos presentes em teores mais elevados não são aqueles que se desejam eliminar com a solidificação direcional, porque é necessário utilizar algum outro processo de refino. Apenas uma condição experimental foi estudada neste trabalho e os perfis obtidos não foram comparados com modelos matemáticos para a obtenção de parâmetros importantes, como o coeficiente de partição efetivo ( $\left.k_{\text {eff }}\right)$.

Revel et al. [1987] estudaram o refino do SiGMU (silício grau metalúrgico purificado) e de um SIGE ao qual foram adicionadas propositalmente as impurezas: $\mathrm{Al}, \mathrm{B}, \mathrm{C}$ e Cu. Os autores obtiveram $\mathrm{k}_{\text {eff }}=0,81$ e $\mathrm{k}_{\text {eff }}=4 \times 10^{-3}$ para $\circ \mathrm{B}$ e $\mathrm{Al}$, respectivamente. Estes valores estão próximos aos coeficientes de partição de soluto $\mathrm{k}$, que são 0,81 e $2 \times 10^{-3}$, respectivamente. Os resultados parecem indicar um 
regime de mistura completa no líquido, entretanto nenhum perfil de concentrações foi fornecido para qualquer elemento.

Yuge et al. [2001] estudaram a purificação do SiGM utilizando uma seqüência composta por remoção de boro utilizando um forno de feixe de elétrons seguido por uma solidificação direcional. Na seqüência, o material era submetido a um forno de plasma para remoção de fósforo e submetido novamente a uma solidificação direcional. A solidificação direcional foi realizada em um cadinho sem o controle independente da velocidade e gradiente de temperatura usualmente obtido no forno tipo Bridgman. Os perfis de concentração do Fe, Al e Ti foram apresentados e mostraram valores na ordem de 0,01 ppm.

\subsection{Morfologia da Interface Sólido-Líquido}

\subsubsection{Super Resfriamento Constitucional}

O líquido que se encontra em contato com a interface sólido/líquido possui uma concentração que geralmente difere da concentração existente no seio da fase líquida. Se o coeficiente de partição de soluto for menor que 1, o soluto será segregado para a fase líquida e, caso haja acúmulo de soluto junto à interface, a temperatura liquidus do líquido em contato com a mesma será menor do que a do líquido distante da interface [CHALMERS, 1964].

O perfil de temperatura no líquido é representado pela Figura 7, que corresponde ao caso no qual todo o líquido está a uma temperatura acima da temperatura da interface, no entanto o líquido está super-resfriado no sentido de que está abaixo da temperatura liquidus. Tal super-resfriamento é denominado de "Super-resfriamento Constitucional" [CHALMERS, 1964], onde o termo "constitucional" indica que o super-resfriamento advém de uma mudança de composição e não de temperatura. 


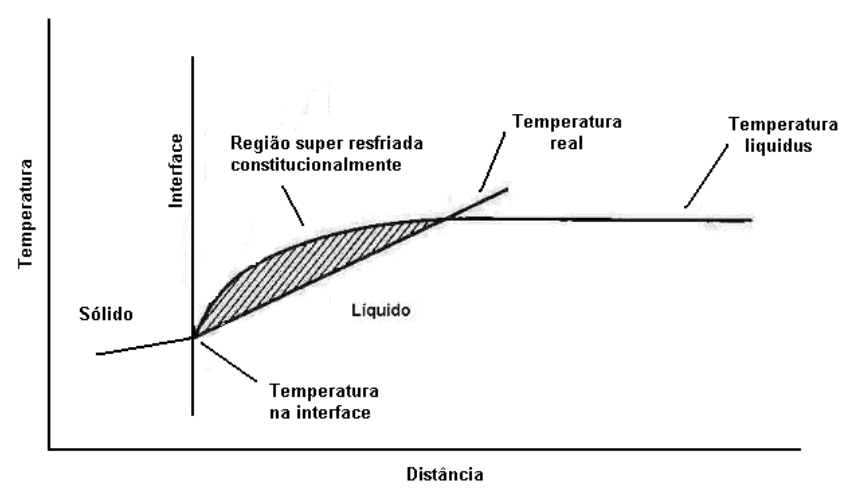

Figura 7 - Super-resfriamento à frente de uma interface S/L. [CHALMERS, 1964]

3.4.2 Instabilidade da Interface devido ao Super-resfriamento Constitucional

Durante a solidificação de uma liga, existe uma mudança de concentração no líquido junto à interface que pode acarretar uma diminuição da temperatura liquidus à frente da interface como se pode observar pela relação [FLEMINGS, 1974]:

$$
T_{l}\left(C_{0}\right)-T_{l}=m\left(C_{0}-C_{l}\right)
$$

onde $T_{l}\left(C_{0}\right)$ é a temperatura liquidus correspondente a composição inicial da liga e m é a inclinação da linha liquidus.

A Figura 8 abaixo mostra as condições necessárias para o desenvolvimento de instabilidade em uma interface plana. A Figura 8c mostra uma condição onde cada ponto a frente da interface se encontra acima da temperatura liquidus. Esta condição é a necessária para o estabelecimento de uma interface sólido/líquido plana. Caso alguma instabilidade provoque uma protuberância na interface plana, esta mesma protuberância se encontrará em um meio superaquecido e, por isso, voltará ao estado líquido, e a morfologia da interface sólido/líquido permanecerá plana. 


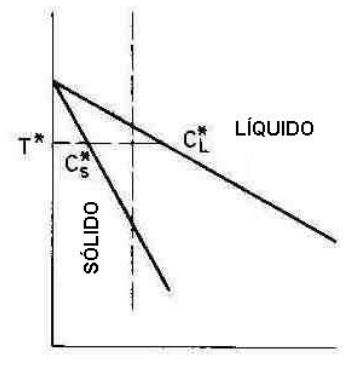

(a)

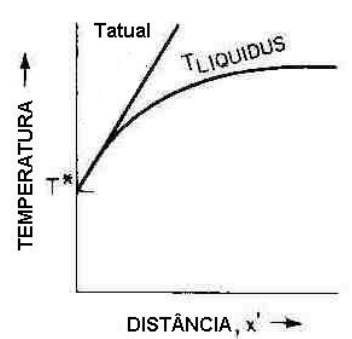

(c)

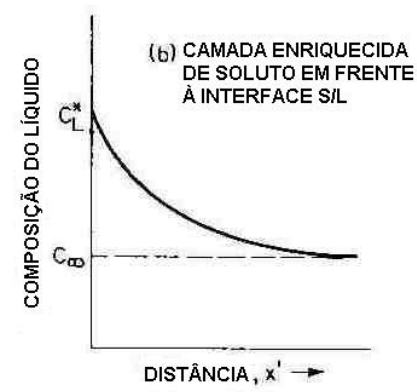

(b)

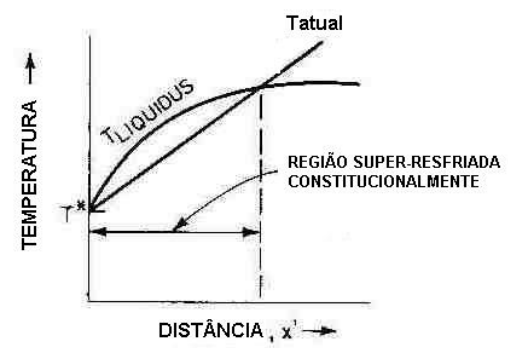

(d)

Figura 8 - Super-resfriamento Constitucional na solidificação de uma liga. (a) Diagrama de fase; (b) camada enriquecida de soluto em frente à interface $S / L$; (c) interface estável; (d) interface instável. [FLEMINGS, 1974]

A Figura 8d, por outro lado, representa esquematicamente o caso de uma interface instável. Aqui, o líquido à frente da interface se encontra a uma temperatura abaixo da temperatura liquidus, e é, por isso, um líquido super-resfriado. Essa circunstância promoverá condições para o crescimento de protuberâncias na interface sólido-líquido.

A análise realizada no parágrafo anterior leva ao estabelecimento de um importante critério para a determinação da morfologia da interface sólido/líquido para ligas binárias e é denominado de "Critério do Super-resfriamento Constitucional" representado pela Eq. 18 [CHALMERS, 1964].

Para que não ocorra o super-resfriamento constitucional, é necessário que o gradiente de temperatura real no líquido à frente da interface $\left(G_{\llcorner}\right)$seja maior ou igual ao gradiente de temperatura liquidus na interface, ou seja:

$$
G_{L}=\left(\frac{d T_{R}}{d x}\right)_{x=0} \geq\left(\frac{d T_{l i q}}{d x}\right)_{x=0}
$$


Logo, pode-se escrever a seguinte relação

$$
\frac{G_{L}}{V} \geq \frac{-m C_{S i}(1-k)}{D k}
$$

A equação acima pode ser utilizada tanto na presença quanto na ausência de convecção. As equações acima descritas representam de forma quantitativa 0 critério do super-resfriamento constitucional e também permite definir as condições que favorecem seu surgimento. Pela observação da equação acima nota-se que um aumento da velocidade da interface e/ou uma diminuição no gradiente térmico no líquido favorecem o super-resfriamento constitucional. [FLEMINGS, 1974]

Desde sua formulação, em 1953, foram apresentadas várias comparações qualitativas e quantitativas validando o critério do super-resfriamento constitucional. Em estudos com materiais transparentes inorgânicos foi observado o surgimento de ondulações e posterior formação de uma estrutura celular na interface sólido/líquido com a diminuição de $G_{L} / R$ [JACKSON e HUNT, 1965]. Walton et al. [WALTON, 1955] estudaram a solidificação de uma liga Sn-Pb em uma barqueta horizontal sob várias condições térmicas e examinaram a interface sólido/líquido após decantação. Em seguida, substituindo o valor de $k$ e $m_{L}$ na equação [19], encontraram $D$ igual a 2 $\times 10^{-5} \mathrm{~cm}^{2} / \mathrm{s}$. Hunt et al. [HUNT, 1968] também obtiveram um resultado similar $(1,12 \mathrm{x}$ $10^{-5} \mathrm{~cm}^{2} / \mathrm{s}$ ) em um sistema com agitação no líquido e utilizando a mesma liga $\mathrm{Sn}-\mathrm{Pb}$. Ambos os resultados são próximos aos encontrados na literatura [FLEMINGS, 1974].

Os experimentos relacionados acima indicam que o critério do superresfriamento constitucional prediz as condições necessárias para o estabelecimento de uma interface sólido/líquido plana em processos de solidificação de metais.

\subsubsection{Ligas Multicomponentes}

Ligas multicomponentes também podem solidificar com interface sólido/líquido plana, assim como ligas binárias. As teorias da instabilidade da interface e do super-resfriamento constitucional aplicam-se também a ligas multicomponentes. Semelhante ao caso binário, a condição para estabilidade da interface plana é de que o gradiente da temperatura real à frente da interface seja 
maior ou igual ao gradiente de temperatura liquidus. O fator que mais diferencia os dois casos é que, no caso multicomponente, em lugar da linha liquidus utiliza-se a superfície liquidus e a difusão pode ocorrer para os diferentes solutos.

A distribuição dos solutos $m$ e $n$ em um solvente $q$ à frente da interface sólido/líquido de uma liga ternária, em estado estacionário é mostrada na Figura 9 . É importante mencionar que a camada limite de difusão não terá o mesmo tamanho para ambos os solutos devido aos diferentes coeficientes de difusão.

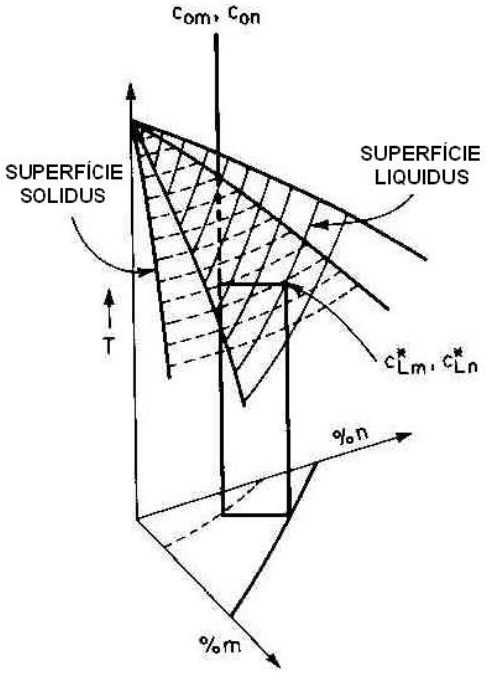

(a)

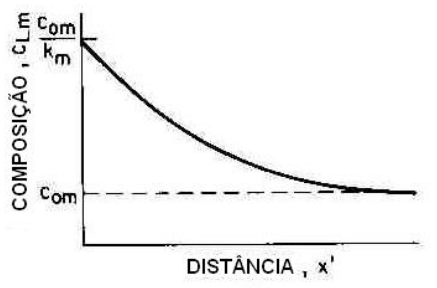

(b)

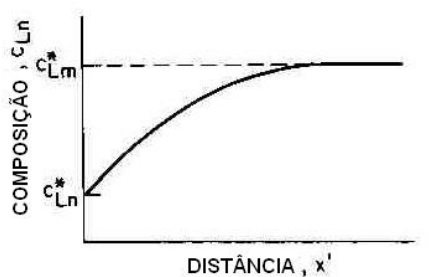

(c)

Figura 9 - Representação de um diagrama de fases ternário e perfis de concentração de soluto no líquido na direção perpendicular á interface sólido-líquido para os solutos: (a) m e (b) n [FLEMINGS, 1974]

O critério de super-resfriamento constitucional para ligas ternárias é:

$$
\frac{G_{L}}{V} \geq-\frac{p\left(C_{L m}^{*}-C_{0 m}\right)}{D_{m m}}-\frac{s\left(C_{L m}^{*}-C_{0 n}\right)}{D_{n n}}
$$

A equação [20] pode ser reescrita na seguinte forma: 


$$
\frac{G_{L}}{V} \geq-\frac{p C_{0 m}\left(1-k_{m}\right)}{k_{m} D_{m m}}-\frac{s C_{0 n}\left(1-k_{n}\right)}{k_{n} D_{n n}}
$$

onde $k_{m}$ e $k_{n}$ são os coeficientes de partição dos solutos $m$ e $n$, respectivamente, definidos como no caso binário e $p$ e s são as inclinações da linha liquidus para os solutos $m$ e $n$. A equação 21 é mais difícil de se aplicar devido à dificuldade de se obter os coeficientes de partição. Para isto é necessário que as linhas de isoatividades ("tie-lines") dos diagramas de fases ternários sejam conhecidas, mas estas têm sido determinados apenas para alguns sistemas. Entretanto, se as superfícies liquidus e solidus são planas, então $K_{m}, K_{n}, p$ e s serão todos constantes e podem ser determinados por um par de diagramas de fase apropriado.

Cole e Winegard [1963] estudando um sistema ternário composto por Sn-Pb$\mathrm{Sb}$ encontraram uma boa concordância quantitativa com a equação [21]. Foi observado que um aumento nas quantidades de $\mathrm{Pb}$ e $\mathrm{Sb}$ exigia um maior valor de $\left(G_{\llcorner} / V\right)$ para a manutenção da estabilidade da interface. 
CAPÍTULO 4

\section{MATERIAIS E MÉTODOS}




\subsection{MATERIAIS E MÉTODOS}

A seguir será apresentado todo o procedimento experimental utilizado para os ensaios do refino do silício por solidificação direcional realizado neste trabalho. A partir destes ensaios, obtiveram-se diversas amostras que foram caracterizadas quanto à sua macro/microestrutura e composição química segundo a metodologia descrita também neste item.

Durante cada ensaio de solidificação direcional, todas as variáveis de processamento foram mantidas constantes, porém uma variável foi alterada de ensaio para ensaio. As variáveis alteradas visando cumprir os objetivos do presente trabalho foram: a velocidade de extração do molde para fora da região de alta temperatura do forno e o nível de pureza (composição inicial) do silício introduzido no forno. A velocidade de extração e a composição inicial foram escolhidas como variáveis para o estudo por existirem diversas evidências em outros sistemas de ligas do seu importante efeito no perfil de concentrações final ao longo dos lingotes e na morfologia da interface sólido-líquido [YUE e CLARK, 1960; WEINBERG, 1963; ZIMMERMANN et al., 1996; SCHIEVENBUSCH et al.,1995b].

\subsection{Metodologia do Ensaio de Solidificação Direcional Controlada}

Trinta ensaios de solidificação direcional controlada foram realizados em duas etapas, uma de ensaios preliminares e outra de ensaios definitivos. Estes ensaios foram conduzidos em um forno de indução a vácuo do tipo Bridgman contendo uma câmara de fusão e outra para a solidificação direcional. A Figura 10(a) mostra uma ilustração do forno empregado, localizado no Instituto de Pesquisas Tecnológicas de São Paulo (IPT).

Cada um dos ensaios preliminares e definitivos foi executado em duas etapas: uma de fusão e outra de solidificação. Na etapa de fusão (primeira etapa), cargas de silício eram depositadas em um cadinho de grafita de alta pureza ou de quartzo grau solar (descritos no item 4.2) localizado no interior da câmara de fusão (Figura 10(b)). O forno era fechado e o aquecimento iniciado. Durante aquecimento, 
uma bomba de vácuo mecânica era acionada, resultando em uma pressão de $\cong 10^{-2}$ torr e removendo uma eventual umidade residual do sistema. Posteriormente, argônio ultrapuro $(99,999 \%)$ era introduzido no interior do forno até que este atingisse uma pressão de 500 torr. Esta pressão era mantida durante todo o tempo restante de ensaio para diminuir a interação entre o Si líquido após fusão e o material do molde $\left(\mathrm{SiO}_{2}\right)$ segundo a reação:

$$
\mathrm{SiO}_{2}(\mathrm{~s})+\mathrm{Si}(\mathrm{I})=2 \mathrm{SiO}(\mathrm{g})
$$

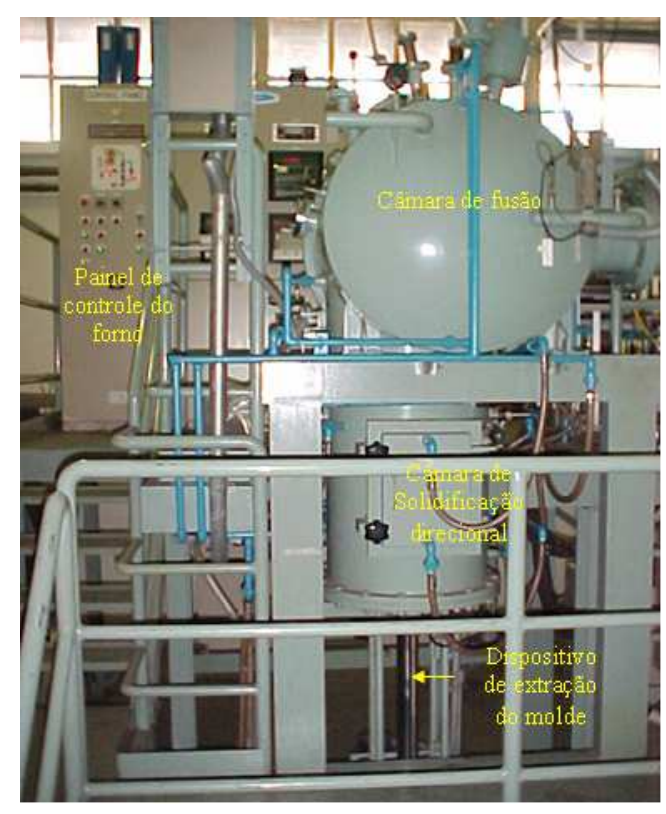

(a)

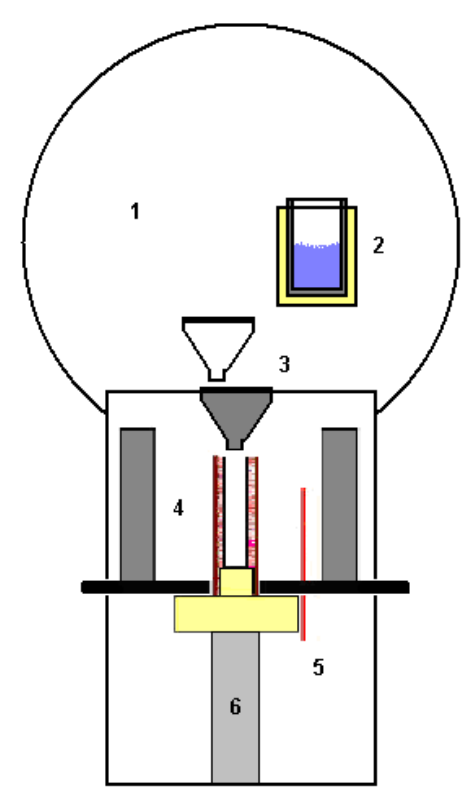

(b)

Figura 10 - Forno vertical do tipo Bridgman utilizado nos ensaios de solidificação direcional ascendente: (a) visão frontal do forno; (b) desenho esquemático do interior do forno: 1 - câmara de fusão; 2 - cadinho de fusão; 3 - conjunto de funis; 4 - zona aquecida; 5 - zona fria (câmara de solidificação); 6 - elevador.

Após a fusão do silício, o cadinho era basculado e o silício líquido vazado para um molde de quartzo localizado no interior da câmara de solidificação direcional. O vazamento era auxiliado por funis constituídos ou de grafita ou de quartzo grau solar (Figura 10(b)). O molde de quartzo, alojado no interior de um susceptor de grafita concêntrico a uma bobina de aquecimento indutivo, era estabilizado durante $45 \mathrm{~min}$ a uma temperatura de $1500 \pm 5^{\circ} \mathrm{C}$, controlada através de um termopar fixo ao lado do susceptor (Figura 10(b)). 
Após estabilização da temperatura, o molde era extraído da zona onde se encontrava o susceptor de grafita a uma velocidade previamente ajustada e controlada automaticamente pelo sistema elétrico do forno. Essa forma de extração permitiu o crescimento de grãos colunares na direção e sentido do gradiente térmico, resultando em uma solidificação vertical ascendente. O ensaio era terminado após a completa extração do molde, finalizando a solidificação do silício. Após resfriamento até a temperatura ambiente, o molde de quartzo era quebrado e o lingote retirado para caracterização química e macro-microestrutural.

\subsection{Montagem do Molde para Solidificação Direcional}

O molde utilizado para a solidificação direcional, localizado no interior da câmara de solidificação do forno, foi constituído basicamente de uma montagem com um tubo de quartzo que servia como recipiente ao metal líquido. $O$ tubo de quartzo era inserido no interior de uma casca cerâmica à base de zirconita para sustentação mecânica. Este conjunto era posicionado internamente a um susceptor de grafita, que era aquecido por uma bobina de indução ao seu redor e que aquecia o molde de quartzo em seu interior. Quartzo moído foi inserido no vão entre o tubo de quartzo e a casca de zirconita (Figuras 11 e 12) para facilitar a extração do tubo do interior da casca após o término do ensaio e para evitar a interação química entre os mesmos.

Quinze ensaios preliminares foram conduzidos para definição dos detalhes da montagem do molde utilizado nos quinze ensaios definitivos posteriores. Durante estes ensaios preliminares, foram alterados: a base dos tubos de quartzo; o tipo de revestimento interno ao tubo; o diâmetro e o comprimento dos tubos; a velocidade de extração do molde e a composição inicial do silício a ser refinado. No presente item serão mostrados apenas os detalhes da montagem do molde nestes ensaios preliminares, enquanto no item 4.4 outras condições destes ensaios serão apresentadas.

Em alguns ensaios preliminares, os tubos de quartzo foram revestidos internamente com BN para permitir a extração do lingote de Si dentro do tubo sem a ocorrência de fraturas. No entanto, o silício refinado nestes ensaios apresentou 
teores de B relativamente altos, resultantes da contaminação pelo revestimento. Logo, nos ensaios definitivos utilizou-se um revestimento de nitreto de silício $\left(\mathrm{Si}_{3} \mathrm{~N}_{4}\right)$, evitando a contaminação e a fratura dos lingotes.

Nos primeiros ensaios preliminares, a montagem com o tubo de quartzo foi apoiada sobre uma base de cobre extratora de calor refrigerada a água, como ilustrado na Figura 11(a) e (b). Entretanto, após análises químicas ao longo dos lingotes obtidos, notou-se que o silício junto à base solidificava logo após o vazamento (antes do início da extração), quando entrava em contato com a base refrigerada. O silício que solidificou causava o aparecimento de uma anomalia, denominada no presente trabalho de "transiente inicial", nos perfis de concentração dos elementos, dificultando a análise da transferência de massa segundo os modelos disponíveis na literatura. Os perfis de concentração obtidos nestes ensaios preliminares para alguns elementos estão mostrados no Capítulo 5.

Em uma tentativa de eliminar este transiente inicial, colocou-se um material isolante térmico entre o silício líquido e a base refrigerada, que não pôde ser removida por motivos operacionais do forno. Dois tipos de montagens foram testadas. A primeira, mostrada na Figura 11(c), foi composta por um bloco de alumina de aproximadamente $8 \mathrm{~cm}$ de altura (utilizado para separar o tubo de quartzo da base extratora de calor), discos de quartzo (para dificultar o transporte de calor entre o silício na base do tubo e a placa de cobre) e grafita para vedação da parte inferior do tubo de quartzo. Além disso, foram empregadas gavetas ou placas de separação entre as zonas quente e fria da câmara de solidificação para melhorar a isolação térmica entre as mesmas. As gavetas de separação consistem em duas placas à base de grafita dispostas horizontalmente (Figura 11(c)). Esta nova montagem eliminou o transiente inicial dos perfis de concentração, indicando que o silício estava completamente líquido no momento do início da extração do molde do interior da região quente do forno, como objetivado. 


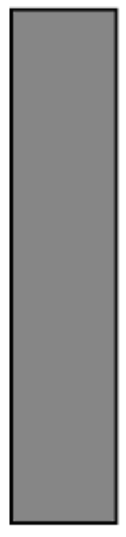

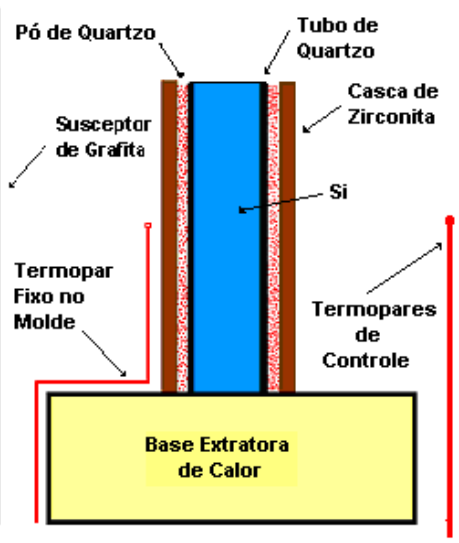

(a)

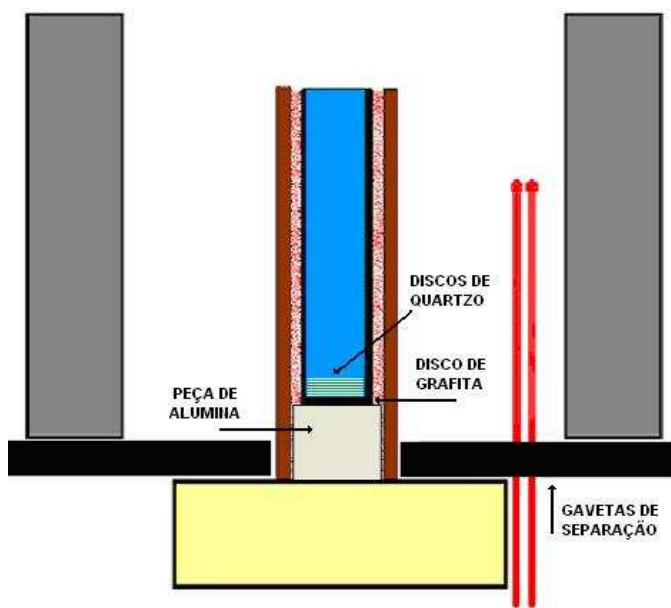

(c)
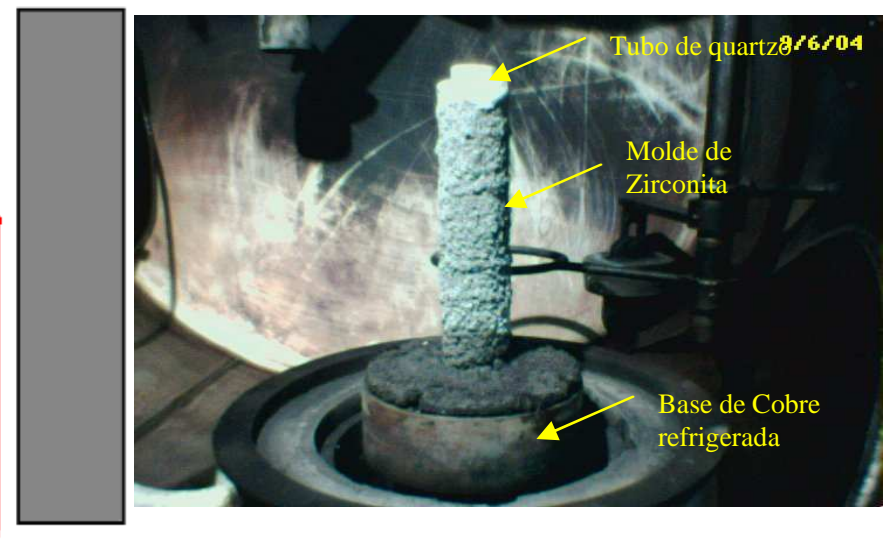

(b)

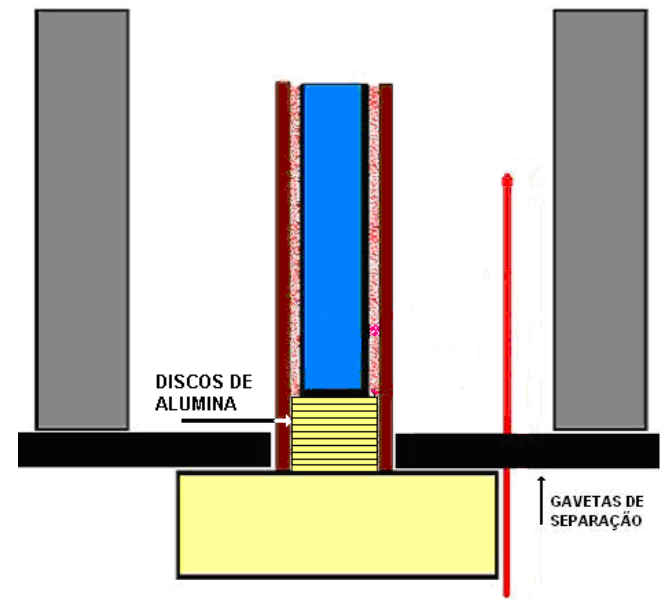

(d)

Figura 11 - Molde para solidificação direcional dos ensaios preliminares: (a) base de cobre refrigerada a água; (b) fotografia da montagem com a base de cobre refrigerada a água; (c) base formada por um bloco de alumina e discos de grafita e quartzo; (d) montagem experimental definitiva (tubo de quartzo grau solar fechado na extremidade inferior e separado da base de cobre por discos de alumina).

Apesar das montagens descritas no parágrafo anterior eliminarem 0 transiente inicial, houve vazamento do silício líquido através dos pequenos vãos existentes entre os discos e anéis isolantes e o tubo de quartzo. Logo, na montagem final foram utilizados tubos de quartzo de grau solar fechados na base, apoiados em onze discos de alumina com espessura média de 0,6 cm. Esta montagem, apresentada na Figura 11(d), foi utilizada em todos os ensaios definitivos.

A temperatura do forno de solidificação direcional foi controlada através de um ou dois termopares do tipo B (Pt-6\%Rh / Pt-30\%Rh) montados no vão entre o susceptor de grafita e a casca de zirconita (Figuras 11). Na realização dos ensaios 
definitivos, provavelmente por fragilização causada pela reação com residuos de $\mathrm{CO}$ existentes na atmosfera do forno (formados da reação entre residuais de $\mathrm{O}_{2}$ e o susceptor de grafita), estes termopares romperam-se freqüentemente, prejudicando os experimentos. Em uma tentativa de evitar o contato dos termopares com a atmosfera redutora do forno, os termopares foram encapsulados em um tubo de alumina fechado em sua extremidade. Entretanto, mesmo após esta nova montagem os termopares ainda se romperam em alguns ensaios.

Em um dos ensaios definitivos, foram introduzidos transversalmente dois termopares no interior do molde a distâncias de 10 e $15 \mathrm{~cm}$ em relação à base do tubo de quartzo (Figura 12). Esta montagem foi realizada em uma tentativa de medir o gradiente térmico no líquido junto à interface sólido-líquido. Cada um dos termopares foi introduzido no interior de pequenos tubos também de quartzo, que eram introduzidos transversalmente em dois furos feitos no molde de quartzo. No entanto, os termopares romperam-se antes do início da extração do molde, permitindo apenas a medida das temperaturas no silício líquido antes do início da extração do molde.

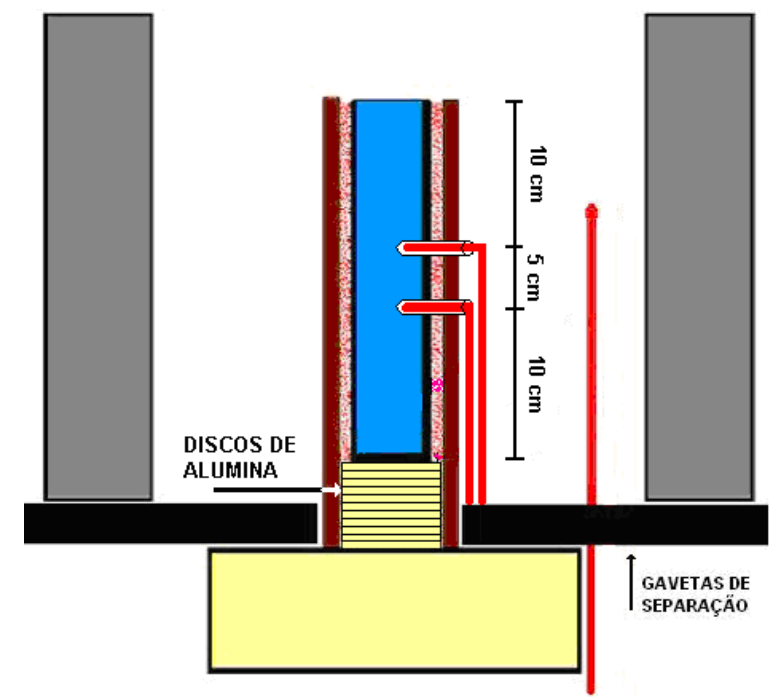

Figura 12 - Montagem experimental utilizada na tentativa de obtenção do gradiente térmico. 


\subsection{Materiais}

Os principais materiais utilizados nos ensaios de solidificação direcional foram o silício para o refino, os tubos de quartzo para a montagem do molde e os cadinhos de fusão. Dois tipos de silício foram introduzidos no forno para a realização dos ensaios de solidificação direcional: o silício de grau metalúrgico (SiGM), utilizado no estado como recebido da empresa produtora, e o silício previamente refinado (SiR), obtido após um pré-tratamento do SiGM. Este pré-tratamento consistiu de um refino pirometalúrgico com escórias sintéticas e injeção de oxigênio, e uma etapa posterior, constituída de dupla lixiviação ácida com duas etapas intercaladas de fusão e solidificação (não controlada) lenta para facilitar a segregação de impurezas e aumentar a eficiência da lixiviação.

A Tabela 7 apresenta as composições químicas do SiGM e SiR obtidas através da Espectroscopia de Emissão Atômica em Plasma Indutivamente Acoplado (ICP - AES, "Inductively Coupled Plasma Atomic Emission Spectroscopy"). O silício SiGM foi carregado no cadinho do forno de solidificação direcional com sua granulometria original (tamanho médio na faixa $10 \pm 1 \mathrm{~mm}$ ), enquanto que o $\mathrm{SiR}$ foi carregado com a granulometria proveniente do processo de lixiviação (tamanho médio na faixa de 20 a $500 \mu \mathrm{m})$.

Tabela 7 - Composição química (ppm em peso) das matérias primas empregadas na solidificação direcional

\begin{tabular}{|l|l|l|l|l|l|l|l|l|l|l|l|l|l|l|}
\cline { 2 - 8 } \multicolumn{1}{c|}{} & \multicolumn{10}{c|}{ Elemento (ppm peso) } \\
\hline $\begin{array}{l}\text { Matéria } \\
\text { Prima }\end{array}$ & Mn & $\mathbf{C r}$ & $\mathbf{N i}$ & $\mathbf{C a}$ & $\mathbf{A l}$ & $\mathbf{F e}$ & $\mathbf{T i}$ & $\mathbf{M g}$ & $\mathbf{N a}$ & $\mathbf{Z r}$ & $\mathbf{Z n}$ & $\mathbf{V}$ & $\mathbf{C u}$ & Total \\
\hline SiGM & 69 & 100 & 60 & 680 & 690 & 2800 & 140 & 11 & 10 & 17 & 2,4 & 5,7 & 240 & 4825 \\
\hline SiR & $<1,5$ & 2,5 & $<1,5$ & 2,2 & 8 & $18 \pm 2$ & $<8$ & 1,1 & $<1,5$ & 3 & $<1,0$ & $<1,5$ & $<8$ & $<57,6$ \\
\hline
\end{tabular}

Nos primeiros seis ensaios preliminares foram utilizados tubos de quartzo com $18 \mathrm{~cm}$ de altura, 2,4 cm de diâmetro interno e 3,0 cm de diâmetro externo. Nos ensaios preliminares restantes e nos ensaios definitivos utilizaram-se tubos de quartzo com $25 \mathrm{~cm}$ de altura, $3,4 \mathrm{~cm}$ de diâmetro interno e $4,0 \mathrm{~cm}$ de diâmetro externo. Dois tipos de cadinhos foram utilizados para a fusão do silício: na fusão do 
SiGM utilizou-se um cadinho de grafita de alta densidade com 18,0 cm de altura, 9,5 $\mathrm{cm}$ de diâmetro interno e 11,0 cm de diâmetro externo. Na fusão do SiR, um cadinho de quartzo grau solar (alto grau de pureza) com 18,0 cm de altura, 7,5 cm de diâmetro interno e $8,0 \mathrm{~cm}$ de diâmetro externo foi introduzido no interior do cadinho de grafita com o objetivo de evitar contaminação pelo contato com o mesmo.

\subsection{Condições dos Ensaios de Solidificação Direcional}

Trinta ensaios de solidificação direcional foram realizados, onde os primeiros quinze foram ensaios preliminares e os restantes, definitivos. No entanto, entre os quinze ensaios definitivos, apenas dez foram finalizados sem a ocorrência de algum tipo de problema operacional que impossibilitou a finalização do ensaio. Nos ensaios preliminares diversas tentativas foram realizadas alterando-se: o tipo de base dos tubos de quartzo (item 4.2); o tipo de revestimento interno ao tubo; o diâmetro e o comprimento dos tubos; a velocidade de extração do molde da zona quente para a zona fria e a composição inicial do silício a ser refinado. Estas condições estão indicadas na Tabela 8 para cada ensaio preliminar (EP). 
Tabela 8 - Condições dos ensaios preliminares de solidificação direcional, onde MP é a matéria prima utilizada; $m$ é massa de matéria prima; $V, t_{E}, L$ e $D$ são, respectivamente a velocidade de extração, o tempo total de extração, o comprimento e o diâmetro interno do molde; SiGM e SiR são, respectivamente, o silício grau metalúrgico e o silício previamente refinado e $\mathrm{BN}$ e $\mathrm{Si}_{3} \mathrm{~N}_{4}$ indicam a aplicação ou não do revestimento de nitreto de boro ou nitreto de silício, respectivamente, à superfície interna do tubo de quartzo.

\begin{tabular}{ccccccccc}
\hline Ensaio & $\mathbf{M P}$ & $\mathbf{m}(\mathbf{g})$ & $\mathbf{V}(\boldsymbol{\mu} \mathbf{m} / \mathbf{s})$ & $\mathbf{t}_{\mathbf{E}}(\mathbf{h})$ & $\mathbf{L}(\mathbf{m m})$ & $\mathbf{D}(\mathbf{m m})$ & Revest. & Montagem \\
\hline EP-01 & SiGM & 270 & 55 & 1 & 180 & 24 & Não & Figura 11a \\
EP-02 & SiGM & 270 & 10 & 6 & 180 & 24 & Não & Figura 11a \\
EP-03 & SiGM & 270 & 10 & 6 & 180 & 24 & Não & Figura 11a \\
EP-04 & SiR1 & 270 & 10 & 6 & 180 & 24 & Não & Figura 11a \\
EP-05 & SiGM & 270 & 55 & 1 & 180 & 24 & $\mathbf{B N}$ & Figura 11a \\
EP-06 & SiGM & 270 & 10 & 6 & 180 & 24 & $\mathbf{B N}$ & Figura 11a \\
EP-07 & SiGM & 540 & 10 & 6 & 250 & 34 & $\mathbf{B N}$ & Figura 11a \\
EP-08 & SiR2 & 540 & 5 & 12 & 250 & 34 & $\mathbf{B N}$ & Figura 11a \\
EP-09 & SiGM & 540 & 110 & 0,5 & 250 & 34 & $\mathbf{B N}$ & Figura 11a \\
EP-10 & SiGM & 540 & 5 & 12 & 250 & 34 & $\mathbf{B N}_{1}$ & Figura 11a \\
EP-11 & SiR2 & 540 & 5 & 12 & 250 & 34 & $\mathbf{S i}_{3} \mathbf{N}_{\mathbf{4}}$ & Figura 11a \\
EP-12 & SiGM & 540 & 5 & 12 & 250 & 34 & $\mathbf{S i}_{3} \mathbf{N}_{\mathbf{4}}$ & Figura 11c \\
EP-13 & SiGM & 540 & 5 & 12 & 250 & 34 & $\mathbf{S i}_{3} \mathbf{N}_{\mathbf{4}}$ & Figura 11c \\
EP-14 & SiGM & 540 & 5 & 12 & 250 & 34 & $\mathbf{S i}_{3} \mathbf{N}_{\mathbf{4}}$ & Figura 11c \\
EP-15 & SiGM & 540 & 5 & 12 & 250 & 34 & $\mathbf{S i}_{3} \mathbf{N}_{\mathbf{4}}$ & Figura 11c \\
\hline
\end{tabular}

As condições dos ensaios preliminares apresentadas na Tabela 8 foram estipuladas com diferentes objetivos. Nos ensaios EP-01, EP-02 e EP-03 examinouse o efeito da velocidade de extração, sendo que o EP-02 não foi concluído devido a um desligamento não programado do forno, causado por problemas elétricos. Nos ensaios EP-03 e EP-04 examinou-se o efeito da composição do silício utilizado como matéria prima. Os ensaios EP-05 e EP-06 foram realizados com o objetivo de examinar o efeito da aplicação do revestimento de BN à superfície interna do molde de quartzo. Estes testes mostraram que, com a aplicação do revestimento, o lingote poderia ser extraído sem fraturas. No entanto, observou-se uma contaminação de $B$ no lingote de silício solidificado direcionalmente, principalmente no ensaio mais longo (EP-06).

A partir do ensaio EP-07, o comprimento do tubo de quartzo foi aumentado de $180 \mathrm{~mm}$ para $250 \mathrm{~mm}$ e o seu diâmetro interno de $24 \mathrm{~mm}$ para $34 \mathrm{~mm}$. Esta modificação produziu lingotes mais compridos e mais grossos que os produzidos nos ensaios anteriores, facilitando a extração e preparação das amostras para as 
análises posteriores. Nestes ensaios, o efeito da velocidade de extração também foi examinado. O ensaio EP-11 foi conduzido para gerar um lingote refinado a ser analisado quimicamente pela técnica de espectrometria de massa por descarga luminosa (GDMS - "Glow Discharge Mass Spectrometry").

Nos ensaios EP-12 a EP-15 introduziu-se um suporte de alumina (Figura 11) em uma tentativa de eliminar o transiente inicial observado nos perfis de concentração dos lingotes refinados.

Os ensaios definitivos foram todos realizados nas mesmas condições experimentais, exceto pela velocidade de extração do molde e pela composição inicial do silício a ser refinado, que foram alterados de um ensaio para o outro. Nestes ensaios, utilizou-se um tubo de quartzo grau solar de $34 \mathrm{~mm}$ de diâmetro e $250 \mathrm{~mm}$ de comprimento, fechado em uma de suas extremidades. A superfície interna do tubo foi revestida com uma tinta à base de nitreto de silício, $\mathrm{Si}_{3} \mathrm{~N}_{4}$ que funcionou como lubrificante para facilitar a extração dos lingotes refinados do interior do molde. A massa de silício depositada no cadinho de fusão do forno foi de $540 \mathrm{~g}$. As demais condições estão apresentadas na Tabela 9.

Tabela 9 - Condições dos ensaios de solidificação direcional definitivos, onde MP é a matéria prima utilizada; SiGM e SiR são, respectivamente, o silício grau metalúrgico e o silício previamente refinado; $V$ e $t_{E}$ são, respectivamente, a velocidade de extração e o tempo total de extração. Os ensaios estão identificados com o prefixo GM e PR para matéria prima do tipo silício grau metalúrgico ou previamente refinado, respectivamente. O número após o prefixo indica a velocidade de extração na unidade de $\mu \mathrm{m} / \mathrm{s}$. Apenas os oito ensaios definitivos finalizados estão listados na tabela.

\begin{tabular}{lccc}
\hline Ensaio & MP & $\mathbf{V}(\boldsymbol{\mu m} / \mathbf{s})$ & $\mathbf{t}_{\mathrm{E}}(\mathbf{h})$ \\
\hline GM-05 & SiGM & 5 & 12 \\
GM-10 & SiGM & 10 & 6 \\
GM-20 & SiGM & 20 & 3 \\
GM-110 & SiGM & 110 & 0,5 \\
PR-5 & SiR & 5 & 12 \\
PR-10 & SiR & 10 & 6 \\
PR-20 & SiR & 20 & 3 \\
PR-110 & SiR & 110 & 0,5 \\
\hline
\end{tabular}




\subsection{Determinação da Morfologia da Interface Sólido/Líquido}

Durante o processo de solidificação direcional, quando a interface sólidolíquido é mantida plana, em determinadas condições as impurezas são segregadas para uma extremidade do lingote, obtendo-se uma purificação mais eficiente [GARCIA, 2001]. Quando a interface é dendrítica, observa-se um menor efeito de refino, pois grande parte das impurezas é segregada para a região entre os braços dendríticos em lugar de ser rejeitada para uma extremidade do lingote. Desta forma, a utilização de um gradiente de temperatura e velocidade de extração que mantenham a estabilidade da interface sólido-líquido plana é essencial para a eficiência do processo de refino.

O entendimento dos mecanismos de refino nos ensaios do presente trabalho depende em parte da identificação da morfologia da interface sólido-líquido, como discutido no parágrafo anterior. Um procedimento comum para identificar a existência de dendritas durante a solidificação é a observação dos vestígios desta estrutura na temperatura ambiente (após solidificação) em uma seção da amostra. Esta seção pode ser observada em microscópio óptico após polimento e ataque químico ou em microscópio eletrônico de varredura (em contraste de elétrons retroespalhados). Nos dois casos, pode-se obter um contraste de imagem causado pela microssegregação de elementos dissolvidos, resultantes da presença das dendritas durante a solidificação. Se esta segregação for pouco intensa ou porque o elemento não apresenta uma tendência significativa de segregar devido à baixa solubilidade das impurezas no sólido, a microssegregação é insuficiente para resultar em um contraste que revele as dendritas.

No caso das amostras de silício refinado obtidas no presente trabalho, não foi possível observar claramente a estrutura dendrítica devido à baixas concentrações de elementos. As imagens obtidas em microscópio óptico e eletrônico de varredura não mostraram claramente a microssegregação típica de uma estrutura dendrítica. Entretanto, em determinadas ligas, a microssegregação pode ocasionar o aparecimento de precipitados entre os braços de dendrita [GARCIA, 2001]. Logo, a presença de precipitados foi utilizada como um indicativo da existência da estrutura dendrítica. 
Além da observação da existência de precipitados nos lingotes refinados, uma outra estratégia foi adotada para se tentar identificar a morfologia da interface sólidolíquido. Esta estratégia foi aplicada a um ensaio conduzido nas mesmas condições do ensaio GM-05 (Tabela 9). Neste ensaio, durante a preparação da carga, adicionou-se 3\% de germânio para intensificar a microssegregação que se formaria caso a interface fosse dendrítica. Desta forma, seria possível observar a existência de braços de dendrita nas amostras examinadas em microscópio eletrônico de varredura.

Uma confirmação de que a estrutura dendrítica, caso existisse, seria revelada com a adição de 3\% de Ge ao SiGM foi obtida em um outro ensaio. O germânio foi escolhido por ser completamente solúvel no silício na fase sólida. Neste ensaio, uma carga de SiGM contendo 3\% de Ge foi inicialmente fundida em um forno a indução e, posteriormente, amostras líquidas foram retiradas através de um tubo de quartzo de $0,8 \mathrm{~cm}$ de diâmetro e $5,0 \mathrm{~cm}$ de comprimento. A liga líquida solidificou naturalmente neste tubo, sem qualquer controle de velocidade de solidificação ou temperatura. A estrutura bruta de solidificação resultante foi observada no microscópio eletrônico de varredura, mostrando uma estrutura dendrítica típica, apresentada na Figura 13

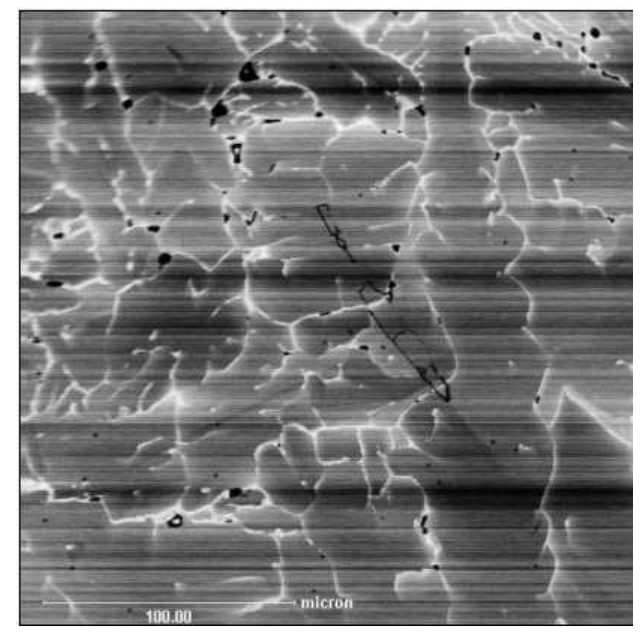

Figura 13 - Microscopia Eletrônica de Varredura do SiGM com 3\%Ge solidificado sem controle.

\subsection{Preparação das Amostras para Caracterização}

Após a finalização do processo de solidificação direcional, amostras foram retiradas dos lingotes de Si refinado e caracterizadas quanto à composição química 
e quanto à macro e microestrutura bruta de solidificação. O lingote foi inicialmente subdividido em dez partes, como mostra a Figura 14, e cada parte foi seccionada longitudinalmente, resultando em duas amostras com faces paralelas à direção de crescimento. A face de uma amostra foi preparada por técnicas metalográficas para revelar a micro e a macroestrutura, enquanto a outra amostra foi submetida à análise química.

\begin{tabular}{|c|c|c|c|c|c|c|c|c|c|}
\hline $\begin{array}{c}1 \\
\text { Base }\end{array}$ & 2 & 3 & 4 & 5 & 6 & 7 & 8 & 9 & $\begin{array}{c}10 \\
\text { Topo }\end{array}$ \\
\hline
\end{tabular}

Figura 14 - Esquema ilustrativo de um lingote cilíndrico de silício subdividido em várias amostras para posterior análise química e estrutural.

\subsection{Caracterização Micro e Macroestrutural}

As amostras destinadas à análise micro/macroestrutural foram preparadas por técnicas metalográficas convencionais. Realizaram-se sete etapas de lixamento com lixas d`água de 100, 180, 220, 320, 400, 600 e 1200 mesh. Em seguida as amostras foram polidas em três etapas com pasta de diamante de 6, 3 e 1 mícron. $O$ polimento final foi realizado com micro-sílica (sílica coloidal), a qual permite revelar a presença de possíveis intermetálicos precipitados, que são importantes para auxiliar na identificação da morfologia da interface sólido líquido (item 4.5).

As microestruturas das amostras preparadas foram observadas em microscópio óptico e eletrônico de varredura sem ataque químico. No entanto, as macroestruturas foram reveladas através do contato, durante 10 segundos, com um ataque químico composto de uma solução concentrada (1:1 em massa) de Hidróxido de Sódio a $90^{\circ} \mathrm{C}$. 


\subsection{Caracterização Química - Método Analítico}

\subsubsection{Caracterização Química por ICP}

Amostras foram retiradas do lingote de Si refinado (segundo o procedimento descrito no item 4.6) para análise química dos teores de $\mathrm{Fe}, \mathrm{Ca}, \mathrm{Al}, \mathrm{Ti}, \mathrm{V}, \mathrm{P}, \mathrm{Mn}, \mathrm{Cr}$, $\mathrm{Ni}, \mathrm{Zr}$, Zn, Cu e B. Três gramas de cada amostra foram dissolvidos sem moagem prévia (para evitar contaminação) em uma solução composta por $5 \mathrm{ml}$ de $\mathrm{HCl}$ e 15 ml de HF, ambos concentrados (PA). Após dissolução, adicionava-se água destilada e deionizada até um volume final de $100 \mathrm{ml}$. Em seguida, a solução final era levada ao equipamento de análise por espectroscopia de emissão atômica por plasma de argônio induzido, técnica analítica conhecida como ICP-AES ("Atomic Emission Spectroscopy Inductively Coupled Plasma"), ou simplesmente ICP, disponível nos laboratórios do Instituto de Pesquisas Tecnológicas (IPT).

Nesta técnica (ICP), que está disponível comercialmente desde 1970, a fonte de excitação para os espectrômetros de emissão baseia-se na ionização do argônio através de um campo magnético (plasma induzido) que sustenta a chama em temperaturas elevadas (parte fria a $T \cong 6000 \mathrm{~K}$ e parte quente a $\mathrm{T} \cong 10000 \mathrm{~K}$ ). Esta fonte de excitação confere diversas vantagens ao ICP em relação a outras técnicas como as de absorção atômica, que utilizam fontes de excitação convencionais (chama). Entre as vantagens, pode-se citar: limites de detecção em teores na ordem de ppb; menor efeito da matriz; e faixa dinâmica de trabalho (faixa linear) ampliada. A curva de calibração da técnica ICP pode ser obtida para uma faixa relativamente larga, como de 1 ppm a $10^{4}$ ppm, e sua estabilidade mantida por dias.

A curva de calibração para o ICP usado foi obtida diluindo-se uma solução padrão em quatro outras soluções de concentrações diferentes e conhecidas. Essas soluções eram lidas no aparelho e, com os respectivos valores, uma curva de calibração era levantada.

O limite de detecção em teores reduzidos é o maior atrativo da técnica ICP para o presente projeto, pois os teores de impurezas a serem analisados no silício refinado serão extremamente baixos e não poderiam ser analisados por técnicas convencionais. A técnica ICP indica um limite de detecção [Shimadzu - Catálogo] de 
1 ppb para Fe, Al, Ca, B e Ti, e de 1 a 10 ppb para o P. Maiores detalhes da técnica ICP-AE podem ser obtidos na literatura [MURRAY e LOGRASSO, 1990; FAIRES, 1988].

Embora o ICP possua limites de detecção da ordem de 1 a 10 ppb, estes limites não foram reproduzidos nas análises realizadas neste trabalho, onde foram obtidos limites da ordem de 3 a 17 ppm. Postula-se que os limites de detecção maiores em comparação aos especificados no catálogo do equipamento foram ocasionados por algum tipo de contaminação durante a preparação das amostras. A preparação envolveu a dissolução em água deionizada, a dissolução em ácidos (que possuem um determinado nível de impurezas), o contato com vidrarias e a utilização de capelas onde análises de outros tipos de ligas eram também realizadas. Além disso, o equipamento de ICP empregado no presente trabalho é rotineiramente utilizado para analisar outras ligas, podendo resultar em algum tipo de interferência.

O limite de detecção do ICP utilizado no presente trabalho foi obtido da seguinte forma: a partir de uma solução padrão eram obtidas outras soluções de concentração conhecida (variando entre 20 ppm e 1 ppm). Estas soluções eram submetidas à leitura pelo ICP seguindo a ordem decrescente de concentração (da mais concentrada para a menos concentrada). A concentração mais baixa a ser lida com precisão pelo aparelho seria tomada como o limite de detecção para aquele determinado elemento.

Algumas análises foram realizadas também por espectrometria de massa por plasma indutivamente acoplado (ICP-MS - "Inductively coupled plasma mass spectrometry"), disponível no Laboratório de Análises do Departamento de Geociências da USP para confirmar os resultados obtidos no equipamento de ICP AES localizado no IPT. Observou-se uma grande consistência entre os dois tipos de resultados.

\subsubsection{Caracterização Química por GDMS}

Algumas amostras extraídas para análises químicas dos lingotes obtidos nos ensaios GM-5, GM-10, PR-5, PR-10, PR-20 e PR-110 foram analisadas através da técnica de espectrometria de massa por descarga luminosa (GDMS - "Glow 
Discharge Mass Spectrometry"). Esta técnica não está disponível no Brasil, portanto as amostras foram enviadas para análise no Northern Analytical Laboratory localizado em New Hampshire, nos Estados Unidos.

Uma pequena amostra sólida foi retirada de cada fatia de silício e submetida à leitura pelo GDMS. As Figuras 15 e 16 mostram a geometria da amostra levada à análise.

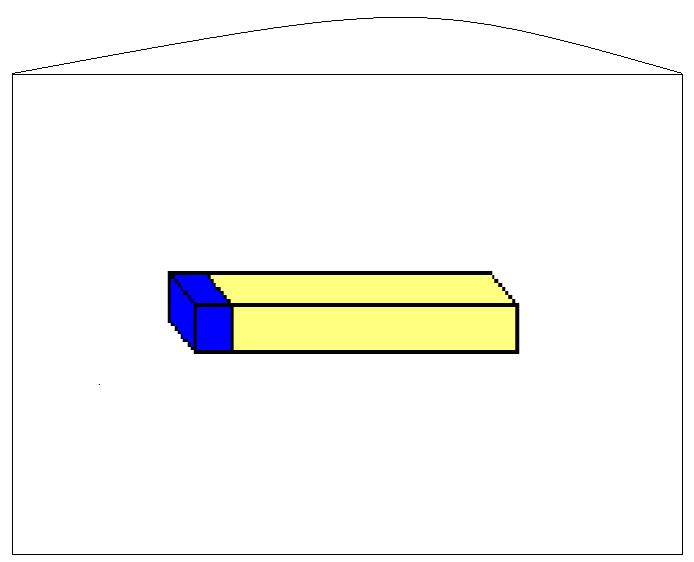

Figura 15 - Fatia de Si com a região a ser retirada para análise por GDMS demarcada

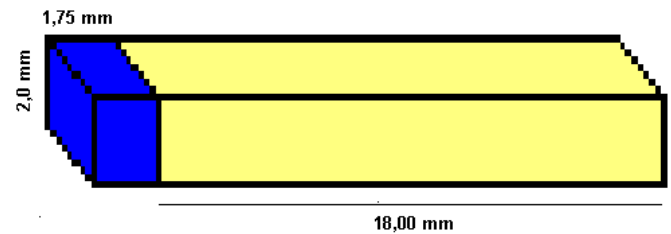

Figura 16 - Representação da amostra levada ao GDMS

A região em azul foi a área utilizada para realização da varredura. A área restante (na cor amarela) é utilizada para fixação (encaixe) da amostra no suporte de leitura.

O GDMS é uma técnica analítica tão sensível quanto o ICP, apresentando limites de detecção da ordem de 1 ppb [INOUE e SAKA, 1999]. O seu funcionamento envolve a atomização de uma amostra sólida (sem cominuição prévia), onde os átomos do material a ser analisado são espalhados em um plasma de corrente contínua de baixa pressão. Estes átomos são então ionizados no plasma e extraídos para o analisador mássico por separação e detecção. O plasma usado para análise está contido em uma célula de descarga feita de Tântalo puro. Para a maioria das aplicações, argônio ultrapuro é utilizado, embora gases como $\mathrm{He}, \mathrm{Ne} e$ Kr sejam utilizados em aplicações específicas. A pressão no interior da célula é de 1 torr. Um potencial de $1-2 \mathrm{kV}$ é aplicado entre o ânodo (corpo da célula) e o catodo (amostra) de modo a estabelecer a descarga de chama, com uma corrente entre 0,5 e 5 mA [BOGAERTS e GIJBELS, 1999, WAGATSUMA et al, 2002]. 
Íons positivos formados no interior da chama são acelerados em direção à amostra. Sob 0 impacto na superfície da amostra, partículas neutras (predominantemente átomos individuais) e íons positivos são liberados. Os íons positivos formados são atraídos novamente para a superfície da amostra e redepositados. As partículas neutras formadas difundem-se através do plasma rodeando o catodo em direção à região do ânodo do plasma, sendo subseqüentemente ionizado através da interação com os íons de argônio. Esses íons são acelerados em direção ao analisador mássico onde são analisados [BOGAERTS e GIJBELS, 1999].

\subsubsection{Caracterização Química por Microssonda EDS}

As amostras do topo dos ensaios GM-05 e PR-05 foram analisadas utilizando Espectrometria de Descarga de Energia (EDS - Energy Discharge Spectrometry) com o intuito de analisar a composição química específica dos intermetálicos contidos no topo desses lingotes. O aparelho utilizado para tanto foi um Microscópio Eletrônico de Varredura existente no Laboratório de Microscopia do Departamento de Engenharia de Minas e Petróleo da Escola Politécnica da USP. A preparação das amostras para esta analise foi a mesma descrita no item 4.7. 
CAPÍTULO 5

RESULTADOS 


\subsection{RESULTADOS}

A seguir serão apresentados os resultados obtidos através do processo de solidificação direcional aplicado ao refino do silício. Primeiramente serão mostradas as análises químicas na forma de perfis de concentração e tabelas contendo análises de $\mathrm{Fe}, \mathrm{Al}, \mathrm{Ca}, \mathrm{Cu}, \mathrm{Ti}, \mathrm{V}, \mathrm{Zn}, \mathrm{Zr}, \mathrm{Mn}, \mathrm{Cr}, \mathrm{Ni}, \mathrm{B}$ e $\mathrm{P}$ ao longo dos lingotes refinados. Posteriormente, serão apresentadas as micro e macrografias observadas nos microscópios óptico e eletrônico de varredura. Finalmente, o perfil térmico obtido para a estimativa do gradiente de temperatura será mostrado.

A Figura 17 exibe um lingote de silício típico obtido através do processo de solidificação direcional empregado no presente trabalho. Este lingote possui $250 \mathrm{~mm}$ de comprimento e $34 \mathrm{~mm}$ de diâmetro. A região à esquerda consiste na base do lingote, região que foi a primeira a solidificar, e à direita encontra-se o topo do lingote, região que solidificou ao final do processo.

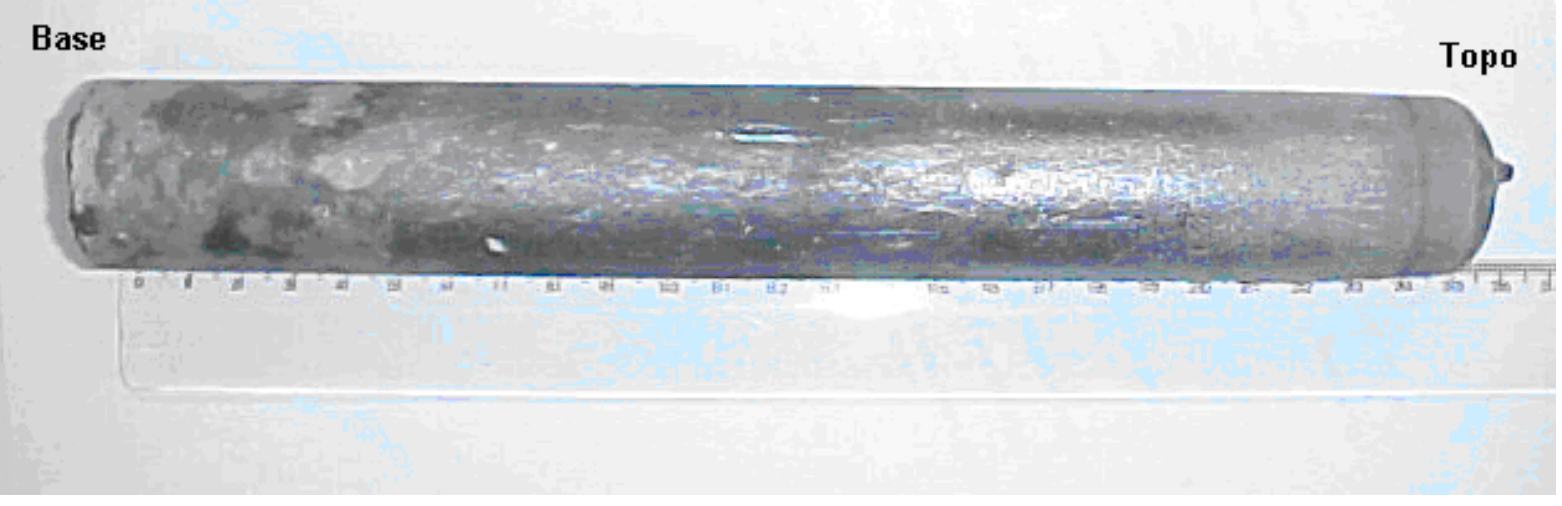

Figura 17 - Lingote de silício solidificado direcionalmente (comprimento: 250 mm, diâmetro: $34 \mathrm{~mm}$ ).

\subsection{Perfis de Concentração}

Os resultados deste subitem consistem das análises químicas realizadas por ICP e GDMS, organizadas na forma de perfis de concentração de diversos elementos ao longo dos lingotes refinados por solidificação direcional (Figuras 18 a 47). Serão apresentados perfis relativos aos ensaios definitivos, denominados GM05, GM-10, GM-20, GM-110, PR-05, PR-10, PR-20, PR-110 e descritos na Tabela 9 do item de metodologia experimental. Também será apresentado o perfil de 
somatório de impurezas para os ensaios preliminares EP-07, EP-09 e EP-10, descritos na Tabela 8 do mesmo item. No somatório de impurezas foram consideradas todas as impurezas analisadas pelo ICP-AES.

Nos gráficos que mostram os perfis, existem diversos pontos isolados, que não estão conectados por linhas. Estes pontos isolados representam as análises realizadas através do GDMS.

Nos perfis, a escala logarítmica no eixo das ordenadas foi utilizada com 0 objetivo de facilitar a comparação entre os diversos perfis de concentração. Nestes

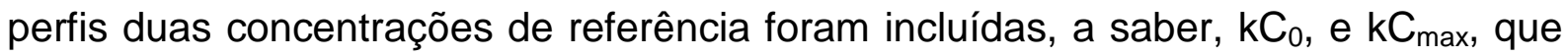
representam os limites mínimo e máximo da concentração do elemento no silício. $O$ limite de detecção (LD-ICP) do ICP também está indicado. Os pontos isolados (geralmente abaixo do LD-ICP), que não estão conectados por linhas, representam as análises por GDMS nas condições indicadas pelo símbolo equivalente da legenda. A concentração de referência mínima foi calculada por $\mathrm{kC}_{0}$, onde $\mathrm{k}$ é o coeficiente de partição de soluto obtido a partir da Tabela 5. A concentração de referência máxima foi calculada por $\mathrm{kC}_{\max }$, onde $\mathrm{C}_{\max }$ é a máxima concentração do elemento no Si líquido, observada no diagrama binário Si-elemento, na região rica em Si e na temperatura de final de solidificação, onde se observa uma transformação de ponto invariante (eutético ou peritético). Os valores de $\mathrm{C}_{\max }$ utilizados nos cálculos foram extraídos dos diagramas apresentados no Metals Handbook [American Society for Metals International. Handbook Committee] e estão também mostrados na Tabela 10.

Tabela 10 - Valores de $\mathrm{k}$ e $\mathrm{C}_{\text {máx }}$ para alguns elementos

\begin{tabular}{|ccc|}
\hline Metal & $\mathrm{k}$ & $\mathrm{C}_{\text {máx }}(\mathrm{ppm})$ \\
\hline $\mathrm{Al}$ & $210^{-3}$ & 1744 \\
$\mathrm{~B}$ & 0.8 & 25.600 \\
$\mathrm{Cr}$ & $10^{-5}$ & 2,9 \\
$\mathrm{Cu}$ & $410^{-4}$ & 64 \\
$\mathrm{Fe}$ & $810^{-6}$ & 3,3 \\
$\mathrm{Mn}$ & $10^{-5}$ & 5 \\
$\mathrm{Ni}$ & $10^{-4}$ & 63 \\
$\mathrm{Ti}$ & $10^{-5}$ & 2,5 \\
$\mathrm{~V}$ & $10^{-5}$ & 0,5 \\
$\mathrm{Zn}$ & $10^{-5}$ & 10 \\
$\mathrm{Zr}$ & $1,510^{-8}$ & 0,004 \\
\hline
\end{tabular}




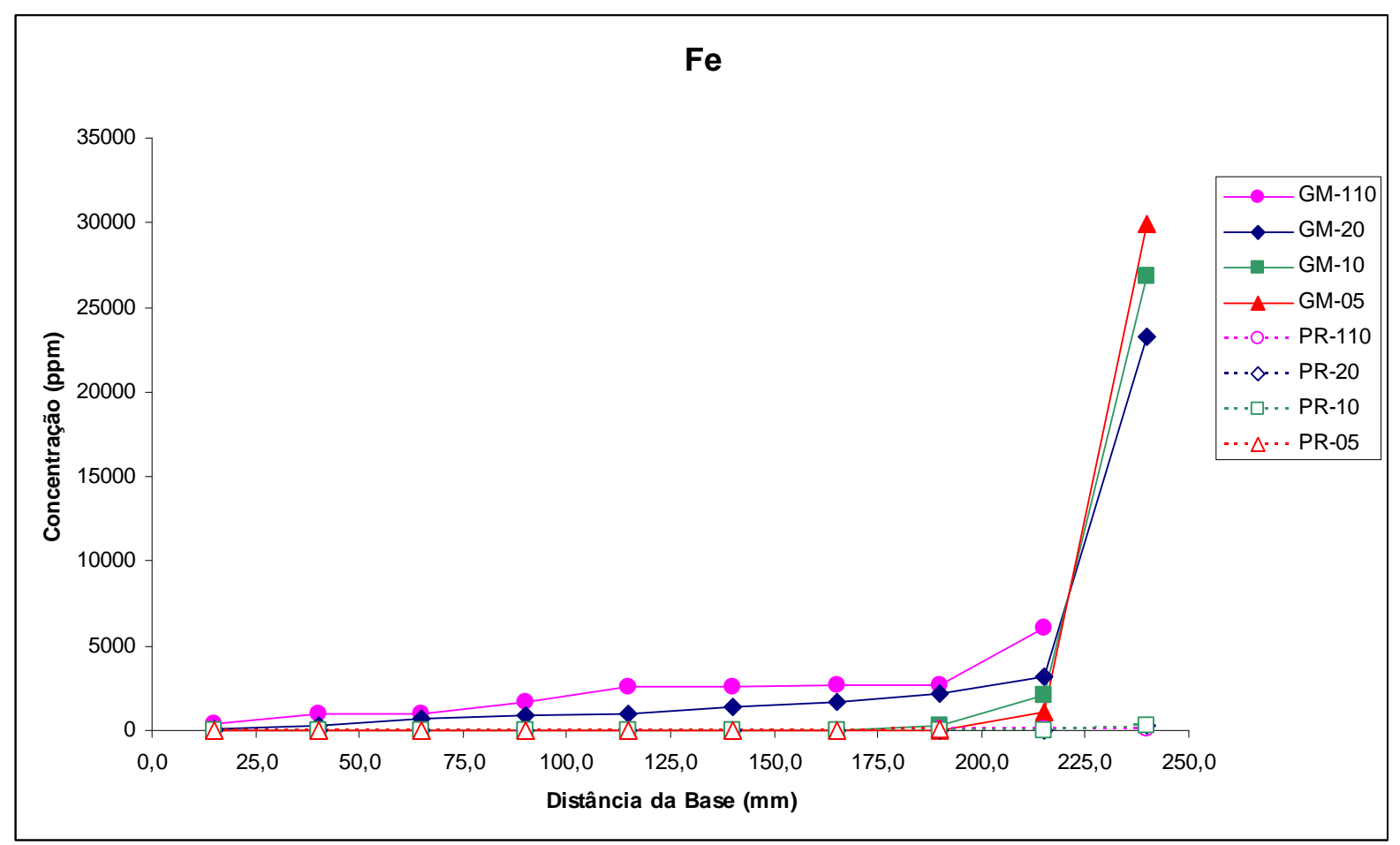

Figura 18a - Perfis de concentração do Fe ao longo dos lingotes obtidos por solidificação direcional do silício em diferentes concentrações iniciais e diferentes velocidades de extração do molde, segundo as condições definidas na Tabela 9.

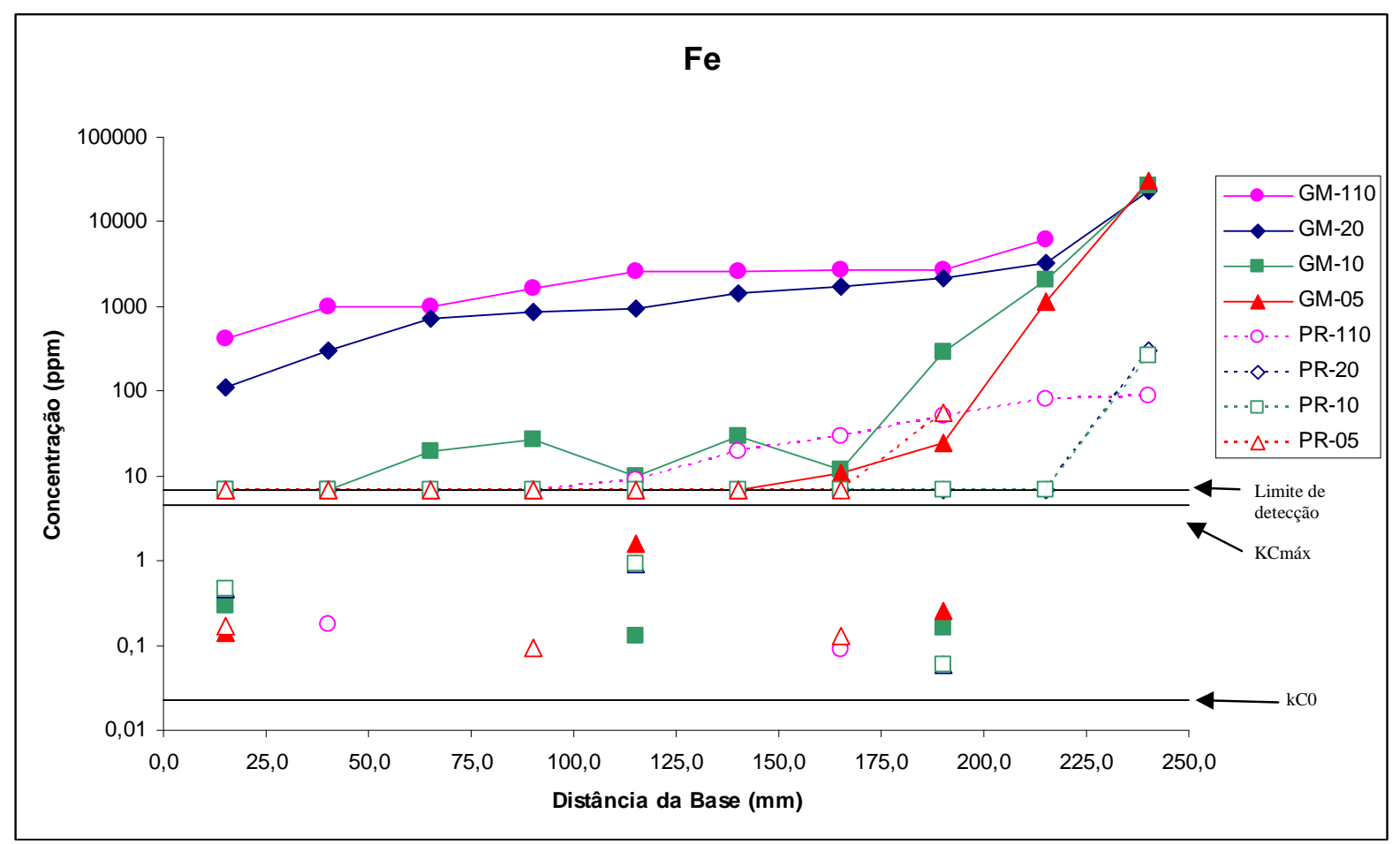

Figura 18b - Perfis de concentração do Fe (escala logarítmica) ao longo dos lingotes obtidos por solidificação direcional do silício em diferentes concentrações iniciais e diferentes velocidades de extração do molde, segundo as condições definidas na Tabela 9. 


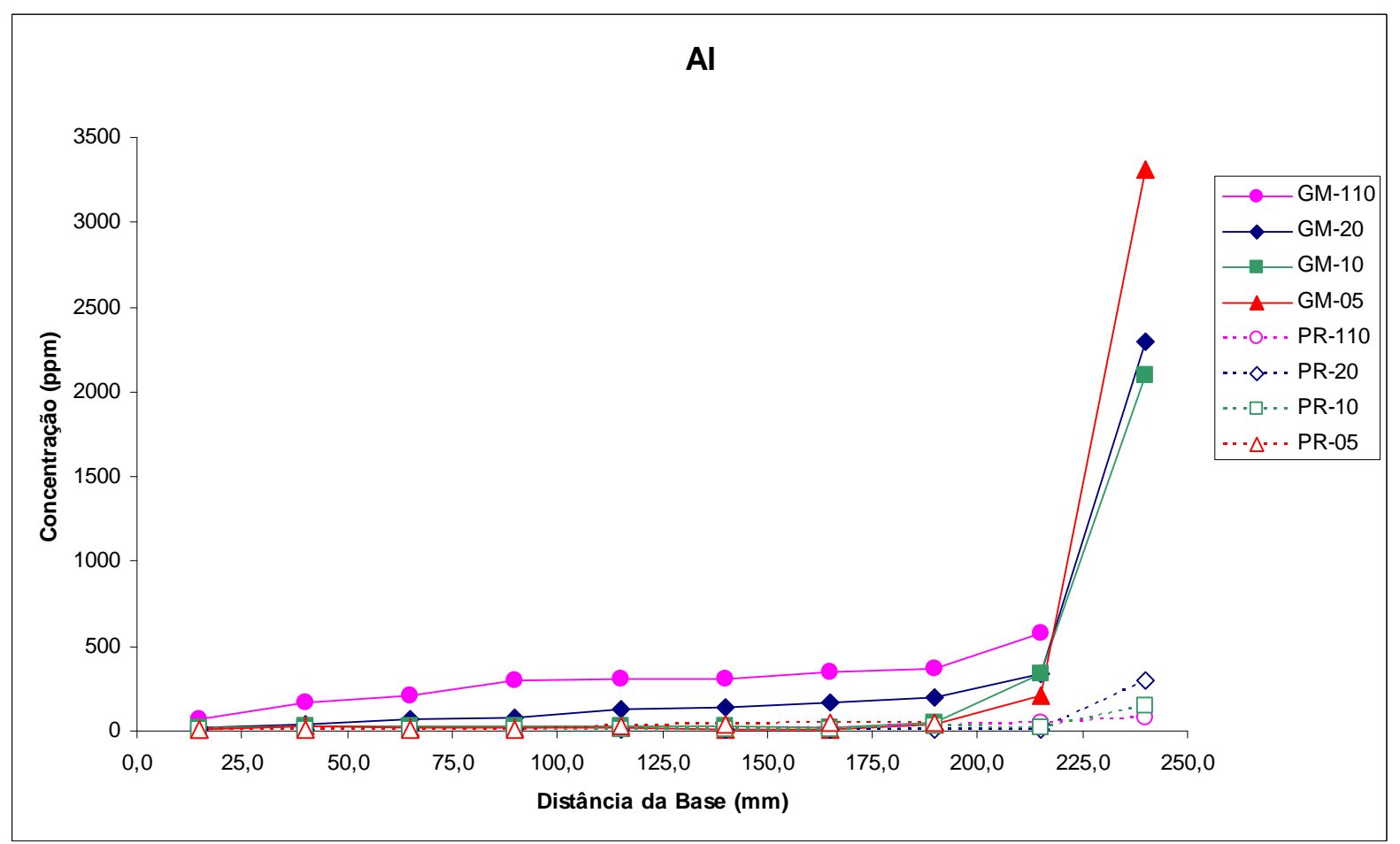

Figura 19a - Perfis de concentração do Al ao longo dos lingotes obtidos por solidificação direcional do silício em diferentes concentrações iniciais e diferentes velocidades de extração do molde, segundo as condições definidas na Tabela 9.

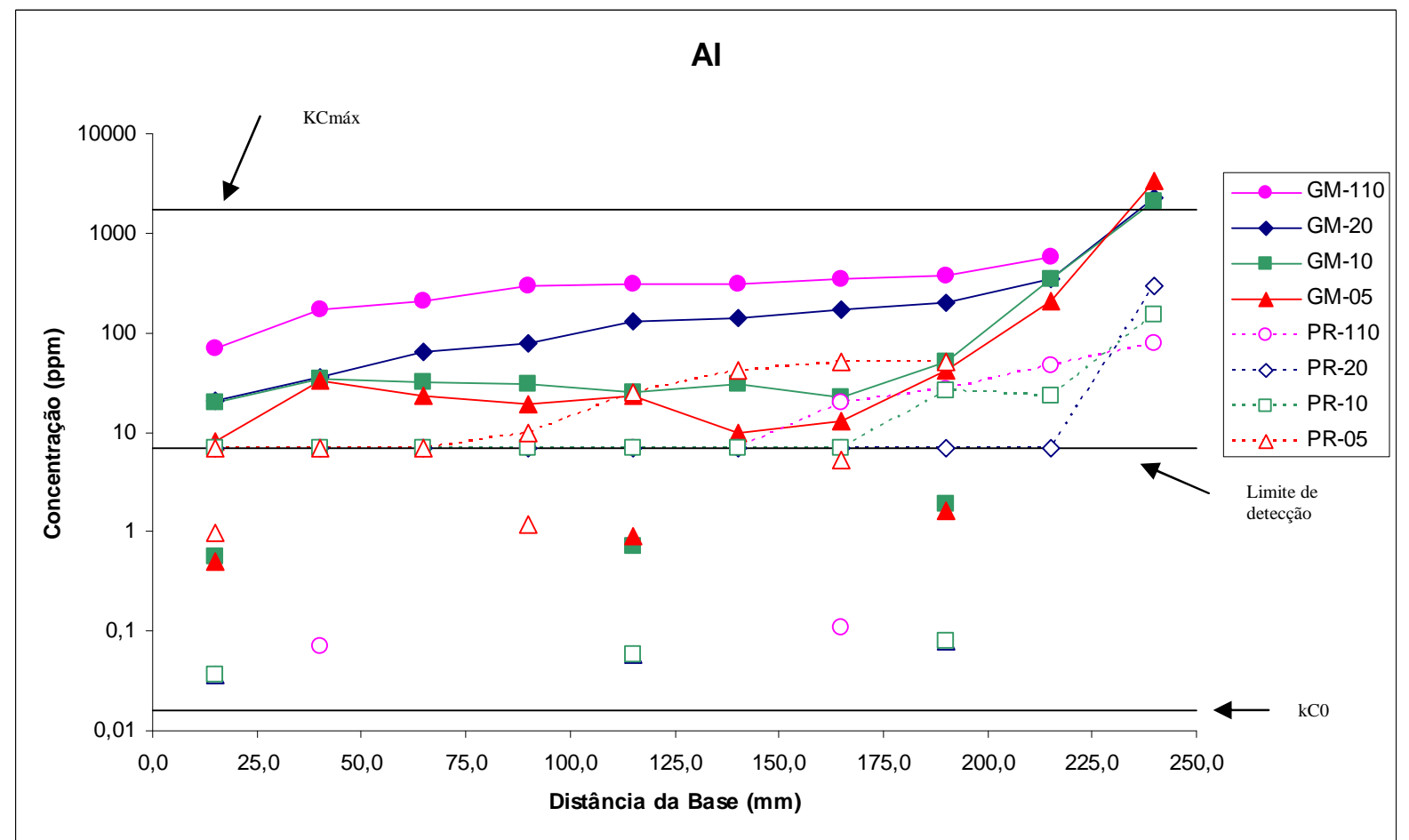

Figura 19b - Perfis de concentração do Al (escala logarítmica) ao longo dos lingotes obtidos por solidificação direcional do silício em diferentes concentrações iniciais e diferentes velocidades de extração do molde, segundo as condições definidas na Tabela 9. 


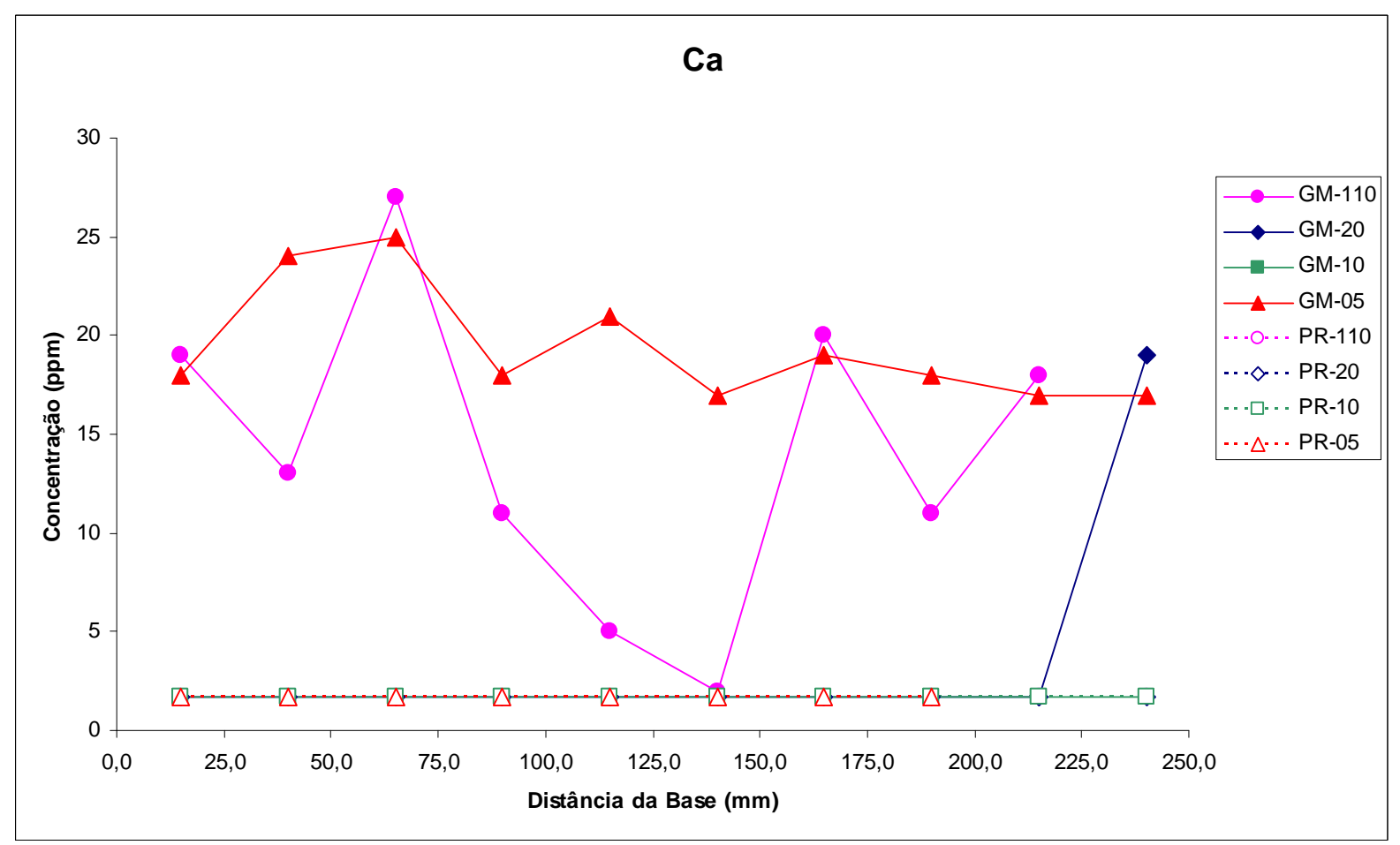

Figura 20a - Perfis de concentração do $\mathrm{Ca}$ ao longo dos lingotes obtidos por solidificação direcional do silício em diferentes concentrações iniciais e diferentes velocidades de extração do molde, segundo as condições definidas na Tabela 9.

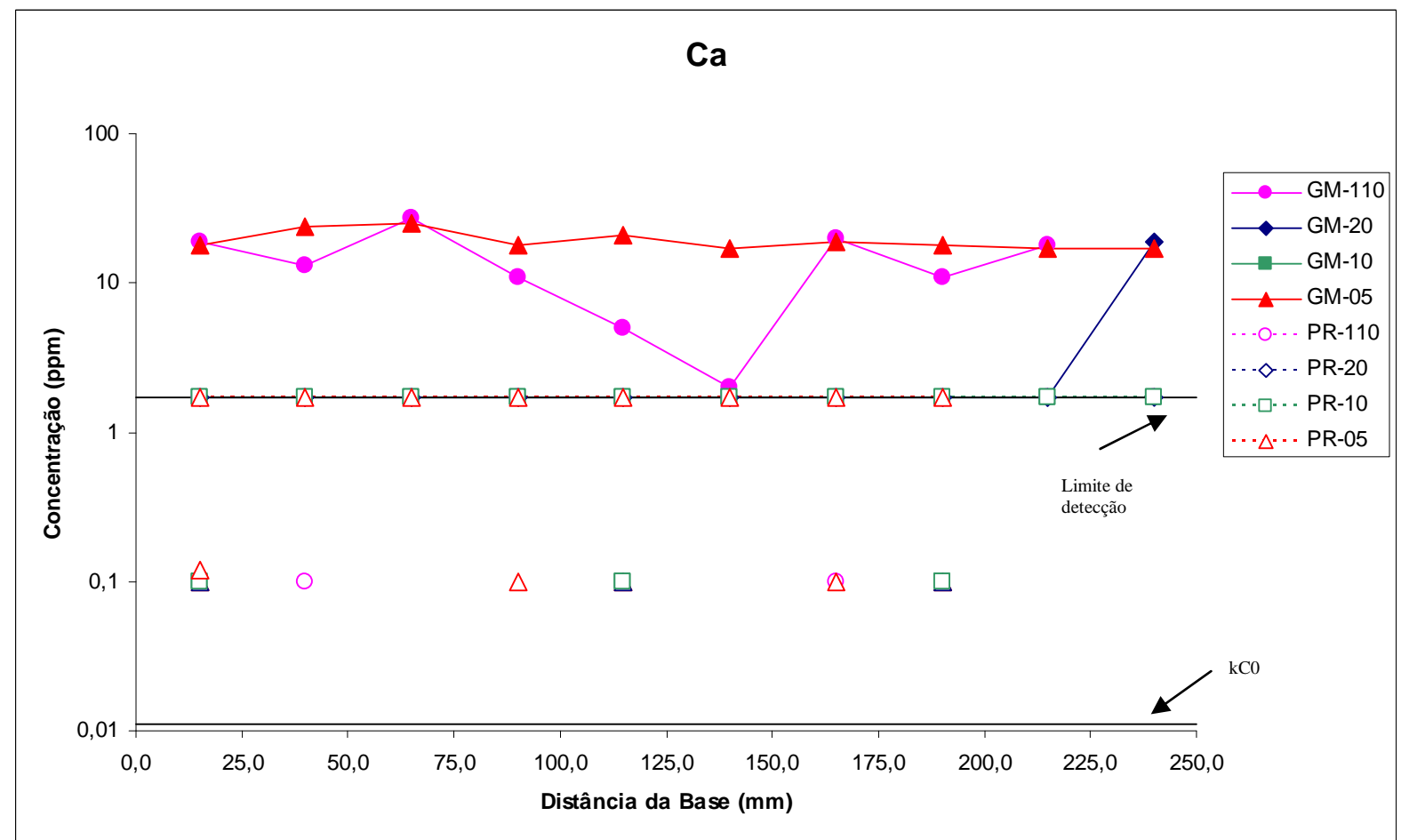

Figura 20b - Perfis de concentração do Ca (escala logarítmica) ao longo dos lingotes obtidos por solidificação direcional do silício em diferentes concentrações iniciais e diferentes velocidades de extração do molde, segundo as condições definidas na Tabela 9. 


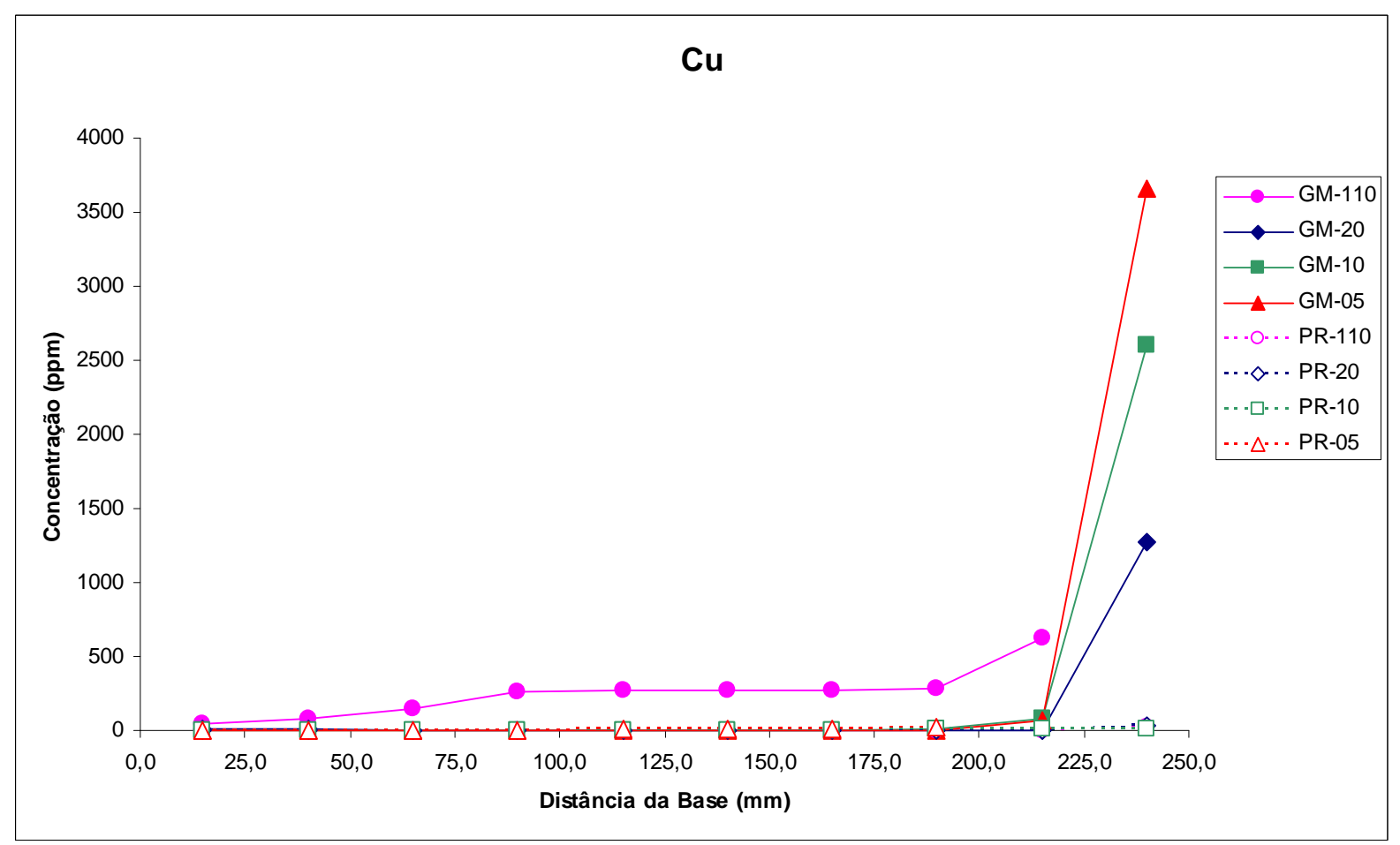

Figura 21a - Perfis de concentração do $\mathrm{Cu}$ ao longo dos lingotes obtidos por solidificação direcional do silício em diferentes concentrações iniciais e diferentes velocidades de extração do molde, segundo as condições definidas na Tabela 9.

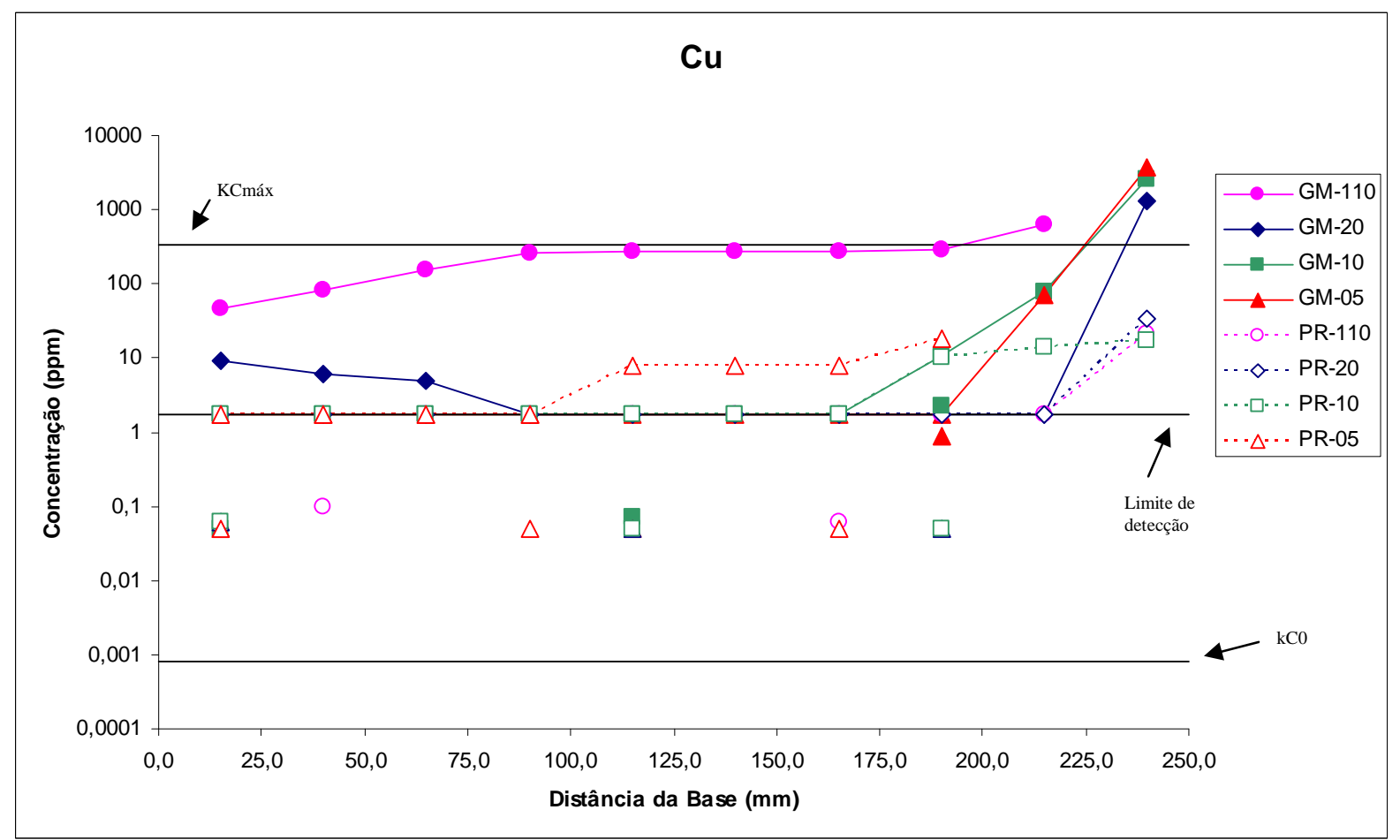

Figura 21b - Perfis de concentração do Cu (escala logarítmica) ao longo dos lingotes obtidos por solidificação direcional do silício em diferentes concentrações iniciais e diferentes velocidades de extração do molde, segundo as condições definidas na Tabela 9. 


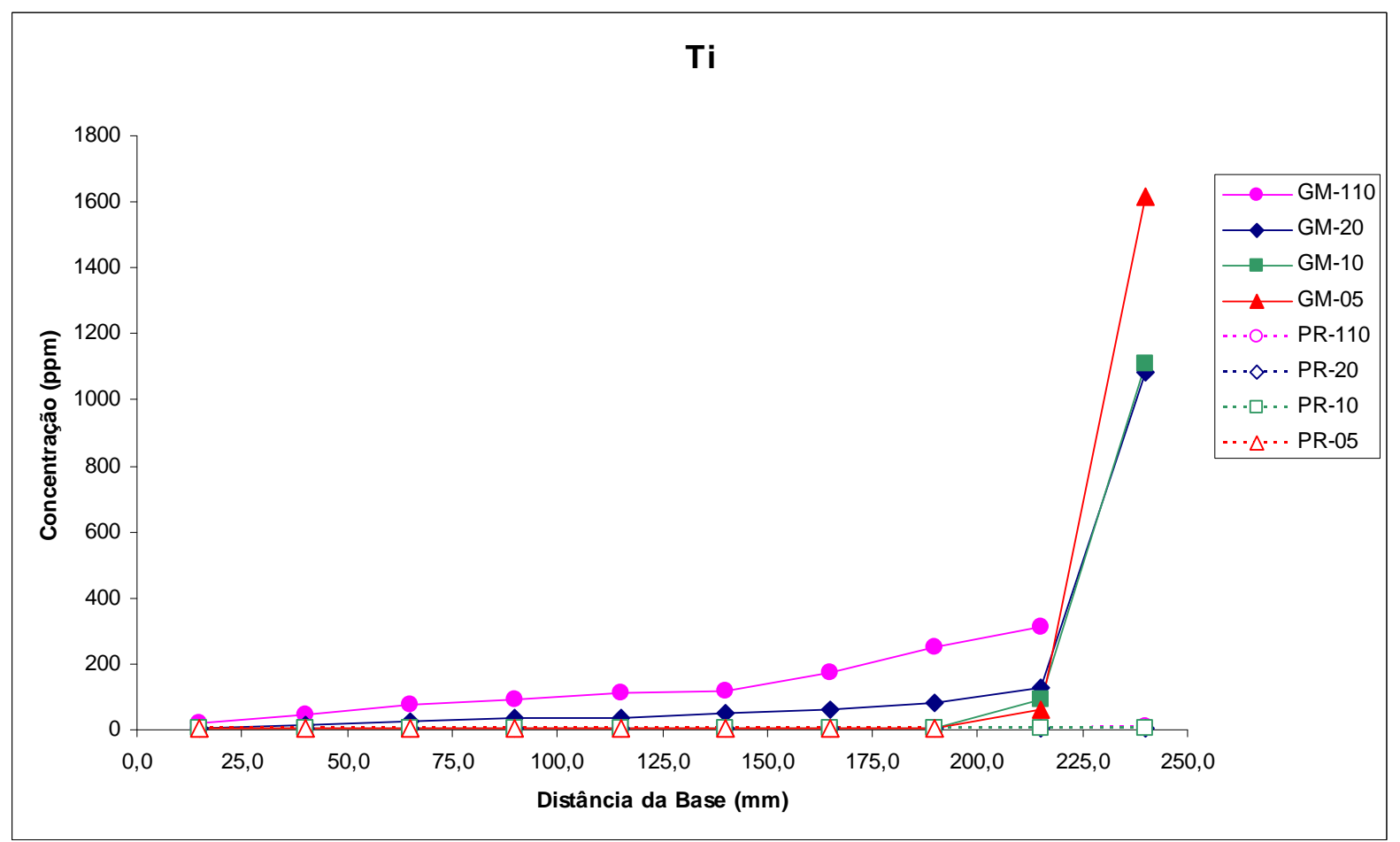

Figura 22a - Perfis de concentração do Ti ao longo dos lingotes obtidos por solidificação direcional do silício em diferentes concentrações iniciais e diferentes velocidades de extração do molde, segundo as condições definidas na Tabela 9.

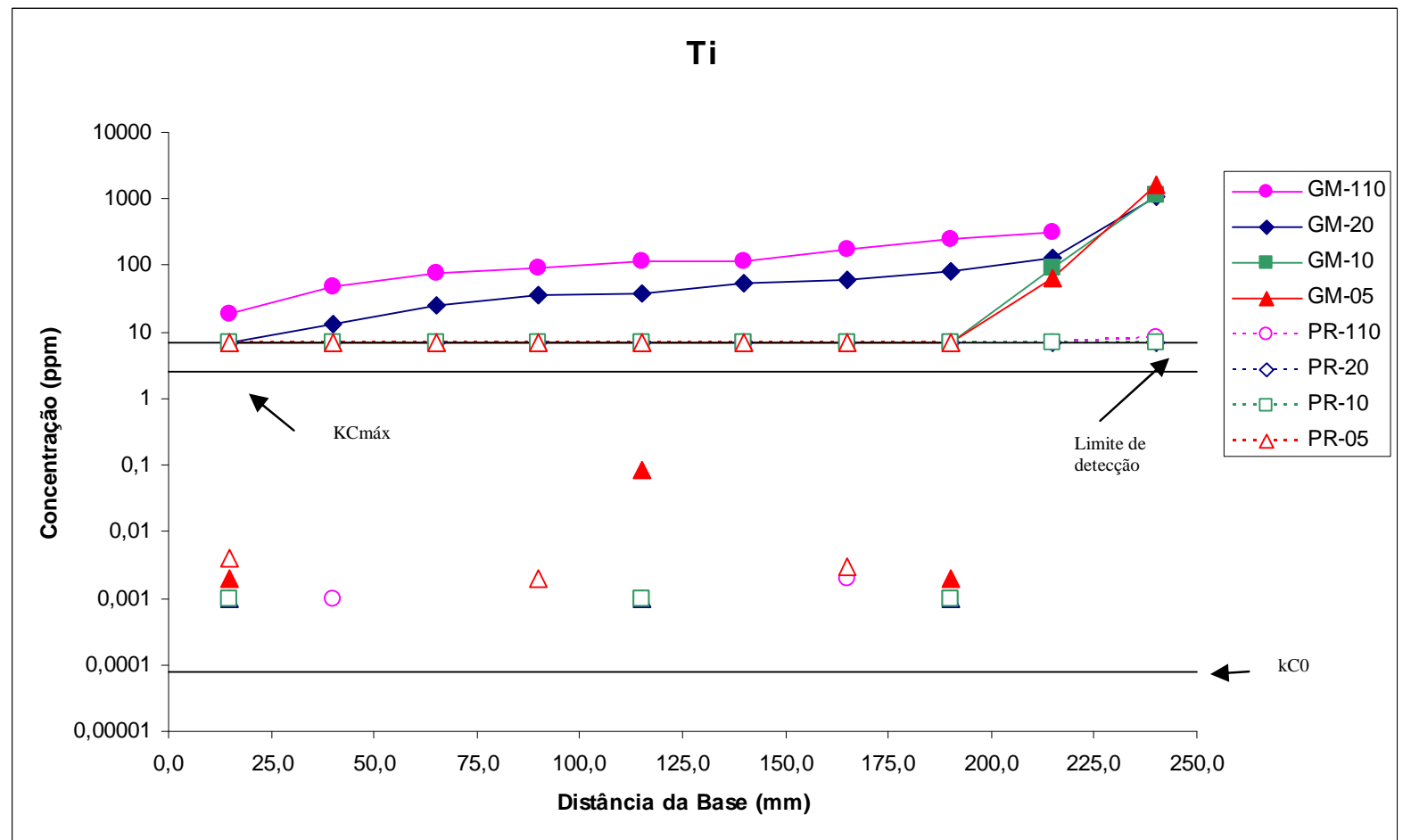

Figura 22b - Perfis de concentração do Ti (escala logarítmica) ao longo dos lingotes obtidos por solidificação direcional do silício em diferentes concentrações iniciais e diferentes velocidades de extração do molde, segundo as condições definidas na Tabela 9. 


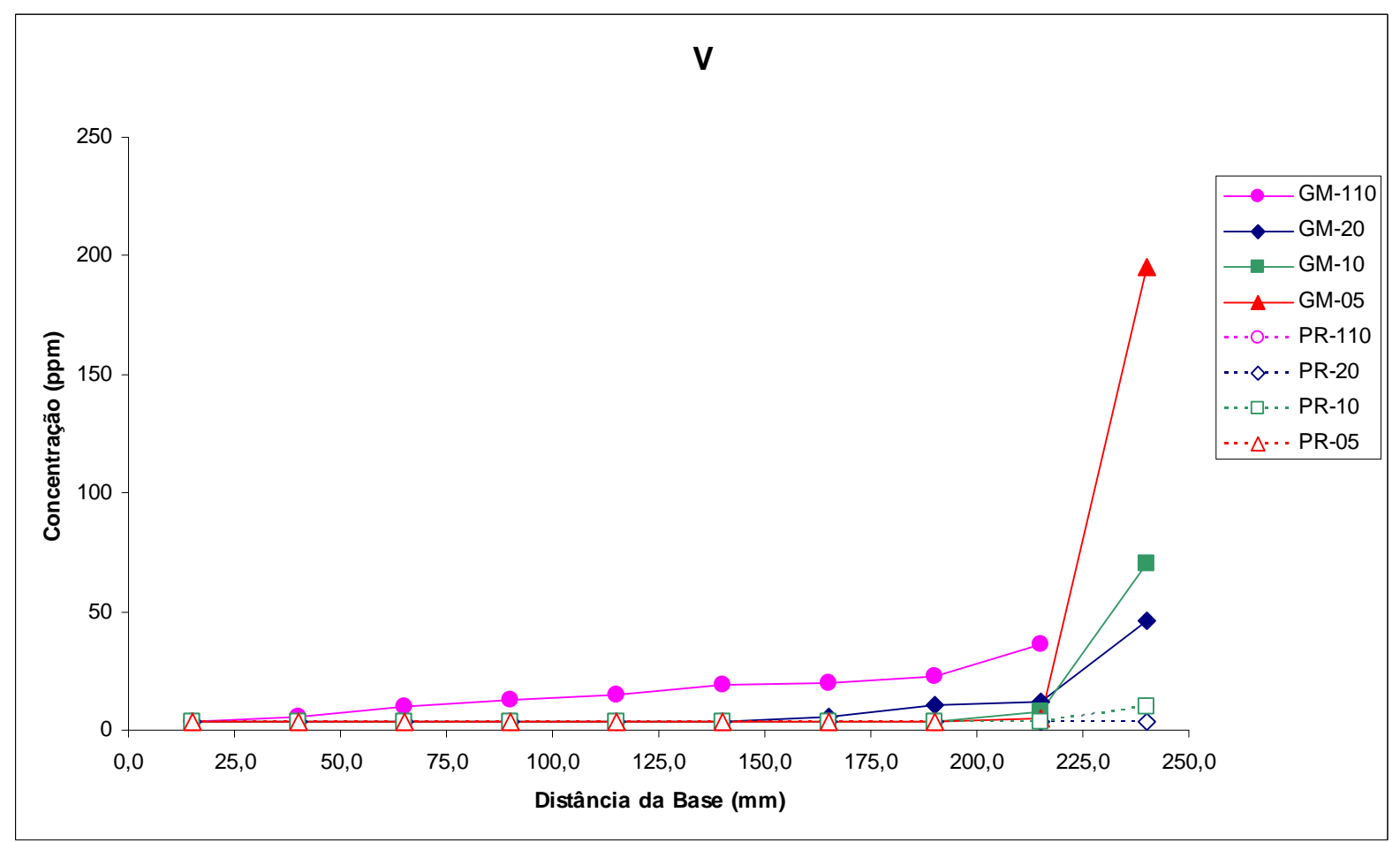

Figura 23a - Perfis de concentração do $V$ ao longo dos lingotes obtidos por solidificação direcional do silício em diferentes concentrações iniciais e diferentes velocidades de extração do molde, segundo as condições definidas na Tabela 9.

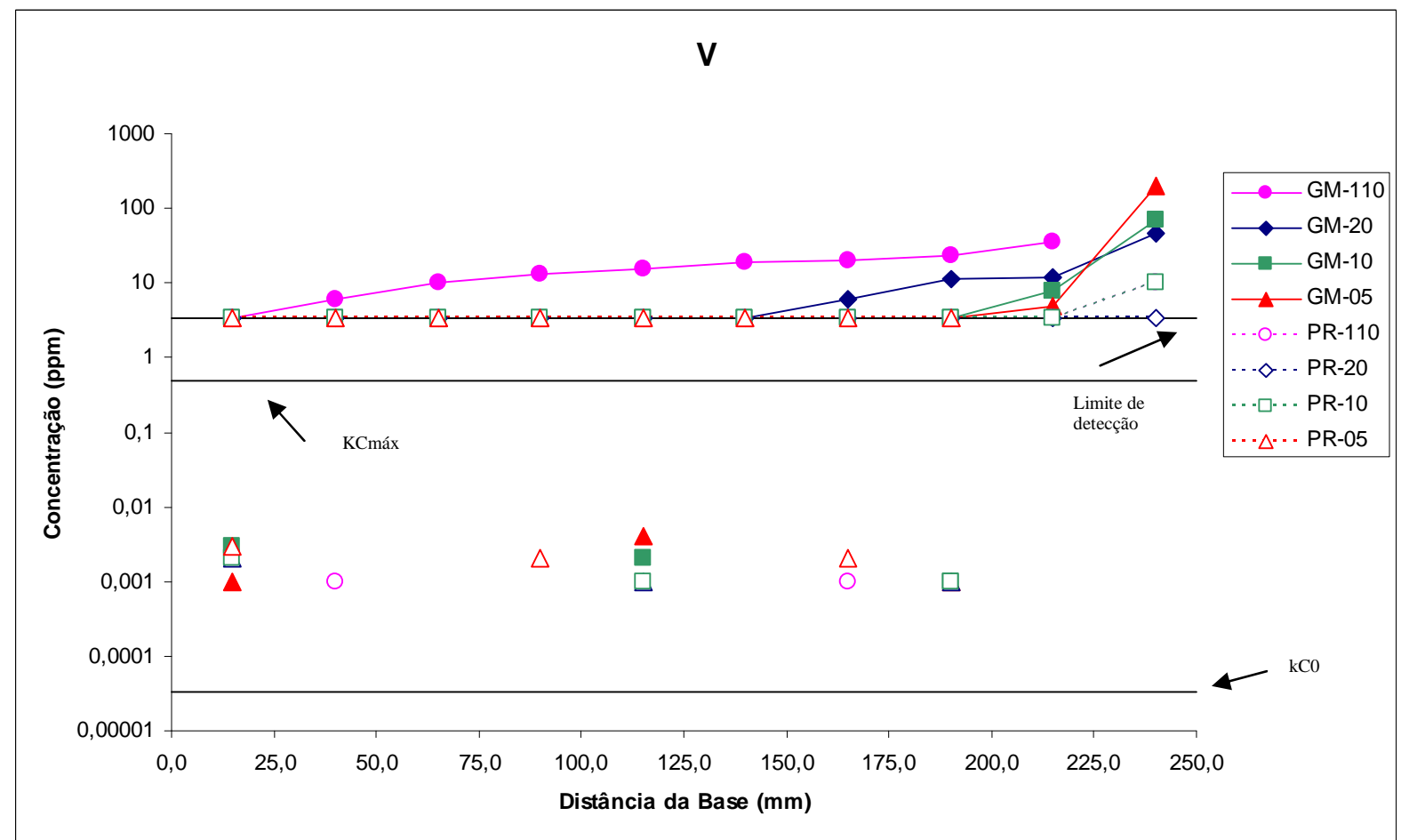

Figura 23b - Perfis de concentração do $\mathrm{V}$ (escala logarítmica) ao longo dos lingotes obtidos por solidificação direcional do silício em diferentes concentrações iniciais e diferentes velocidades de extração do molde, segundo as condições definidas na Tabela 9. 


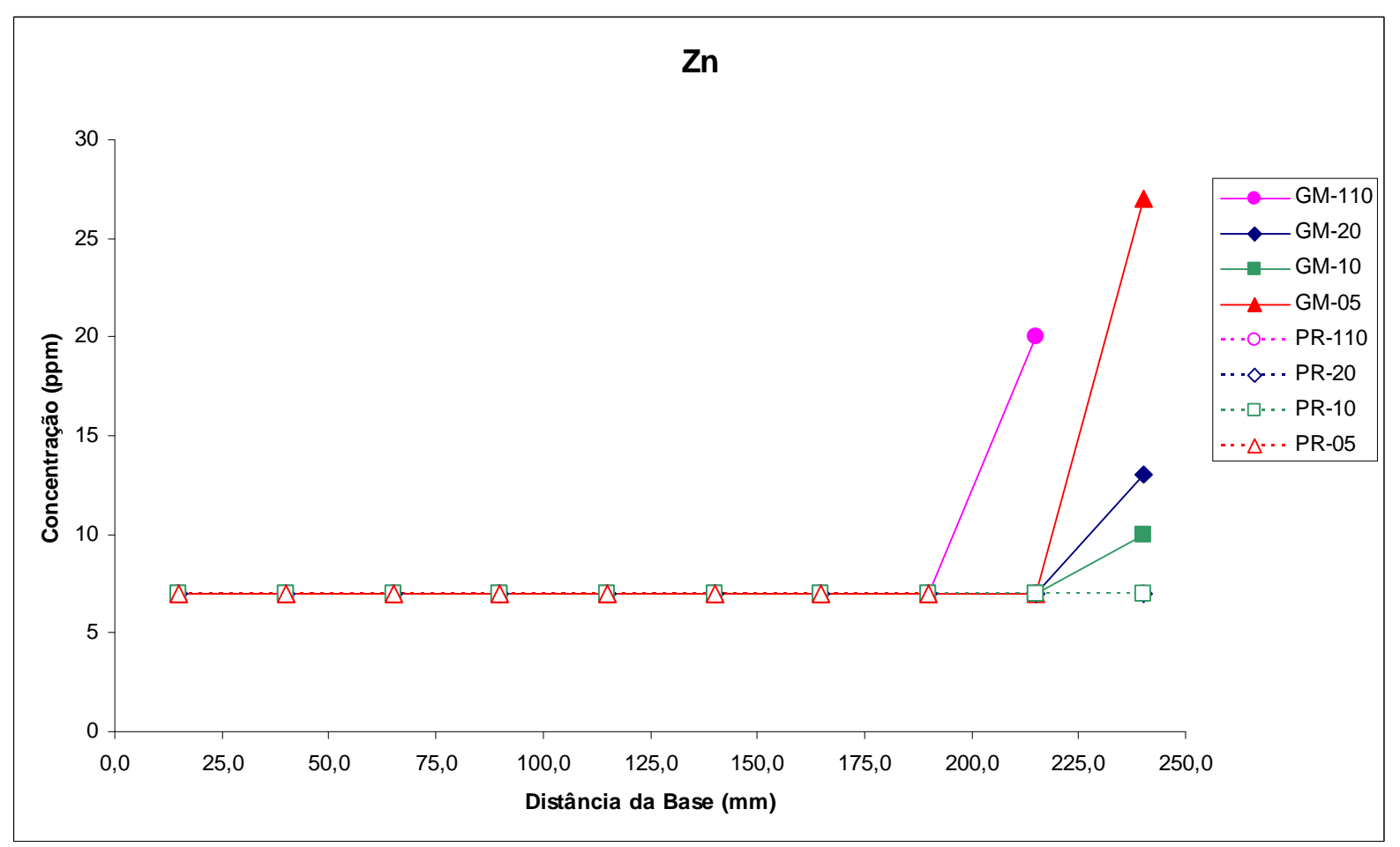

Figura 24a - Perfis de concentração do $\mathrm{Zn}$ ao longo dos lingotes obtidos por solidificação direcional do silício em diferentes concentrações iniciais e diferentes velocidades de extração do molde, segundo as condições definidas na Tabela 9.

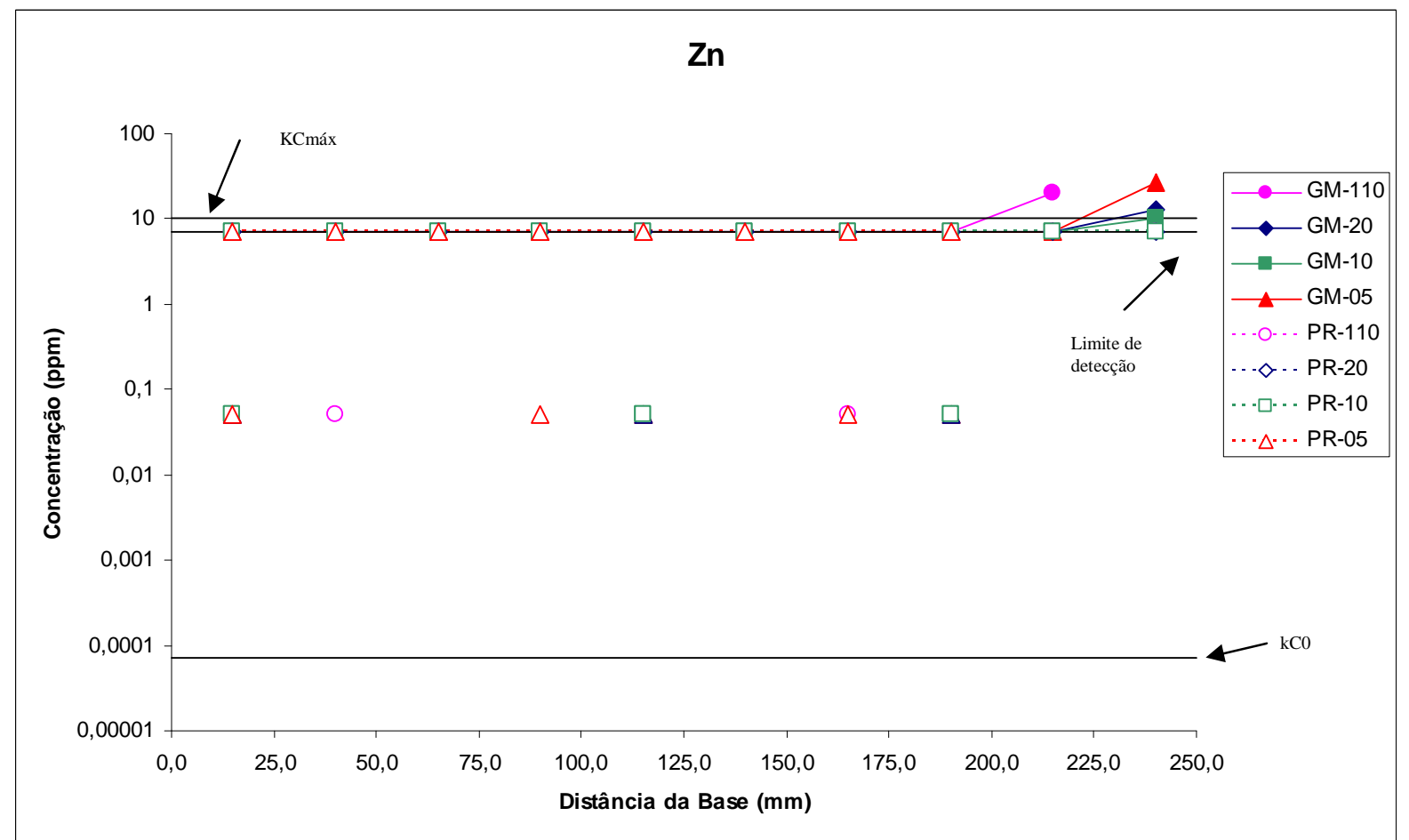

Figura 24b - Perfis de concentração do Zn (escala logarítmica) ao longo dos lingotes obtidos por solidificação direcional do silício em diferentes concentrações iniciais e diferentes velocidades de extração do molde, segundo as condições definidas na Tabela 9. 


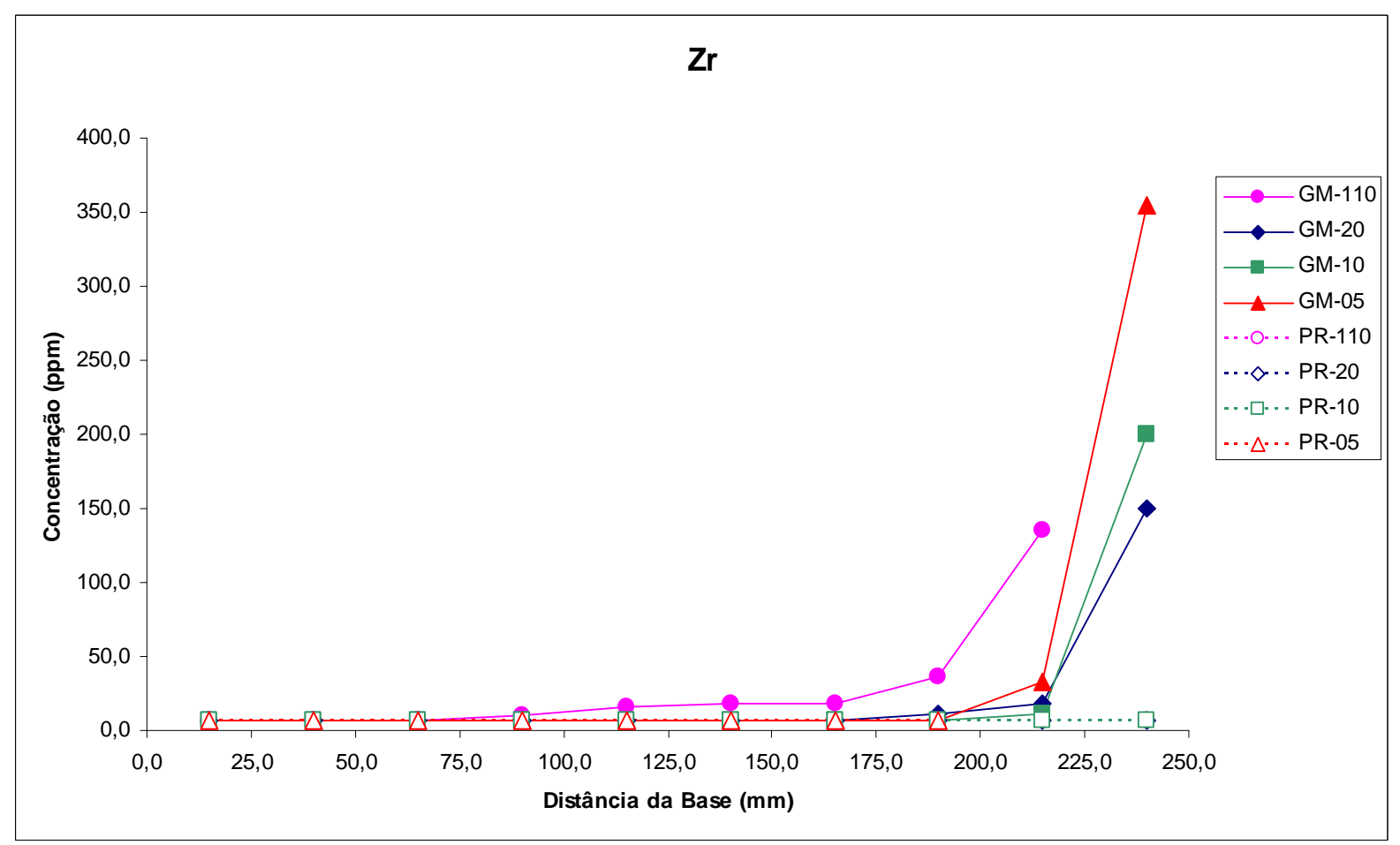

Figura 25a - Perfis de concentração do Zr ao longo dos lingotes obtidos por solidificação direcional do silício em diferentes concentrações iniciais e diferentes velocidades de extração do molde, segundo as condições definidas na Tabela 9.

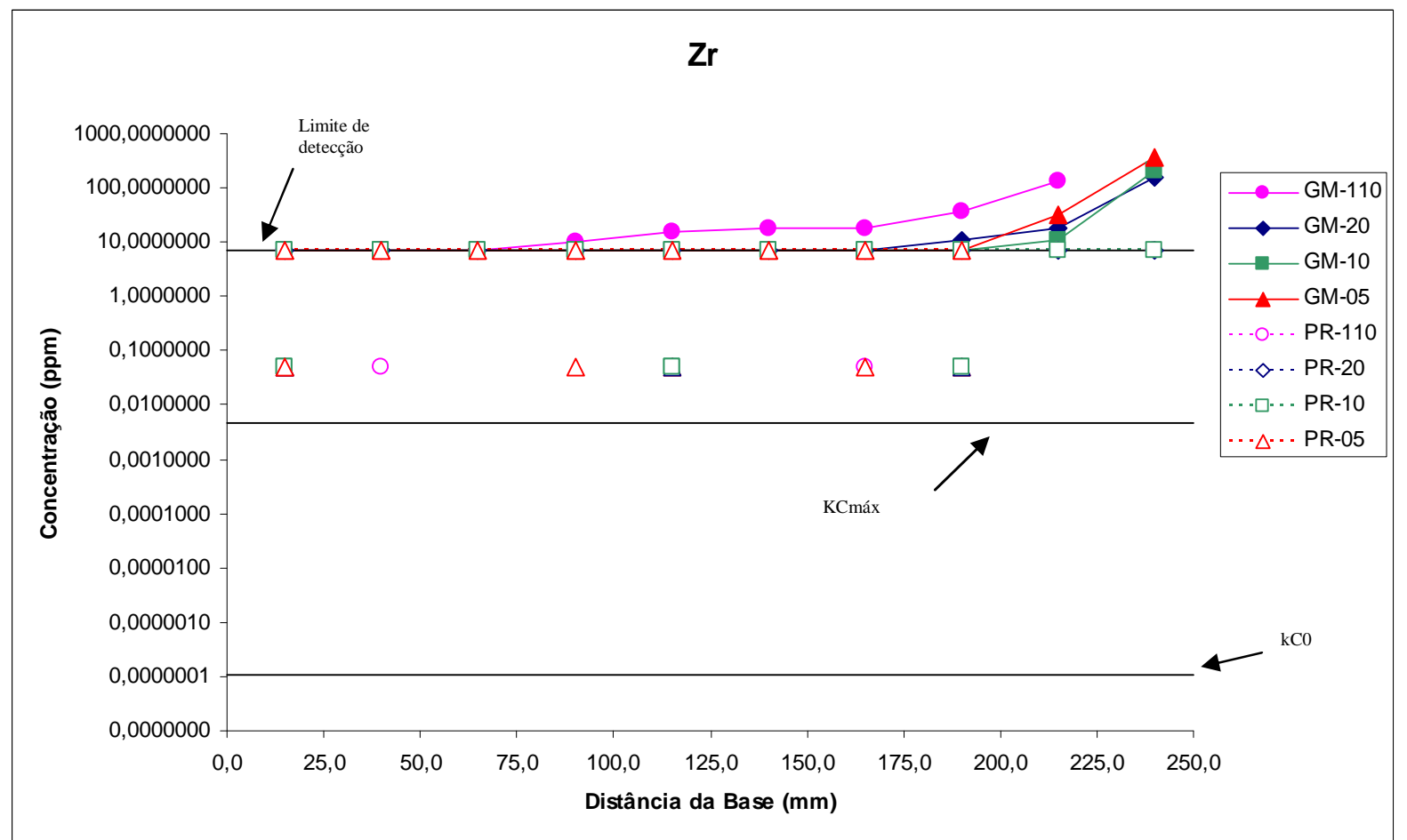

Figura 25b - Perfis de concentração do Zr (escala logarítmica) ao longo dos lingotes obtidos por solidificação direcional do silício em diferentes concentrações iniciais e diferentes velocidades de extração do molde, segundo as condições definidas na Tabela 9. 


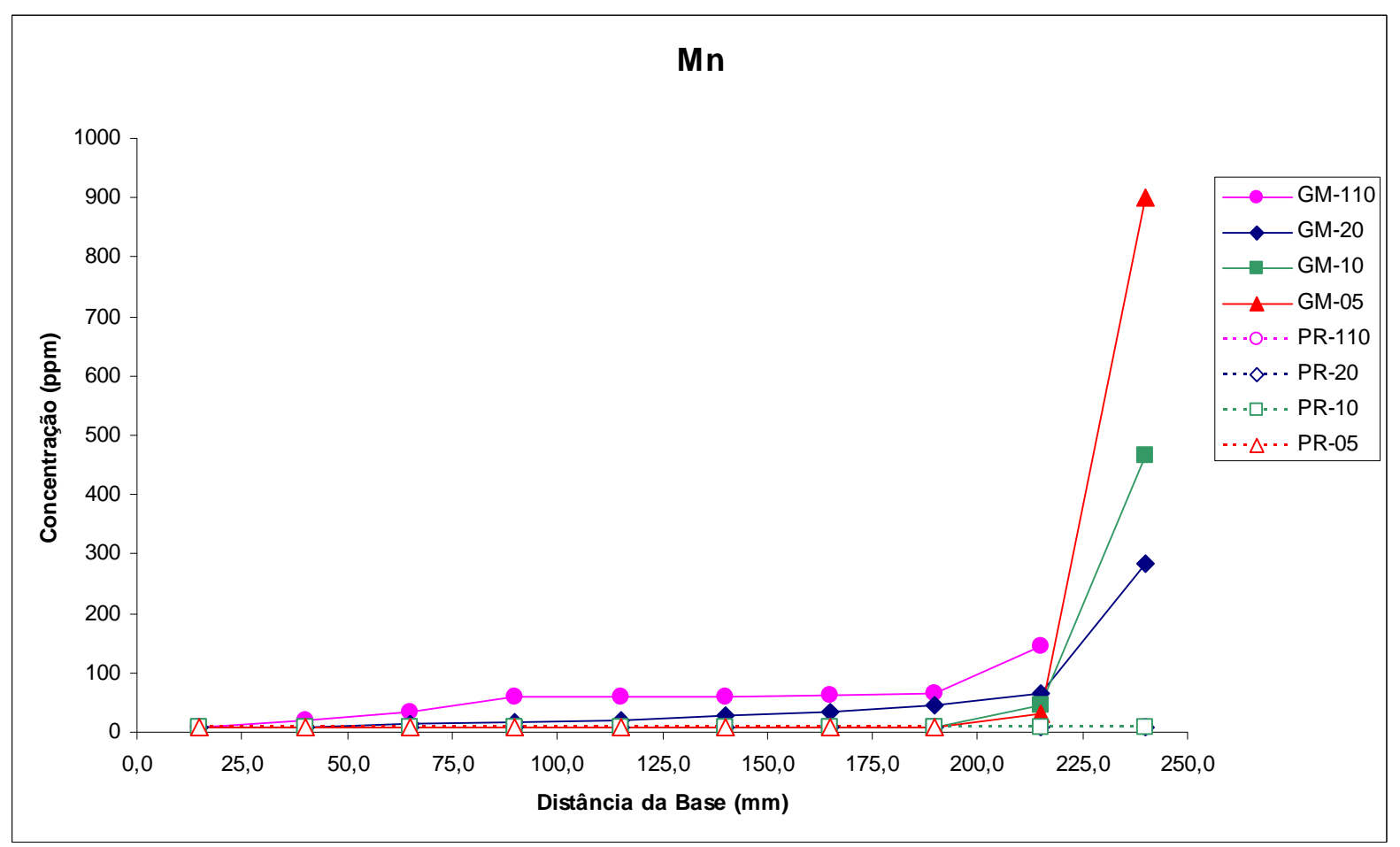

Figura 26a - Perfis de concentração do $\mathrm{Mn}$ ao longo dos lingotes obtidos por solidificação direcional do silício em diferentes concentrações iniciais e diferentes velocidades de extração do molde, segundo as condições definidas na Tabela 9.

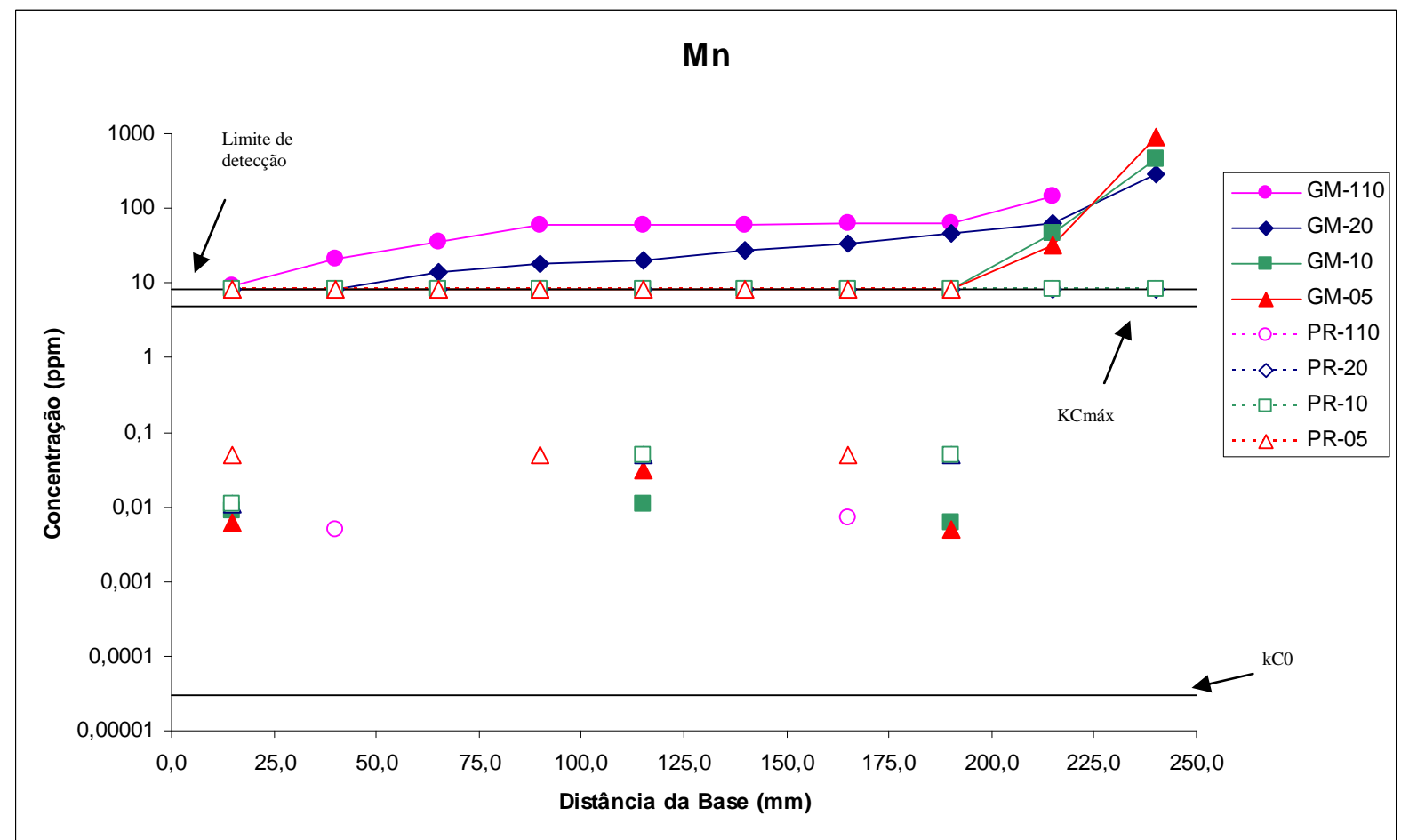

Figura 26b - Perfis de concentração do Mn (escala logarítmica) ao longo dos lingotes obtidos por solidificação direcional do silício em diferentes concentrações iniciais e diferentes velocidades de extração do molde, segundo as condições definidas na Tabela 9. 


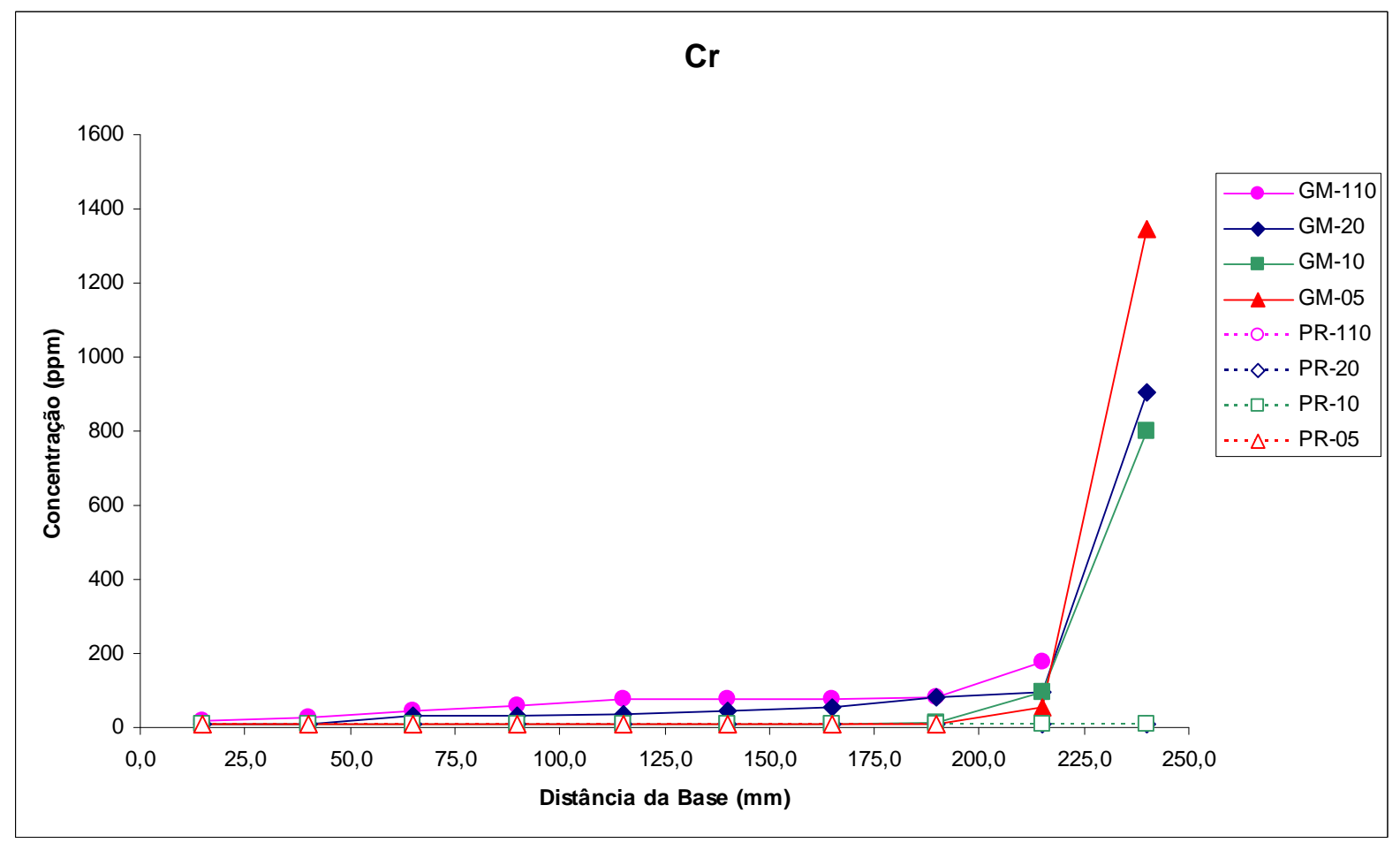

Figura 27a - Perfis de concentração do $\mathrm{Cr}$ ao longo dos lingotes obtidos por solidificação direcional do silício em diferentes concentrações iniciais e diferentes velocidades de extração do molde, segundo as condições definidas na Tabela 9.

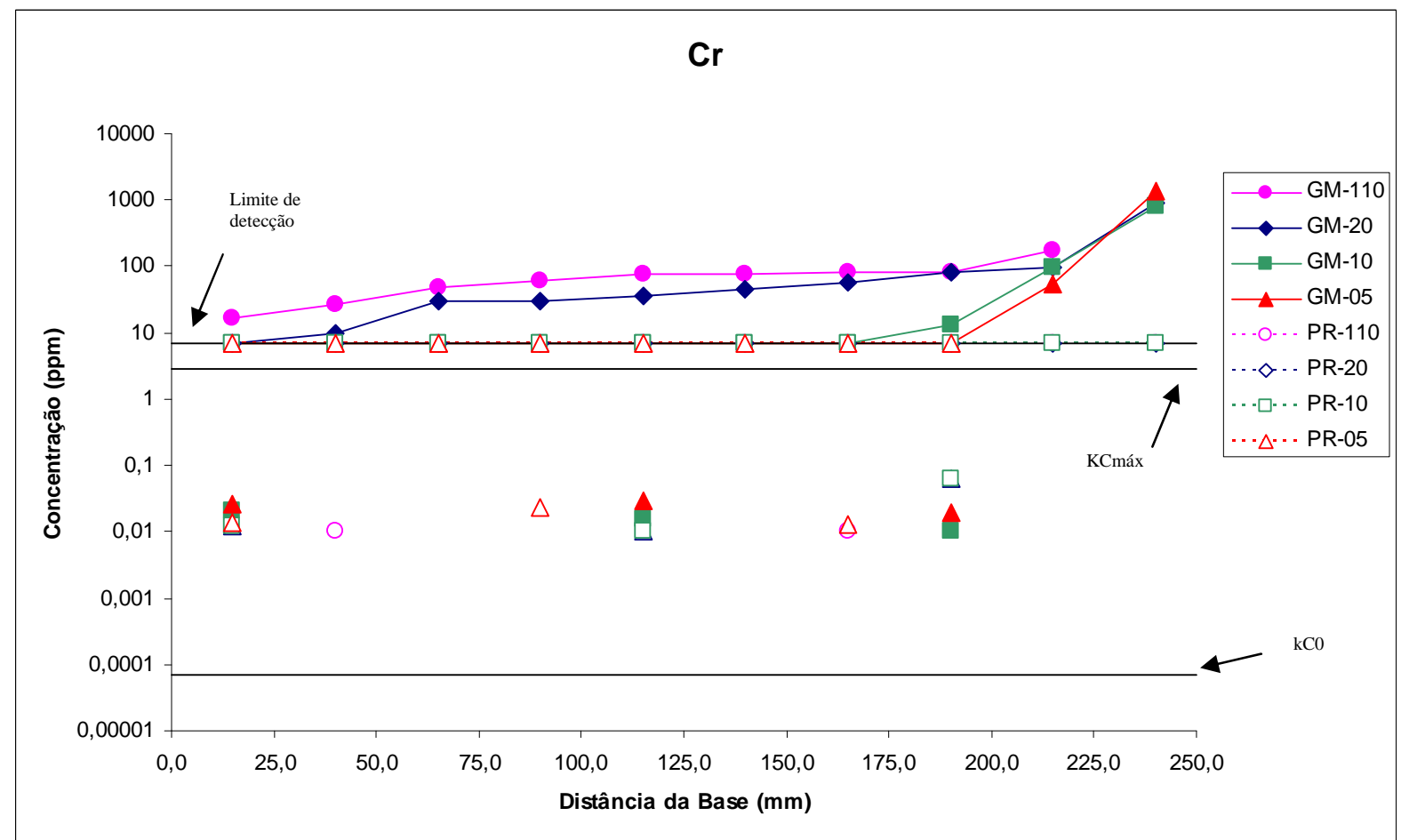

Figura 27b - Perfis de concentração do $\mathrm{Cr}$ (escala logarítmica) ao longo dos lingotes obtidos por solidificação direcional do silício em diferentes concentrações iniciais e diferentes velocidades de extração do molde, segundo as condições definidas na Tabela 9. 


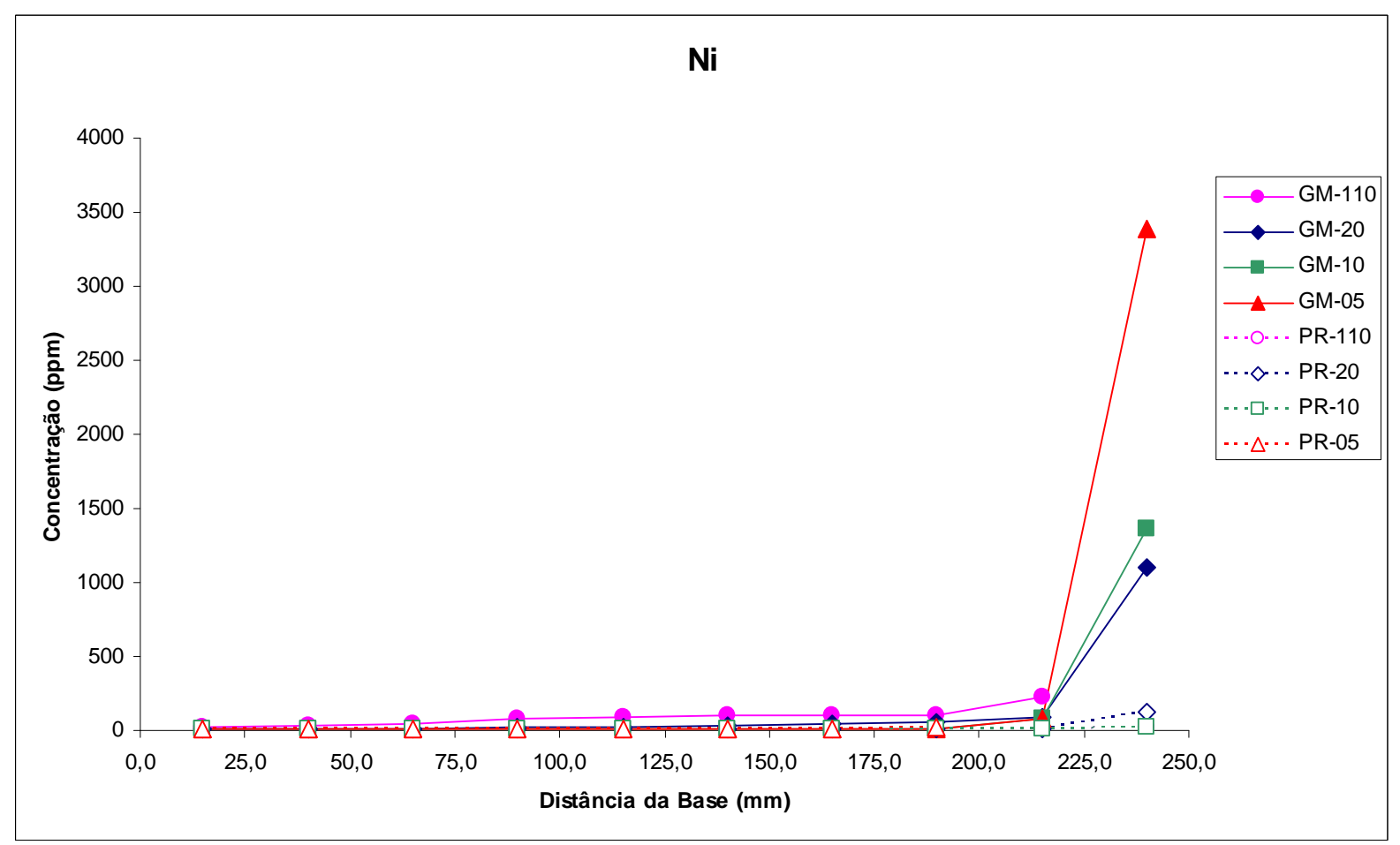

Figura 28a - Perfis de concentração do $\mathrm{Ni}$ ao longo dos lingotes obtidos por solidificação direcional do silício em diferentes concentrações iniciais e diferentes velocidades de extração do molde, segundo as condições definidas na Tabela 9.

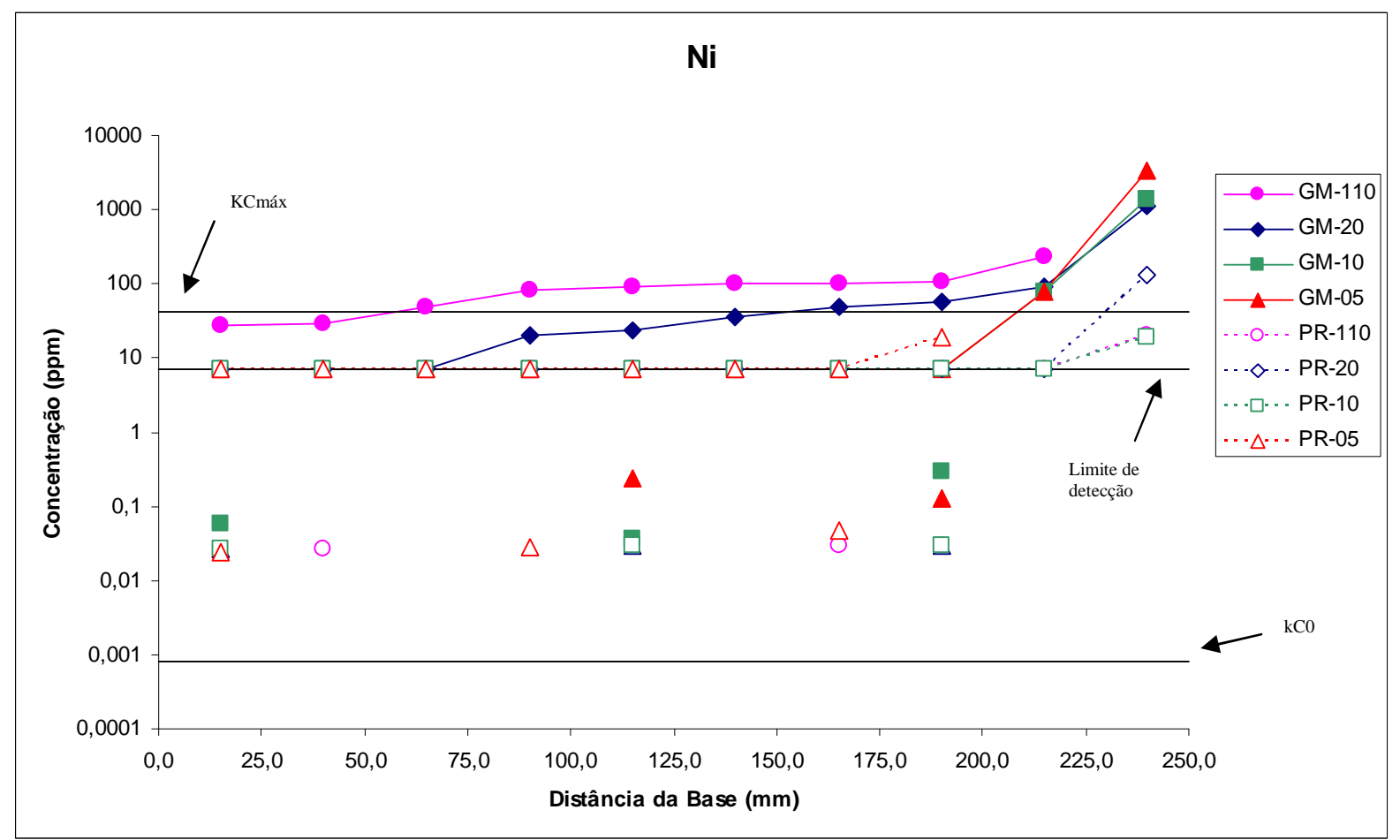

Figura 28b - Perfis de concentração do Ni (escala logarítmica) ao longo dos lingotes obtidos por solidificação direcional do silício em diferentes concentrações iniciais e diferentes velocidades de extração do molde, segundo as condições definidas na Tabela 9. 


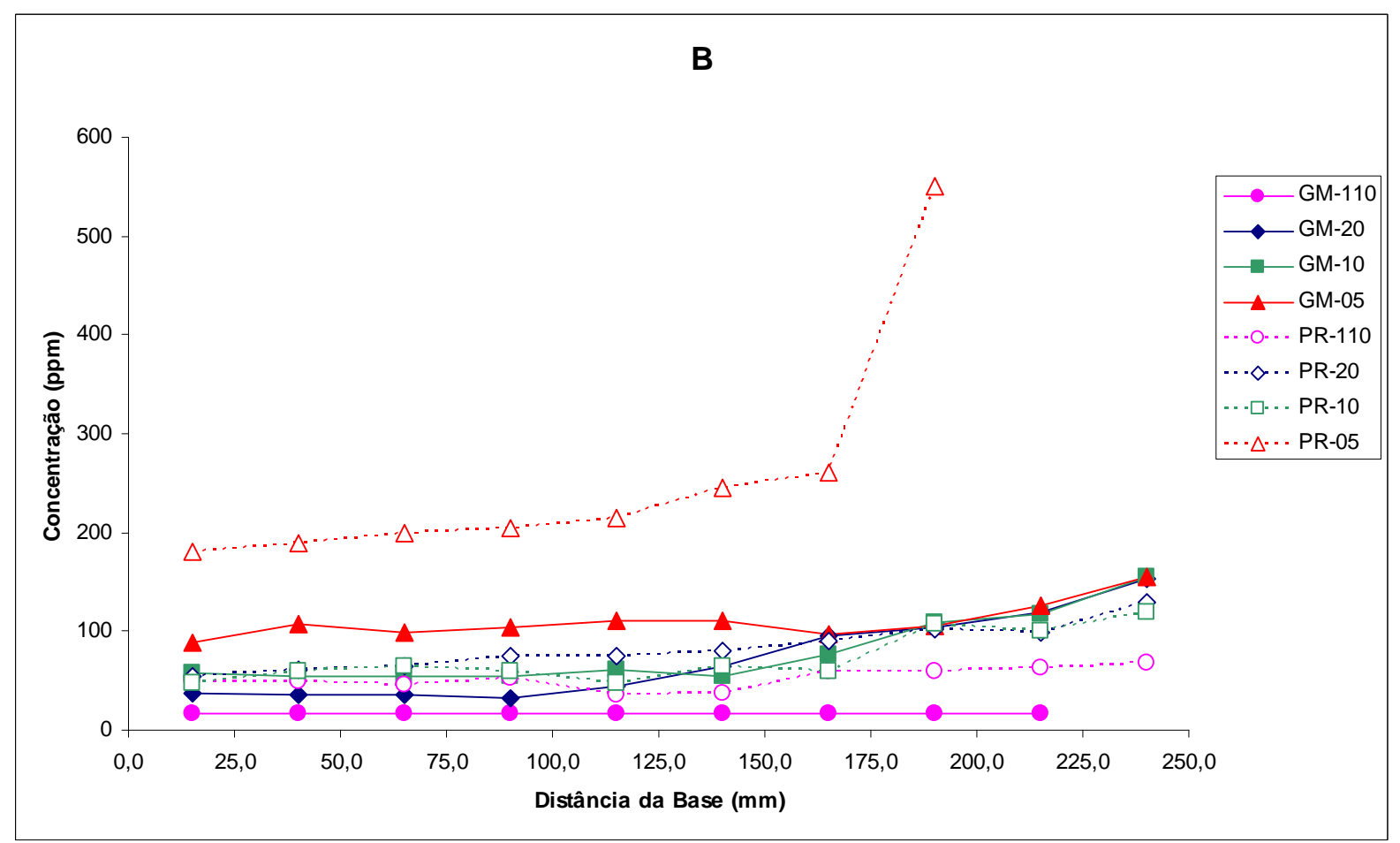

Figura 29a - Perfis de concentração do B ao longo dos lingotes obtidos por solidificação direcional do silício em diferentes concentrações iniciais e diferentes velocidades de extração do molde, segundo as condições definidas na Tabela 9.

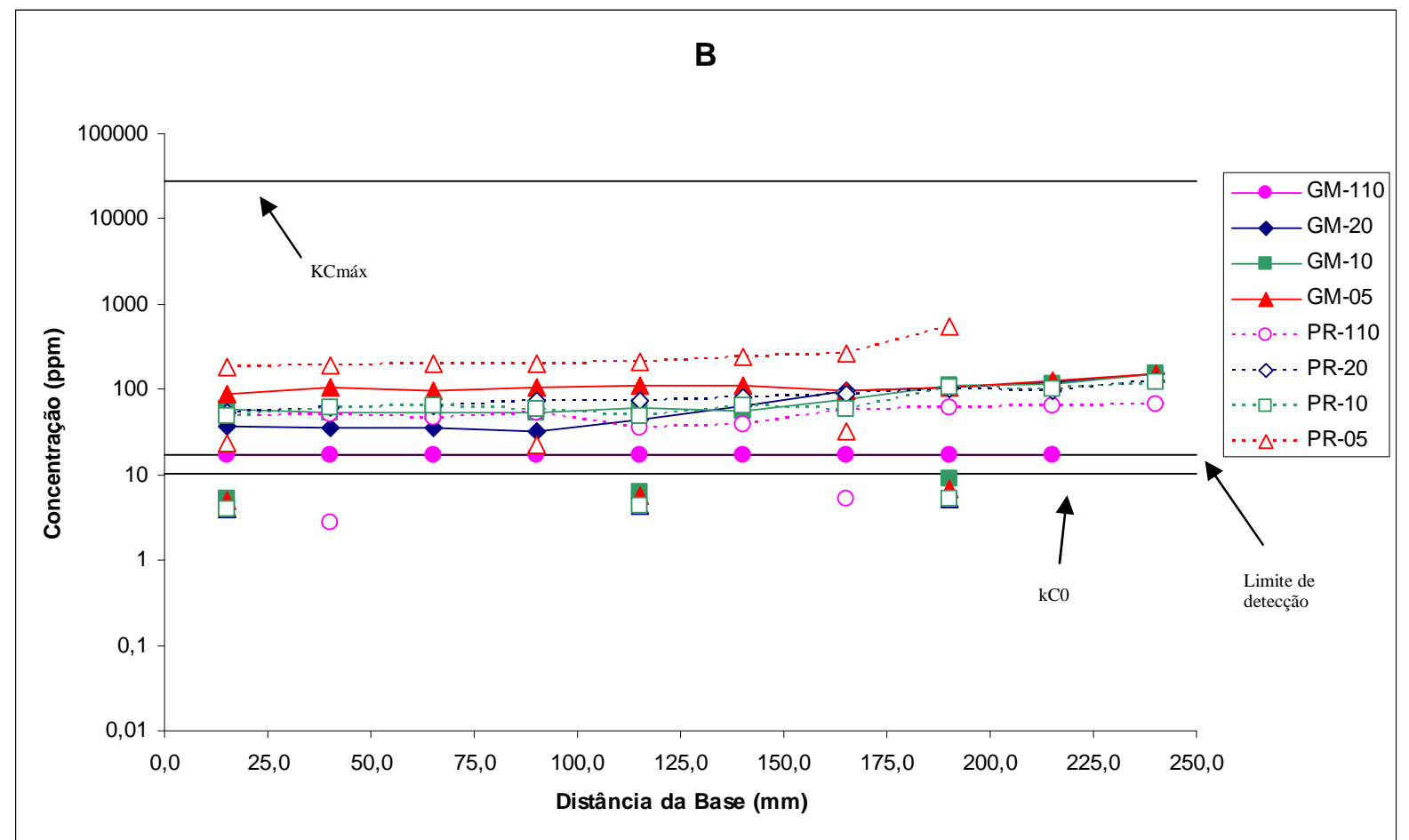

Figura 29b - Perfis de concentração do B (escala logarítmica) ao longo dos lingotes obtidos por solidificação direcional do silício em diferentes concentrações iniciais e diferentes velocidades de extração do molde, segundo as condições definidas na Tabela 9. 


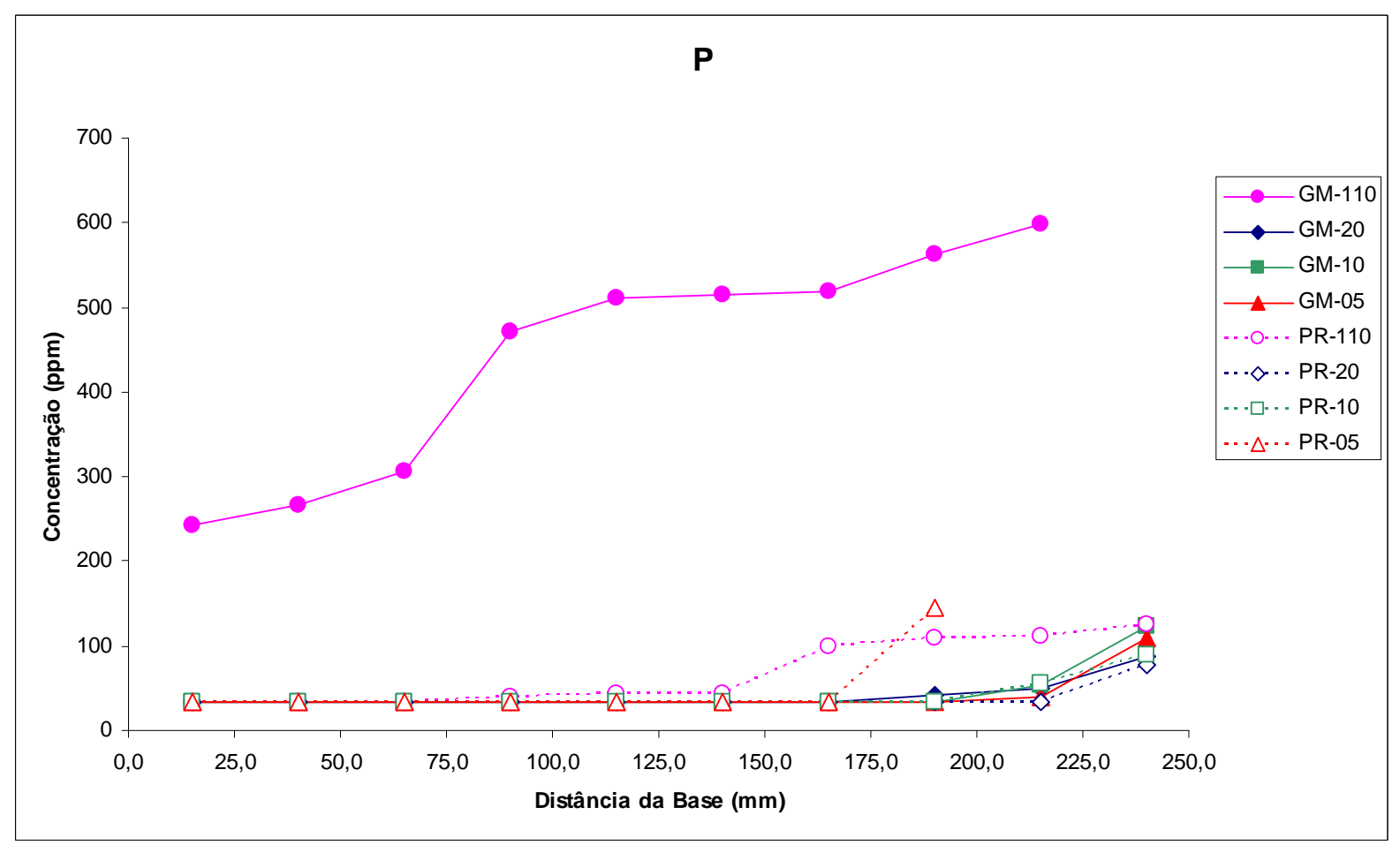

Figura 30a - Perfis de concentração do $\mathrm{P}$ ao longo dos lingotes obtidos por solidificação direcional do silício em diferentes concentrações iniciais e diferentes velocidades de extração do molde, segundo as condições definidas na Tabela 9.

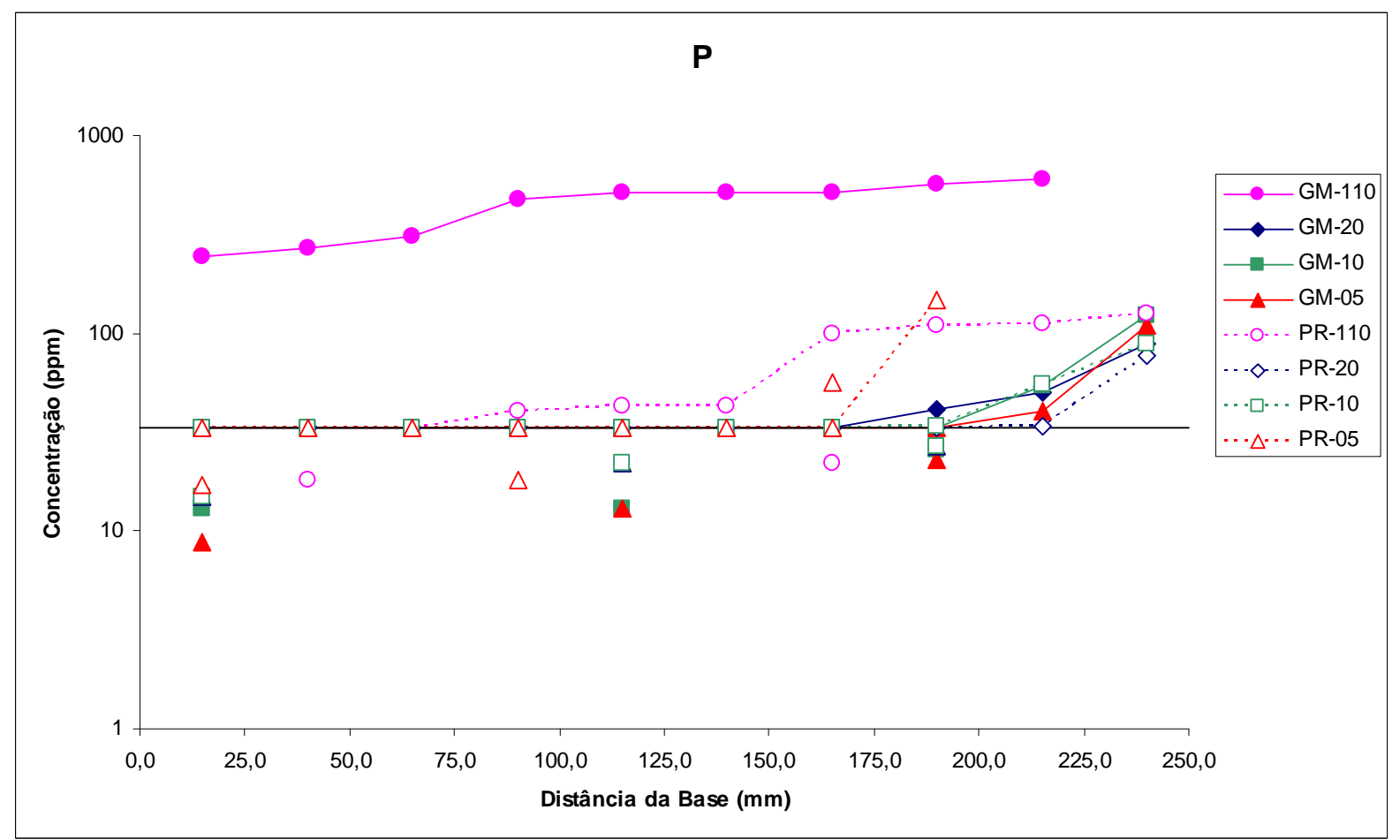

Figura 30b - Perfis de concentração do $P$ (escala logarítmica) ao longo dos lingotes obtidos por solidificação direcional do silício em diferentes concentrações iniciais e diferentes velocidades de extração do molde, segundo as condições definidas na Tabela 9. 


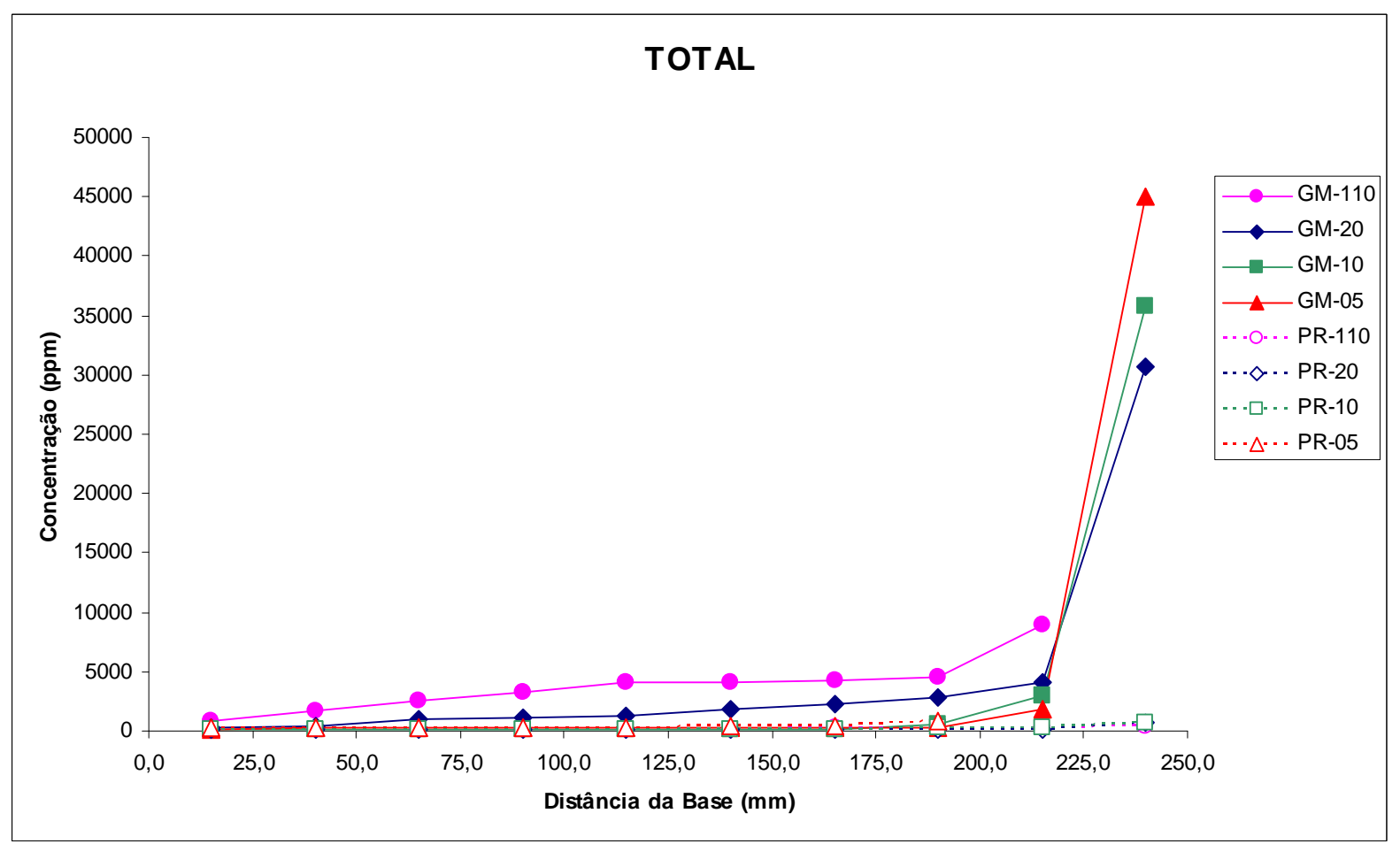

Figura 31a - Perfis de concentração total ao longo dos lingotes obtidos por solidificação direcional do silício em diferentes concentrações iniciais e diferentes velocidades de extração do molde, segundo as condições definidas na Tabela 9. Ensaios Definitivos

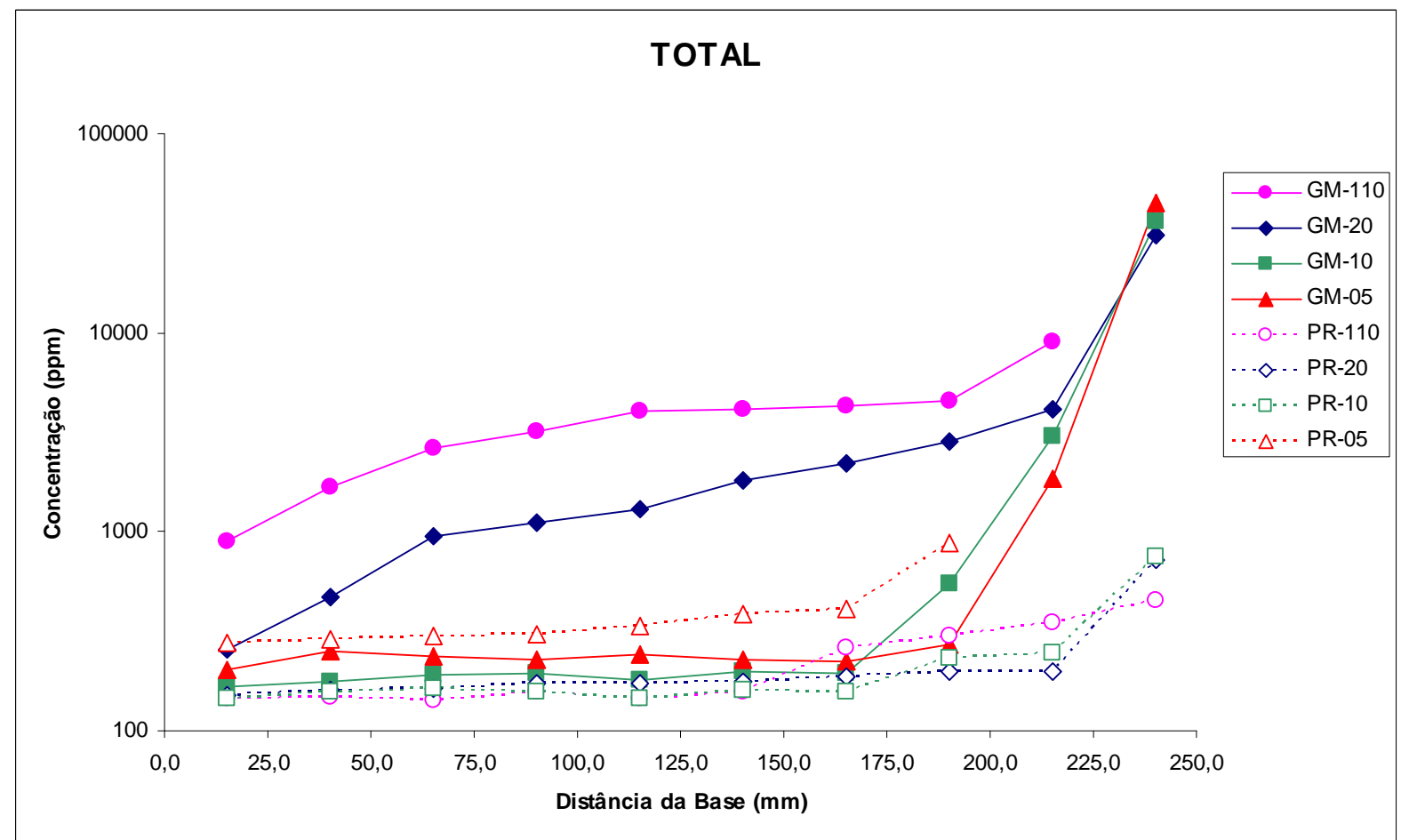

Figura 31b - Perfis de concentração total (escala logarítmica) ao longo dos lingotes obtidos por solidificação direcional do silício em diferentes concentrações iniciais e diferentes velocidades de extração do molde. Ensaios Definitivos 


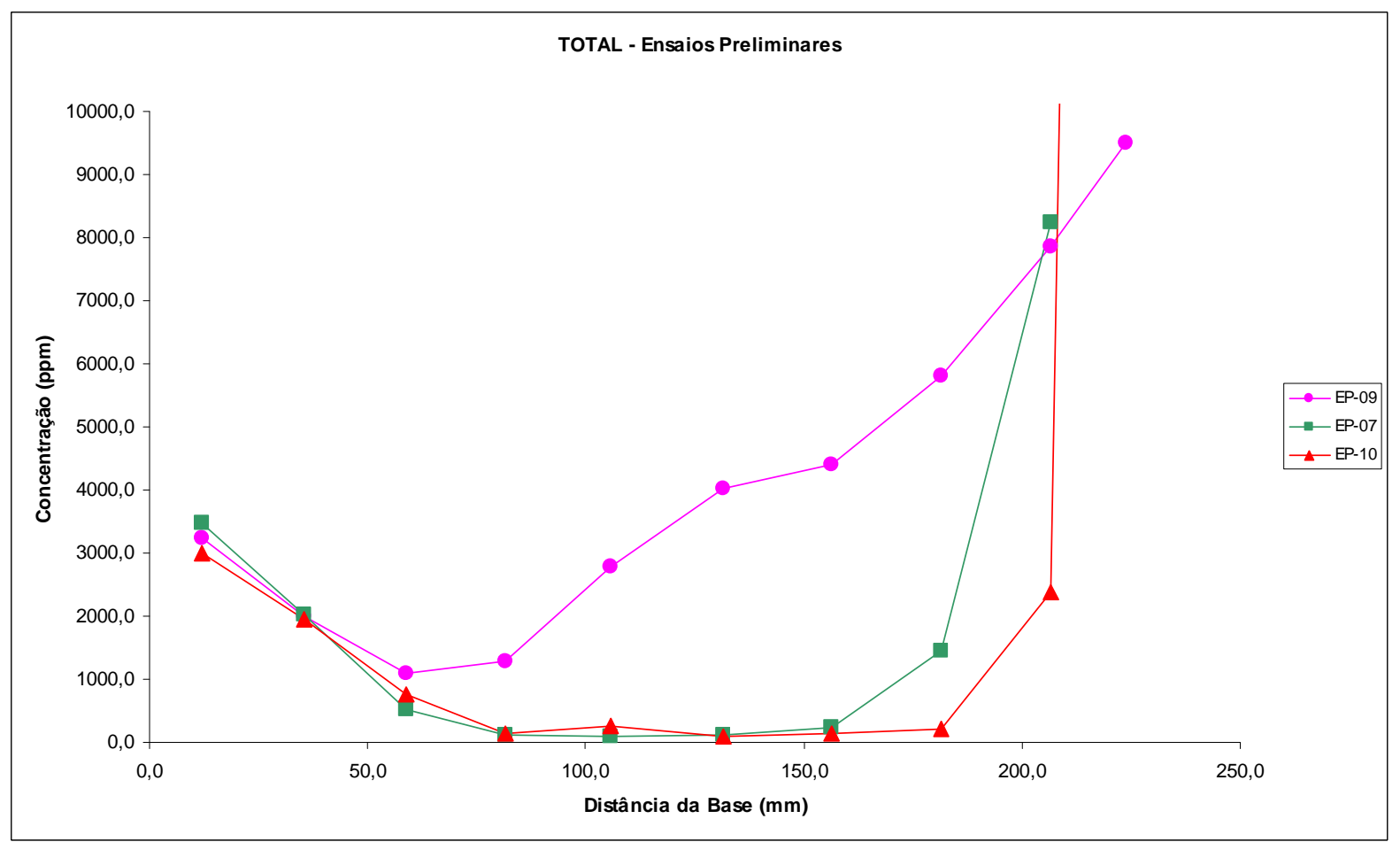

Figura 32a - Perfis de concentração total ao longo dos lingotes obtidos por solidificação direcional do silício em diferentes concentrações iniciais e diferentes velocidades de extração do molde,segundo as condições definidas na Tabela 8. Ensaios Preliminares

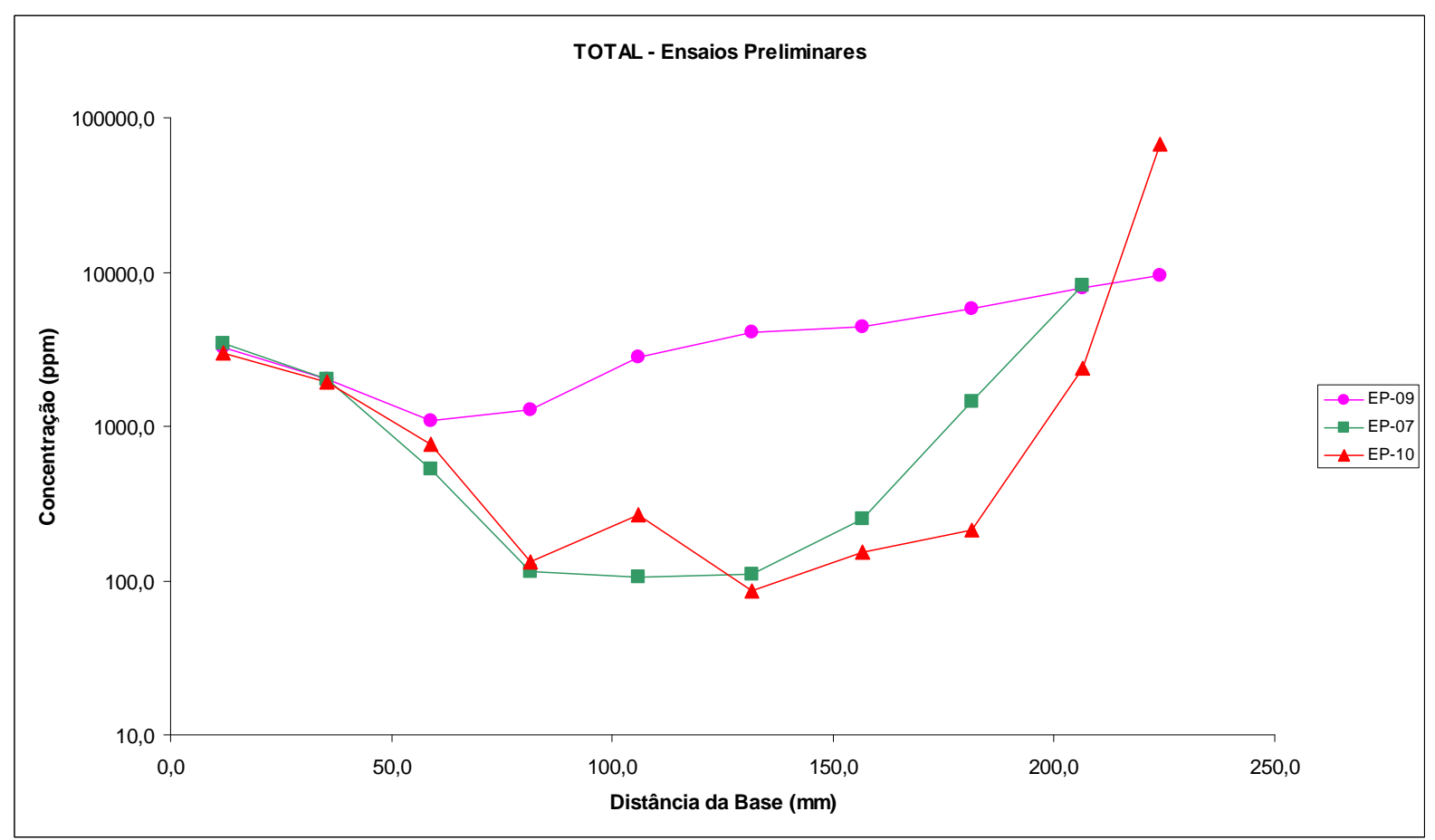

Figura 32b - Perfis de concentração total (escala logarítmica) ao longo dos lingotes obtidos por solidificação direcional do silício em diferentes concentrações iniciais e diferentes velocidades de extração do molde. Ensaios Preliminares 


\subsection{Análises Químicas por GDMS}

Neste subitem serão apresentados, em forma de tabelas, os resultados das análises químicas realizadas por GDMS, já apresentadas nas figuras do item anterior. As análises foram realizadas no Northern Analytical Laboratory de New Hampshire, Estados Unidos. Foram analisados os lingotes obtidos nos seguintes ensaios: GM-05, GM-10, PR-05, PR-20 e PR-110. A Tabela 11 mostra a posição onde as análises foram realizadas em cada lingote. Para facilitar a compreensão foi adicionado ao nome do lingote o número referente à posição da amostra onde a análise foi feita.

Tabela 11 - Posição referente a cada análise de silício por GDMS.

\begin{tabular}{|c|c|c|c|c|c|c|}
\hline & GM-05 & GM-10 & PR-05 & PR-10 & PR-20 & PR-110 \\
\hline $\begin{array}{c}\text { 10 } \\
\text { Topo }\end{array}$ & & & & & & \\
\hline 9 \\
\hline 8 \\
\hline 9
\end{tabular}


As Tabelas 12 a 27 mostram os resultados das análises químicas por GDMS. Os elementos H, N, O, F, Sc, Br, Rb, Sr, Y, Ru, Rh, Pd, Cd, In, Te, I, Cs, Ba, La, Ce, Pr, Sm, Nd, Eu, Gd, Tb, Dy, Ho, Er, Tm, Yb, Lu, Hf, Ta, Re, Os, Ir, Pt, Au, Hg, Tl, possuem concentração abaixo de 0,1 ppm, sem uma definição exata do valor, portanto não foram incluídos na tabela. 
Tabela 12 - Resultados da análise por GDMS da amostra GM - 05/1 (Base)

Elemento

$\mathrm{Li}$

$\mathrm{Be}$

B

$\mathrm{F}$

$\mathrm{Na}$

$\mathrm{Mg}$

Al

Si

$P$

$\mathrm{S}$

$\mathrm{Cl}$

$\mathrm{K}$

$\mathrm{Ca}$

$\mathrm{Ti}$

V

$\mathrm{Cr}$

$\mathrm{Mn}$

$\mathrm{Fe}$ ppmw

$<0.05$

$<0.05$

5.0

$<0.3$

0.064

0.018

0.50

Matriz

8.8

0.062

$<0.5$

0.097

$<0.1$

0.002

$<0.001$

0.026

0.006

0.14

\section{Elemento}

Co

$\mathrm{Ni}$

$\mathrm{Cu}$

Zn

$\mathrm{Ge}$

As

$\mathrm{Se}$

$\mathrm{Zr}$

$\mathrm{Nb}$

Mo

Ag

Sn

$\mathrm{Sb}$

W

$\mathrm{Pb}$

$\mathrm{Bi}$

Th

U ppmw

$<0.01$

0.026

$<0.05$

$<0.05$

$<0.5$

0.13

$<0.3$

$<0.05$

$<0.05$

$<0.05$

$<0.2$

$<0.2$

$<0.2$

$<0.03$

$<0.05$

$<0.03$

$<0.01$

$<0.01$

Tabela 13 - Resultados da análise por GDMS da amostra GM - 05/5 (Centro)

\section{Elemento}

$\mathrm{Li}$

$\mathrm{Be}$

B

$\mathrm{F}$

$\mathrm{Na}$

$\mathrm{Mg}$

Al

Si

$P$

$\mathrm{S}$

$\mathrm{Cl}$

$\mathrm{K}$

$\mathrm{Ca}$

$\mathrm{Ti}$

V

$\mathrm{Cr}$

$\mathrm{Mn}$

$\mathrm{Fe}$ ppmw

$<0.05$

$<0.05$

5.6

$<0.3$

0.13

$<0.01$

0.91

Matriz

13

0.039

$<0.5$

0.12

$<0.1$

0,083

0.004

0.029

0.031

1,6

\section{Elemento}

Co

$\mathrm{Ni}$

$\mathrm{Cu}$

$\mathrm{Zn}$

$\mathrm{Ge}$

As

$\mathrm{Se}$

$\mathrm{Zr}$

$\mathrm{Nb}$

Mo

$\mathrm{Ag}$

Sn

$\mathrm{Sb}$

W

$\mathrm{Pb}$

$\mathrm{Bi}$

Th

U ppmw

$<0.01$

0,024

$<0.05$

$<0.05$

$<0.5$

0.012

$<0.3$

$<0.05$

$<0.05$

$<0.05$

$<0.2$

$<0.2$

$<0.2$

$<0.03$

$<0.05$

$<0.03$

$<0.01$

$<0.01$ 
Tabela 14 - Resultados da análise por GDMS da amostra GM - 05/8

$\begin{array}{cccc}\text { Elemento } & \text { ppmw } & \text { Elemento } & \text { ppmw } \\ \mathrm{Li} & <0.05 & \mathrm{Co} & <0.01 \\ \mathrm{Be} & <0.05 & \mathrm{Ni} & 0.13 \\ \mathrm{~B} & 6.7 & \mathrm{Cu} & 0.90 \\ \mathrm{~F} & <0.3 & \mathrm{Zn} & <0.05 \\ \mathrm{Na} & 0.14 & \mathrm{Ge} & <0.5 \\ \mathrm{Mg} & <0.01 & \mathrm{As} & 0.091 \\ \mathrm{Al} & 1.6 & \mathrm{Se} & <0.3 \\ \mathrm{Si} & \mathrm{Matriz} & \mathrm{Zr} & <0.05 \\ \mathrm{P} & 23 & \mathrm{Nb} & <0.05 \\ \mathrm{~S} & 0.022 & \mathrm{Mo} & <0.05 \\ \mathrm{Cl} & <0.5 & \mathrm{Ag} & <0.2 \\ \mathrm{~K} & 0.063 & \mathrm{Sn} & <0.2 \\ \mathrm{Ca} & <0.1 & \mathrm{Sb} & <0.2 \\ \mathrm{Ti} & 0.002 & \mathrm{~W} & <0.03 \\ \mathrm{~V} & <0.001 & \mathrm{~Pb} & <0.05 \\ \mathrm{Cr} & 0.020 & \mathrm{Bi} & <0.03 \\ \mathrm{Mn} & 0.005 & \mathrm{Th} & <0.01 \\ \mathrm{Fe} & 0.26 & \mathrm{U} & <0.01\end{array}$

Tabela 15 - Resultados da análise por GDMS da amostra PR - 05/1.

$\begin{array}{cccc}\text { Elemento } & \text { ppmw } & \text { Elemento } & \text { ppmw } \\ \mathrm{Li} & <0.05 & \mathrm{Co} & <0.01 \\ \mathrm{Be} & <0.05 & \mathrm{Ni} & 0.024 \\ \mathrm{~B} & 23 & \mathrm{Cu} & <0.05 \\ \mathrm{~F} & <0.3 & \mathrm{Zn} & <0.05 \\ \mathrm{Na} & 0.26 & \mathrm{Ge} & <0.5 \\ \mathrm{Mg} & 0.017 & \mathrm{As} & 0.12 \\ \mathrm{Al} & 0.98 & \mathrm{Se} & <0.3 \\ \mathrm{Si} & \mathrm{Matriz} & \mathrm{Zr} & <0.05 \\ \mathrm{P} & 17 & \mathrm{Nb} & <0.05 \\ \mathrm{~S} & 0.037 & \mathrm{Mo} & <0.05 \\ \mathrm{Cl} & <0.5 & \mathrm{Ag} & <0.2 \\ \mathrm{~K} & 0.17 & \mathrm{Sn} & <0.2 \\ \mathrm{Ca} & 0.12 & \mathrm{Sb} & <0.2 \\ \mathrm{Ti} & 0.004 & \mathrm{~W} & <0.03 \\ \mathrm{~V} & 0.003 & \mathrm{~Pb} & <0.05 \\ \mathrm{Cr} & 0.014 & \mathrm{Bi} & <0.03 \\ \mathrm{Mn} & 0.011 & \mathrm{Th} & <0.01 \\ \mathrm{Fe} & 0.17 & \mathrm{U} & <0.01\end{array}$


Tabela 16 - Resultados da análise por GDMS da amostra PR - 05/4.

$\begin{array}{cccc}\text { Elemento } & \text { ppmw } & \text { Elemento } & \text { ppmw } \\ \mathrm{Li} & <0.05 & \mathrm{Co} & <0.01 \\ \mathrm{Be} & <0.05 & \mathrm{Ni} & 0.028 \\ \mathrm{~B} & 22 & \mathrm{Cu} & <0.05 \\ \mathrm{~F} & <0.3 & \mathrm{Zn} & <0.05 \\ \mathrm{Na} & 0.10 & \mathrm{Ge} & <0.5 \\ \mathrm{Mg} & <0.01 & \mathrm{As} & <0.05 \\ \mathrm{Al} & 1.2 & \mathrm{Se} & <0.3 \\ \mathrm{Si} & \mathrm{Matriz} & \mathrm{Zr} & <0.05 \\ \mathrm{P} & 18 & \mathrm{Nb} & <0.05 \\ \mathrm{~S} & 0.065 & \mathrm{Mo} & <0.05 \\ \mathrm{Cl} & <0.5 & \mathrm{Ag} & <0.2 \\ \mathrm{~K} & 0.14 & \mathrm{Sn} & <0.2 \\ \mathrm{Ca} & <0.1 & \mathrm{Sb} & <0.2 \\ \mathrm{Ti} & 0.002 & \mathrm{~W} & <0.03 \\ \mathrm{~V} & 0.002 & \mathrm{~Pb} & <0.05 \\ \mathrm{Cr} & 0.023 & \mathrm{Bi} & <0.03 \\ \mathrm{Mn} & <0.005 & \mathrm{Th} & <0.01 \\ \mathrm{Fe} & 0.092 & \mathrm{U} & <0.01\end{array}$

Tabela 17 - Resultados da análise por GDMS da amostra PR - 05/7.

$\begin{array}{cccc}\text { Elemento } & \text { ppmw } & \text { Elemento } & \text { ppmw } \\ \mathrm{Li} & <0.05 & \mathrm{Co} & <0.01 \\ \mathrm{Be} & <0.05 & \mathrm{Ni} & 0.047 \\ \mathrm{~B} & 32 & \mathrm{Cu} & <0.05 \\ \mathrm{~F} & <0.3 & \mathrm{Zn} & <0.05 \\ \mathrm{Na} & 0.26 & \mathrm{Ge} & <0.5 \\ \mathrm{Mg} & 0.019 & \mathrm{As} & 0.052 \\ \mathrm{Al} & 5.2 & \mathrm{Se} & <0.3 \\ \mathrm{Si} & \mathrm{Matriz} & \mathrm{Zr} & <0.05 \\ \mathrm{P} & 56 & \mathrm{Nb} & <0.05 \\ \mathrm{~S} & 0.025 & \mathrm{Mo} & <0.05 \\ \mathrm{Cl} & <0.5 & \mathrm{Ag} & <0.2 \\ \mathrm{~K} & 0.12 & \mathrm{Sn} & <0.2 \\ \mathrm{Ca} & <0.1 & \mathrm{Sb} & <0.2 \\ \mathrm{Ti} & 0.003 & \mathrm{~W} & <0.03 \\ \mathrm{~V} & 0.002 & \mathrm{~Pb} & <0.05 \\ \mathrm{Cr} & 0.013 & \mathrm{Bi} & <0.03 \\ \mathrm{Mn} & <0.005 & \mathrm{Th} & <0.01 \\ \mathrm{Fe} & 0.13 & \mathrm{U} & <0.01\end{array}$


Tabela 18 - Resultados da análise por GDMS da amostra GM - 10/1.

$\begin{array}{cccc}\text { Elemento } & \text { ppmw } & \text { Elemento } & \text { ppmw } \\ \mathrm{Li} & <0.05 & \mathrm{Co} & <0.01 \\ \mathrm{Be} & <0.05 & \mathrm{Ni} & 0.058 \\ \mathrm{~B} & 5.2 & \mathrm{Cu} & <0.05 \\ \mathrm{~F} & <0.3 & \mathrm{Zn} & <0.05 \\ \mathrm{Na} & 0.12 & \mathrm{Ge} & <0.5 \\ \mathrm{Mg} & 0.027 & \mathrm{As} & 0.048 \\ \mathrm{Al} & 0.56 & \mathrm{Se} & <0.3 \\ \mathrm{Si} & \mathrm{Matriz} & \mathrm{Zr} & <0.05 \\ \mathrm{P} & 13 & \mathrm{Nb} & <0.05 \\ \mathrm{~S} & 0.021 & \mathrm{Mo} & <0.05 \\ \mathrm{Cl} & <0.5 & \mathrm{Ag} & <0.2 \\ \mathrm{~K} & 0.20 & \mathrm{Sn} & <0.2 \\ \mathrm{Ca} & <0.1 & \mathrm{Sb} & <0.2 \\ \mathrm{Ti} & 0.001 & \mathrm{~W} & <0.03 \\ \mathrm{~V} & 0.003 & \mathrm{~Pb} & <0.05 \\ \mathrm{Cr} & 0.021 & \mathrm{Bi} & <0.03 \\ \mathrm{Mn} & 0.009 & \mathrm{Th} & <0.01 \\ \mathrm{Fe} & 0.29 & \mathrm{U} & <0.01\end{array}$

Tabela 19 - Resultados da análise por GDMS da amostra GM - 10/5.

$\begin{array}{cccc}\text { Elemento } & \text { ppmw } & \text { Elemento } & \text { ppmw } \\ \mathrm{Li} & <0.05 & \mathrm{Co} & <0.01 \\ \mathrm{Be} & <0.05 & \mathrm{Ni} & 0.037 \\ \mathrm{~B} & 6.2 & \mathrm{Cu} & 0.072 \\ \mathrm{~F} & <0.3 & \mathrm{Zn} & <0.05 \\ \mathrm{Na} & 0.20 & \mathrm{Ge} & <0.5 \\ \mathrm{Mg} & <0.01 & \mathrm{As} & 0.086 \\ \mathrm{Al} & 0.71 & \mathrm{Se} & <0.3 \\ \mathrm{Si} & \mathrm{Matriz} & \mathrm{Zr} & <0.05 \\ \mathrm{P} & 13 & \mathrm{Nb} & <0.05 \\ \mathrm{~S} & 0.038 & \mathrm{Mo} & <0.05 \\ \mathrm{Cl} & <0.5 & \mathrm{Ag} & <0.2 \\ \mathrm{~K} & 0.18 & \mathrm{Sn} & <0.2 \\ \mathrm{Ca} & <0.1 & \mathrm{Sb} & <0.2 \\ \mathrm{Ti} & 0.001 & \mathrm{~W} & <0.03 \\ \mathrm{~V} & 0.002 & \mathrm{~Pb} & <0.05 \\ \mathrm{Cr} & 0.015 & \mathrm{Bi} & <0.03 \\ \mathrm{Mn} & 0.011 & \mathrm{Th} & <0.01 \\ \mathrm{Fe} & 0.13 & \mathrm{U} & <0.01\end{array}$


Tabela 20 - Resultados da análise por GDMS da amostra GM - 10/8.

$\begin{array}{cccc}\text { Elemento } & \text { ppmw } & \text { Elemento } & \text { ppmw } \\ \mathrm{Li} & <0.05 & \mathrm{Co} & <0.01 \\ \mathrm{Be} & <0.05 & \mathrm{Ni} & 0.30 \\ \mathrm{~B} & 9.2 & \mathrm{Cu} & 2.2 \\ \mathrm{~F} & <0.3 & \mathrm{Zn} & <0.05 \\ \mathrm{Na} & 0.10 & \mathrm{Ge} & <0.5 \\ \mathrm{Mg} & <0.01 & \mathrm{As} & <0.05 \\ \mathrm{Al} & 1.9 & \mathrm{Se} & <0.3 \\ \mathrm{Si} & \mathrm{Matriz} & \mathrm{Zr} & <0.05 \\ \mathrm{P} & 26 & \mathrm{Nb} & <0.05 \\ \mathrm{~S} & 0.023 & \mathrm{Mo} & <0.05 \\ \mathrm{Cl} & <0.5 & \mathrm{Ag} & <0.2 \\ \mathrm{~K} & 0.085 & \mathrm{Sn} & <0.2 \\ \mathrm{Ca} & <0.1 & \mathrm{Sb} & <0.2 \\ \mathrm{Ti} & 0.001 & \mathrm{~W} & <0.03 \\ \mathrm{~V} & 0.001 & \mathrm{~Pb} & <0.05 \\ \mathrm{Cr} & 0.010 & \mathrm{Bi} & <0.03 \\ \mathrm{Mn} & 0.006 & \mathrm{Th} & <0.01 \\ \mathrm{Fe} & 0.16 & \mathrm{U} & <0.01\end{array}$

Tabela 21 - Resultados da análise por GDMS da amostra PR - 10/1.

$\begin{array}{cccc}\text { Elemento } & \text { ppmw } & \text { Elemento } & \text { ppmw } \\ \mathrm{Li} & <0.05 & \mathrm{Co} & <0.01 \\ \mathrm{Be} & <0.05 & \mathrm{Ni} & 0.027 \\ \mathrm{~B} & 4.0 & \mathrm{Cu} & 0.061 \\ \mathrm{~F} & <0.3 & \mathrm{Zn} & <0.05 \\ \mathrm{Na} & 0.21 & \mathrm{Ge} & <0.5 \\ \mathrm{Mg} & \leq 0.01 & \mathrm{As} & <0.05 \\ \mathrm{Al} & 0.036 & \mathrm{Se} & <0.3 \\ \mathrm{Si} & \mathrm{Matriz} & \mathrm{Zr} & <0.05 \\ \mathrm{P} & 15 & \mathrm{Nb} & <0.05 \\ \mathrm{~S} & 0.036 & \mathrm{Mo} & <0.05 \\ \mathrm{Cl} & <0.5 & \mathrm{Ag} & <0.2 \\ \mathrm{~K} & 0.16 & \mathrm{Sn} & <0.2 \\ \mathrm{Ca} & <0.1 & \mathrm{Sb} & <0.2 \\ \mathrm{Ti} & <0.001 & \mathrm{~W} & <0.03 \\ \mathrm{~V} & 0.002 & \mathrm{~Pb} & <0.05 \\ \mathrm{Cr} & 0.012 & \mathrm{Bi} & <0.03 \\ \mathrm{Mn} & <0.005 & \mathrm{Th} & <0.01 \\ \mathrm{Fe} & 0.47 & \mathrm{U} & <0.01\end{array}$


Tabela 22 - Resultados da análise por GDMS da amostra PR - 10/5.

$\begin{array}{cccc}\text { Elemento } & \text { ppmw } & \text { Elemento } & \text { ppmw } \\ \mathrm{Li} & <0.05 & \mathrm{Co} & <0.01 \\ \mathrm{Be} & <0.05 & \mathrm{Ni} & 0.030 \\ \mathrm{~B} & 4.4 & \mathrm{Cu} & <0.05 \\ \mathrm{~F} & <0.3 & \mathrm{Zn} & <0.05 \\ \mathrm{Na} & 0.15 & \mathrm{Ge} & <0.5 \\ \mathrm{Mg} & <0.01 & \mathrm{As} & <0.05 \\ \mathrm{Al} & 0.058 & \mathrm{Se} & <0.3 \\ \mathrm{Si} & \mathrm{Matriz} & \mathrm{Zr} & <0.05 \\ \mathrm{P} & 22 & \mathrm{Nb} & <0.05 \\ \mathrm{~S} & 0.049 & \mathrm{Mo} & <0.05 \\ \mathrm{Cl} & <0.5 & \mathrm{Ag} & <0.2 \\ \mathrm{~K} & 0.15 & \mathrm{Sn} & <0.2 \\ \mathrm{Ca} & <0.1 & \mathrm{Sb} & <0.2 \\ \mathrm{Ti} & 0.001 & \mathrm{~W} & <0.03 \\ \mathrm{~V} & <0.001 & \mathrm{~Pb} & <0.05 \\ \mathrm{Cr} & 0.010 & \mathrm{Bi} & <0.03 \\ \mathrm{Mn} & <0.005 & \mathrm{Th} & <0.01 \\ \mathrm{Fe} & 0.92 & \mathrm{U} & <0.01\end{array}$

Tabela 23 - Resultados da análise por GDMS da amostra PR - 10/8.

$\begin{array}{cccc}\text { Elemento } & \text { ppmw } & \text { Elemento } & \text { ppmw } \\ \mathrm{Li} & <0.05 & \mathrm{Co} & <0.01 \\ \mathrm{Be} & <0.05 & \mathrm{Ni} & 0.030 \\ \mathrm{~B} & 5.1 & \mathrm{Cu} & <0.05 \\ \mathrm{~F} & <0.3 & \mathrm{Zn} & <0.05 \\ \mathrm{Na} & 0.27 & \mathrm{Ge} & <0.5 \\ \mathrm{Mg} & 0.016 & \mathrm{As} & <0.05 \\ \mathrm{Al} & 0.080 & \mathrm{Se} & <0.3 \\ \mathrm{Si} & \mathrm{Matriz} & \mathrm{Zr} & <0.05 \\ \mathrm{P} & 27 & \mathrm{Nb} & <0.05 \\ \mathrm{~S} & 0.032 & \mathrm{Mo} & <0.05 \\ \mathrm{Cl} & <0.5 & \mathrm{Ag} & <0.2 \\ \mathrm{~K} & 0.45 & \mathrm{Sn} & <0.2 \\ \mathrm{Ca} & <0.1 & \mathrm{Sb} & <0.2 \\ \mathrm{Ti} & <0.001 & \mathrm{~W} & <0.03 \\ \mathrm{~V} & <0.001 & \mathrm{~Pb} & <0.05 \\ \mathrm{Cr} & 0.064 & \mathrm{Bi} & <0.03 \\ \mathrm{Mn} & <0.005 & \mathrm{Th} & <0.01 \\ \mathrm{Fe} & 0.060 & \mathrm{U} & <0.01\end{array}$


Tabela 24 - Resultados da análise por GDMS da amostra PR - 20/2.

$\begin{array}{cccc}\text { Elemento } & \text { ppmw } & \text { Elemento } & \text { ppmw } \\ \mathrm{Li} & <0.05 & \mathrm{Co} & <0.01 \\ \mathrm{Be} & <0.05 & \mathrm{Ni} & 0.025 \\ \mathrm{~B} & 2.8 & \mathrm{Cu} & 0.070 \\ \mathrm{~F} & <0.3 & \mathrm{Zn} & <0.05 \\ \mathrm{Na} & 0.046 & \mathrm{Ge} & <0.5 \\ \mathrm{Mg} & <0.01 & \mathrm{As} & <0.05 \\ \mathrm{Al} & 0.084 & \mathrm{Se} & <0.3 \\ \mathrm{Si} & \mathrm{Matriz} & \mathrm{Zr} & <0.05 \\ \mathrm{P} & 12 & \mathrm{Nb} & <0.05 \\ \mathrm{~S} & 0.017 & \mathrm{Mo} & <0.05 \\ \mathrm{Cl} & <0.5 & \mathrm{Ag} & <0.2 \\ \mathrm{~K} & 0.098 & \mathrm{Sn} & <0.2 \\ \mathrm{Ca} & <0.1 & \mathrm{Sb} & <0.2 \\ \mathrm{Ti} & <0.001 & \mathrm{~W} & <0.03 \\ \mathrm{~V} & <0.001 & \mathrm{~Pb} & <0.05 \\ \mathrm{Cr} & 0.015 & \mathrm{Bi} & <0.03 \\ \mathrm{Mn} & <0.005 & \mathrm{Th} & <0.01 \\ \mathrm{Fe} & 0.032 & \mathrm{U} & <0.01\end{array}$

Tabela 25 - Resultados da análise por GDMS da amostra PR - 20/7.

$\begin{array}{cccc}\text { Elemento } & \text { ppmw } & \text { Elemento } & \text { ppmw } \\ \mathrm{Li} & <0.05 & \mathrm{Co} & <0.01 \\ \mathrm{Be} & <0.05 & \mathrm{Ni} & 0.011 \\ \mathrm{~B} & 5.4 & \mathrm{Cu} & 0.070 \\ \mathrm{~F} & <0.3 & \mathrm{Zn} & <0.05 \\ \mathrm{Na} & 0.071 & \mathrm{Ge} & <0.5 \\ \mathrm{Mg} & <0.01 & \mathrm{As} & <0.05 \\ \mathrm{Al} & 0.087 & \mathrm{Se} & <0.3 \\ \mathrm{Si} & \mathrm{Matriz} & \mathrm{Zr} & <0.05 \\ \mathrm{P} & 13 & \mathrm{Nb} & <0.05 \\ \mathrm{~S} & 0.015 & \mathrm{Mo} & <0.05 \\ \mathrm{Cl} & <0.5 & \mathrm{Ag} & <0.2 \\ \mathrm{~K} & 0.13 & \mathrm{Sn} & <0.2 \\ \mathrm{Ca} & <0.1 & \mathrm{Sb} & <0.2 \\ \mathrm{Ti} & <0.001 & \mathrm{~W} & <0.03 \\ \mathrm{~V} & <0.001 & \mathrm{~Pb} & <0.05 \\ \mathrm{Cr} & 0.018 & \mathrm{Bi} & <0.03 \\ \mathrm{Mn} & <0.005 & \mathrm{Th} & <0.01 \\ \mathrm{Fe} & 0.10 & \mathrm{U} & <0.01\end{array}$


Tabela 26 - Resultados da análise por GDMS da amostra PR - 110/2.

$\begin{array}{cccc}\text { Elemento } & \text { ppmw } & \text { Elemento } & \text { ppmw } \\ \mathrm{Li} & <0.05 & \mathrm{Co} & <0.01 \\ \mathrm{Be} & <0.05 & \mathrm{Ni} & 0.026 \\ \mathrm{~B} & 2.8 & \mathrm{Cu} & 0.10 \\ \mathrm{~F} & <0.3 & \mathrm{Zn} & <0.05 \\ \mathrm{Na} & 0.061 & \mathrm{Ge} & <0.5 \\ \mathrm{Mg} & <0.01 & \mathrm{As} & <0.05 \\ \mathrm{Al} & 0.070 & \mathrm{Se} & <0.3 \\ \mathrm{Si} & \mathrm{Matriz} & \mathrm{Zr} & <0.05 \\ \mathrm{P} & 18 & \mathrm{Nb} & <0.05 \\ \mathrm{~S} & 0.028 & \mathrm{Mo} & <0.05 \\ \mathrm{Cl} & <0.5 & \mathrm{Ag} & <0.2 \\ \mathrm{~K} & 0.19 & \mathrm{Sn} & <0.2 \\ \mathrm{Ca} & <0.1 & \mathrm{Sb} & <0.2 \\ \mathrm{Ti} & <0.001 & \mathrm{~W} & <0.03 \\ \mathrm{~V} & <0.001 & \mathrm{~Pb} & <0.05 \\ \mathrm{Cr} & 0.010 & \mathrm{Bi} & <0.03 \\ \mathrm{Mn} & <0.005 & \mathrm{Th} & <0.01 \\ \mathrm{Fe} & 0.18 & \mathrm{U} & <0.01\end{array}$

Tabela 27 - Resultados da análise por GDMS da amostra PR - 110/7.

$\begin{array}{cccc}\text { Elemento } & \text { ppmw } & \text { Elemento } & \text { ppmw } \\ \mathrm{Li} & <0.05 & \mathrm{Co} & <0.01 \\ \mathrm{Be} & <0.05 & \mathrm{Ni} & 0.030 \\ \mathrm{~B} & 5.1 & \mathrm{Cu} & 0.062 \\ \mathrm{~F} & <0.3 & \mathrm{Zn} & <0.05 \\ \mathrm{Na} & 0.098 & \mathrm{Ge} & <0.5 \\ \mathrm{Mg} & <0.01 & \mathrm{As} & <0.05 \\ \mathrm{Al} & 0.11 & \mathrm{Se} & <0.3 \\ \mathrm{Si} & \mathrm{Matriz} & \mathrm{Zr} & <0.05 \\ \mathrm{P} & 22 & \mathrm{Nb} & <0.05 \\ \mathrm{~S} & 0.041 & \mathrm{Mo} & <0.05 \\ \mathrm{Cl} & <0.5 & \mathrm{Ag} & <0.2 \\ \mathrm{~K} & 0.069 & \mathrm{Sn} & <0.2 \\ \mathrm{Ca} & <0.1 & \mathrm{Sb} & <0.2 \\ \mathrm{Ti} & 0.002 & \mathrm{~W} & <0.03 \\ \mathrm{~V} & 0.001 & \mathrm{~Pb} & <0.05 \\ \mathrm{Cr} & 0.010 & \mathrm{Bi} & <0.03 \\ \mathrm{Mn} & 0.007 & \mathrm{Th} & <0.01 \\ \mathrm{Fe} & 0.090 & \mathrm{U} & <0.01\end{array}$




\subsection{Macro e Micrografias}

Neste subitem serão apresentadas nas Figuras 33 a 54 as macro e micrografias dos lingotes GM-05, GM-10, GM-20, GM-110, PR-05, PR-10, PR-20, PR-110 e a macrografia referente ao lingote EP-08. Em diversos lingotes, não foi possível obter a macroestrutura completa, pois algumas de suas partes fraturaram em pequenos pedaços, impossibilitando a obtenção da macroestrutura na região. 


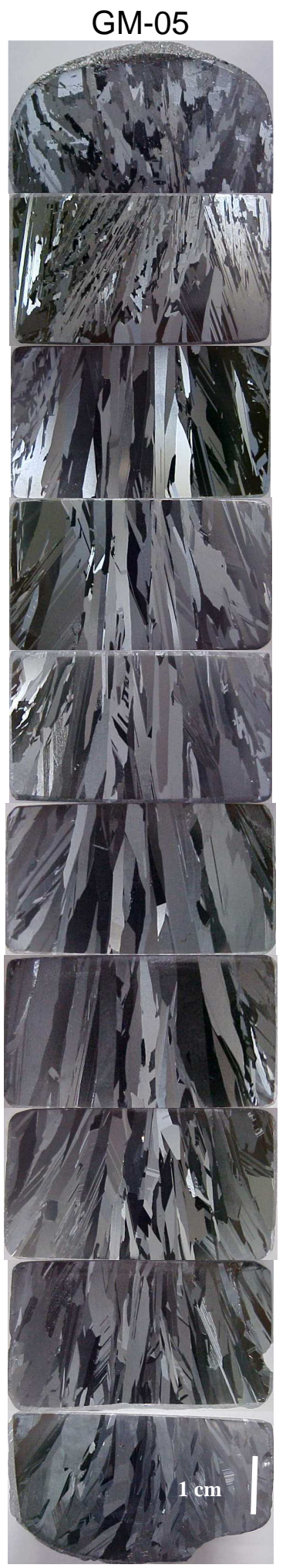

Figura 33 -

Macrografia do lingote GM-05
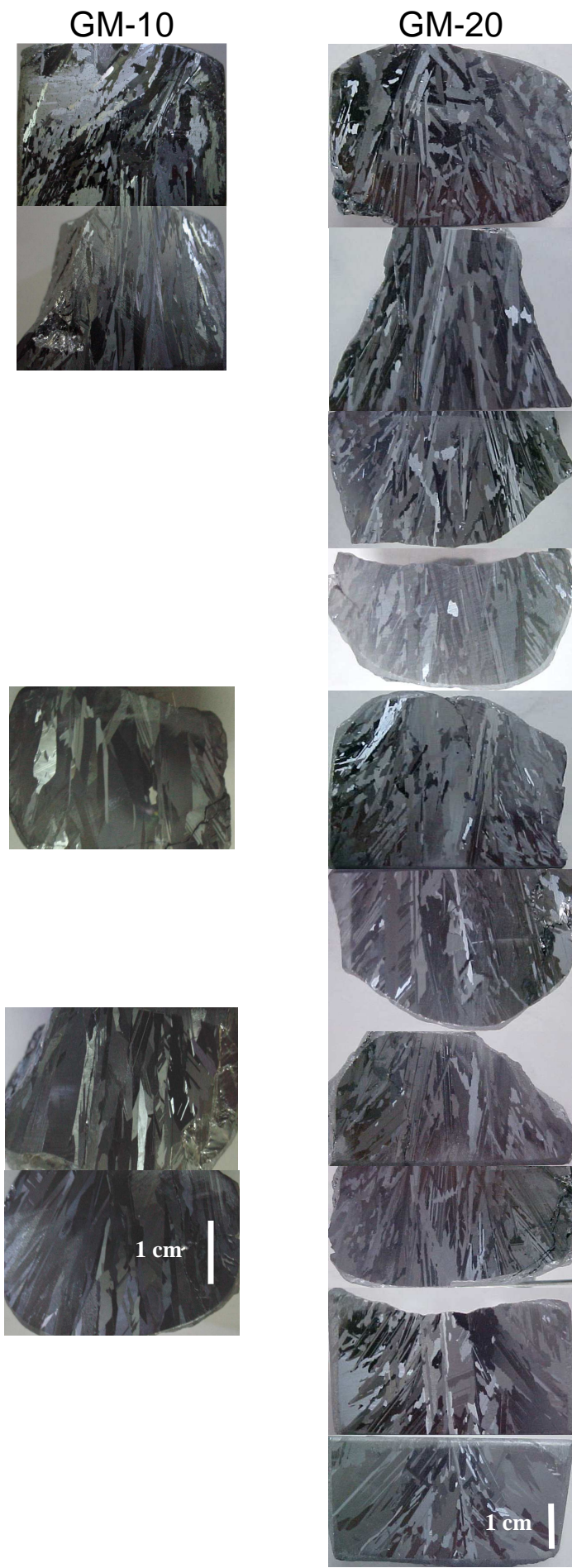

Figura 35 - Macrografia do lingote GM-20

Figura 34 Macrografia do lingote GM-10
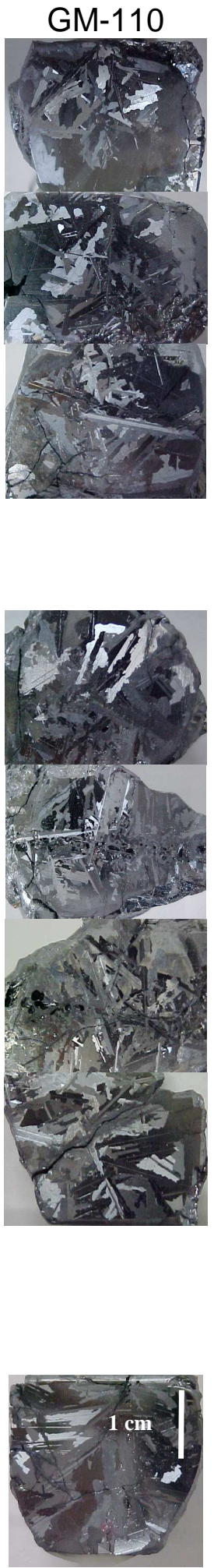

Figura 36 - Macrografia do lingote GM-110 


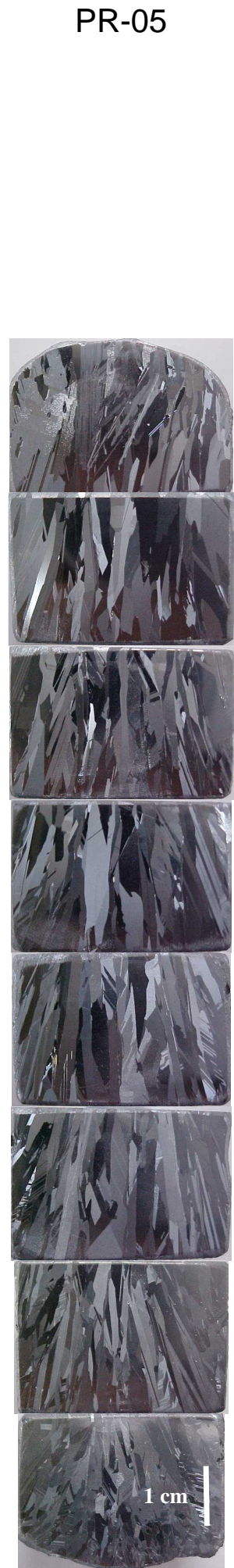

Figura 37 -

Macrografia do lingote PR-05
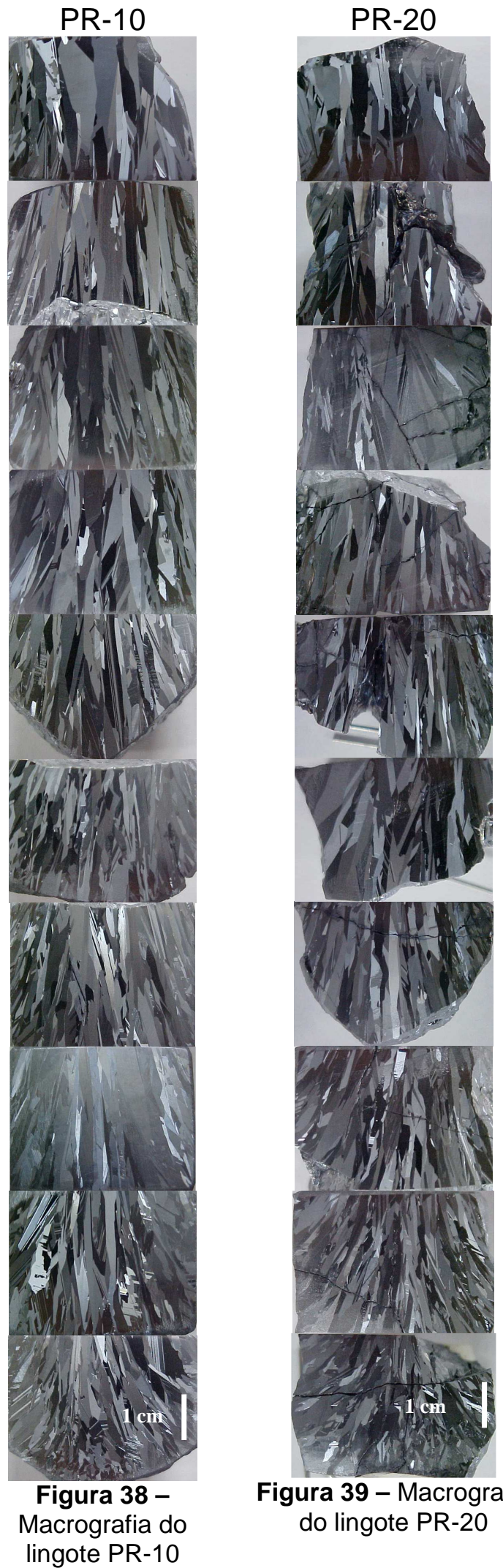

Figura 39 - Macrografia do lingote PR-20
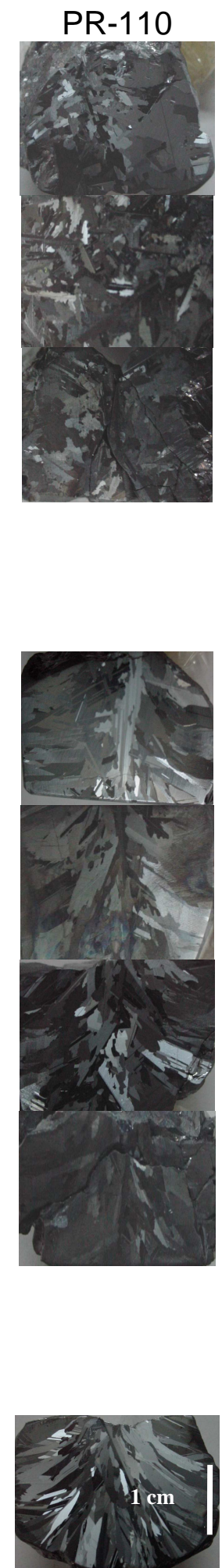

Figura 40 - Macrografia do lingote PR-110 


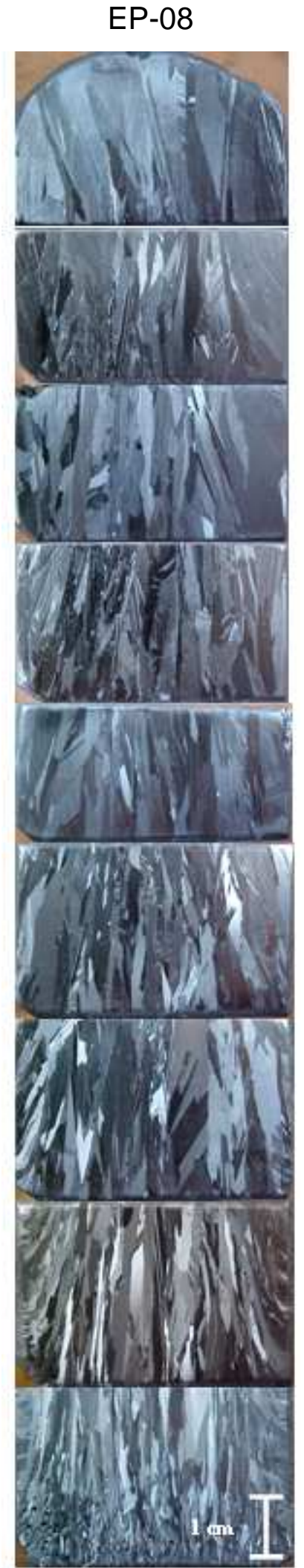

Figura 41 - Macrografia do lingote EP-08 


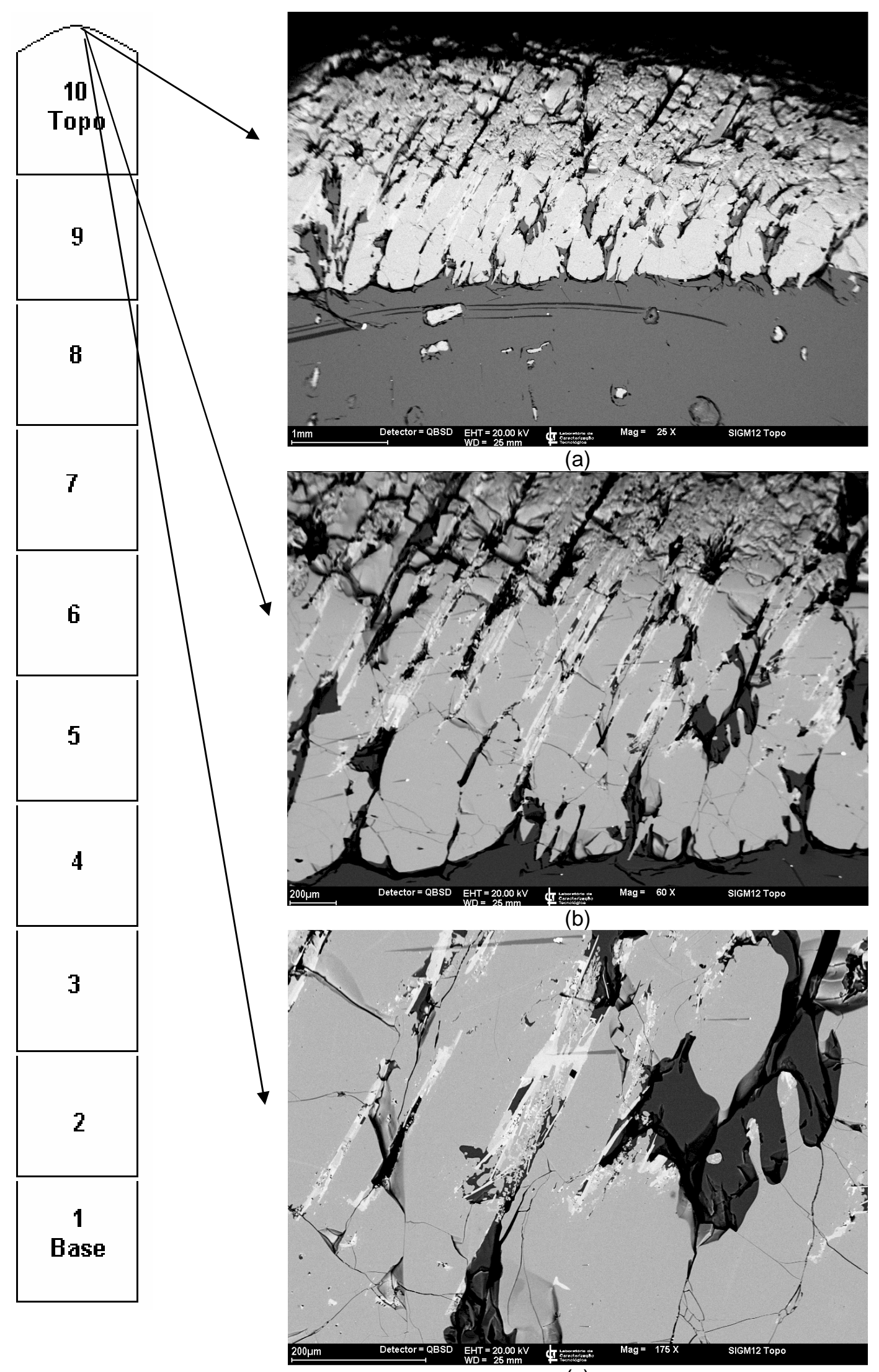

(c)

Figura 42 - Micrografia obtida em microscópio eletrônico de varredura (MEV) em contraste de elétrons retroespalhados do topo do lingote GM-05:(a) camada de intermetálicos; (b) interior da camada de intermetálicos; (c) detalhe dos intermetálicos. 


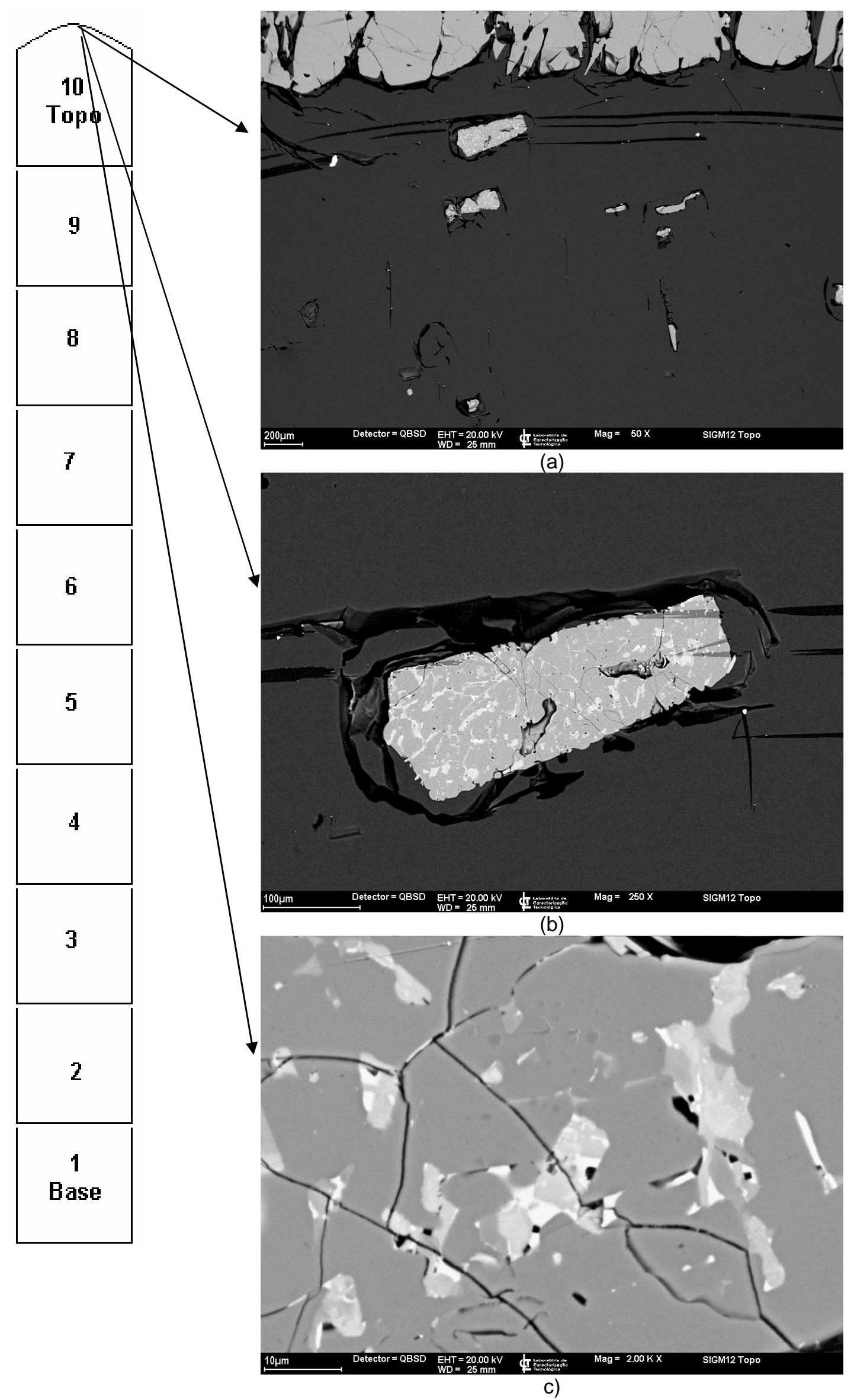

Figura 43 - Micrografia obtida em microscópio eletrônico de varredura (MEV) em contraste de elétrons retroespalhados do topo do lingote GM-05 (SiGM; $5 \mu \mathrm{m} / \mathrm{s}$ ) 


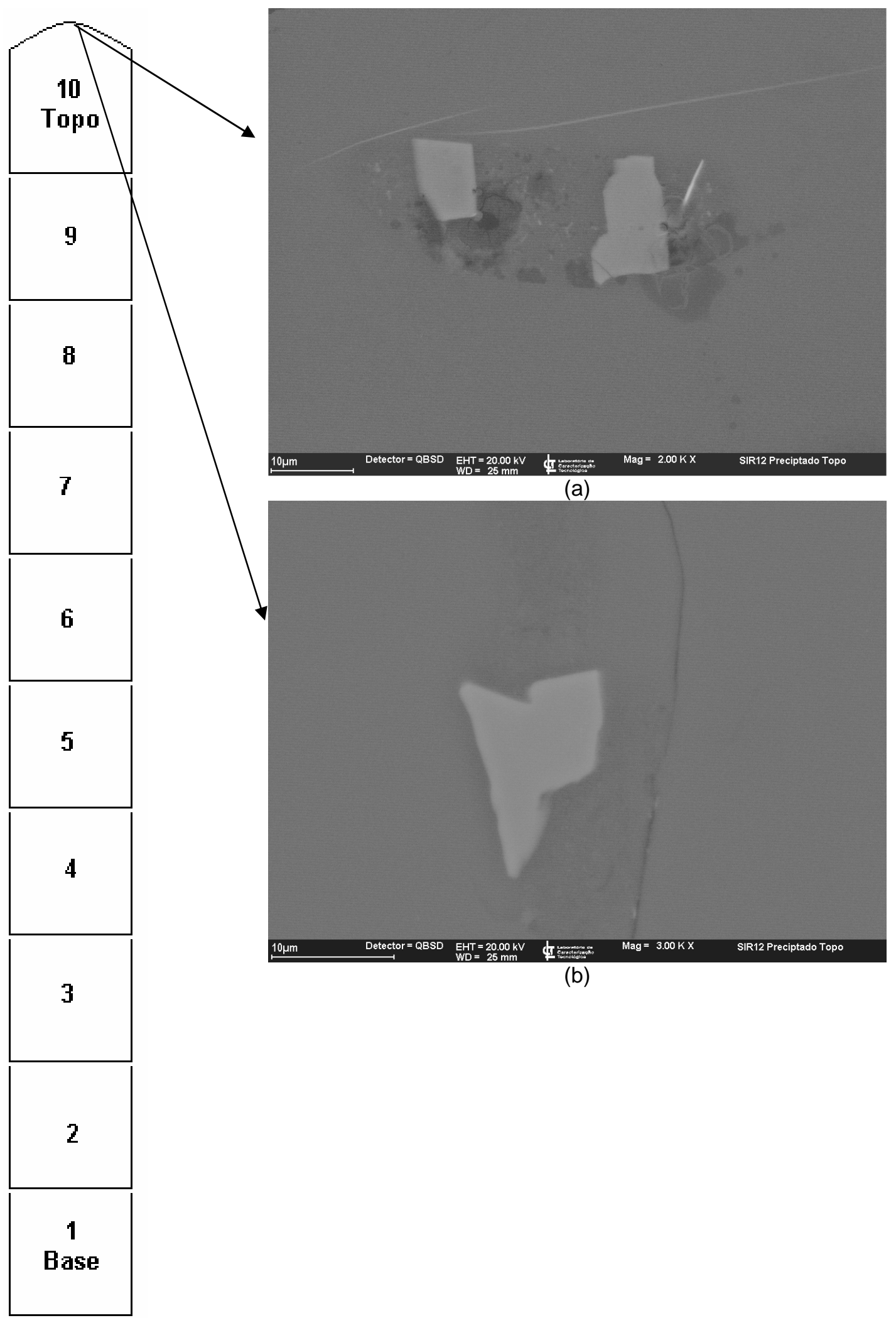

Figura 44 - Micrografia obtida em microscópio eletrônico de varredura (MEV) em contraste de elétrons retroespalhados do topo do lingote PR-05 (SiR; $5 \mu \mathrm{m} / \mathrm{s})$ 


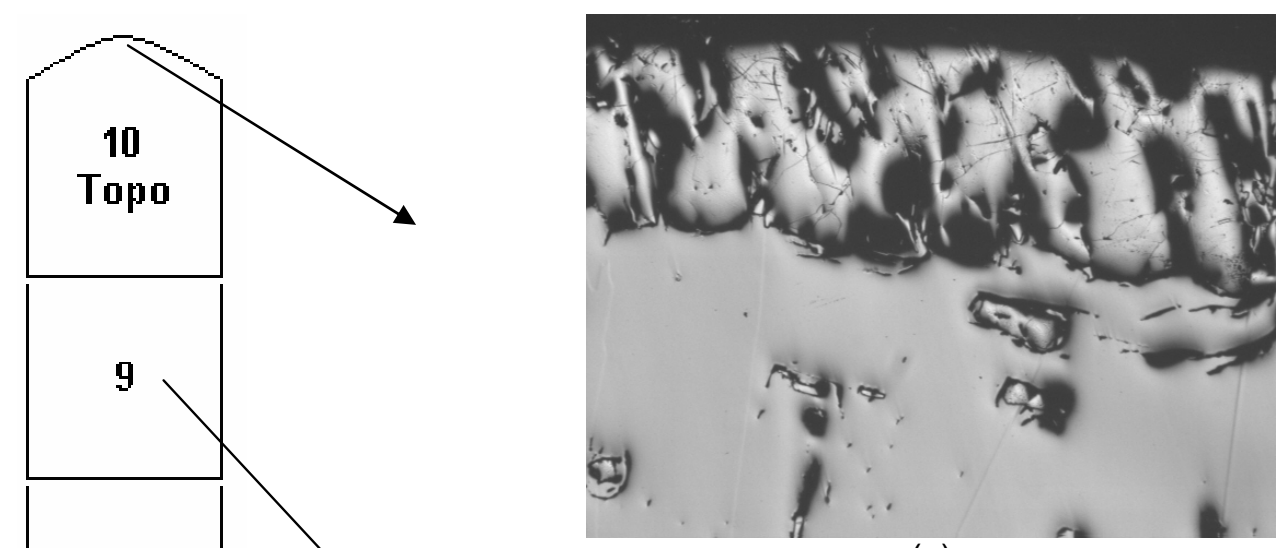

(a)
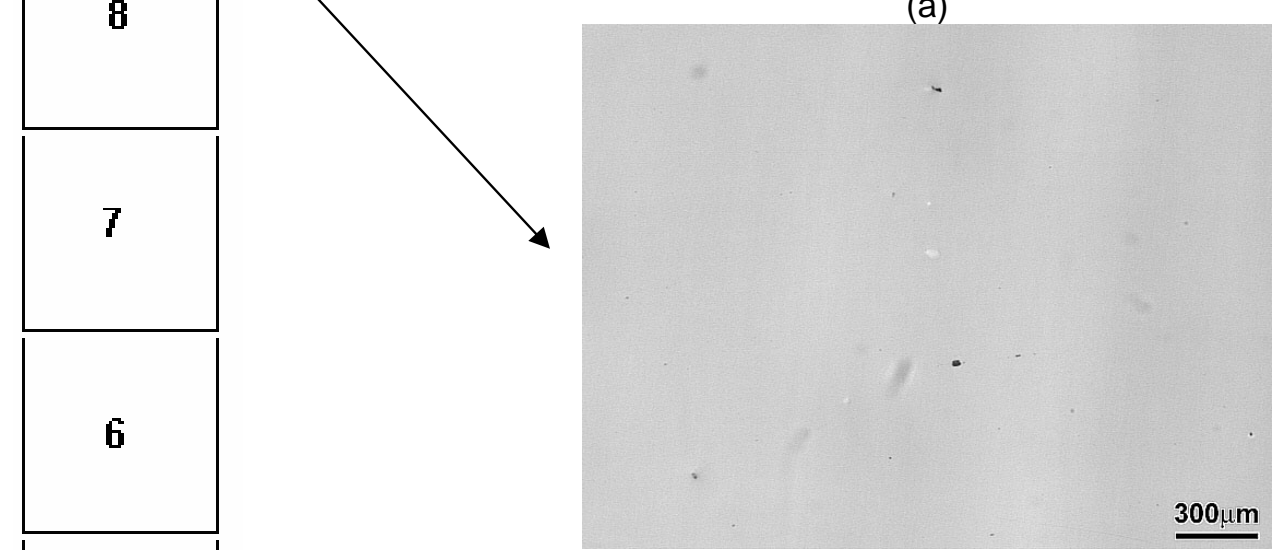

(b)

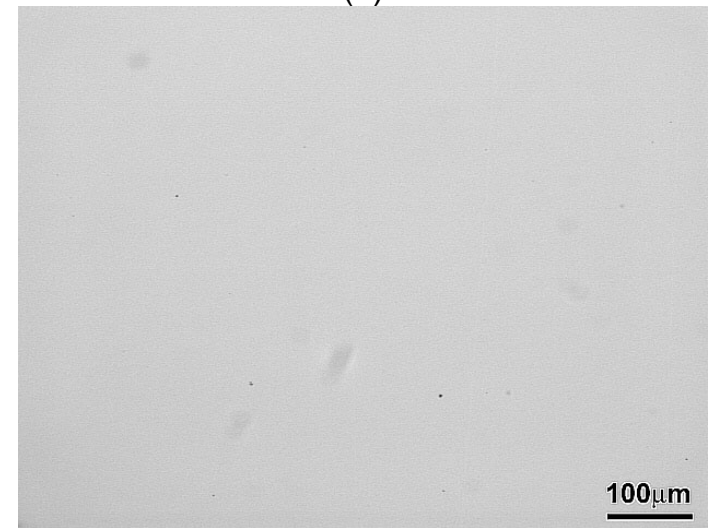

(c)

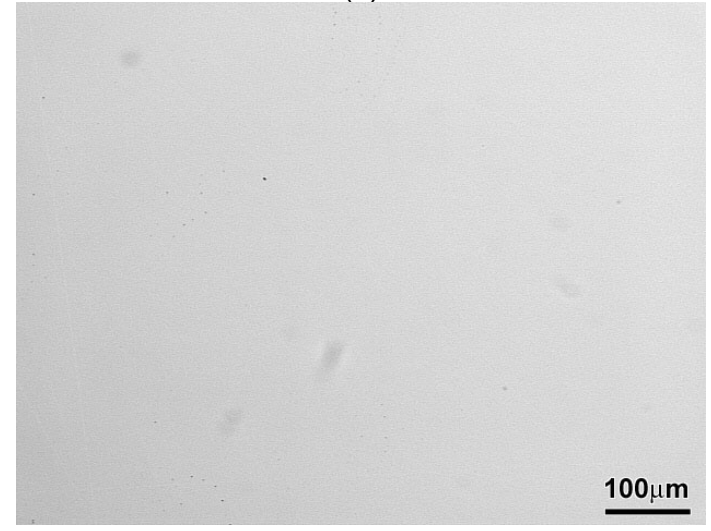

(d)

Figura 45 - Microscopia óptica do lingote GM-05 (SiGM; 5 um/s): (a) topo, (c) centro e (d) base 


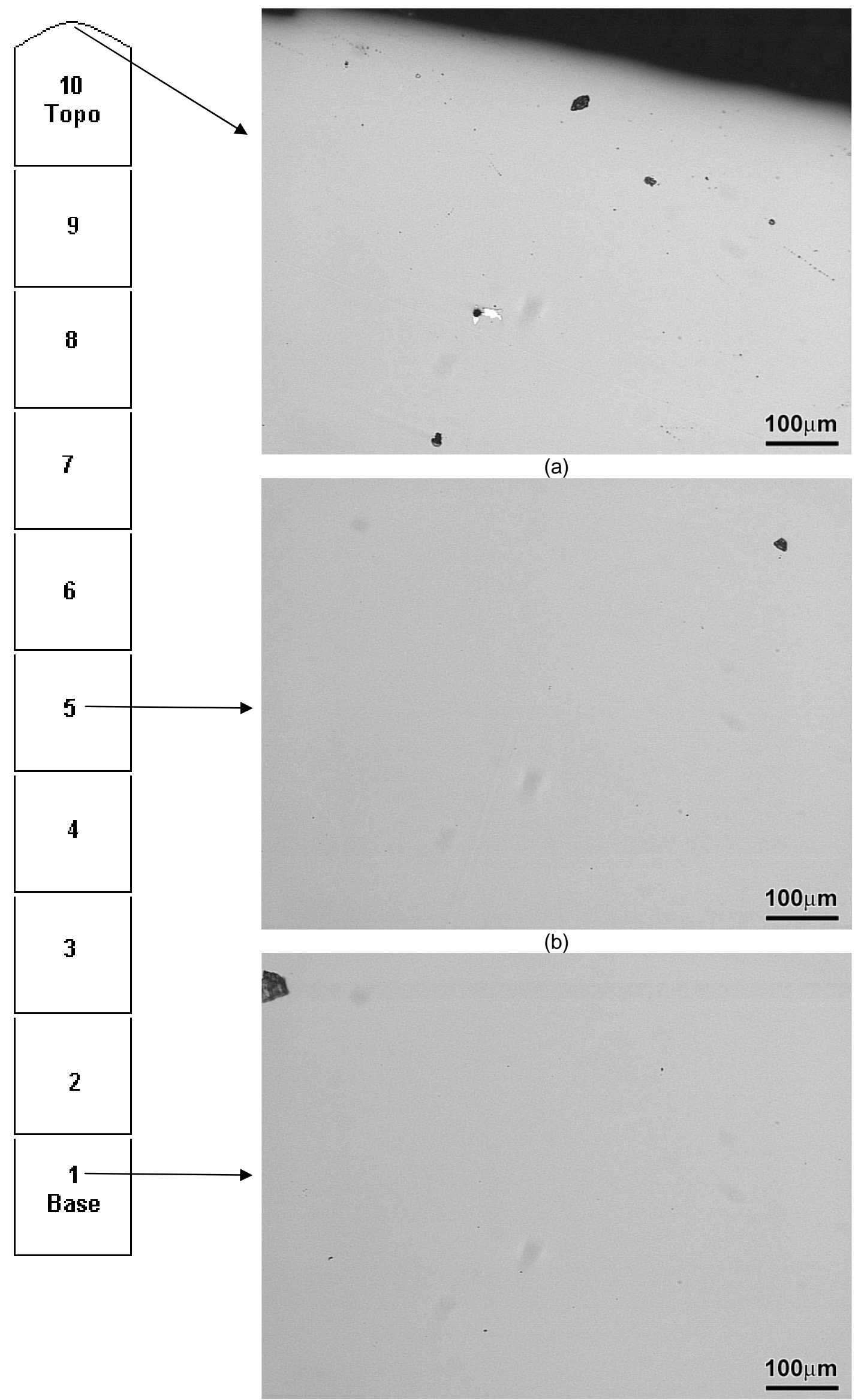

(c)

Figura 46 - Microscopia óptica do lingote PR-05 (SiR; $5 \mu \mathrm{m} / \mathrm{s}$ ): (a) topo, (b) centro e (c) base 


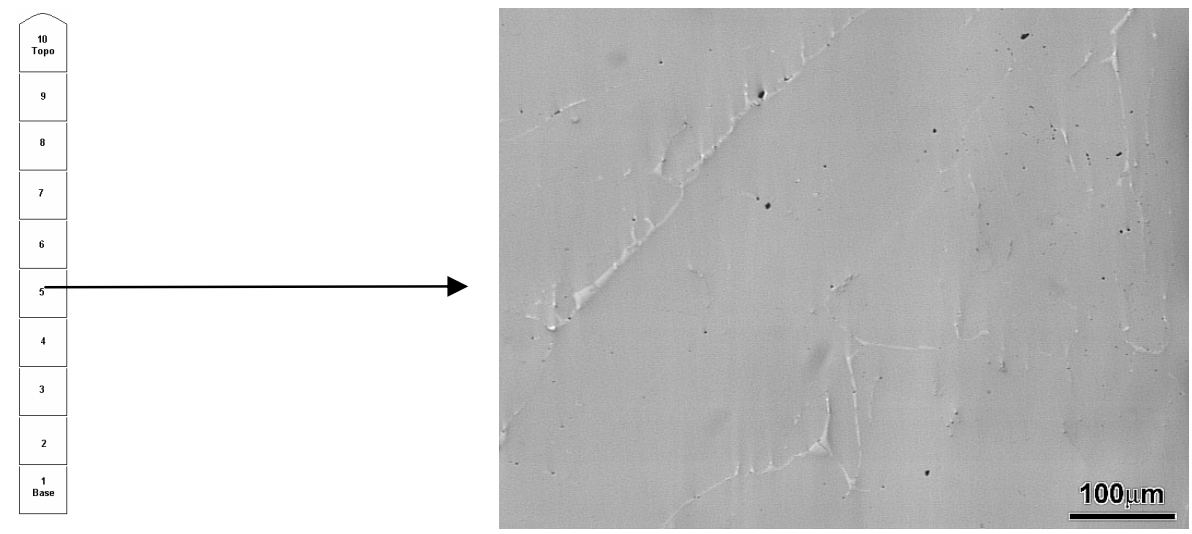

Figura 47 - Microscopia óptica do centro do lingote GM-110 (SiGM 110 $\mu \mathrm{m} / \mathrm{s}$ )
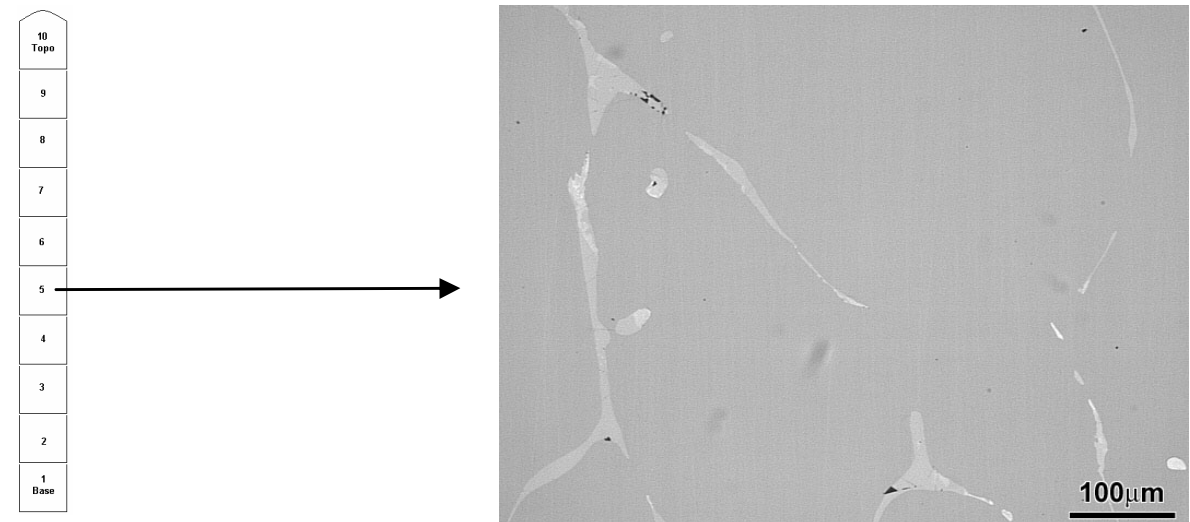

Figura 48 - Microscopia óptica do centro do lingote GM-110 (SiGM 110 $\mu \mathrm{m} / \mathrm{s}$ )

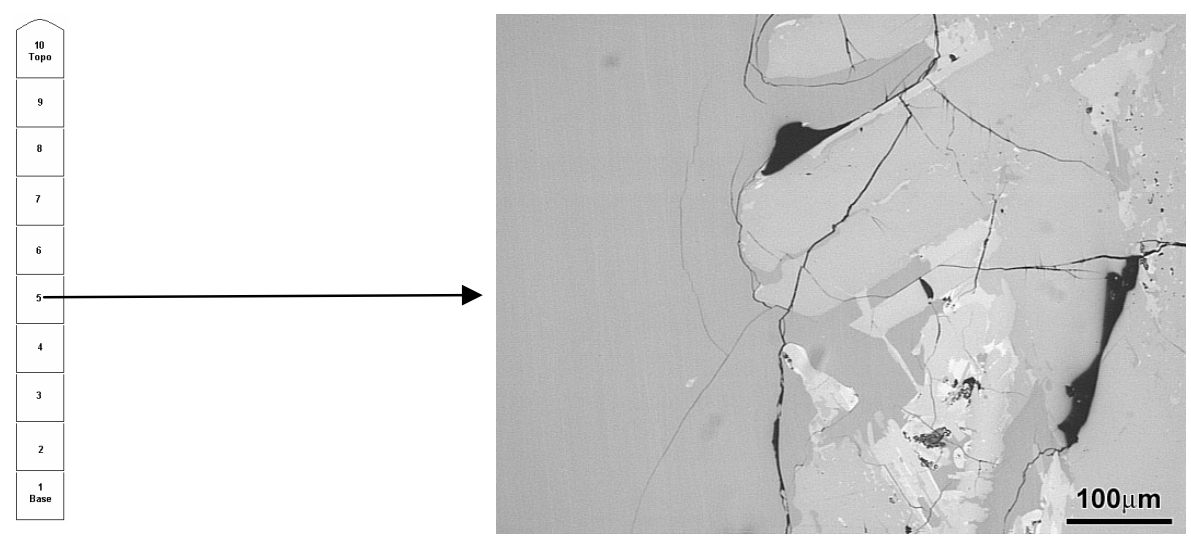

Figura 49 - Microscopia óptica do centro do lingote GM-110 (SiGM 110 $\mu \mathrm{m} / \mathrm{s}$ )
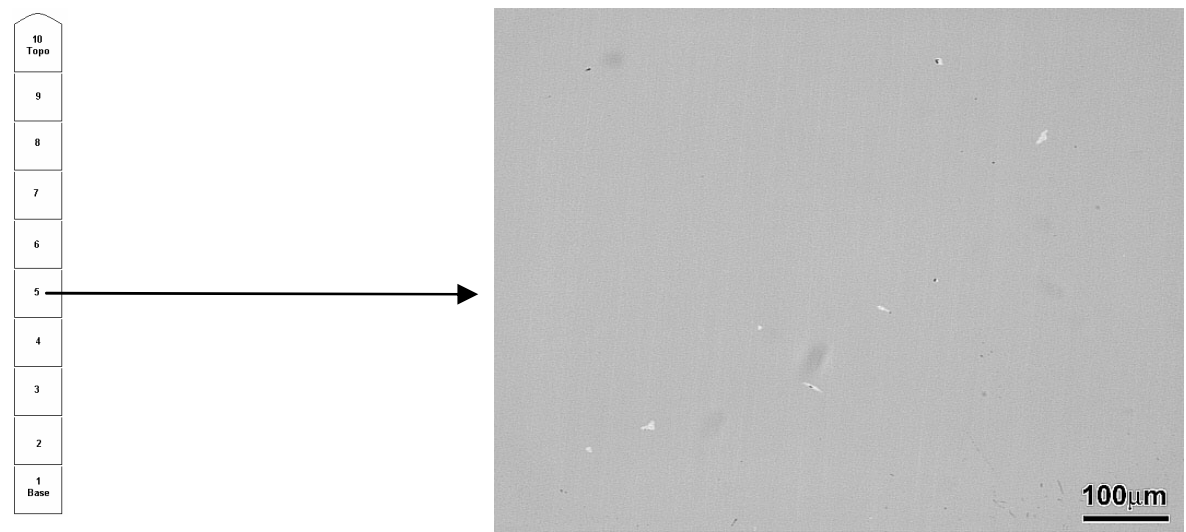

Figura 50 - Microscopia óptica do centro do lingote PR-110 (SiR 110 $\mu \mathrm{m} / \mathrm{s})$ 


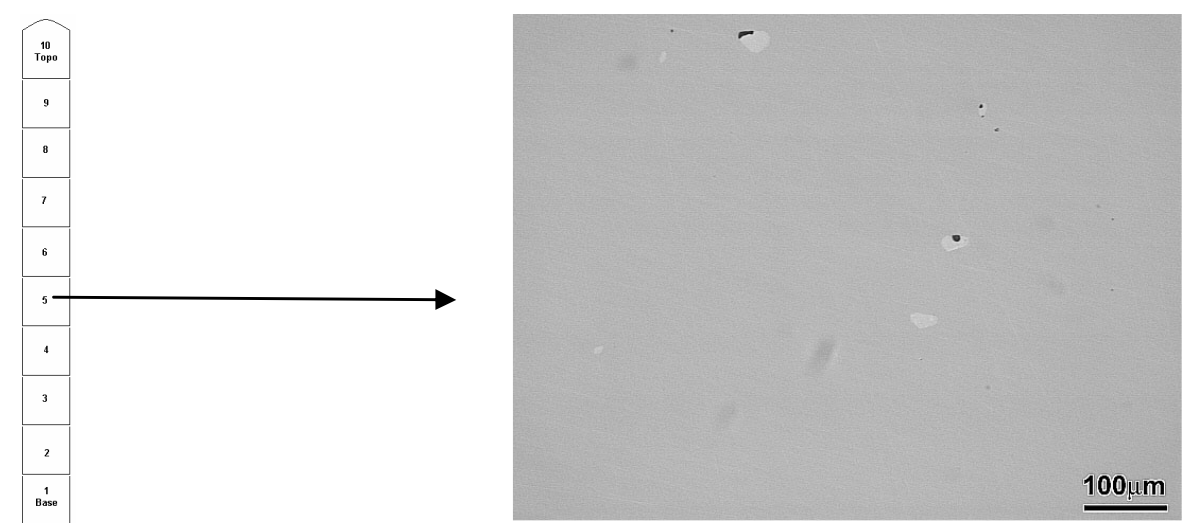

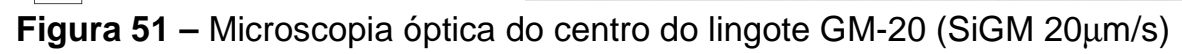

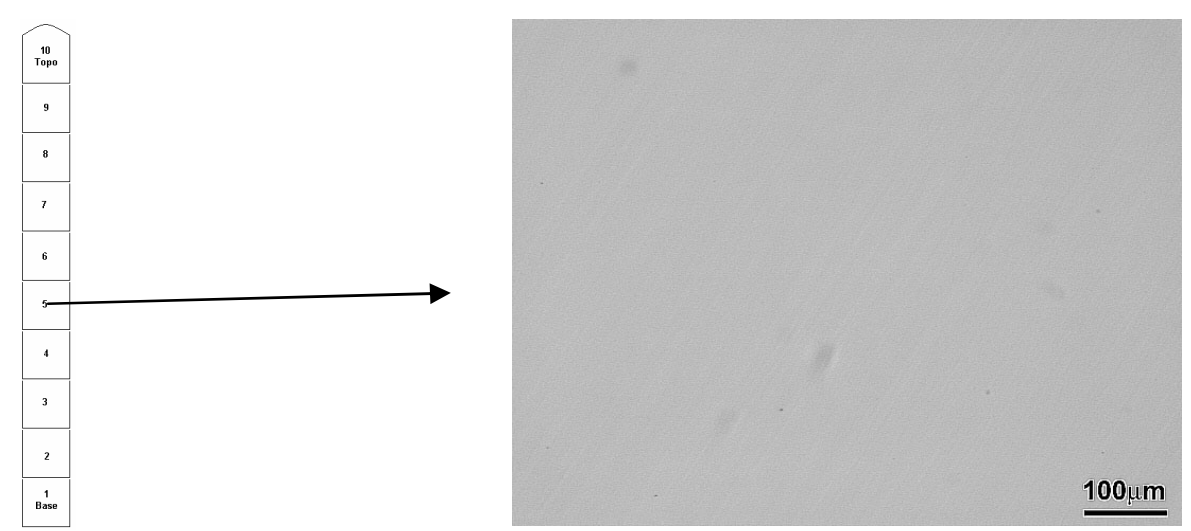

Figura 52 - Microscopia óptica do centro do lingote PR-20 (SiR 20 $\mu \mathrm{m} / \mathrm{s}$ )
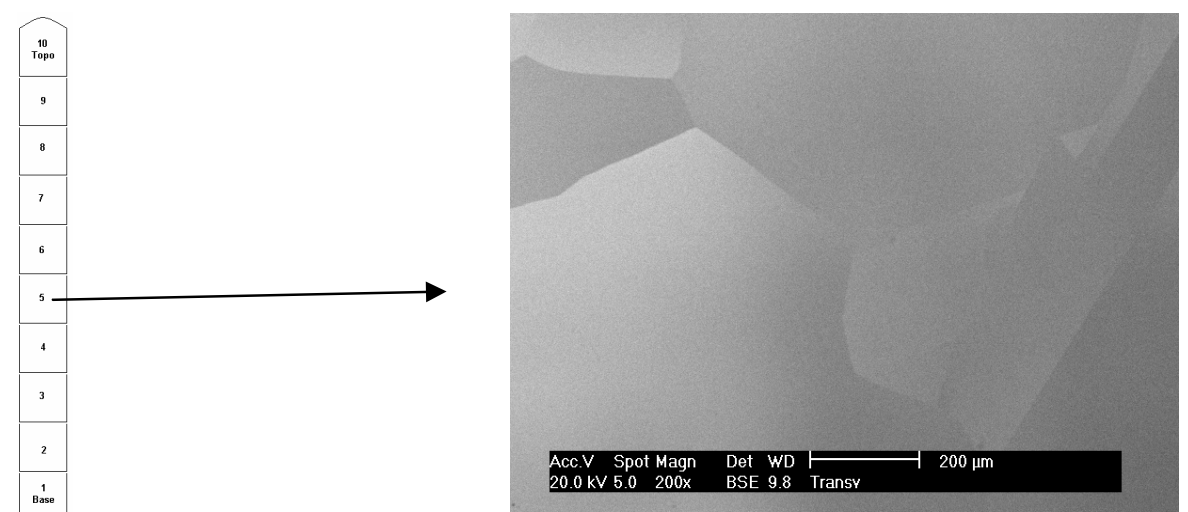

Figura 53 - Micrografia obtida em microscópio eletrônico de varredura (MEV) em contraste de elétrons retroespalhados do centro do lingote Si-3\%Ge (SiGM $5 \mu \mathrm{m} / \mathrm{s}$ ) Seção Transversal
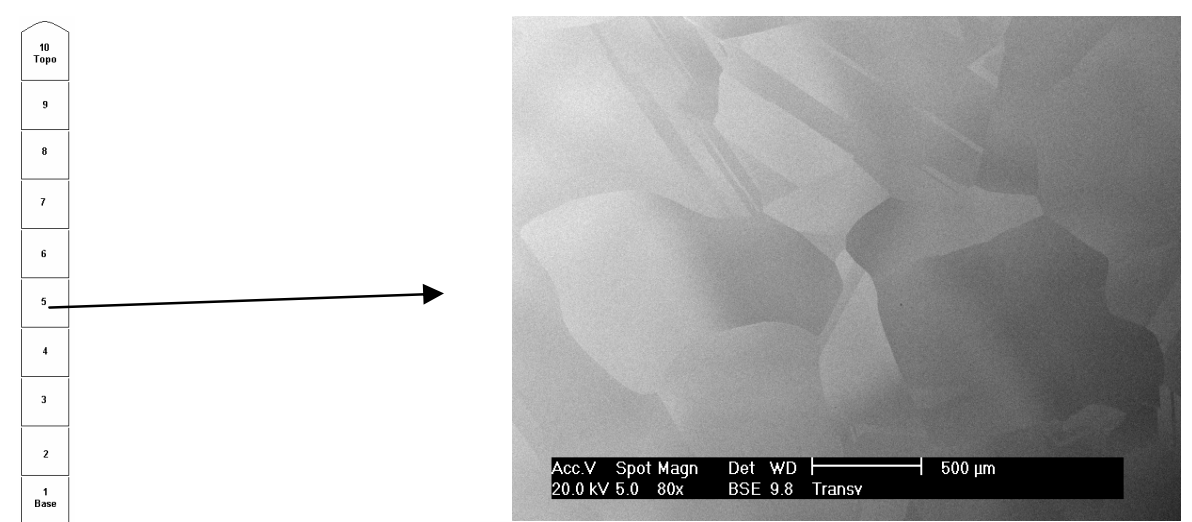

Figura 54 - Micrografia obtida em microscópio eletrônico de varredura (MEV) em contraste de elétrons retroespalhados do centro do lingote Si-3\%Ge (SiGM $5 \mu \mathrm{m} / \mathrm{s})$ Seção Transversal 


\subsection{Análise por Microssonda EDS}

Neste subitem serão apresentados os espectros obtidos a partir da microssonda eletrônica através da análise de espectrometria por dispersão de energia (EDS), descrita no item 4.8.3. A Figura 52 mostra os locais onde foram obtidos os espectros.

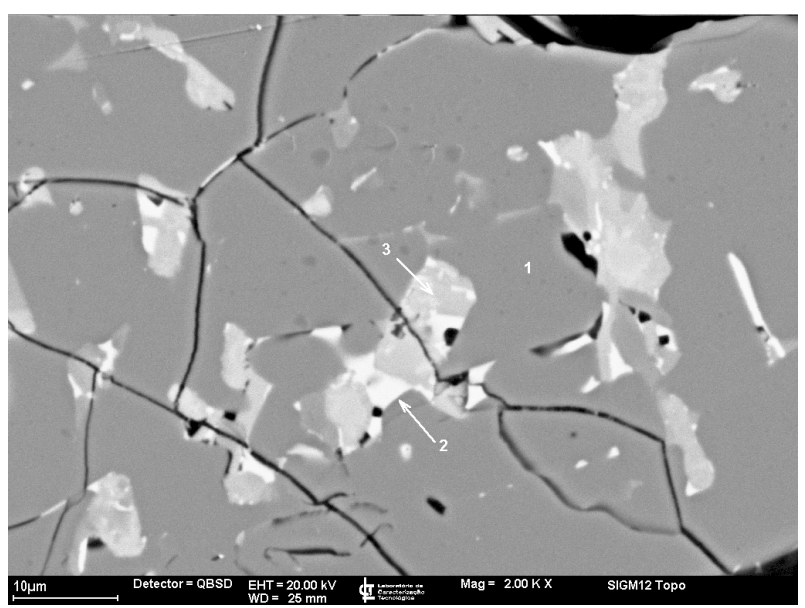

Figura 55 - Micrografia obtida em microscópio eletrônico de varredura (MEV) em contraste de elétrons retroespalhados do topo do lingote GM-05 indicando três pontos onde foram realizadas análises por microssonda (EDS)

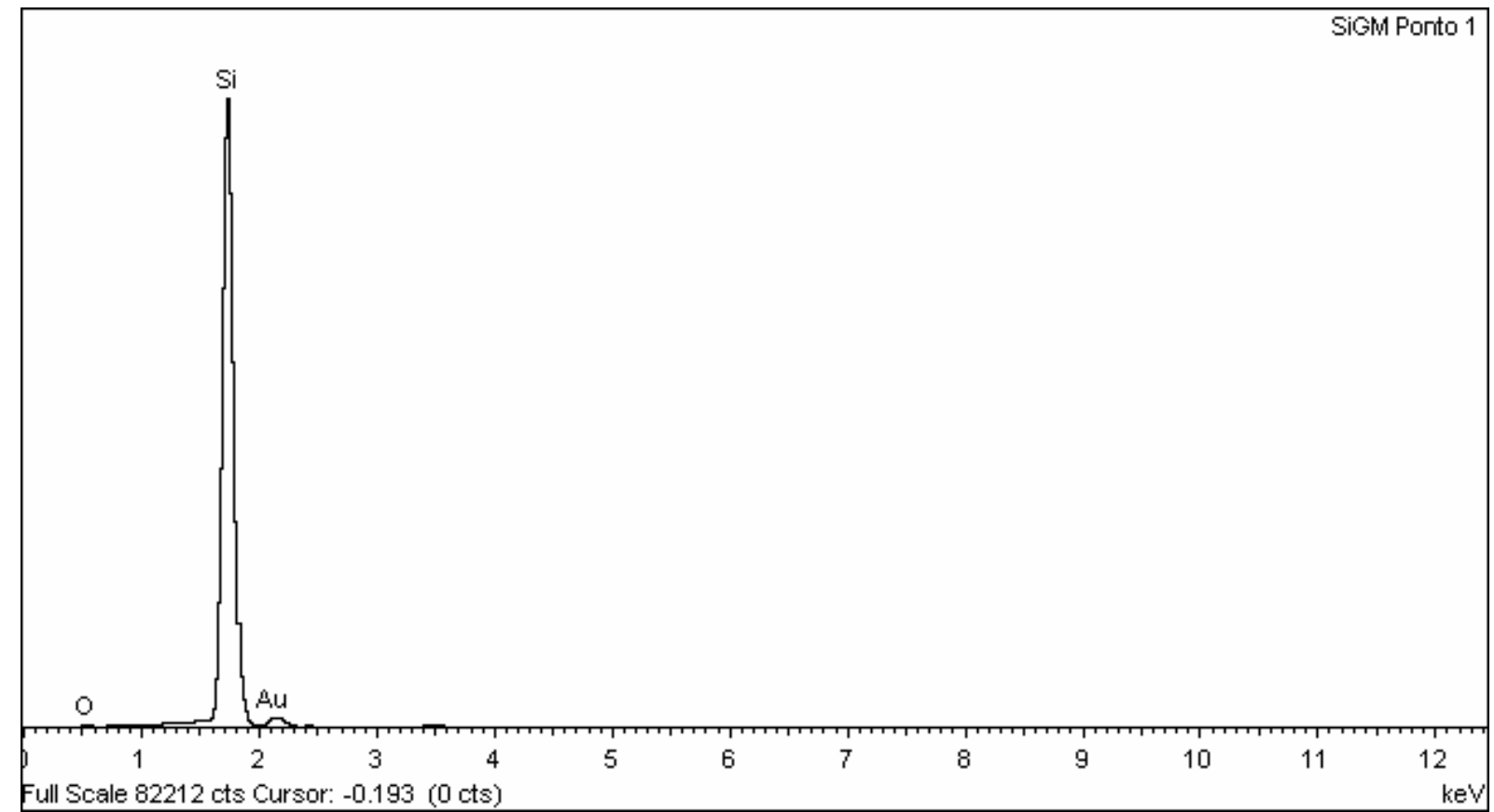

Figura 56 - Espectro obtido por microssonda (EDS) de um intermetálico no topo do lingote GM-05 


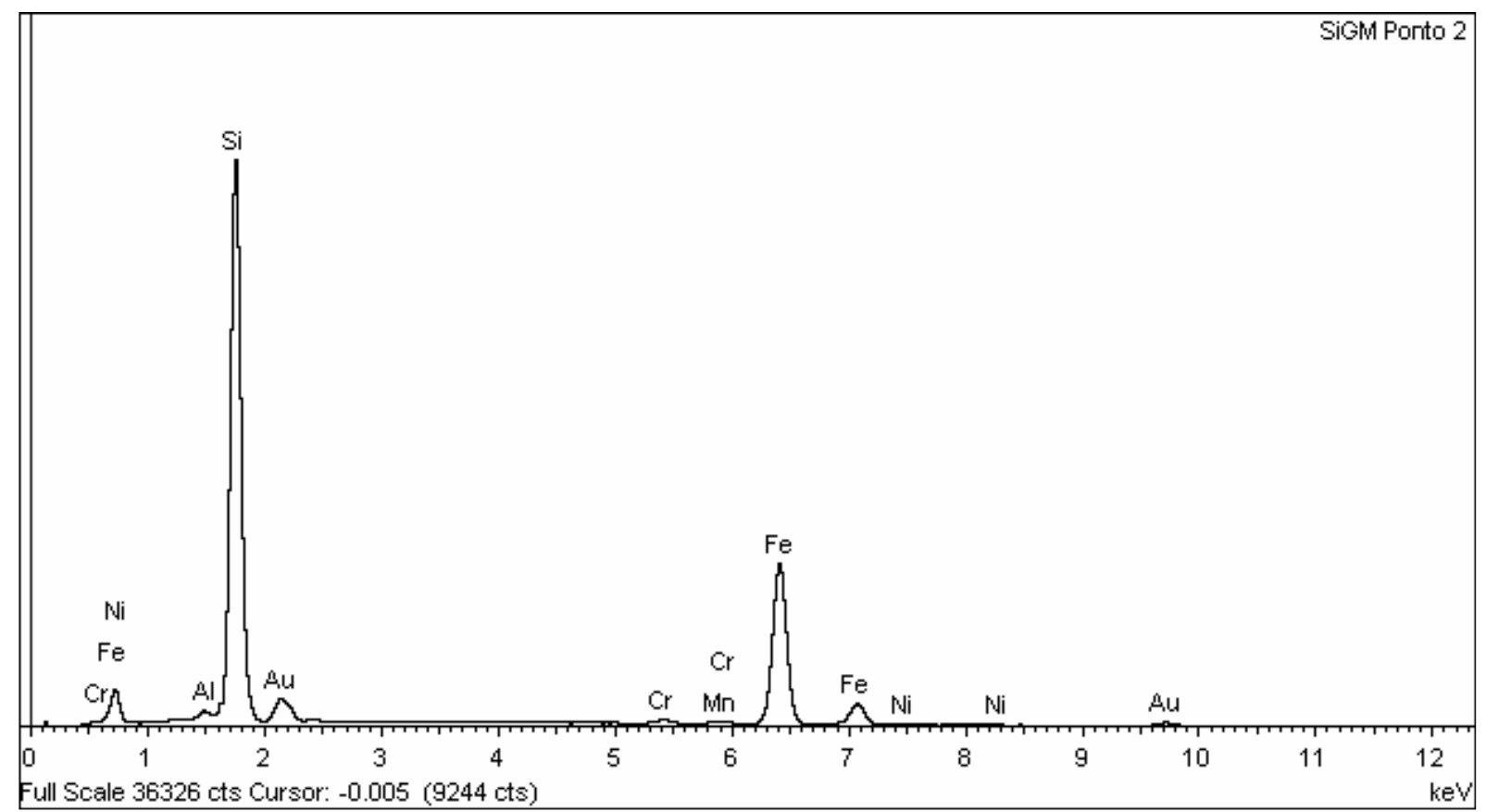

Figura 57 - Espectro obtido por microssonda (EDS) de um intermetálico no topo do lingote GM-05

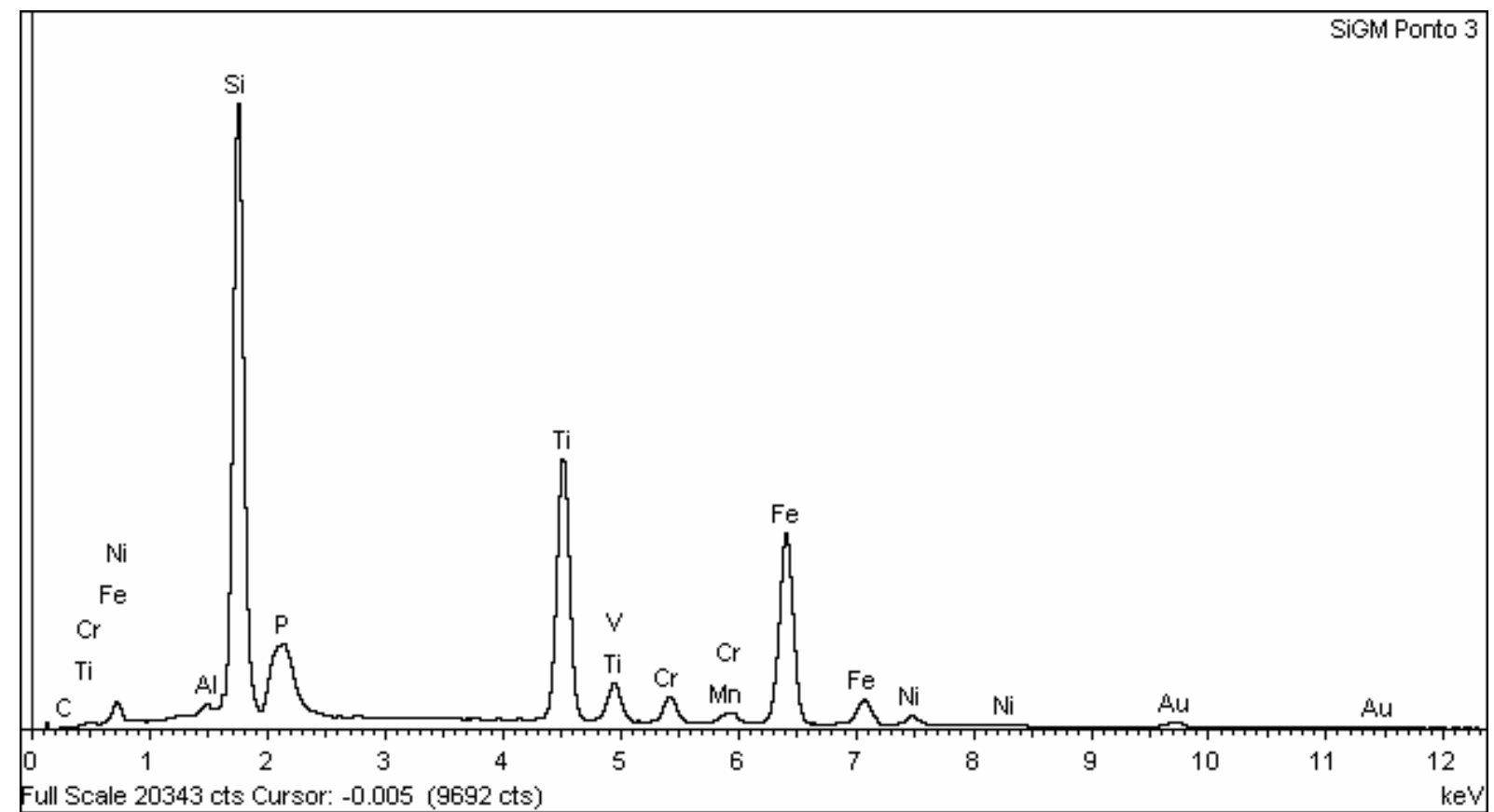

Figura 58 - Espectro obtido por microssonda (EDS) de um intermetálico no topo do lingote GM-05

\subsection{Variação de Temperatura no Líquido e Taxa de Resfriamento}

Neste subitem será apresentada a medida de temperatura no líquido obtida no ensaio onde foram introduzidos dois termopares no interior do molde, em contato com o Si líquido. Na Figura 59 observa-se a variação de temperatura com o tempo desde o momento do vazamento do silício líquido no molde $(t=0)$ até o instante em 
que a extração do molde foi iniciada ( $\mathrm{t}=40 \mathrm{~min})$. Uma estimativa do gradiente térmico no líquido antes do início da extração do molde da zona quente para a zona fria foi obtida a partir das medidas de temperatura através de $G=\left(T_{2}-T_{1}\right) / \Delta z$, onde T1 e T2 estão mostradas na Figura 59 e $\Delta z=5 \mathrm{~cm}$ é a distância entre os dois termopares.

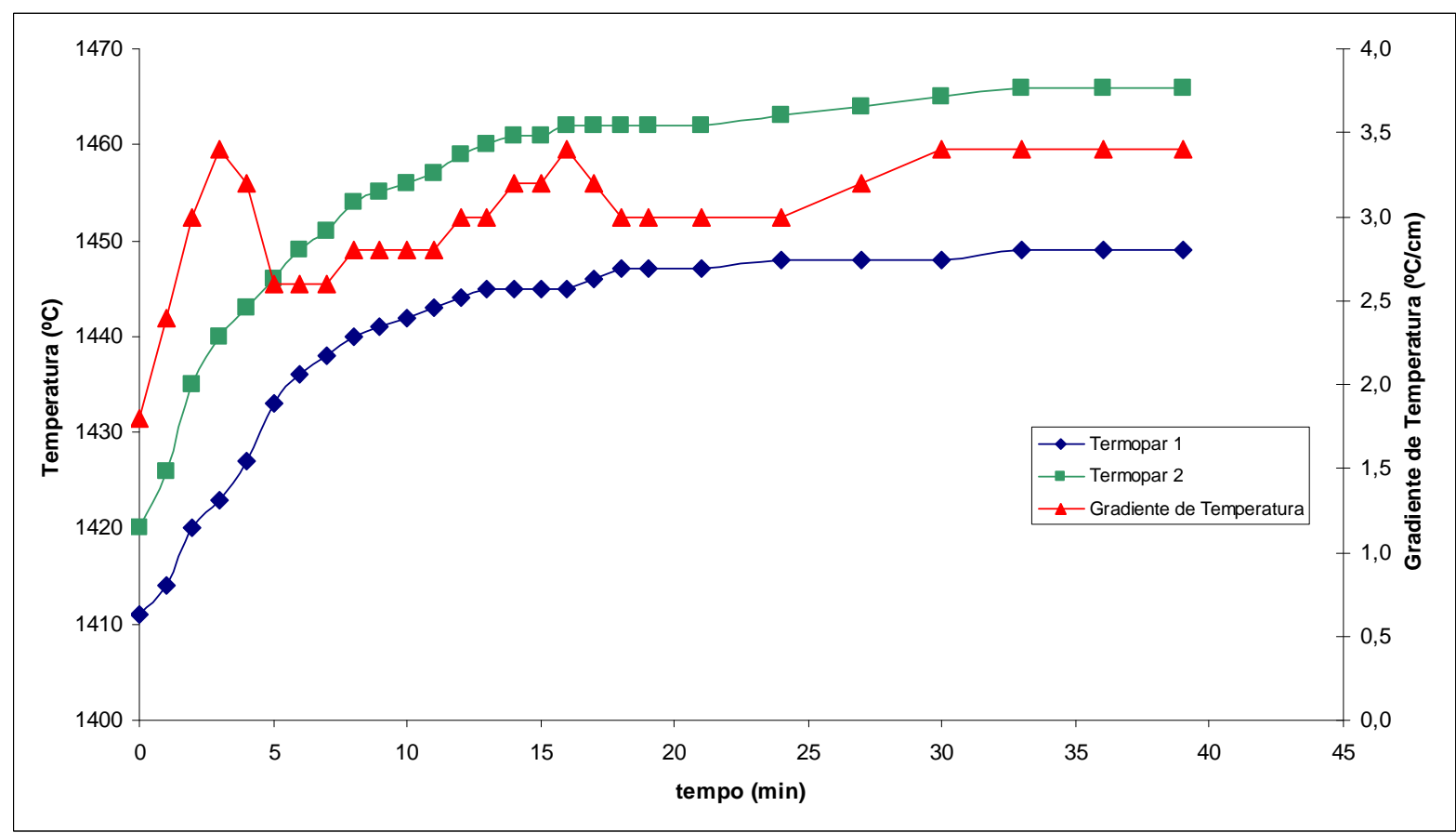

Figura 59 - Variação de temperatura no líquido antes da extração do molde da zona quente para a zona fria da câmara de solidificação. 
CAPÍTULO 6 DISCUSSÃO 


\subsection{DISCUSSÃO}

\subsection{Considerações Iniciais}

Os resultados apresentados no Capítulo 5 serão discutidos nos próximos subitens. Inicialmente serão feitas algumas considerações importantes para o prosseguimento das discussões.

6.1.1 Considerações Preliminares Sobre os Perfis de Concentração de Elementos

Os perfis de concentração de $\mathrm{B}$, Ca e Zn não serão discutidos nos próximos itens. Decidiu-se eliminar os perfis do $B$ da discussão, por ele ser um elemento volátil que, durante a dissolução das amostras para análise por ICP poderia ter sido parcialmente volatilizado. Os perfis de concentração de $\mathrm{Zn}$ não serão discutidos porque, para a maioria dos lingotes, os valores de concentração estão abaixo do limite de detecção do ICP, impossibilitando a obtenção de conclusões (ver Figura 24a). No entanto, observa-se uma perceptível elevação da concentração de zinco no topo dos lingotes obtidos, indicando um provável efeito de refino da região inferior ao topo.

No caso dos perfis de concentração de $\mathrm{Ca}$, a realização de qualquer análise em relação ao refino por solidificação direcional é prejudicada, porque existem outros mecanismos de refino ocorrendo simultaneamente. A remoção de $\mathrm{Ca}$ em solução no Si líquido pode ocorrer por oxidação e/ou vaporização durante a fusão no cadinho de quartzo ou de grafita, ou no molde de quartzo onde foi realizada a extração. A fonte de oxigênio para oxidação do $\mathrm{Ca}$ foi provavelmente a sílica, presente no silício na forma de inclusões, na forma de uma camada de $\mathrm{SiO}_{2}$ passivada na superfície das partículas do SiGM e, principalmente, a sílica do próprio cadinho ou molde onde a extração foi realizada. Esta oxidação retira os elementos de solução através da reação química [FERREIRA NETO, 1991 e 1995] 


$$
\mathrm{SiO}_{2}+\underline{\mathrm{Ca}} \rightarrow 2 \mathrm{CaO}+\mathrm{Si}
$$

Esta reação é possível devido à maior estabilidade termodinâmica do óxido $\mathrm{CaO}$ em relação ao $\mathrm{SiO}_{2}$ e devido ao abaixamento da atividade do mesmo em um sistema $\mathrm{CaO}-\mathrm{SiO}_{2}$ (saturado em $\mathrm{SiO}_{2}$ ), formado na presença de oxidantes $\left(\mathrm{SiO}_{2} \mathrm{e}\right.$ inclusões de escória ricas em $\mathrm{SiO}_{2}$ ).

Além desta reação de oxidação, outro mecanismo de eliminação do $\mathrm{Ca}$ é a sua vaporização através da reação [FERREIRA NETO, 1991 e 1995]:

$$
\underline{\mathrm{Ca}}(\mathrm{I}) \rightarrow \mathrm{Ca}(\mathrm{g})
$$

Ademais, assim como o $\mathrm{Ca}$ reage com inclusões de $\mathrm{SiO}_{2}$ durante a fusão, este elemento, pode também reagir com o tubo de quartzo durante a extração, promovendo um refino adicional que não está necessariamente associado àquele da solidificação direcional [FERREIRA NETO, 1998].

\subsubsection{Análises Químicas por GDMS}

Embora o ICP-AES possua limites de detecção bem próximos aos do GDMS [FAIRES, 1988], as análises realizadas por GDMS forneceram valores de concentração muito abaixo dos limites de detecção apresentados pelo ICP-AES do IPT. Os motivos que levaram ao aumento desses limites de detecção já foram apontados no item 4.8.1.

Foi observado que há uma discrepância entre algumas análises realizadas através do ICP e do GDMS para valores de concentração acima do limite de detecção do ICP. Esta discordância se dá pela diferença na forma de amostragem existente nesses dois métodos. O GDMS analisa uma amostra com cerca de 18 $\mathrm{mm}^{2}$ de área total, uma região muito pequena se comparada com a área total da face da amostra ( $\cong 850 \mathrm{~mm}^{2}$ ). Foi observado que os intermetálicos presentes nas amostras próximo ao topo dos lingotes se encontram dispersos na matriz (ver Figuras 60 e 61). Ou seja, ainda que exista um determinado nível de impurezas na amostra na forma de precipitado, há uma grande chance de o GDMS analisar apenas a matriz de silício, fornecendo valores de concentração bem abaixo do valor 
médio. Por outro lado, o ICP fornece valores médios de concentração, já que possui um método de amostragem mais abrangente (item 4.8.1), que consta na pulverização e homogeneização de $9 \mathrm{~g}$ da amostra (constituindo $40 \%$ do peso total da amostra).

Uma evidência deste efeito pode ser observada na Figura 60, onde há a presença de intermetálicos na matriz de silício. A análise por GDMS referente a essa amostra forneceu valores extremamente baixos de concentração de impurezas (ver Tabela 27), o que não condiz com a presença desses intermetálicos, enquanto a análise de ICP forneceu valores de concentração muito maiores para essa mesma região da amostra. Provavelmente a análise de GDMS foi conduzida em uma região praticamente isenta de intermetálicos, fornecendo apenas os teores de elementos da matriz.

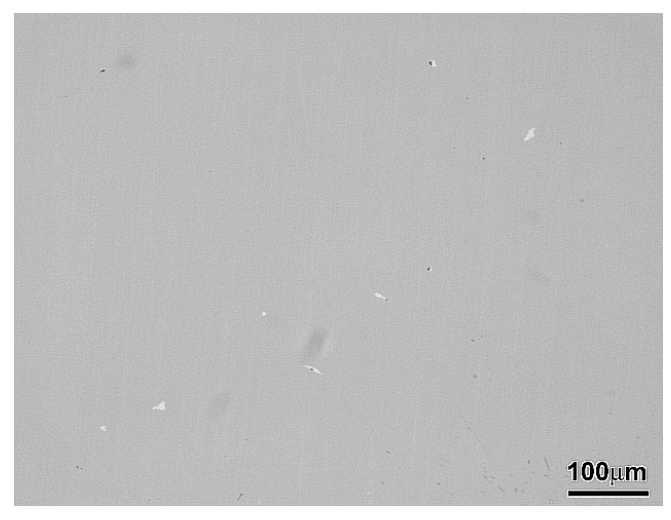

Figura 60 - Microscopia óptica de uma região do centro do lingote PR-110

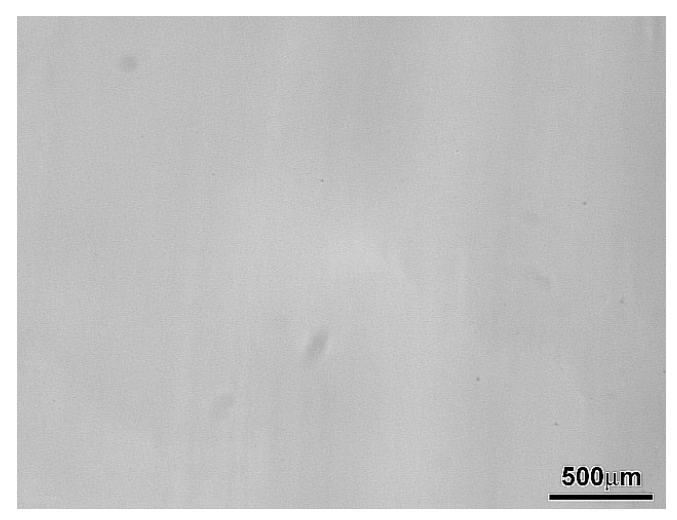

Figura 61 - Microscopia óptica de uma região abaixo do topo do lingote PR-110

Isso nos leva a concluir que a análise por GDMS só são confiáveis em amostras sem precipitação de intermetálicos e com a presença de interface plana.

\subsubsection{Transiente Inicial}

No capítulo 4 foi citado que, durante os ensaios preliminares, notou-se a presença de uma anomalia chamada no presente trabalho de "transiente inicial" causada pela solidificação mais rápida do silício líquido em contato com a placa de cobre extratora de calor. Essa condição impossibilitou o refino na região inicial do 
lingote e impôs condições de solidificação diferentes daquelas assumidas nos modelos de transporte de massa discutidos na literatura, onde o lingote está completamente líquido antes do início da solidificação direcional controlada.

Como se pode ver pelos perfis de concentração mostrados nas Figuras 31a (ensaios definitivos) e 32a (ensaios preliminares) este problema foi completamente solucionado utilizando uma montagem experimental diferente para a base do molde de quartzo.

\subsection{Macroestrutura dos Lingotes Refinados}

O transporte de calor e a macroestrutura bruta de solidificação estão intimamente relacionados [GARCIA, 2001]. Os grãos observados nas macroestruturas dos lingotes apresentados nas Figuras 33 e 37 são colunares, típicos de condições de transferência de calor unidirecional, com gradientes de temperaturas relativamente elevados. Estes grãos estão orientados aproximadamente na direção paralela ao fluxo de calor nos lingotes, ou seja, na direção axial.

Analisando as Figuras 33 e 36, nota-se que o aumento da velocidade de extração de calor causou a diminuição do tamanho de grão. Este aumento da velocidade de extração $(V)$ resulta em um aumento da taxa de resfriamento $(R)$, que pode aumentar a taxa de nucleação no sistema, reduzindo a largura dos grãos colunares.

A taxa de resfriamento pode ser estimada através de $R=G$. $V$, onde $G$ é o gradiente de temperatura próximo à interface sólido-líquido [KURZ, 1989]. No presente trabalho não foi possível medir $\mathrm{G}$ junto à interface sólido-líquido; porém o $\mathrm{G}$ no líquido antes do início da extração do molde foi medido (item 5.5), resultando em um valor médio de $3,4^{\circ} \mathrm{C} / \mathrm{cm}$. Este valor foi utilizado para se calcular uma estimativa da taxa de resfriamento, como mostra a Tabela 28.

Tabela 28 - Taxa de resfriamento para as diversas velocidades de extração do molde 


\begin{tabular}{|c|c|}
\hline $\mathbf{V}(\boldsymbol{\mu m} / \mathbf{s})$ & $\mathbf{R}\left({ }^{\circ} \mathbf{C} / \mathbf{s}\right)$ \\
\hline 5 & 0,0017 \\
\hline 10 & 0,0034 \\
\hline 20 & 0,0068 \\
\hline 110 & 0,0374 \\
\hline
\end{tabular}

A macroestrutura do lingote EP-08 (ver Figura 41) mostra que o contato direto do silício ao solidificar com a base refrigerada resulta também em uma diminuição do tamanho de grão (principalmente na base do lingote) quando comparado ao tamanho observado nas macrografias para os lingotes solidificados com a mesma velocidade, mas em uma base isolante (Figuras 33 e 37). A solidificação em contato com a base refrigerada ocorreu na presença de um gradiente de temperatura maior, resultando também em uma maior taxa de resfriamento e uma conseqüente diminuição do tamanho de grão.

Observa-se que os grãos que solidificam próximos à parede do molde têm uma orientação ligeiramente inclinada e não completamente paralela ao eixo do lingote (ver Figura 33). Isto parece mostrar que houve alguma transferência de calor radial nesse ensaio. O fluxo de calor radial será tão mais importante quanto menor for o fluxo longitudinal. Isto parece ser verdade quando se observa que na macroestrutura do lingote preliminar (Figura 41), onde o fluxo de calor longitudinal é acentuado pela base refrigerada, o desvio da orientação paralela é menor junto à parede.

Nas macrografias dos lingotes solidificados mais rapidamente (GM-110 e PR110) percebe-se a ausência de grãos colunares (presentes nos demais ensaios) e a presença de grãos equiaxiais na macroestrutura bruta de solidificação. Este efeito foi observado na literatura [FLEMINGS, 1974], onde se concluiu que a diminuição do super-resfriamento constitucional, calculado por $G / V$, devido a um aumento da velocidade de extração do molde da zona quente para a zona fria resulta no aparecimento de grãos equiaxiais que impedem o crescimento dos colunares. 


\subsection{Estabilidade da Interface Sólido-Líquido}

A interface plana propicia uma maior segregação de elementos sob condições de agitação do líquido, fornecendo, portanto, condições para um maior refino. Por outro lado, quando a morfologia da interface não é plana, como, por exemplo, no caso de uma interface dendrítica ou celular, grande parte do soluto pode ficar aprisionada entre os braços de dendritas ou células, impossibilitando o transporte de soluto para o seio da fase líquida e dificultando o processo de refino [KURZ e FISHER, 1989]. Este aprisionamento de soluto resulta na microssegregação, que permite observar, à temperatura ambiente, os contornos das dendritas ou células, mostrando que estas morfologias estavam presentes durante a solidificação

Nas baixas concentrações de elementos existentes nas amostras do presente trabalho, não foi possível observar estes vestígios da estrutura dendrítica. As observações realizadas em microscópio óptico (ver Figuras 45 a 46) não mostraram a microssegregação típica de uma estrutura dendrítica ou celular, supondo que elas estejam presentes em alguma das condições estudadas.

Existem diversas evidências que mostram que, na presença de células ou dendritas, o acúmulo de soluto entre as mesmas pode resultar na precipitação de outras fases sólidas a partir do líquido. No próprio silício, observa-se na solidificação não controlada ou naquelas realizadas com velocidades relativamente grandes de extração do molde, a presença de intermetálicos entre os grãos. Desta forma, a presença de intermetálicos será utilizada no presente trabalho como evidência da existência de uma interface celular ou dendrítica.

Uma tentativa de se identificar a presença da morfologia celular ou dendrítica foi realizada em um ensaio com SiGM extraído à uma velocidade de $5 \mu \mathrm{m} / \mathrm{s}$ com adição de $3 \%$ de germânio. Na metodologia (item 4.5) foi comprovado que, na solidificação não controlada, este teor de Ge causaria uma microssegregação que permitiria revelar a estrutura dendrítica. No entanto, a observação por microscopia óptica e MEV (Figura 53 e 54) de amostras do centro do lingote referente a esse ensaio não revelou dendritas, confirmando que a interface sólido-líquido neste ensaio era provavelmente plana. 
A diminuição da quantidade de soluto favorece a formação de morfologias planas na interface sólido/líquido. Logo pode-se concluir que, se no ensaio com SiGM contendo 3\% de germânio conseguiu-se atingir a interface plana, pode-se esperar a mesma morfologia da interface para os ensaios onde se usou o SiGM ou o SiR (ensaios GM-05 e PR-05) na mesma velocidade de extração (5 $\mu \mathrm{m} / \mathrm{s}$ ). Além disso, nestes ensaios não foi observada a presença de intermetálicos nas regiões centrais dos lingotes (ver Figuras 45 e 46), também evidenciando a morfologia plana da interface.

Foi observado que, a diminuição da velocidade de extração do molde (mantendo constante a composição inicial do silício) causa uma diminuição da presença de intermetálicos no lingote refinado, como pode ser visto comparando-se as Figuras 45c e 47. Este efeito é mais visível no SiGM devido ao seu alto nível de impurezas. Para maiores velocidades de extração, percebe-se a presença de intermetálicos espalhados por toda a extensão do lingote (Figura 49). Para velocidades mais baixas, nota-se que estes intermetálicos se concentram na região do topo, confirmando o efeito de refino.

A Tabela 29 abaixo mostra de modo resumido a presença ou não de intermetálicos nos lingotes. A presença de poucos intermetálicos nas micrografias de SiR é explicada pelos baixos teores de impurezas existentes na matéria prima.

Tabela 29 - Esquema demonstrativo da presença de intermetálicos

\begin{tabular}{|c|c|c|c|c|c|c|}
\hline \multicolumn{5}{|c|}{ SiGM } & \multicolumn{3}{c|}{ SiR } \\
\hline & \multicolumn{3}{|c|}{ SEREÇA DE INTERMETÁLICOS NOS LINGOTES SOLIDIFICADOS } \\
\hline $\mathrm{V}(\boldsymbol{\mu \mathrm { m }} / \mathbf{s})$ & Base & Centro & Topo & Base & Centro & Topo \\
\hline $\mathbf{1 1 0}$ & SIM & SIM & SIM & SIM & SIM & SIM \\
\hline $\mathbf{2 0}$ & SIM & SIM & SIM & NÃO & NÃO & SIM \\
\hline $\mathbf{1 0}$ & NÃO & NÃO & SIM & NÃO & NÃO & SIM \\
\hline $\mathbf{5}$ & NÃO & NÃO & SIM & NÃO & NÃO & SIM \\
\hline
\end{tabular}

Por tudo isso, está-se confirmando a teoria do super-resfriamento constitucional, que indica que uma diminuição da velocidade de solidificação, que é 
aproximadamente igual à velocidade de extração do molde da zona quente para a zona fria, resulta em uma interface sólido-líquido cada vez mais próxima da plana, sem a microssegregação inerente às interfaces celulares e dendríticas. Como também pode ser previsto pela teoria do super-resfriamento constitucional, a diminuição da concentração dos elementos na composição inicial do Si causa um efeito semelhante em promover a interface plana, diminuindo a presença de intermetálicos.

Finalmente, as análises por microssonda (EDS) apresentadas nas Figuras 56 a 58 mostram que os precipitados intermetálicos observados nos lingotes são constituídos principalmente de Fe, Al, Mn, Ti e Cr, como observado em outros trabalhos de solidificação não controlada de Si [FERREIRA NETO, 1999].

\subsection{Efeito da Velocidade de Extração e da Concentração Inicial}

\subsubsection{Efeito da Velocidade de Extração do Molde}

$\mathrm{Na}$ análise deste item serão usados apenas os perfis dos ensaios realizados com o SiGM, pois os lingotes refinados a partir do SiR apresentaram quase sempre teores de elementos abaixo dos limites de detecção das técnicas analíticas utilizadas. A Figuras 62 a 71 mostram uma comparação entre os perfis de concentração de vários elementos para as velocidades de extração do molde utilizadas neste trabalho nos ensaios de refino do SiGM. A concentração adimensional foi calculada através do quociente $C_{s} / C_{0}$, onde $C_{s}$ é a concentração do elemento no lingote obtido e $\mathrm{C}_{0}$ é a concentração do elemento no SiGM (matériaprima), indicada na Tabela 7. A fração de sólido para cada ponto do gráfico foi obtida tomando-se a distância do ponto até o início do lingote e dividindo pelo comprimento total do lingote. 


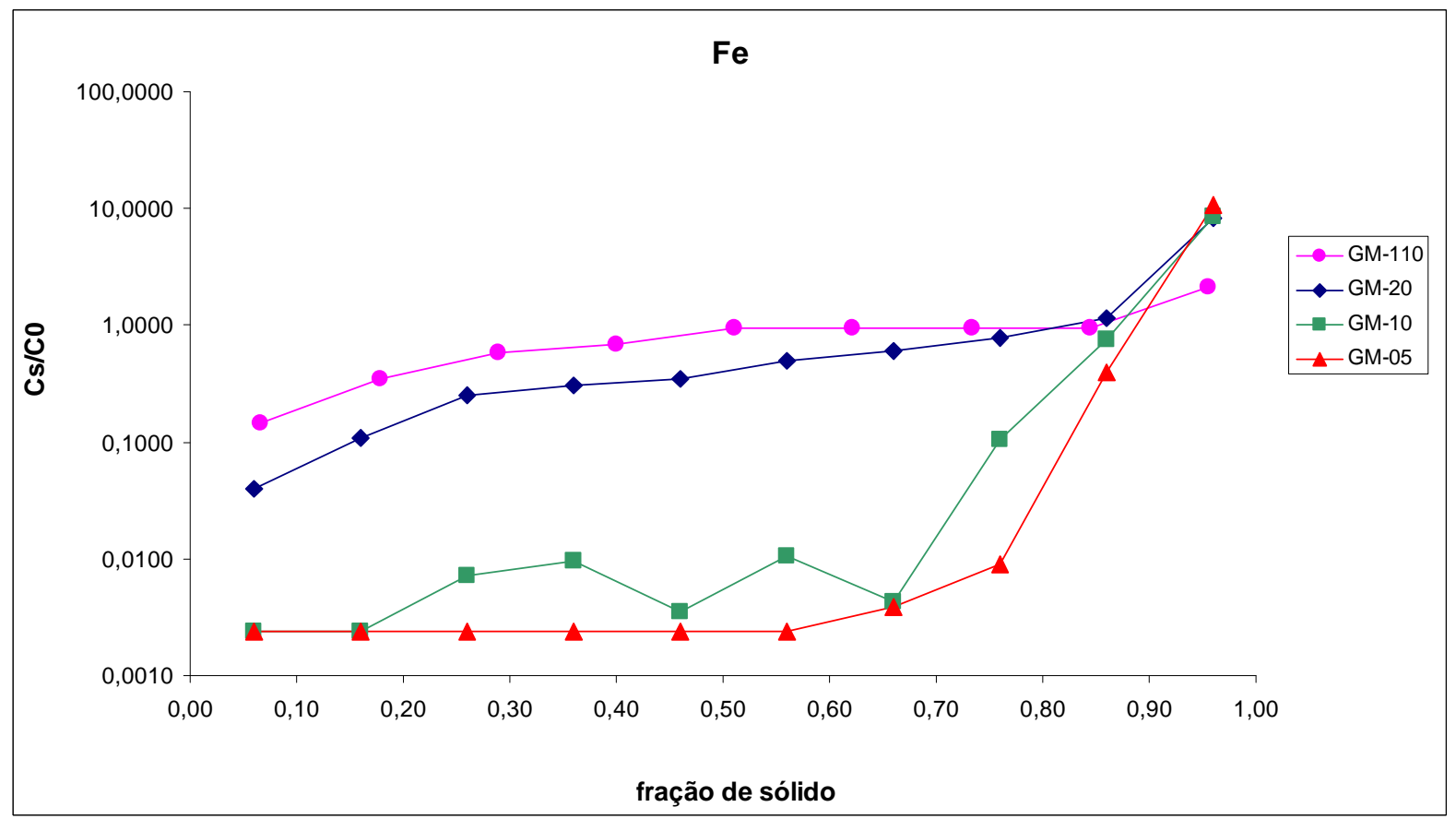

Figura 62 - Concentração adimensional de Fe vs fração de sólido para os ensaios realizados com SiGM nas quatro diferentes velocidades de extração do molde.

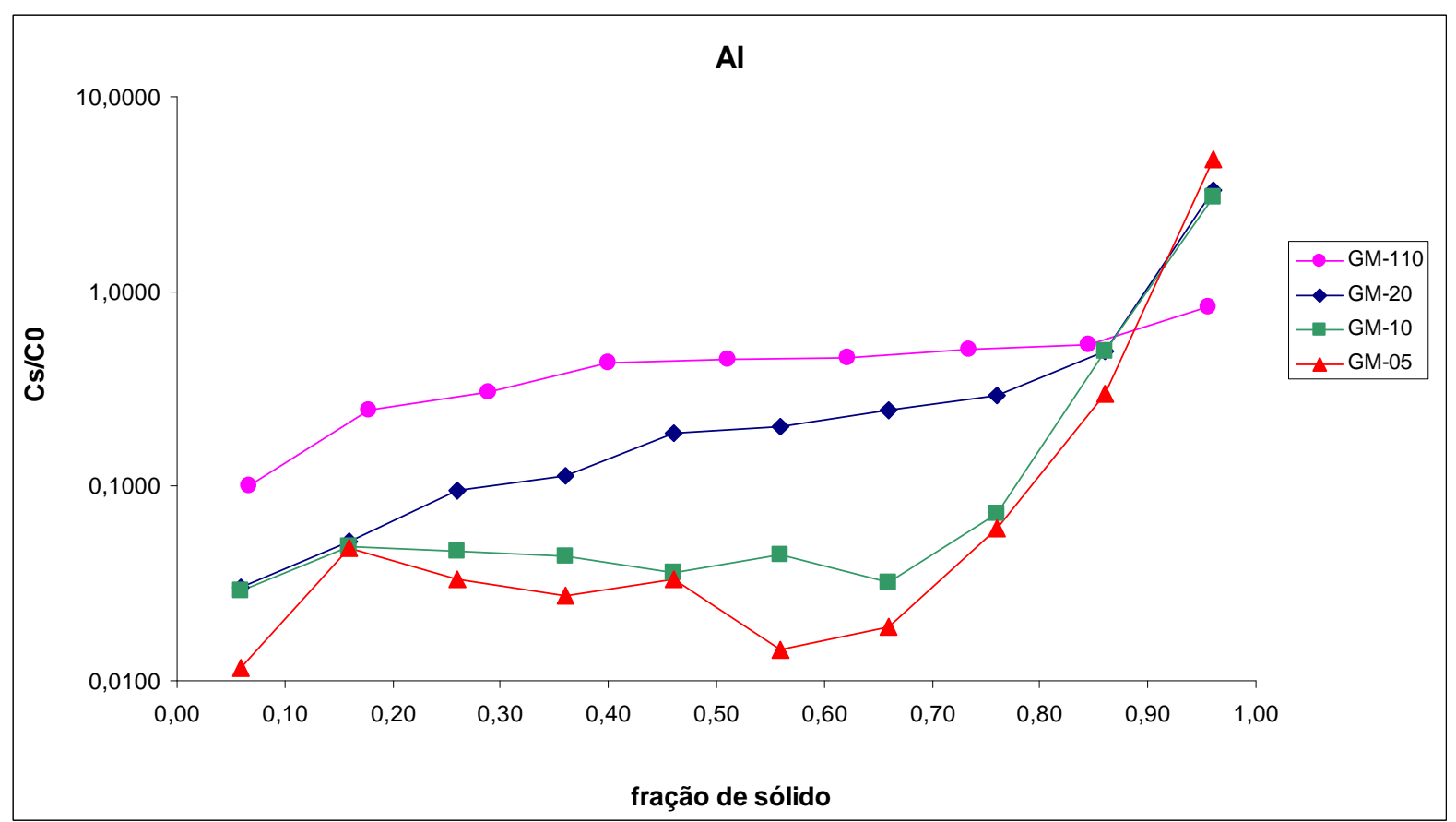

Figura 63 - Concentração adimensional de Al vs fração de sólido para os ensaios realizados com SiGM nas quatro diferentes velocidades de extração do molde. 


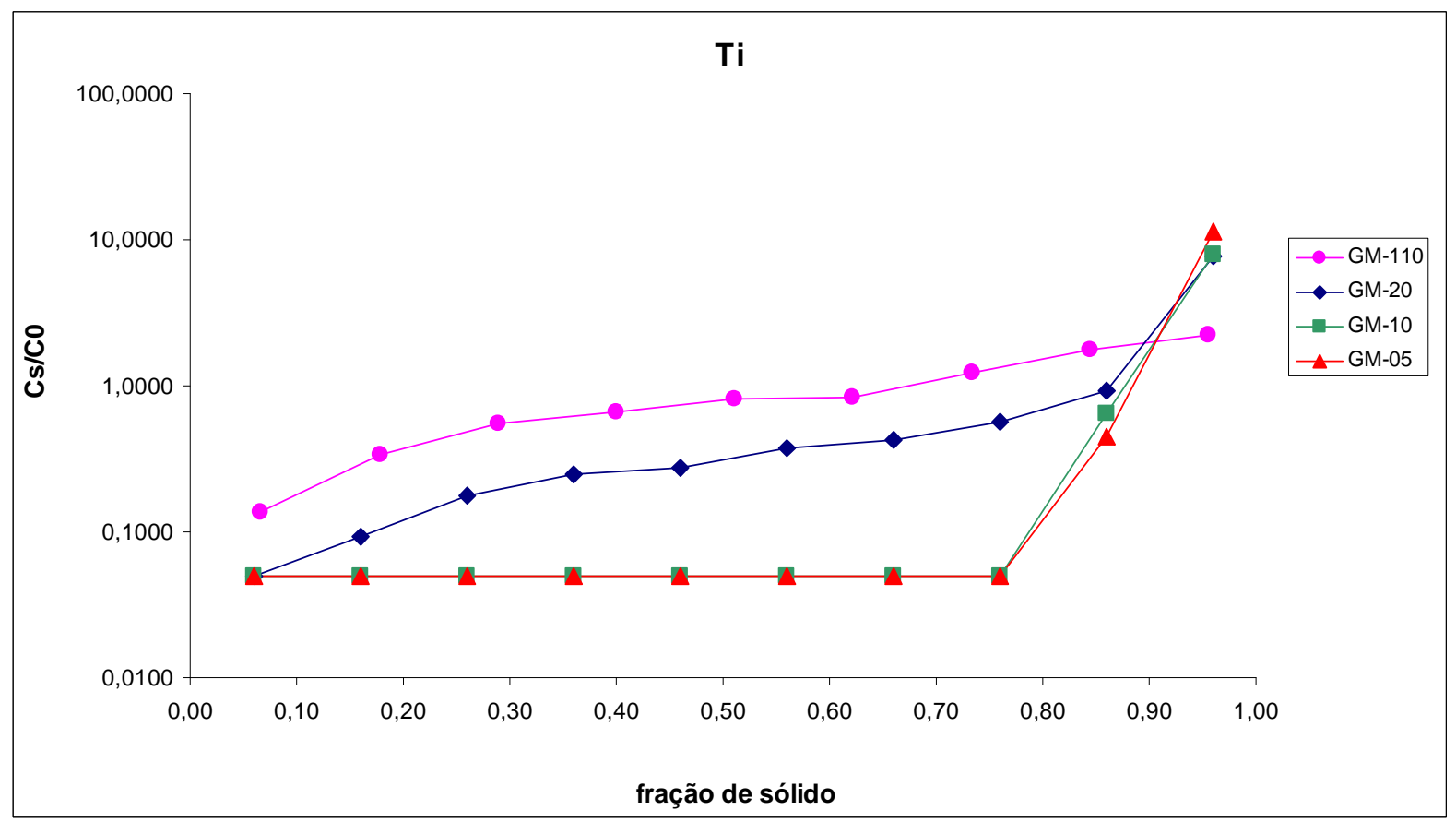

Figura 64 - Concentração adimensional de Ti vs fração de sólido para os ensaios realizados com SiGM nas quatro diferentes velocidades de extração do molde.

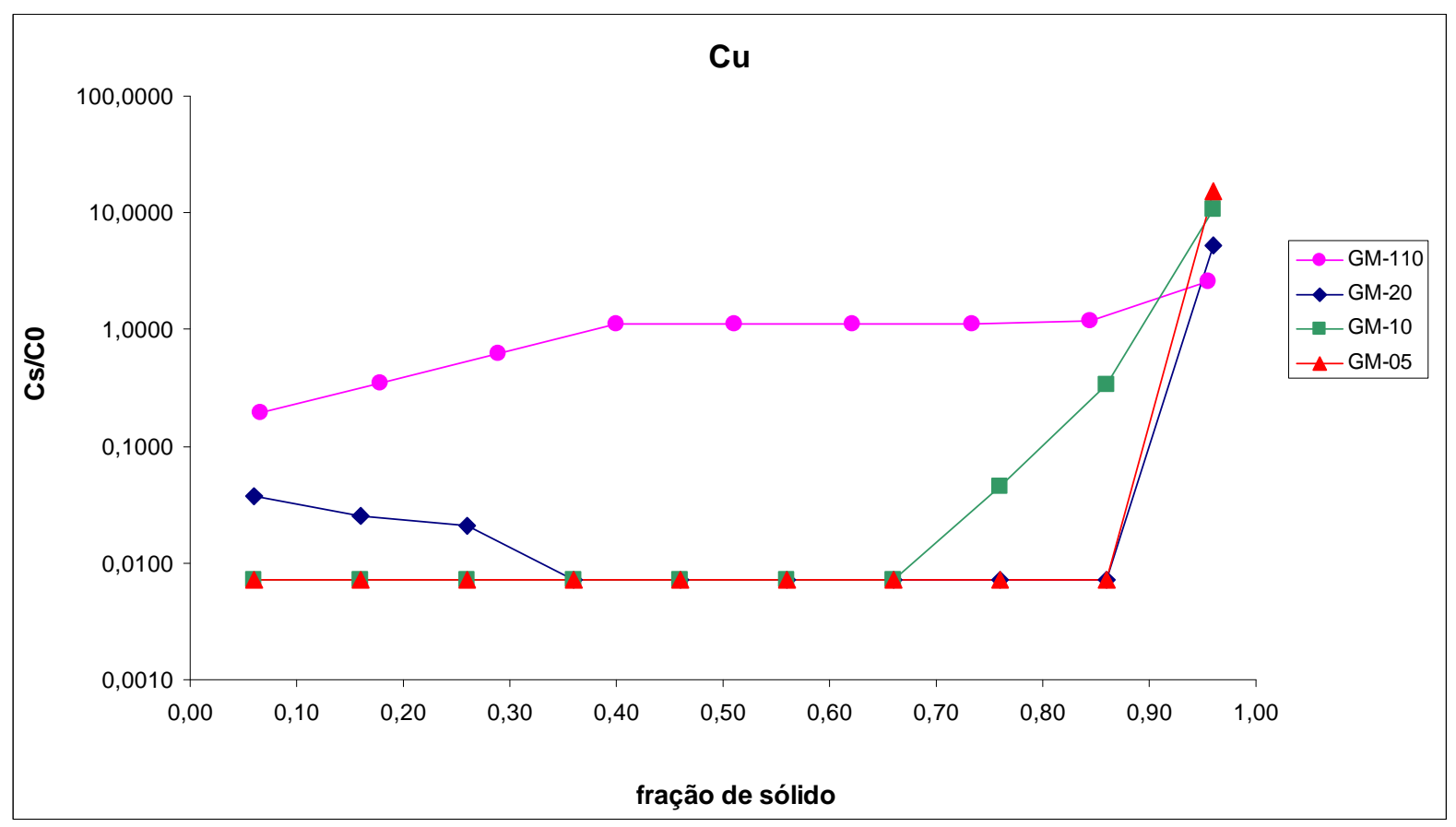

Figura 65 - Concentração adimensional de Cu vs fração de sólido para os ensaios realizados com SiGM nas quatro diferentes velocidades de extração do molde. 


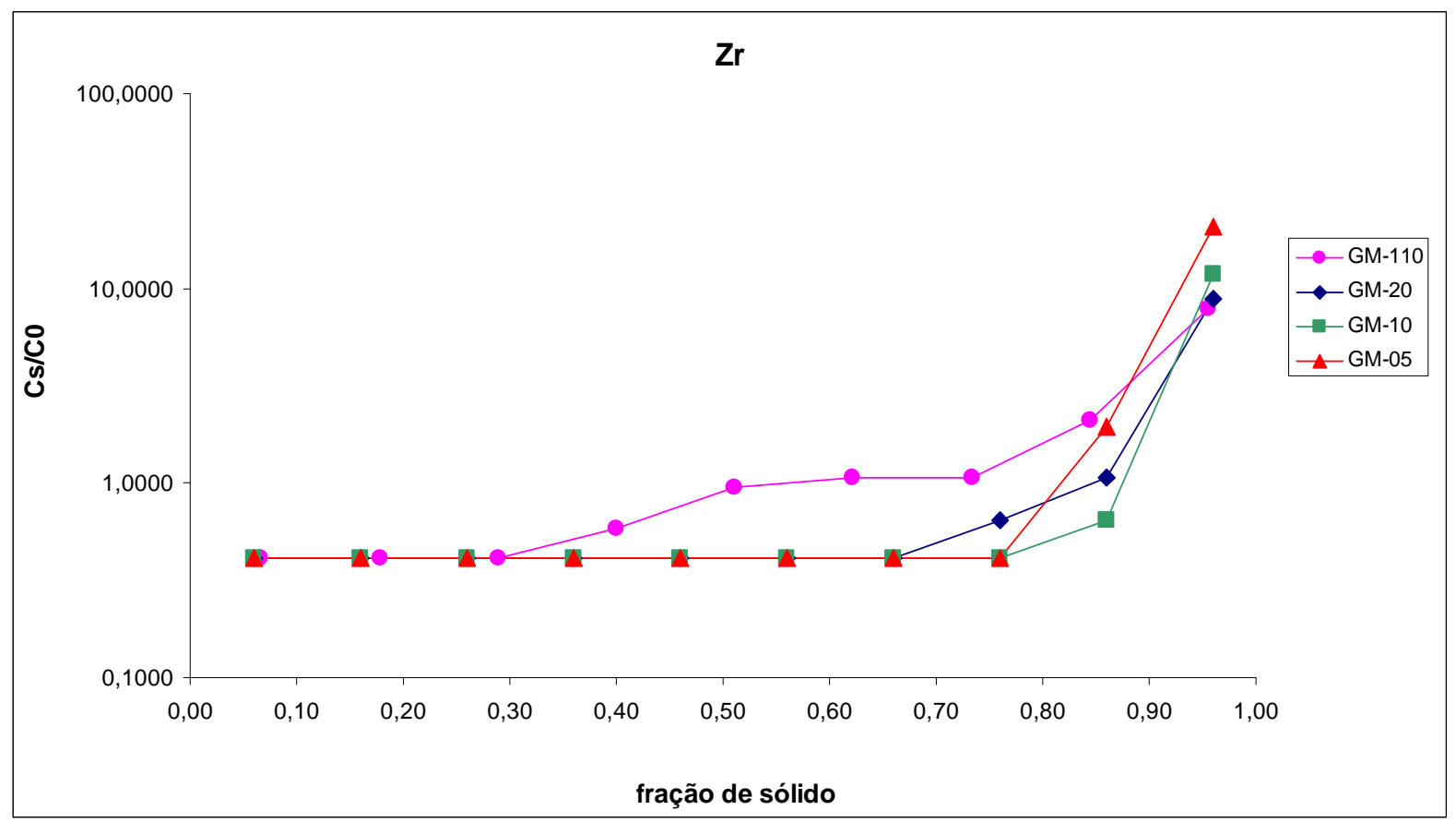

Figura 66 - Concentração adimensional de $\mathrm{Zr}$ vs fração de sólido para os ensaios realizados com SiGM nas quatro diferentes velocidades de extração do molde.

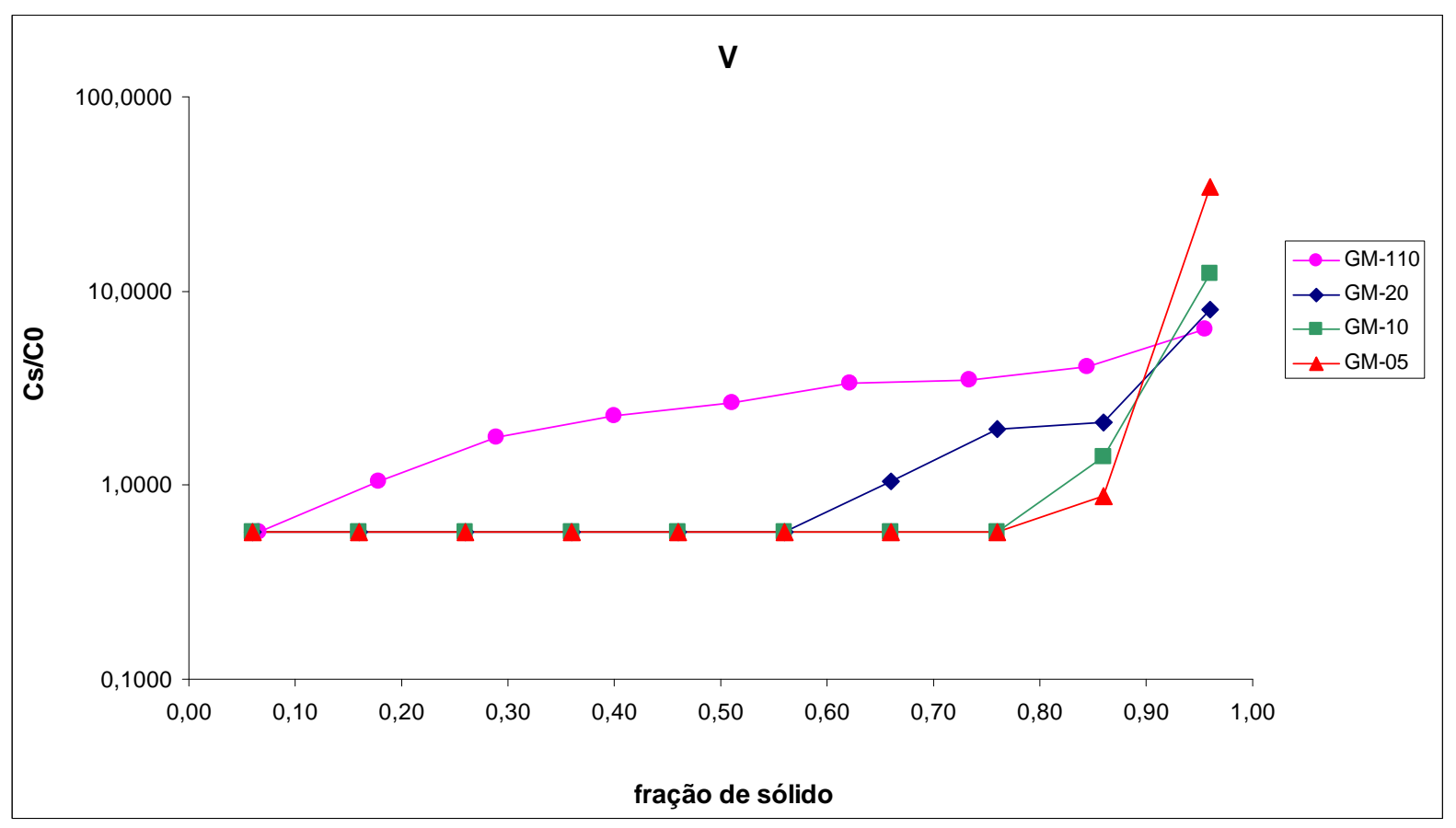

Figura 67 - Concentração adimensional de $V$ vs fração de sólido para os ensaios realizados com SiGM nas quatro diferentes velocidades de extração do molde. 


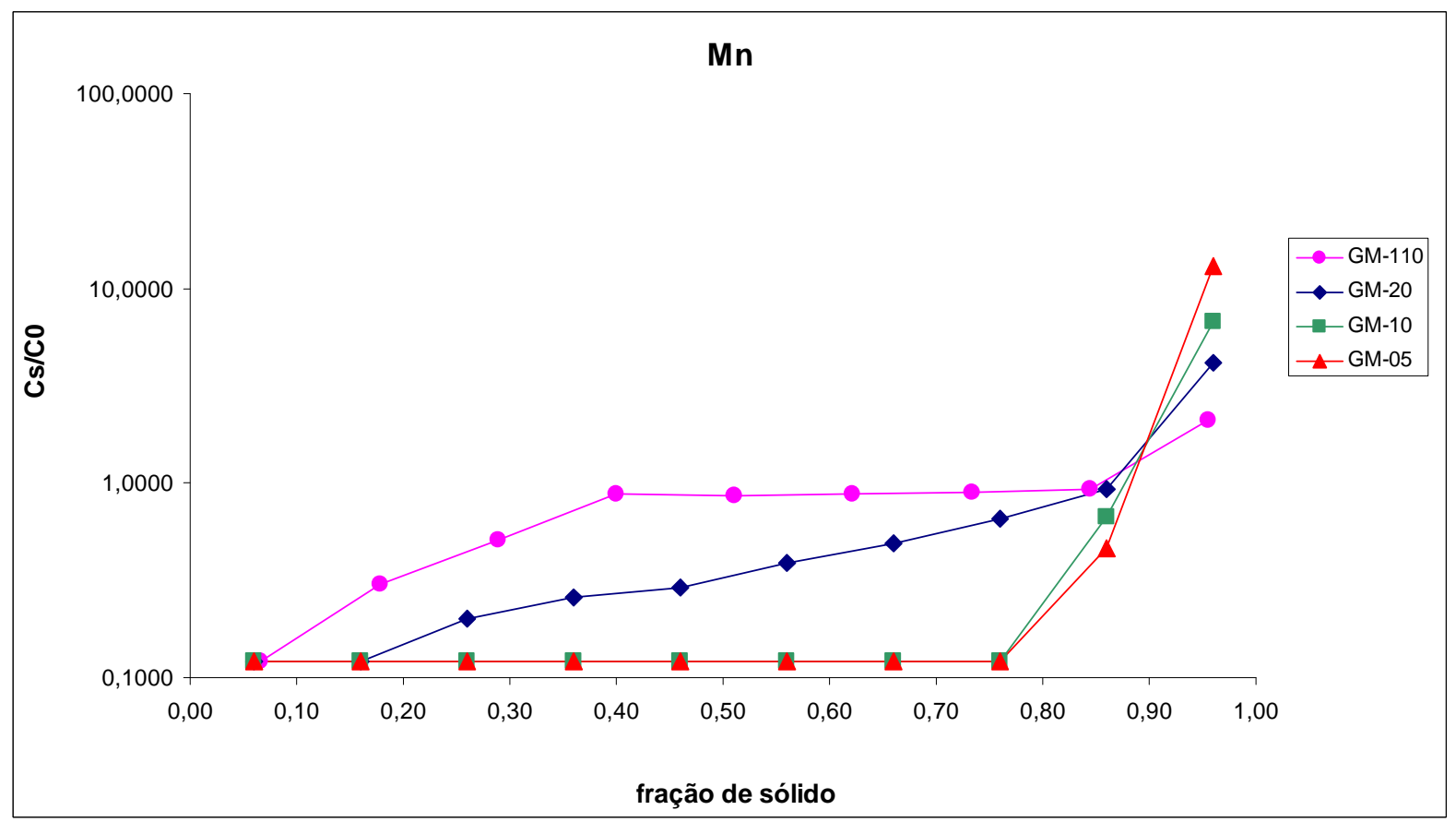

Figura 68 - Concentração adimensional de Mn vs fração de sólido para os ensaios realizados com SiGM nas quatro diferentes velocidades de extração do molde.

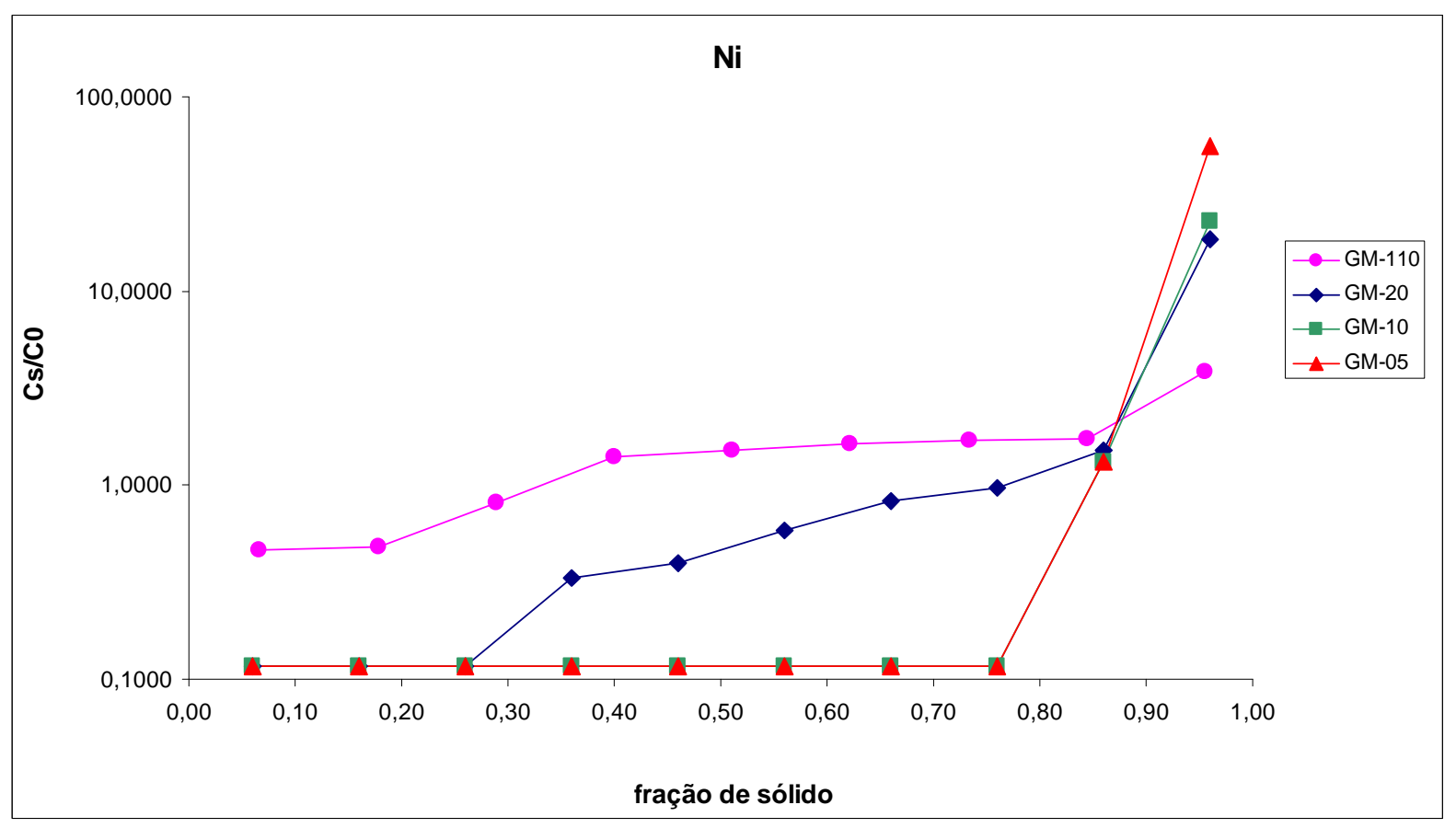

Figura 69 - Concentração adimensional de Ni vs fração de sólido para os ensaios realizados com SiGM nas quatro diferentes velocidades de extração do molde. 


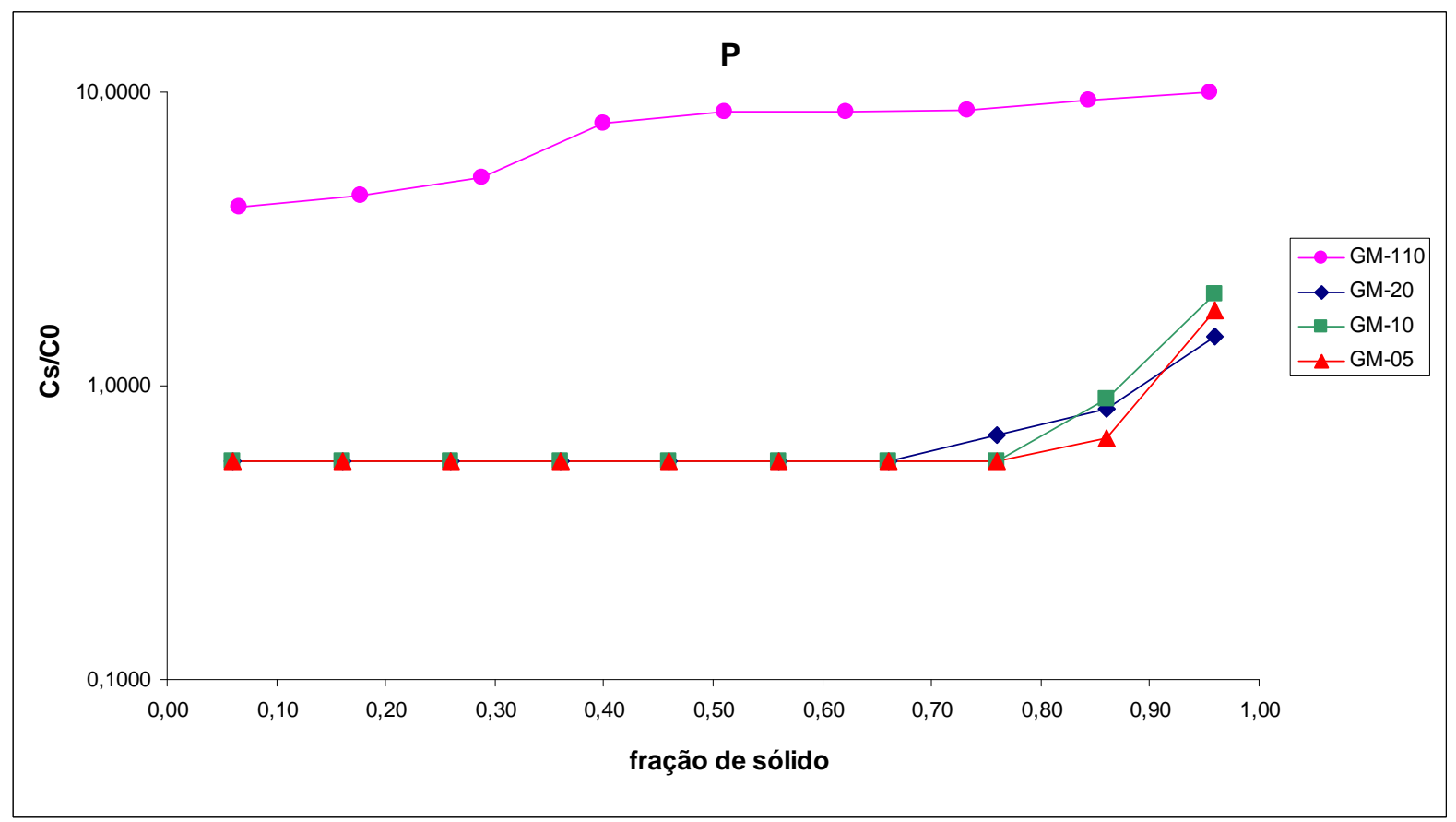

Figura 70 - Concentração adimensional de P vs fração de sólido para os ensaios realizados com SiGM nas quatro diferentes velocidades de extração do molde.

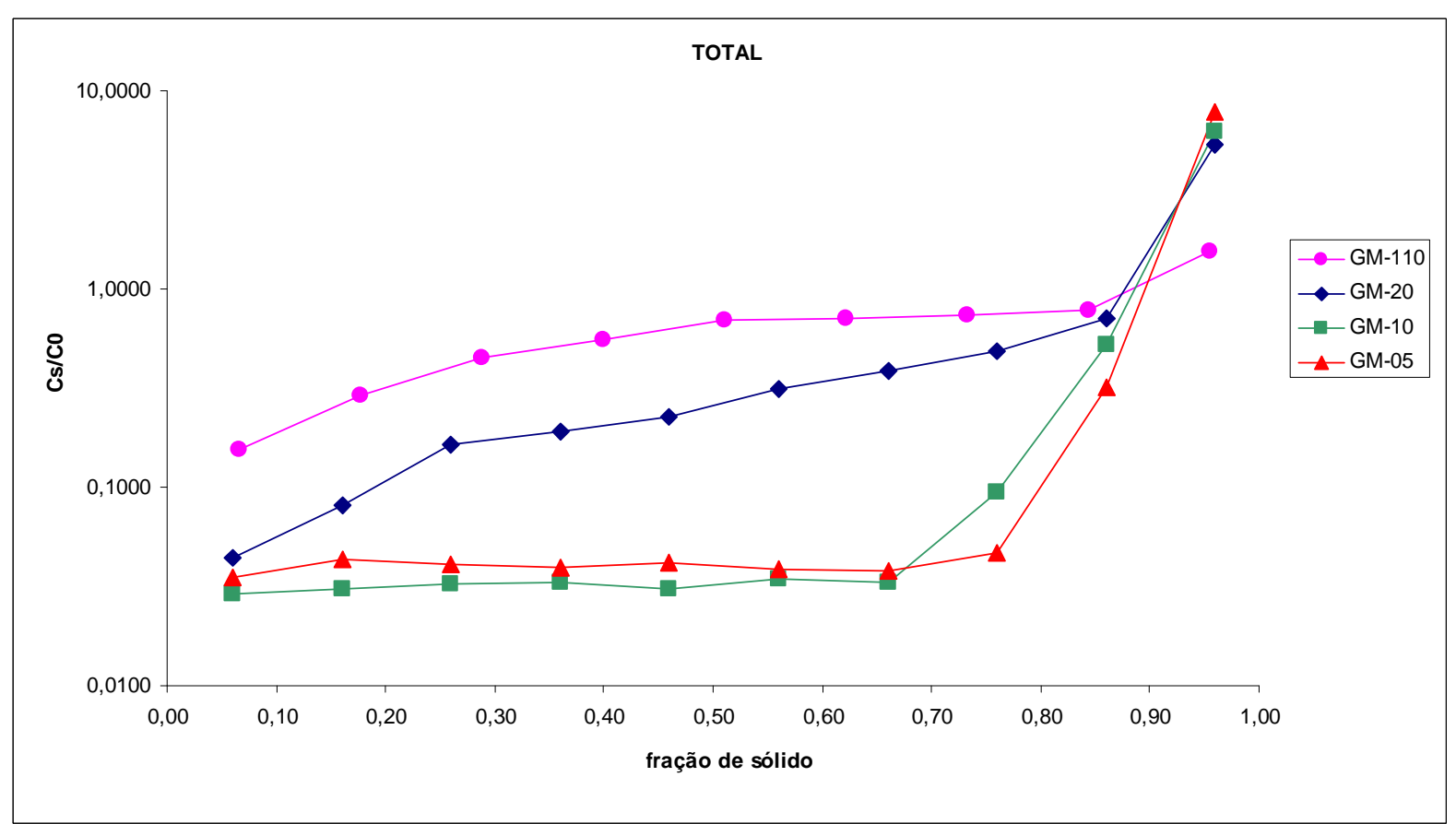

Figura 71 - Concentração adimensional de Total vs fração de sólido para os ensaios realizados com SiGM nas quatro diferentes velocidades de extração do molde.

Observa-se que os perfis acima seguem um comportamento padrão que consta de baixos valores nas regiões iniciais e no centro dos lingotes, seguido de um aumento de concentração na região final. Este formato está em acordo com o formato típico do perfil de Scheil [1942] mostrado utilizando o elemento Fe como exemplo. Este formato indica que houve algum tipo de transporte de soluto auxiliado 
por convecção do líquido, ou seja, caso o transporte no líquido ocorresse apenas por difusão, o perfil medido apresentaria um transiente inicial que não foi observado.

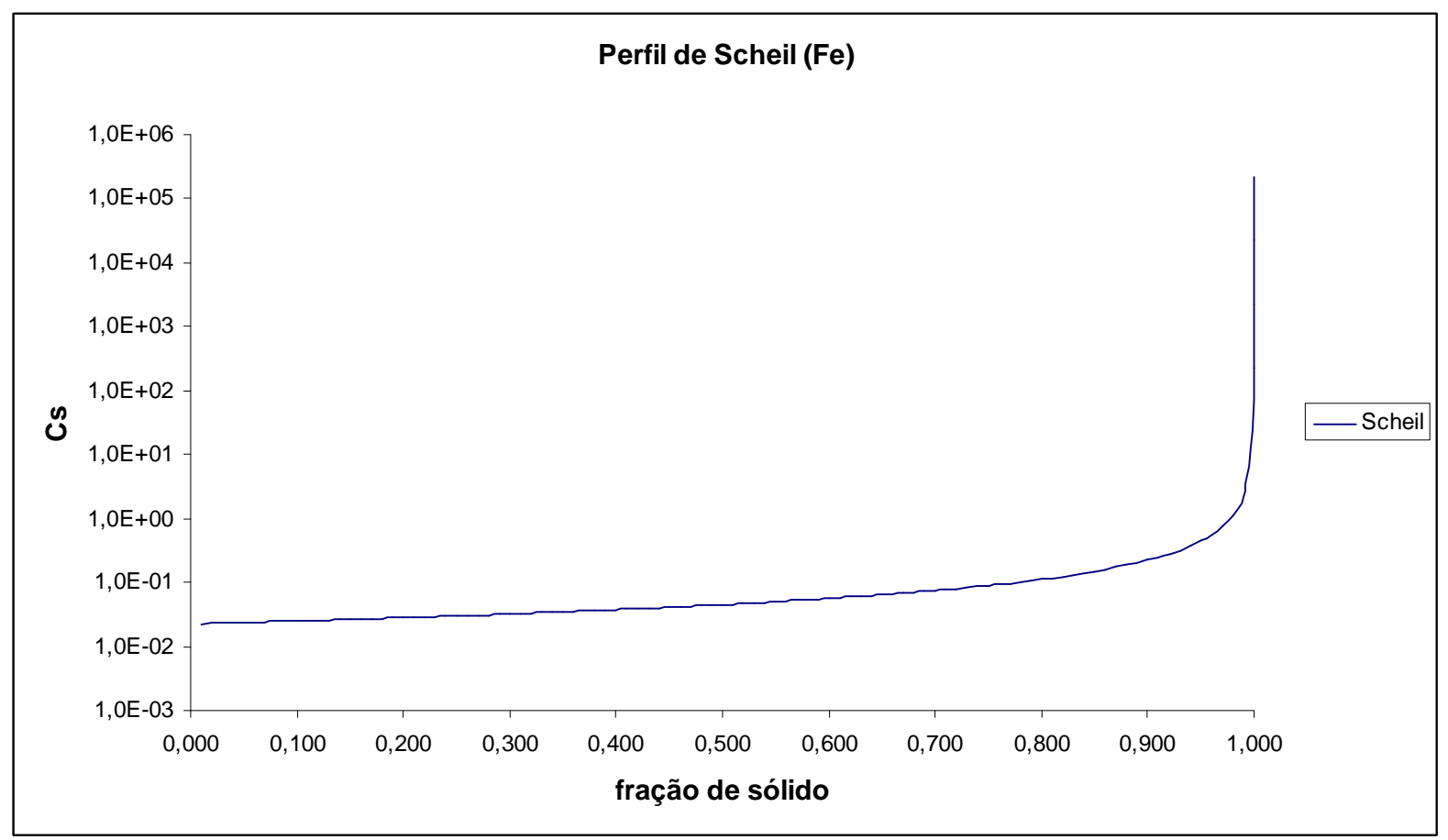

Figura 72 - Perfil de Scheil [1942] para o Fe $\left(C_{0}=2800\right.$ ppm; $k=8 \times 10^{-6}$.

Os perfis apresentados nas Figuras 62 a 71 mostram que, quanto menor a velocidade de extração do molde, menor a concentração dos elementos na região central do lingote. Em uma velocidade de extração de $110 \mu \mathrm{m} / \mathrm{s}$ (ensaio GM-110), a menor concentração do perfil de Fe é da ordem de 400 ppm (Figura 18b). Nota-se que, durante toda a extensão do lingote, as concentrações de Fe permaneceram muito altas em comparação com os ensaios de velocidade mais lenta, mostrando um refino não satisfatório.

No perfil obtido para uma velocidade de extração de $5 \mu \mathrm{m} / \mathrm{s}$ (ensaio GM-05), percebe-se que o refino foi bem mais efetivo. Na região central do lingote observouse que o valor obtido encontra-se abaixo do limite de detecção do ICP. Observando os valores de concentração fornecidos pelo GDMS (ver Tabelas 12 a 14) percebe-se que os teores de Fe estão variando numa faixa entre 0,14 a 1,6 ppm. Estes são teores tipicamente encontrados durante o processo de obtenção do SiGS [SARTI e EINHAUS, 2002]. 
De forma geral, houve uma redução significativa de $\cong 2800$ ppm de Fe no silício inicial (SiGM) para teores na faixa de 1 ppm na região central do lingote refinado. O mesmo vale para boa parte das impurezas analisadas por GDMS. Levando-se em consideração apenas as análises por ICP, grande parte das impurezas encontrou-se abaixo do limite de detecção para a maioria dos casos. Neste ensaio especificamente (GM-05), a concentração de Fe no topo do lingote atingiu níveis da ordem de 30000 ppm, indicando com isso uma macrossegregação considerável durante a solidificação direcional.

No perfil referente ao $\mathrm{P}$ (Figuras 30a e b), percebe-se algum efeito de refino, embora o seu coeficiente de partição $(k=0,35)$ seja relativamente elevado em comparação ao dos outros elementos. No perfil de Ti (Figura 22a e b) observam-se valores abaixo do limite de detecção do ICP. Mas, tomando-se o resultado obtido por GDMS, vê-se que o teor de Ti no centro do lingote foi de 0,083 ppm no caso do lingote GM-05 e 0,001 ppm no caso do lingote GM-10 (ver Tabelas 12 e 18). Ambos os valores encontram-se muito abaixo do nível especificado para o silício grau solar (<1 ppm) [SARTI e EINHAUS, 2002]. O mesmo ocorre para o $\mathrm{Cr}$, que com valores de concentração próximos a 0,03 ppm (ver Tabelas 12 a 14) também se encontra dentro do limite especificado para o SiGS (<1 ppm). Estes valores estão em acordo com outros encontrados na literatura [PIZZINI, 2005].

Outras impurezas tais como $\mathrm{Cu}, \mathrm{V}, \mathrm{Zr}, \mathrm{Mn}$, e $\mathrm{Ni}$ seguem um comportamento similar, com valores de concentração abaixo do limite de detecção do ICP nos primeiros $80 \%$ do lingote e um aumento de concentração no topo do lingote. Este comportamento também se observa para os perfis do ensaio GM-20, mas com valores de concentração no centro do lingote acima dos valores encontrados nos lingotes de extração mais lenta. Mas mesmo para esse ensaio ainda se observou um efeito de refino para vários elementos, como mostram claramente os perfis de concentração.

No perfil de concentração total de impurezas (Figuras 31a e b) percebe-se que, quando se utiliza uma velocidade de extração do molde de $110 \mu \mathrm{m} / \mathrm{s}$, a concentração no centro do lingote atinge um valor médio de $\cong 4000 \mathrm{ppm}$. Por outro lado, ao se utilizar velocidades menores, ou seja, 5 e $10 \mu \mathrm{m} / \mathrm{s}$, as concentrações médias são reduzidas para aproximadamente 200 ppm, levando em consideração a 
presença do B e P que não são refinados por solidificação direcional. Isto confirma o forte efeito da velocidade sobre o refino.

Nota-se que os valores de concentração fornecidos pela análise por GDMS permaneceram na região entre a linha $\mathrm{kC}_{0}$ e $\mathrm{kC}_{\text {máx }}$ (ver Figuras 18 a 29). Isto pode ser um indicativo da confiabilidade dos valores de $\mathrm{k}$ obtidos através da literatura.

Outro importante efeito da velocidade da interface sólido-líquido é sobre os parâmetros de transporte de massa. Encontram-se na literatura diversos estudos discutindo a influência da velocidade da interface sobre o coeficiente efetivo de partição $\left(K_{\text {eff }}\right)$. Tewari et al [1993] e Ojha et al [1999] estudaram este efeito em ligas de $\mathrm{Pb}-\mathrm{Sn}$ e calcularam alguns valores de $K_{\text {eff }}$ para este sistema.

Utilizando os valores de concentração no sólido obtidos pelas análises químicas e aplicando-os à equação de Scheil (Eq 24) será possível obter o coeficiente efetivo de partição para um dado elemento em uma dada velocidade de extração do molde, como pode ser visto nas Figuras 73, 74 e 75.

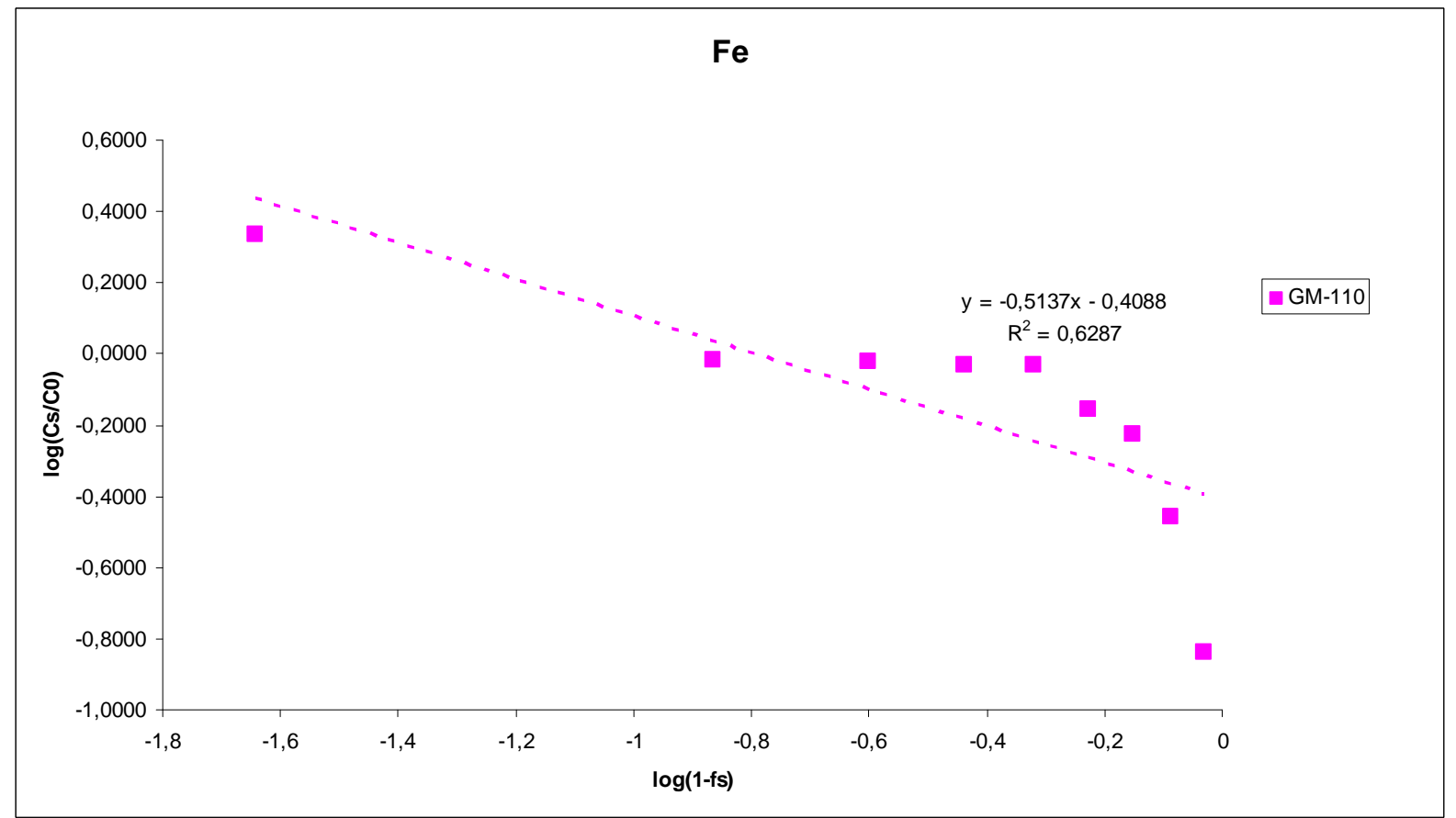

Figura 73 - Regressão linear $(\log (\mathrm{Cs} / \mathrm{C} 0)$ vs $\log (1-\mathrm{fs}))$ para obtenção do coeficiente efetivo de partição do Fe no ensaio GM-110 


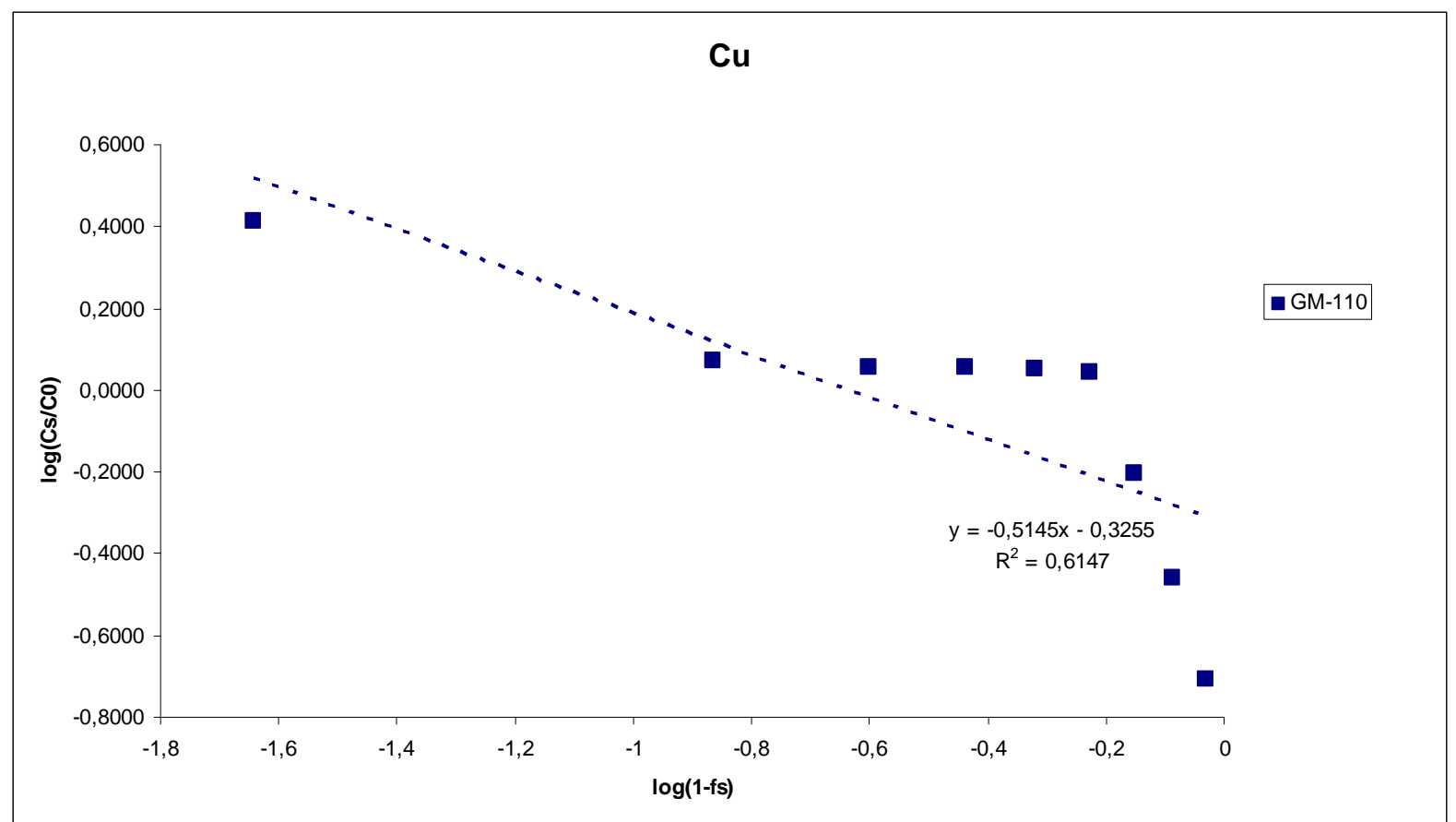

Figura 74 - Regressão linear $(\log (\mathrm{Cs} / \mathrm{C} 0)$ vs $\log (1-\mathrm{fs}))$ para obtenção do coeficiente efetivo de partição do Cu no ensaio GM-110

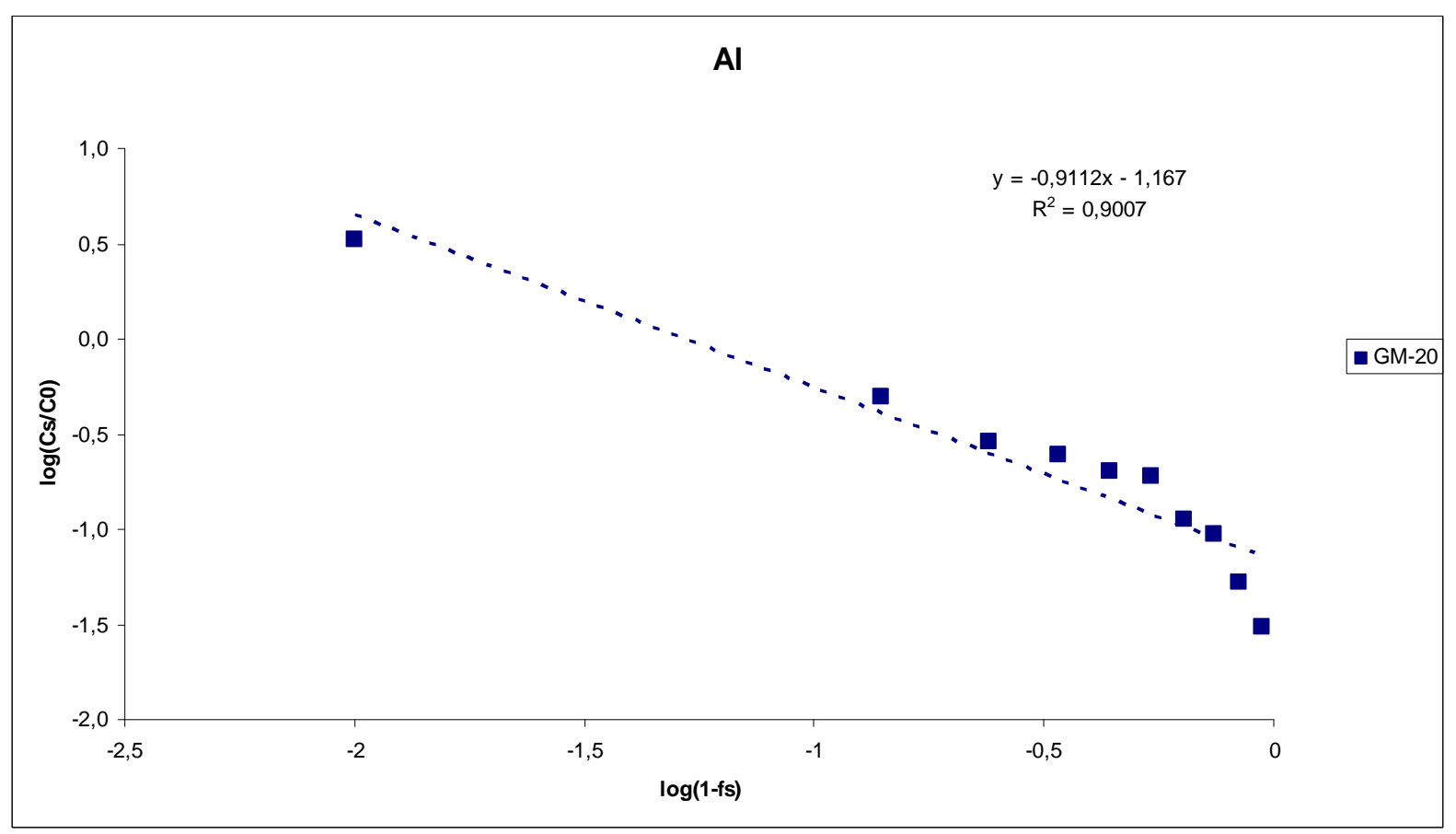

Figura 75 - Regressão linear $(\log (\mathrm{Cs} / \mathrm{C} 0)$ vs $\log (1-\mathrm{fs}))$ para obtenção do coeficiente efetivo de partição do Al no ensaio GM-20

O coeficiente efetivo foi calculado de duas formas diferentes, ambas através da equação de Scheil: 


$$
C_{S}=k_{e f f} C_{0}(1-f S)^{\left(k_{e f f}-1\right)}
$$

Após um simples rearranjo, pode-se reescrevê-la como:

$$
\log \frac{C_{S}}{C_{0}}=\log k_{e f f}+\left(k_{e f f}-1\right) \log (1-f s)
$$

Onde o termo log $k_{\text {eff }}$ é o coeficiente linear e o termo $\left(k_{\text {eff }}-1\right)$ é o coeficiente angular. Ambos são retirados dos gráficos apresentados 73 a 75 .

Após realizar esses cálculos, foram obtidos os valores do coeficiente efetivo de partição para o Al para o ensaio GM-20 e Fe e Cu para o ensaio GM-110. Esses valores estão mostrados na Tabela 30 abaixo. O cálculo para outros elementos e velocidades de extração do molde ficou impossibilitado devido principalmente a valores abaixo dos limites de detecção do método analítico.

Tabela 30 - Coeficientes de partição efetivos para Fe, Al, e Cu no silício. $\mathrm{K}_{\text {eff } 1}$ foi calculado a partir de logk $\mathrm{k}_{\mathrm{eff}}$ e $\mathrm{K}_{\mathrm{eff} 2}$ a partir de $\mathrm{K}_{\mathrm{eff}}-1$, ambos na equação de Scheil[1942]

\begin{tabular}{|c|c|c|c|}
\hline Elemento & Velocidade & $\mathbf{K}_{\text {eff1 }}$ & $\mathbf{K}_{\text {eff2 }}$ \\
\hline $\mathrm{Fe}$ & $110 \mu \mathrm{m} / \mathrm{s}$ & 0,40 & 0,48 \\
\hline $\mathrm{Cu}$ & $110 \mu \mathrm{m} / \mathrm{s}$ & 0,47 & 0,48 \\
\hline $\mathrm{Al}$ & $20 \mu \mathrm{m} / \mathrm{s}$ & 0,07 & 0,08 \\
\hline
\end{tabular}

Pode-se observar na tabela acima que os valores de $\mathrm{k}_{\text {eff }}$ para o $\mathrm{Fe}$ e o $\mathrm{Cu}$ estão muito acima dos seus respectivos valores de $\mathrm{k}_{0}\left(\mathrm{Fe}=8 \times 10^{-6}, \mathrm{Cu}=4 \times 10^{-4}\right)$, uma diferença de cinco ordens de grandeza. O mesmo não acontece para o $\mathrm{Al}$, cujo valor do $k_{\text {eff }}$ está acima do seu valor $k_{0}\left(2 \times 10^{-3}\right)$, porém tem ordem de grandeza semelhante. Tewari et al. [1993], que estudaram a macrossegregação de soluto em ligas de $\mathrm{Pb}-\mathrm{Sn}$, reafirmaram que, quando o sistema se aproxima de uma morfologia dendrítica, ocorre um aumento no coeficiente efetivo de partição, diminuindo a macrossegregação. Isto pode explicar os valores de $k_{\text {eff }}$ acima do respectivo $k_{\circ}$ para o Fe e Cu, visto que, para a velocidade de extração do molde de $110 \mu \mathrm{m} / \mathrm{s}$, foram observadas fortes indicações de estrutura dendrítica. No caso do Al, o mesmo efeito foi observado, mas com menor intensidade. Nota-se que o seu valor de $k_{\text {eff }}$ aumentou apenas uma ordem de grandeza em relação ao $\mathrm{k}_{0}$. Isto pode ser explicado 
pelo fato de que a velocidade correspondente para o $\mathrm{K}_{\text {eff }}$ do $\mathrm{Al}$ foi inferior $(\mathrm{V}=20$ $\mu \mathrm{m} / \mathrm{s})$ às velocidades para o Fe e Cu (V = $110 \mu \mathrm{m} / \mathrm{s})$, resultando em uma macrossegregação menos intensa.

\subsubsection{Efeito da Concentração Inicial da Matéria Prima}

Neste subitem será discutido o efeito da concentração inicial de silício sobre o refino mantendo-se constante a velocidade de extração do molde. Dois tipos de matéria-prima foram utilizados nos ensaios deste trabalho: o silício de grau metalúrgico (SiGM), tal qual recebido da indústria, e o silício previamente refinado (SiR). De forma geral, os perfis de concentração para ambos os ensaios apresentam valores de concentração abaixo do limite de detecção do ICP para ambas as matérias primas para a maioria dos elementos. Isto pode ser observado na metade inicial do lingote principalmente para os elementos $\mathrm{Fe}, \mathrm{Al}, \mathrm{Ti}, \mathrm{Mn}, \mathrm{Cr}, \mathrm{Ni}$ e $\mathrm{Cu}$.

Observa-se que a diferença entre os perfis de concentração para as duas matérias primas é mais notória para as maiores velocidades de extração, onde o refino é menor para o SiGM (ver Figuras 18a a 28b). Porém, quando se analisa os perfis de concentração dos ensaios GM-05 e PR-05, que possuem melhor refino, nota-se que, em uma grande região destes dois lingotes, o nível de refino foi o mesmo. Isto ressalta a eficácia da solidificação direcional do tipo Bridgman como processo de refino mesmo para materiais com altos níveis de impurezas. 
CAPÍTULO 7

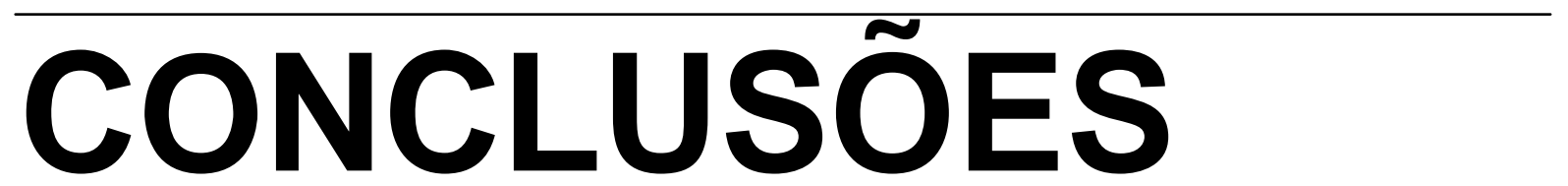




\subsection{CONCLUSÕES}

Com base nas discussões realizadas anteriormente, pode-se concluir que:

1) Os perfis de concentração para a maioria dos elementos presentes no lingote de silício obtido por solidificação direcional controlada mostram um aumento de concentração da base para o topo do lingote, indicando um padrão de macrossegregação consistente com a existência de mistura no líquido durante a solidificação.

2) As regiões da base e centro dos lingotes apresentam um nível de impurezas menor do que o silício introduzido como matéria-prima, revelando um efeito de refino durante a solidificação direcional controlada.

3) A macrossegregação do fósforo ao longo dos lingotes obtidos, bem como o efeito de refino observado nas regiões da base e central destes lingotes, não são significativos, o que pode ser explicado pelo coeficiente de partição de soluto do fósforo ser muito maior do que os coeficientes para os outros elementos contidos no silício.

4) As evidências termodinâmicas de que o cálcio pode sofrer oxidação e volatilização durante os ensaios conduzidos no presente trabalho explicam a diferença entre o padrão de macrossegregação do cálcio e os padrões da maioria dos outros elementos estudados no presente trabalho.

5) A macroestrutura dos lingotes obtidos por solidificação direcional controlada apresenta, na sua maioria, grãos colunares orientados aproximadamente na direção paralela ao da direção de extração do molde.

6) Os grãos colunares observados nos lingotes mostram, junto à parede do molde, um desvio em relação à direção de extração, indicando gradientes de temperatura na direção radial.

7) Um aumento da velocidade de extração do molde resulta em refino de tamanho dos grãos colunares observados nos lingotes. 
8) A utilização de uma base de cobre refrigerada em lugar de uma base isolante térmica resulta em um refino de tamanho dos grãos próximos à base dos lingotes.

9) A diminuição da velocidade de extração do molde diminui a quantidade de precipitados intermetálicos na região da base e central dos lingotes até causar o completo desaparecimento destes intermetálicos nas velocidades de $10 \mu \mathrm{m} / \mathrm{s}$ e $5 \mu \mathrm{m} / \mathrm{s}$ para o silício grau metalúrgico (SiGM) e refinado previamente $(\mathrm{SiR})$, respectivamente.

10)O desaparecimento dos precipitados intermetálicos na base e na região central dos lingotes causada pela diminuição da velocidade de extração do molde para valores abaixo de aproximadamente $10 \mu \mathrm{m} / \mathrm{s}$ indica a transição de uma morfologia de interface sólido-líquido celular/dendrítica para plana, como previsto pela teoria do super-resfriamento constitucional.

11)O silício de grau metalúrgico contendo uma adição de 3\% de germânio apresentou uma estrutura dendrítica quando a solidificação ocorreu sem controle em um tubo de quartzo de $8 \mathrm{~mm}$ de diâmetro; entretanto, não se observou a estrutura dendrítica, indicando uma interface plana, quando a solidificação, agora controlada, ocorreu a uma velocidade de extração de 5 $\mu \mathrm{m} / \mathrm{s}$.

12)A diminuição da velocidade de extração do molde na faixa de $110 \mu \mathrm{m} / \mathrm{s}$ a $5 \mu \mathrm{m} / \mathrm{s}$ aumenta a macrossegregação para maioria dos elementos, resultando em um aumento do teor de impurezas no topo e em uma diminuição do teor de impurezas na base e na região central dos lingotes obtidos, possibilitando um maior refino do silício inicial.

13)A solidificação direcional controlada de um silício inicial de grau metalúrgico (SiGM) em forno tipo Bridgman nas velocidades de $5 \mu \mathrm{m} / \mathrm{s}$ e $10 \mu \mathrm{m} / \mathrm{s}$ resultou em lingotes cujas regiões da base e central apresentaram teores de $\mathrm{Fe}, \mathrm{Al}, \mathrm{Ti}$ e $\mathrm{Cr}$ tão reduzidos quanto os encontrados no silício que alimenta a última etapa de solidificação direcional para obtenção do silício grau solar [Sarti e Einhaus, 2002]. 
14)A solidificação direcional controlada de um silício inicial de grau metalúrgico previamente refinado por lixiviação $(\mathrm{SiR})$ em forno do tipo Bridgmann em todas as velocidades estudadas resultou em lingotes cujas regiões da base e central apresentaram teores de impurezas de $\mathrm{Fe}, \mathrm{Al}, \mathrm{Ti}$ e Cr tão reduzidos quanto os encontrados no silício que alimenta a última etapa de solidificação direcional para obtenção do silício grau solar [Sarti e Einhaus, 2002]. 


\subsection{REFERÊNCIAS BIBLIOGRÁFICAS}

AMERICAN SOCIETY FOR METALS INTERNATIONAL HANDBOOK COMMITTEE ASM HANDBOOK - Metals Park, Asm, 1988.

Anuário ABRAFE, Associação Brasileira de Produtores de Ferro-Ligas, 2004.

BATHEY, B. R., CRETELLA, M. C. - Review: Solar-Grade Silicon - Journal of Materials Science, Volume 17, p 3077 - 3096, 1982.

BOLZAN, V.H.; MEI, P.R.; GARCIA, A.; CAMPOS FILHO, M.P., - Solidificação Unidirecional de Silício para Células Solares - Anais do VI CBECIMAT, PUC, RJ p. 351-354, 1984.

BOGAERTS, A.; GIJBELS, R. - New Developments and Applications in GDMS Fresenius Journal Analytical Chemistry, Volume 364, p. 367-375, 1999.

BRAGA, A. F. B. - Estudo do Potencial da Técnica de Fusão por Feixe de Elétrons para Purificação de Silício Grau Metalúrgico - Tese de Doutorado, UNICAMP, 1997.

BURTON, J.A.; PRIM, R.C.; SLICHTER, W.P. - The Distribution of Solute in Crystals From the Melt. Part I: Theoretical - Journal of Chemical Physics, Volume 21, p. 1987-1990, 1953.

CHALMERS, B. - Principles of Solidification - John Wiley \& Sons, New York, 1964.

CISZEK, T.F; WANG, T. H.; PAGE, M. R.; MENNA, P.; BAUER, R. E.; GOOD, E. A.; LANDRY, M. D. - Alternative Solar-Grade Silicon Feedstock Aproaches - NCPV Program Review Meeting Lakewood, Colorado, p.14-17, 2001.

COLE, G. S.; WINEGARD, W.C.; - Transition From Plane to Celular Interface in Solidifying Tin-Lead-Antimony Alloys -Journal of the Institute of Metals OF METALS Volume 92 pp: 322, 1964.

CRANK, J. - Free and moving boundary problems - Oxford, Oxford University Press, 1984.

DEAN, F.V.; KERR, J.R.; HELLAWELL, A. - Factors Affecting the Solute Distribution During the Normal Freezing os Lead-Antimony Alloys - Journal of the Institute of Metals, Volume 90, p. 234-237, 1961-62.

EARTH POLICY INSTITUTE. EUA. Apresenta dados referentes a produção e comércio de minérios e afins. Disponível em: <http://www.earth-policy.org>. Acesso em: 11/08/2006

Enciclopédia Tecnológica Planetarium, Planetarium, Roma, 1974. 
ENERGY INFORMATION ADMINISTRATION. EUA. Apresenta informações sobre geração e comercialização de energia no mundo. Disponível em: <http://www.eia.doe.gov>. Acesso em: 08/11/2006

FAIRES, L.M. - Inductively Coupled Plasma - Metals Handbook, 9th edition, ASM, p. 31, Volume 10, 1988.

FAVIER, J.J. - Recent Advances in Bridgman Growth Modelling and Fluid Flow Journal of Crystal Growth, Volume 99, p.18-29, 1990.

FERREIRA NETO, J.B. - Estudo termodinâmico do comportamento das impurezas alumínio e cálcio contidas no silício em contato com escórias do sistema CaO-SiO2- $\mathrm{Al}_{2} \mathrm{O}_{3}$. Dissertação (Mestrado em Engenharia) - Escola Politécnica/Departamento de Engenharia Metalúrgica \& Materiais, Universidade de São Paulo, 1991. 142p.

FERREIRA NETO, J.B.; BENEDUCE NETO, F. - Equilíbrio metal/escória para refino de silício em relação às impurezas $\mathrm{Ca}$ e $\mathrm{Al}$ - Anais $50^{\circ}$ Congresso Anual da ABM, 1995, p. 4-15.

FERREIRA NETO, J.B.; NOGUEIRA, P.F.; KASHIWARA, J.J.; CRISTO, S.C.; RODRIGUES, D.; PINTO, E.C.O. - Refining and characterization of silicon for the chemical industry - Proceedings of the Silicon for the chemical industry IV Conference, Geiranger, Norway, 1998.

FLEMINGS, M.C. - Solidification Processing - McGraw-Hill, New York, 1974.

GARANDET, J.P.; FAVIER, J.J.; CAMEL, D. - Segregation phenomena in crystal growth from the melt - Handbook of Crystal Growth, Volume 2, Elsevier Science, 1994.

GARCIA, A. - Solidificação, Fundamentos e Aplicações - Editora da UNICAMP, Campinas, 2001.

HELLAWELL, H. - Complete Segregation by Directional Freezing - Transactions of Metallurgical Society of AIME, Volume 233, p. 1516-1519, 1965

IKEDA, T.; MAEDA, M. - Purification of Metallurgical Silicon for Solar Grade Silicon by Electron Beam Button Melting - ISIJ International, Volume 32, no 5, p. 635 - 642, 1992.

INDEX MUNDI. EUA. Apresenta informações geográficas de todas as regiões do mundo. Disponível em: <www.indexmundi.com>. Acesso em: 08/11/2006

INOUE, S.; SAKA, T.; Elemental Analysis of Powders by Glow Discharge Mass Spectrometry - Analytica Chimica Acta, Volume 355, p. 165-171, 1999.

JACKSON, K. A., and HUNT, J. D. - Transparent compounds that freeze like metals - Acta Metallurgica, Volume 13, p. 1212-1215, 1965. 
JAIN, G. C.; CHAKRAVARTY, B. C.; PRASAD, A. - Effect of Annealing on Resistivity and Photoconductivity of Solar Grade Polycrystaline Silicon and on Solar Cell Performance - Jounal of Applyed Physics, Volume 52, p. 3700 - 3701 , 1981.

KHATTAK, C.P.; JOYCE, D.B.; SCHIMID, F. - A Simple Process to Remove Boron From Metallurgical Grade Silicon - Solar Energy Materials \& Solar Cells, Volume 74, p. 77-89, 2002.

KURZ, W.; FISHER, D.J. - Fundamentals of Solidification, Aedermannsdorf, Trans Tech Publications Ltd., 1989.

MADEIRA, F.A.; FONSECA, C. G.; FRANCO, D. S.; ARAÚJO, S.; ALMEIDA, T. B.; BRANCO, J. R. T.; DINIZ, A. S. A. C.; - Desenvolvimento de Insumos para Utilização na Fabricação de Células Solares - Anais do II CITENEL - 2003

MARGARIA, T. - Influence of Cooling on Silicon Structure - Proceedings of the Silicon for the chemical industry III Conference, Sandefjord, Norway, 1996.

MARTORANO, M. A., Solidificação de Metais e Ligas. Notas de Aula. 2005

MOEHLECKE, A.; ZANESCO, I. - Produção de Módulos Fotovoltaicos com Tecnologia Nacional - Centro Brasileiro de Energia Solar Fotovoltaica, PUC-RS, 2007.

MORITA, K.; MIKI, T. - Thermodynamics of Solar-Grade-Silicon Refining Intermetalics, Volume 11, p. 1111 - 1117, 2003.

MÜLLER, G. - Convection and Inhomogeneities in Crystal Growth from the Melt, New York, Springer-Verlag, 1988.

MURRAY, G.T.; LOGRASSO, T.A. - Preparation and characterization of pure metals, In: AMERICAN SOCIETY FOR METALS INTERNATIONAL. Metals Handbook $10^{\text {th }}$ edition. Metals Park, ASM, Volume 2, p.1094, 1990.

NATIONAL CENTER FOR PHOTOVOLTAICS. Apresenta dados referentes à energia solar ao redor do mundo. Disponível em: <http://www.nrel.gov/>. Acesso em: 17/10/2006.

OJHA, S. N.; DING, G.; LU, Y.; REYE, J.; TEWARI, S.N. - Macrosegregation Caused by Thermosolutal Convection During Directional Solidification of PbSb Alloys - Metallurgical and Materials Transactions A, Volume 30A, p, 2167-2171, 1999.

PIRES, J. C. S.; OTUBO, J ; BRAGA, A. F. B., MEI, P.R. - Perfil de Impurezas em Amostra de Silício Policristalino Purificado em Forno de Fusão por Feixe de Elétrons - Anais do 55 Congresso Anual da ABM, Rio de Janeiro, RJ, p. 84 - 93, 2000.

PIZZINI, S. - Solar Grade Silicon as a Potential Candidate Material Low-Cost Terrestrials Solar Cells - Solar Energy Materials, № 6, p 253 - 297, 1982. 
RADOJEVIC, V.; VALCIC, A.; NIKOLIC, S. - Interface Shape and Distribution of Solute During Vertical Bridgman Growth of Al-Cu Alloy - Materials Letters Volume 52, p. 248-254, 2002.

REVEL, G.; PASTOL, J. L.; HANIA, D.; HUYNH, N. D. - Etude de la Solidification Directionnelle en Crueset du Silicium en Vue dún Usage Solaire - Revue de Physique Appliquée, Volume 22, p. 519-528, 1987.

SARTI, D.; EINHAUS, R. - Silicon Feedstock for the Multi-Crystalline Photovoltaic Industry - Solar Energy Materials \& Solar Cells, Volume 72, p 27-40, 2002.

SCHEI, A. - Metallurgical Production of High Purity Silicon - INFACON 86 Proceedings, p 389-398, 1986.

SCHEI, A.; TUSET, J. K.; TVEIT, H. - Production of High Silicon Alloys - Tapir Forlag, Trondhein, 1998.

SCHEIL, E. - Über die Eutektische Kristallisation - Zeitschrift für Metallkunde, Volume 34, p. 70-72, 1942.

SCHIEVENBUSCH, A.; ZIMMERMANN, G.; LÜ, X. L. - Directional Solidification of Near-Azeotropic Cumn-Alloys - A Model System for the Investigation of Morphologie and Segregation Phenomena - ISIJ International, Volume 35, p. 618$623,1995 b$.

SMITH, V.G.; TILLER, W.A.; RUTTER, J.W. - A Mathematical Analysis of Solute Redistribution During Solidification - Canadian Journal of Physics, Volume 33, p. 723-745, 1955.

SUZUKI, K., KUMAGAI, T. e SANO, N. - Removal of Boron from metallurgical grade silicon by applying the plasma treatment - ISIJ International, Volume 32, no 5, p. $630-634,1992$.

TEWARI, S. N.; SHAH, R.; CHOPRA, M. A. - Thermosolutal Convectionand Macrosegregation Caused by Solute Rejection at Cell/Dendrite Tips Mettalurgical Transactions A, Volume 24A, p. 1661-1669, 1993.

TILLER, W.A.; JACKSON, K.A.; RUTTER, J.W.; CHALMERS, B. - The Redistribution of Solute Atoms During the Solidification of Metals - Acta Metallurgica, Volume 1, p. 428-437, 1953.

TRUNZO, J. E. - Silicon Metal: Changing Times for Consumers and Suppliers Ryan's Notes Ferroalloy Conference, Boca Raton, Flórida, 20-22 de Outubro de 1996.

U. S. GEOLOGICAL SURVEY. EUA. United States Department of the Interior. Apresenta informações sobre produção mundial de minérios e afins. Disponível em: <www.usgs.gov/>. Acesso em: 08/11/2006. 
WAGATSUMA, K.; SAKA, T.; YAMAGUCHI, M; ITO, K. - Comparative Investigation on the Characteristics of Glow Discharge Plasma Using Glow Discharge Mass Spectrometry and Glow Discharge Optical Emission Spectrometry - Journal Analytical Atomic Spectrometry, Volume 17, p. 1359-1362, 2002.

WALTON, D.; TILLER, W. A.; RUTTER, J. W.; WINEGARD, W. C. - Instability of a Smooth Solid-Liquid Interface During Solidification - Journal of Metals, p.10231026, Setembro de 1955.

WEINBERG, F. - Solute Distributions in Directionally Solidified Rods of Dilute Sn-Ag Alloys - Transactions of Metallurgical Society of AIME, Volume 227, p. 231238, 1963.

WOLDITSCH, P.; KOCH, W. - Solar Grade Silicon Feedstock Supply for PV Industry - Solar Energy Materials \& Solar Cells, Volume 72, p. 11-26, 2002.

YUGE, N.; BABA, H.; SAKAGUSHI, Y.; NISHIKAWA, K.; TERASHIMA, H. ARATANI, F. - Purification of Metallurgical Silicon up to Solar Grade - Solar Energy Materials and Solar Cells, nº 34, p. 243 - 250, 1994

YUGE, N.; SAKAGUCHI, Y.; TERASHIMA, H.; ARATANI, F. J. - Purification of Silicon by Directional Solidification - Journal of the Japan Institute of Metals, Volume 61, p. 1094-1100, 1997.

YUGE, N.; ABE, M.; HANAZAWA, K; BABA, H; NAKAMURA, N; KATO, Y; SAKAGUCHI, Y. - Purification of Metallurgical Silicon up to Solar Grade Progress in Photovoltaics: Research and Aplications, Volume 9, p. 203-209, 2001.

YUE, A.S.; CLARK, J.B. - Directional Freezing of Magnesium Alloys Transactions of Metallurgical Society of AIME, Volume 218, p. 55-58, 1960.

ZIMMERMANN, G.; SCHIEVENBUSCH, A.; STEHLE, M.A. - Macrosegregation in Directionally Solidified Copper-Manganese Alloys with Compositions Near the Melting Point Minimum - Zeitschrift fur Metallkunde, Volume 87, p. 629-633, 1996.

ZULEHNER, W. - Historical Overview of Silicon Crystal Pulling Development Materials Science and Engineering B, Volume 73, p. 7-15, 2000. 


\section{ANEXO}

Propriedades físicas e composição química dos cadinhos de grafita e dos tubos de quartzo utilizados na fusão e solidificação de silício.

Tabela 1A - Propriedades físicas dos cadinhos de grafita.

\begin{tabular}{|c|c|}
\hline Propriedades Médias Típicas & Valores \\
\hline $\begin{array}{c}\text { Densidade } \\
\left(\mathrm{g} / \mathrm{cm}^{3}\right) \\
\end{array}$ & 1,80 \\
\hline $\begin{array}{c}\text { Resistência Específica } \\
(\mathrm{u} \Omega \mathrm{m})\end{array}$ & 1,40 \\
\hline $\begin{array}{l}\text { Tensão de Flexão } \\
\left(\mathrm{kgf} / \mathrm{cm}^{2}\right)\end{array}$ & 600 \\
\hline $\begin{array}{c}\text { Tensão de Compressão } \\
\left(\mathrm{kgf} / \mathrm{cm}^{2}\right)\end{array}$ & 1.000 \\
\hline $\begin{array}{l}\text { Limite de Resistência à Tração } \\
\left(\mathrm{kgf} / \mathrm{cm}^{2}\right)\end{array}$ & 350 \\
\hline $\begin{array}{l}\text { Módulo de Young } \\
\left(\mathrm{kgf} / \mathrm{mm}^{2}\right)\end{array}$ & 1.100 \\
\hline $\begin{array}{c}\text { Dureza } \\
(\text { Shore D) } \\
\end{array}$ & 53 \\
\hline $\begin{array}{c}\text { Coeficiente de Expansão Térmica } \\
20^{\circ} \mathrm{C}-100^{\circ} \mathrm{C} \\
\left(10^{-6} / \stackrel{\circ}{ } \mathrm{C}\right)\end{array}$ & 4,70 \\
\hline $\begin{array}{l}\text { Tamanho Máximo de Grão } \\
\text { (microns) }\end{array}$ & $15,0 \mu \mathrm{m}$ \\
\hline $\begin{array}{c}\text { Condutibilidade Térmica } \\
\left.\text { (kcal / } \mathrm{mh}^{\circ} \mathrm{C}\right)\end{array}$ & 80 \\
\hline $\begin{array}{c}\text { Porosidade } \\
(\%)\end{array}$ & 14 \\
\hline
\end{tabular}

Fonte: Consulta à empresa fornecedora (Egyper Carbon LTDA)

Tabela 2A - Composição química dos cadinhos de grafita.

\begin{tabular}{|c|c|c|c|c|c|c|c|c|c|}
\hline $\mathbf{S i}$ & $\mathbf{F e}$ & $\mathbf{T i}$ & $\mathbf{B}$ & $\mathbf{V}$ & $\mathbf{C a}$ & $\mathbf{~ M g}$ & $\mathbf{N i}$ & $\mathbf{A l}$ & Total \\
\hline 3,5 & 2,6 & $<0,1$ & $<0,1$ & - & 3,8 & 0,2 & - & 0,2 & $<100 \mathrm{ppm}$ \\
\hline \multicolumn{8}{|c|}{ |conte: Consulta à empresa fornecedora (Egyper Carbon LTDA) }
\end{tabular}

Nota: Os métodos utilizados para a obtenção das propriedades são definidos pela norma da ASTM 
Tabela 3A - Composição química dos tubos de quartzo.

\begin{tabular}{|c|c|}
\hline Elemento & Concentração (ppm) \\
\hline $\mathrm{Al}$ & 0,3 \\
\hline $\mathrm{Fe}$ & 0,6 \\
\hline $\mathrm{Ca}$ & 1,5 \\
\hline $\mathrm{Ti}$ & 0,2 \\
\hline $\mathrm{Na}$ & 0,2 \\
\hline $\mathrm{K}$ & 0,2 \\
\hline $\mathrm{Li}$ & 0,1 \\
\hline $\mathrm{Mg}$ & $<0,05$ \\
\hline $\mathrm{Cu}$ & $<0,05$ \\
\hline $\mathrm{Cr}$ & \\
\hline
\end{tabular}

Fonte: Consulta à empresa fornecedora (Quarzschmelze IImenau - QSIL) 